UNIVERSIDADE DE SÃO PAULO

FACULDADE DE FILOSOFIA, LETRAS E CIÊNCIAS HUMANAS

DEPARTAMENTO DE HISTÓRIA

PROGRAMA DE PÓS-GRADUAÇÃO EM HISTÓRIA ECONÔMICA

MARTINHO CAMARGO MILANI

Percival Farquhar, um homem quase sem nenhum caráter entre oligarcas e nacionalistas de muita saúde (1898-1952)

ORIENTADOR: PROF.DR. LINCOLN FERREIRA SECCO

SÃO PAULO

2017

VERSÃO CORRIGIDA 
LOMBADA

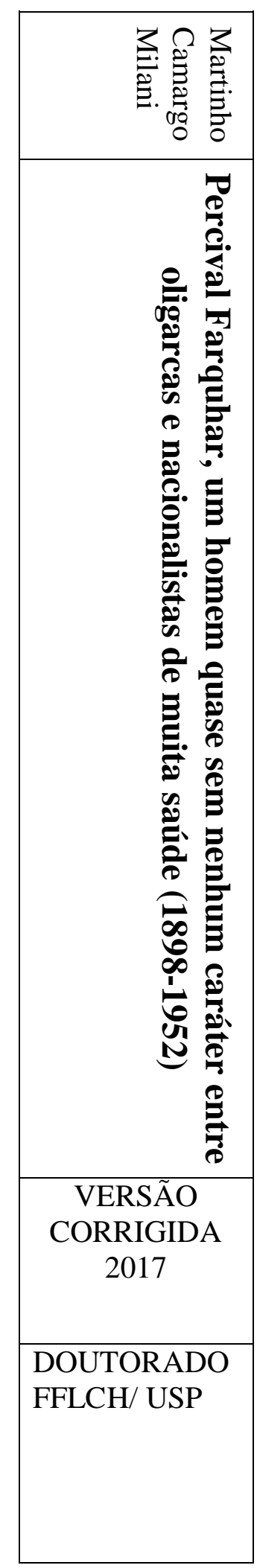


MARTINHO CAMARGO MILANI

\title{
Percival Farquhar, um homem quase sem nenhum caráter entre oligarcas e nacionalistas de muita saúde (1898-1952)
}

\author{
Versão Corrigida
}

Tese de Doutorado apresentada ao Programa de Pós-graduação em História Econômica da Faculdade de Filosofia, Letras e Ciências Humanas da Universidade de São Paulo, como parte dos requisitos para a obtenção do título de Doutor em História.

Orientador: Prof.Dr. Lincoln Ferreira Secco

SÃO PAULO 
Autorizo a reprodução e divulgação total ou parcial deste trabalho, por qualquer meio, convencional ou eletrônico, para fins de estudo e pesquisa, desde que citada a fonte. 
MILANI, Martinho Camargo. Percival Farquhar, um homem quase sem nenhum caráter entre oligarcas e nacionalistas de muita saúde (1898-1952). Tese apresentada à Faculdade de Filosofia, Letras e Ciências Humanas da Universidade de São Paulo para a obtenção do título de Doutor em História Econômica.

Aprovado com Recomendação para Publicação em: 05/04/2017

\section{Banca Examinadora}

Presidente: Prof.Dr.Lincoln Secco - FFLCH-USP

Membros da Banca:

Prof.Dr.Wilson Nascimento Barbosa - FFLCH-USP

Prof.Dr. Manoel Fernandes de Sousa Neto - FFLCH-USP

Prof. Marcos Tadeu Del Roio - Unesp Marília

Prof. Dr. José Mao Jr. - IFSP 


\section{AGRADECIMENTOS}

O processo de escrita da História é silencioso e solitário. Porém, algumas pessoas e instituições são essenciais para o trabalho de reconstrução do passado. Gostaria de agradecê-los neste espaço.

Em primeiro lugar ao meu antigo colega de faculdade, depois brilhante pesquisador e hoje renomado Professor Livre Docente em História pela USP, Lincoln Secco. Acreditar e confiar num velho companheiro sem muita experiência acadêmica e dar total liberdade para a produção da tese muito me engrandeceu. Sinto-me honrado de ter sido orientado por um dos maiores historiadores do país e o que é melhor, comprometido com as obrigações acadêmicas, didáticas e pra com a realidade social e econômica do país.

Aos ilustres professores Wilson do Nascimento Barbosa, José Mao Jr e Alexandre Macchione Saes, todos eles essenciais para a delimitação do tema, correção de caminhos e análises da mais densa profundidade para a construção desta tese. Para o professor Manoel Fernandes de Sousa Neto fica um recado de que os ventos do norte para estas bandas movem moinhos. Devo a ele a sugestão de inversão da ordem e o defunto-autor Farquhar.

Um agradecimento especial à professora Carmen Lícia Palazzo que mesmo sem me conhecer pessoalmente foi extremamente solícita e educada, concedendo-me informações relevantíssimas para a tese.

Para todo o pessoal do Grupo de Estudos Marxistas (G Marx) do qual participei das reuniões ativamente entre 2009 e 2013 e da Revista Mouro, os dois com seu caráter interdisciplinar e com dezenas de colegas de profundo conhecimento teórico, colaboraram muito na minha formação.

Aos funcionários da Pós Gradução da História-USP, sempre pacientes. Em especial ao Nelson, que nas horas difíceis terminou por resolver tudo a contento.

Para a CAPES, por ter me concedido uma bolsa de estudos entre junho de 2013 a dezembro de 2016. Com a bolsa pude me dedicar a concluir esta tese. Sem a mesma, certamente não a teria concluído.

Agradeço a minha família e, em especial a minha irmã Maria Stella, crescemos juntos, discordamos muito, mas nos momentos cruciais ela sempre esteve ao meu lado. Gratidão sempre. 
Ao meu pai Leonardo da Vinci Milani e a minha mãe Dinah de Camargo Milani que me acompanharam nesta longa jornada e estiveram presentes no momento decisivo, mesmo aos 90 anos.

Por último, e mais importante, à minha esposa, Luana Araujo Viana Milani. Coincidências do destino, começamos a namorar no mesmo mês do início deste trabalho: julho de 2012. Nos dois casos as dificuldades foram grandes, mas a certeza de que havia escolhido corretamente o caminho me fez continuar. Foram 4 anos e meio de batalhas e conquistas. Sempre teve paciência comigo, respeitando as intermináveis horas de pesquisa e escrita, afinal a história é árdua. Obrigado meu amor.

E que os frutos perdurem para sempre.

Sorocaba, 30 de Maio de 2017 


\title{
RESUMO
}

\author{
MILANI, Martinho Camargo. Percival Farquhar, um homem quase sem \\ nenhum caráter entre oligarcas e nacionalistas de muita saúde (1898-1952). Tese \\ (Doutorado) Faculdade de Filosofia, Letras e Ciências Humanas. Departamento de \\ História Econômica. Universidade de São Paulo.
}

A presente tese procurou retratar o período da República Velha entre 1898 e 1931. Entender o papel da dependência econômica do Brasil para com um produto: o café; e os constantes endividamentos realizados pela nação para cobrir os constantes rombos orçamentários.

Deu-se atenção especial aos empréstimos tomados com instituições estrangeiras, em especial europeias, os denominados funding loans (1898, 1914, 1931).

Tais condições econômico-financeiras foram combatidas com as políticas recessivas da corrente Metalista. Saneado o país, novos períodos Papelistas se instalavam na economia, metaforicamente como o mito de Sísifo.

Nesses ciclos intermináveis, o Brasil passava por profundas transformações socioeconômicas decorrentes da adoção do regime republicano, da abolição da escravidão e da industrialização e urbanização crescentes.

Foi nesse contexto que um empresário norte-americano, Percival Farquhar tornou-se um dos maiores empresários da história do Brasil. Construiu um imenso império industrial em atividades como ferrovias, portos, serrarias, frigoríficos e hotéis ( entre outras). Não sem sofrer profunda oposição de nacionalistas e agraristas.

Procurou-se por último, demonstrar por meio dos relatórios do ministério da Fazenda entre 1898 e 1915 que, ao contrário do pretendido, foram as políticas Metalistas uma das grandes responsáveis pela industrialização do Brasil. Contra a própria vontade de seus ideólogos.

Num Brasil em convulsão e transformação completa as classes dominantes se acomodam em velhos estofados, trocando apenas o couro embrutecido pelo tempo.

Palavras-chave: Economia na República Velha - Funding Loan - Percival Farquhar - Papelistas e Metalistas - Industrialização 


\begin{abstract}
MILANI, Martinho Camargo. Percival Farquhar, a man with almost no character among oligarchs and nationalists of great health (1898-1952). Tese (Doutorado) Faculdade de Filosofia, Letras e Ciências Humanas. Departamento de História Econômica. Universidade de São Paulo.
\end{abstract}

The present thesis sought to portray the period of the Old Republic between 1898 and 1931. Understand the role of Brazil's economic dependence on a product: coffee; And the constant indebtedness carried out by the nation to cover the constant budgetary rhythms.

Special attention was given to borrowing from foreign institutions, especially European institutions, the so-called funding loans $(1898,1914,1931)$.

Such economic-financial conditions were countered with the recessive policies of the Metalist chain. Once the country was rediscovered, new periods of time were established in the economy, metaphorically as the myth of Sisyphus.

In these interminable cycles, Brazil underwent profound socioeconomic transformations resulting from the adoption of the republican regime, the abolition of slavery and increasing industrialization and urbanization.

It was in this context that an American businessman, Percival Farquhar became one of the greatest entrepreneurs in Brazilian history. He built an immense industrial empire in activities such as railroads, ports, sawmills, refrigerators and hotels (among others). Not without deep opposition from nationalists and agrarians.

Finally, it was tried to demonstrate through the reports of the Ministry of Finance between 1898 and 1915 that, contrary to what was intended, Metalist policies were one of the great responsible for the industrialization of Brazil. Against the will of its ideologues.

In Brazil in convulsion and complete transformation the ruling classes settle in old upholstery, exchanging only the weathered leather.

Keywords: Economic of Old Republic - Funding Loan - Percival Farquhar Papermakers and Metalworkers - Industrialization 


\section{LISTA DE TABELAS}

Tabela 1 - Distribuição Étnica da População Brasileira 102

Tabela 2 - Distribuição da População Escrava Brasileira 103

Tabela 3 - Movimento de Imigração 104

Tabela 4 - População das Capitais Brasileiras em 1872 e 1920108

Tabela 5 - População das Cidades Brasileiras em 1872 e 1920109

Tabela 6 - Estatísticas do Café. Valor Médio da Saca no Merc. Intern. 215

Tabela 7 - Dívida Externa (milhares de dólares) 218

Tabela 8 - Receitas de 1899 a $1901 \quad 231$

Tabela 9 - Despesas de 1899 a 1901

Tabela 10 - Relatório das Exportações 240

Tabela 11 - O papel-moeda em circulação 242 


\section{MAPAS}

Mapa 1 - Ferrovia Madeira-Mamoré

Fonte: Mapa da Estrada de Ferro Madeira Mamoré de 1912. Foto: Fernando Rebouças. Acesso em 24 de novembro de 2016. Disponível em <http://werterdejesus.blogspot.com.br/2012/04/transporte-ferroviario-nobrasil.html>

Mapa 2 - Ferrovia São Paulo-Rio Grande

Fonte: Lloyd's Greater Britain Publishing Company, Ltd - Lloyd's Greater Britain Publishing Company, Ltd. Pag. 228 da Obra: "Impressões do Brazil no Seculo Vinte", editada em 1913 e impressa na Inglaterra por Lloyd's Greater Britain Publishing Company, Ltd.

Mapa 3 - Geopolítica da América do Sul. Golbery do C. e Silva

Fonte: COSTA, Wanderley Messias da. Políticas territoriais brasileiras no contexto da integração sul-americana. Texto apresentado durante o Congresso Brasil-Portugal Ano 2000 (Lisboa, 16-18/6/1999), sob responsabilidade da Comissão Bilateral Executiva para as Comemorações do V Centenário da Viagem de Pedro Álvares Cabral. 


\section{SUMÁRIO}

INTRODUÇÃO

CAPÍTULO 1 - PERCIVAL FARQUHAR

1.1. O Modelo de Negócios de Percival Farquhar 11

1.2. Percival Farquhar Além do Brasil 12

$\begin{array}{ll}\text { 1.2.1. Cuba } & 12\end{array}$

$\begin{array}{ll}\text { 1.2.2. Guatemala } & 14\end{array}$

$\begin{array}{ll}\text { 1.3.3. União Soviética } & 14\end{array}$

1.3.4. América do Sul 15

1.4. A Primeira Fase Brasileira 16

1.4.1. Rio de Janeiro 16

$\begin{array}{ll}\text { 1.4.2. Salvador } & 19\end{array}$

$\begin{array}{ll}\text { 1.4.3. Belém } & 19\end{array}$

1.4.4. A Ferrovia do Diabo - Madeira Mamoré 21

1.4.5. Sul do Brasil 23

1.4.6. Outros Projetos $\quad 27$

1.5. A Derrocada de Farquhar 30

1.6. O Primeiro Retorno ( 1919-1942) 34

1.7. A Última Esperança ( 1944-1952) 35

CAPÍTULO 2 - REPÚBLICA VELHA ( 1889 - 1914) 38

2.1.Breviário Político 40

2.1.1.Prudente de Moraes (1894-1898)

$\begin{array}{ll}\text { 2.1.2. Campos Salles (1898-1902) } & 47\end{array}$

2.1.3.Rodrigues Alves (1902-1906) 56

2.1.4.Afonso Penna ( 1906-1909) 60

2.1.5.Nilo Peçanha (1909-1910) 61

2.1.6.Hermes da Fonseca (1910-1914) 65 
$\begin{array}{ll}\text { 3.1. Introdução } & 70\end{array}$

3.2. O Primeiro Funding Loan ( 1898)

3.2.1. Crise do Banco Baring $\quad 79$

3.2.2. A negociação brasileira de $1898 \quad 80$

3.2.3. Uma República de Homens

3.3. O segundo Funding Loan ( 1914) 88

3.4. O terceiro Funding Loan (1931) 94

CAPÍTULO 4 - IMPÉRIO DO CAFÉ (1905 a 1914) 99

4.1. População em Movimento 101

4.2. Cidades Novas e Mundo urbano 106

4.3. A Reconstrução das Capitais 110

4.3.1.Rio de Janeiro: o Bota Abaixo 110

4.3.2.Belo Horizonte: Edificar o novo tempo 114

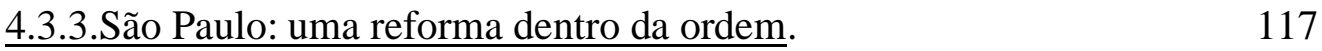

CAPÍTULO 5 - REPÚBLICA VELHA E SEU OCASO ( 1914-1931) 122

5.1.O Direito 122

5.2. O Futebol 129

5.3. As Artes 98

5.4.Breviário Político 136

5.4.1.Wenceslau Braz (1914-1918) 145

A Greve Geral de 1917

Um país em Guerra $\quad 147$

5.4.2.Delfim Moreira ( 1918-1919) 148

5.4.3. Epitacio Pessôa (1919-1922) 150

Um apêndice do Foot-ball 150

Tenentismo 151

5.4.4. Arthur Bernardes ( 1922-1926) 153

5.4.5. Washington Luís ( 1926-1930) 154

A Longa Marcha 154

5.4.6. O Ocaso do Café-com Leite 156 
CAPÍTULO 6 - CONTEXTO MUNDIAL 158

6. 1. Primeiro Cavaleiro: A Conquista 159

6. 2. Segundo Cavaleiro: A Guerra 166

6.2.1. A Guerra contra Todos 166

$\begin{array}{ll}\text { 6.2.2. A Guerra em Si } & 168\end{array}$

6.3. Terceiro Cavaleiro: A Fome. Anda Um Espectro pela Europa 171

6. 4. Quarto Cavaleiro: A morte e a Crise de 1929

CAPÍTULO 7 - ECONOMIA NA REPÚBLICA VELHA

7.1. Ciclos Olímpicos e Econômicos 184

7.2. A Moeda e Seus Percalços 189

7.2.1. A moeda no Brasil 191

$\begin{array}{ll}\text { 7.2.2. Metalistas e Papelistas } & 195\end{array}$

7.2.3 Agraristas e Industrialistas 202

7.2.4. As idas e Vindas Econômicas da República Velha 209

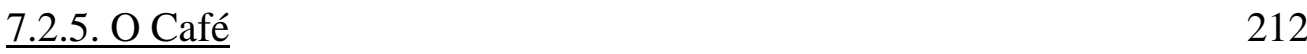

$\begin{array}{ll}\text { 7.2.6. A Dívida Externa } & 217\end{array}$

CAPÍTULO 8 - OS RELATÓRIOS MINISTERIAIS 220

8.1. Joaquim Murtinho 221

8.2. Leopoldo de Bulhões 232

8.3. David Campista 236

8.4. Francisco Salles 244

8.5. Rivadávia da Cunha Corrêa 245

$\begin{array}{ll}\text { 8.6. Pandiá Callógeras } & 248\end{array}$

CONCLUSÃO 253

FONTES PRIMÁRIAS 256

$\begin{array}{ll}\text { BIBLIOGRAFIA } & 258\end{array}$ 


\title{
Introdução
}

\author{
“É a produção que propicia mercados aos produtos." \\ (Lei de Say. Tratado de Economia Política. Jean Baptiste Say. Pág. 137)
}

Walter Benjamin nas "Passagens" elabora a ideia de que o homem tem pressa e esquecimento. O tempo passado é a era da carência - comparado ao presente. $\mathrm{O}$ historiador só é capaz de produzir um instantâneo do que se foi. O filósofo alemão, analisando Baudelaire, relembra um momento em que o poeta, inebriado pela droga, afirma que toda uma noite passada pareceu-lhe um átimo. Somos, segundo Benjamin, como o artista francês, catadores de migalhas, ou de forma mais brilhante:

“Em qualquer época, os vivos descobrem-se no meio dia da História. Espera-se deles que preparem um banquete para o passado. O historiador é o arauto que convida os defuntos à mesa." ( $\mathrm{N} 15,2)$.

Sórdida tarefa esta dos historiadores: dar voz aos que passaram. Tantas são as palavras proferidas, mais ainda as esquecidas.

A presente tese de doutorado procurou estudar dois convidados da Primeira República: Joaquim Murtinho e Percival Farquhar. Primeiro, o ministro das Finanças do início do século $\mathrm{XX}$, posteriormente o empresário estadunidense que veio montar seu império industrial atraído pelas concessões de ferrovias e serviços públicos advindas com o $1^{\circ}$ Funding Loan (1898).

Definiu-se como período inicial da mesma, o ano de 1898 quando Campos Salles assume a Presidência da República do Brasil e conduz Joaquim Murtinho ao Ministério da Fazenda, responsável pelas medidas saneadoras impostas pelo empréstimo internacional. O ano derradeiro deste estudo é o de 1952, data em que

\footnotetext{
${ }^{1}$ BENJAMIN, Walter. Passagens. Belo Horizonte/São Paulo: Editora UFMG/Imprensa Oficial do Estado de São Paulo, 2006. pág. 523
} 
Percival Farquhar, bastante doente, deixa o Brasil pela última vez e repassa a maioria das ações de seu investimento na Acesita para o Banco do Brasil.

A Tese está dividida em 8 Capítulos. Percival Farquhar é o tema central do capítulo inaugural. A organização dos seus negócios, as experiências anteriores em Cuba e Guatemala e o método de estruturação empresarial. A fonte primordial do $8^{\circ}$ capítulo é a história biográfica de Charles Gauld, escrita nos anos 60 e traduzida apenas em 2005 por um motivo desconexo da história econômica do país, estreava então uma minissérie da Rede Globo. Pouco conhecida e repleta de chavões e preconceitos, a vida de Farquhar no Brasil é analisada a partir de seus empreendimentos por aqui e não foram poucos. Apesar das atividades da Acesita perdurarem até 1952, esta tese escolheu o contexto interno da República Velha até o $3^{\circ}$ funding loan como balizamento. Não deixando, é claro de traçar um sucinto painel do último projeto de Farquhar no Brasil. Entender que a presença do americano só possível seja pela política do café-com-leite e suas concessões, ou pelas políticas econômicas Metalistas e sua estabilidade financeira, à custa, é claro, de muita recessão. Este é o caminho percorrido em busca de sentido para o passado.

Num segundo capítulo será apresentado um painel geral da história política e social do Brasil entre os fins do século XIX e o final do governo Hermes da Fonseca. Trata-se do período entre o primeiro funding loan e o posterior remédio amargo adotado por Joaquim Murtinho, que será estendido até o auge e declínio dos negócios de Percival Farquhar no Brasil.

Será seguido pelo terceiro capítulo com o estudo das medidas financeiras adotadas pelo ministro Joaquim Murtinho entre os anos 1898 a 1902. Além do estudo da política econômica do período, pretende-se apresentar um breve relato das principais influências teóricas do ministro e de boa parte das elites econômicas do país. A análise da conjuntura econômica não se encerra em 1902, pois o ciclo de empréstimos, medidas recessivas, novos endividamentos e busca de novas fontes de recursos financeiros se repete mais duas vezes: em 1914 e 1931 com os 2 e $3^{\circ}$ funding loans. Joaquim Murtinho foi homeopata, professor da Politécnica, senador da República, um dos proprietários da Companhia Matte Laranjeira ( uma concessão pública para o monopólio da erva mate que atingiu a irrisória dimensão de 5 milhões de hectares de terra) e, claro, como todo bom senhor de terras no Brasil, um coronel matogrossense. Admirava as obras de Friederich List, Jean Baptiste Say e Herbert Spencer. Com esse cabedal, nada mais justo do que receber o Ministério da Indústria, da Viação e Obras 
Públicas de Prudente de Moraes ( 1894-1898) e depois o Ministério dos Negócios da Fazenda no governo Campos Salles ( 1898-1902). O heroi das finanças públicas saudáveis acreditava que nossa indústria era o sinônimo do atraso e alegava que:

Importamos cereais para não importarmos fósforos: importamos gado para não importarmos sedas. O nosso patriotismo exulta com esta política industrial curiosa: Importamos caro aquilo que podíamos produzir barato e produzimos caro aquilo que podíamos importar barato, fórmula que representa degradação econômica, pois que ela se traduz no emprego dos nossos capitais e do nosso esforço para elevar o preço dos objetos de consumo, tornando a vida cada vez mais dura e mais difícil."2

Liberal neoclássico, ele não via sentido na "indústria artificial", como a de fósforos, em que o Brasil importava tudo, desde o palito, passando pela caixinha embaladora, até o produto químico que produzia a chama. Partidário dos interesses agrários, suas medidas financeiras permitiram, contra seu interesse, um desenvolvimento industrial no país.

A permanência desta visão desmerecedora de nossa economia por parte das classes dominantes da República Velha e de uma pretensa incapacidade competitiva no mercado internacional impressiona. Marx afirma no 18 Brumário que:

Os homens fazem sua própria história, mas não a fazem como querem; não a fazem sob circunstâncias de sua escolha e sim sob aquelas que se defrontam diretamente, legadas e transmitidas pelo passado. A tradição de todas as gerações mortas oprime como um pesadelo o cérebro dos vivos. E justamente quando parecem empenhados em revolucionar-se a si e as coisas, em criar algo que jamais existiu, precisamente nesses períodos de crise revolucionária, os homens conjuram ansiosamente em seu auxílio os espíritos do passado, tomando-lhes emprestado os nomes, os gritos de guerra e as roupagens, a fim de apresentar-se nessa linguagem emprestada. ${ }^{3}$

Quase um século após Joaquim Murtinho, um presidente vociferou serem nossos carros verdadeiras carroças e mais curioso ainda, um jovem economista que estudara as

\footnotetext{
${ }^{2}$ Citado por LUZ, Nícia Vilela. A luta pela industrialização do Brasil. $2^{\mathrm{a}}$ ed. Editora Alfa-Ômega. Brasil. 1978. Pág. 87

${ }^{3}$ MARX, Karl. O 18 brumário de Napoleão Bonaparte. $4^{a}$ ed. Nova Cultural. Coleção 'Os Pensadores'. São Paulo. 1988. Pág. 7
} 
reformas monetárias do início da República e o Encilhamento ( não sem tecer críticas ácidas ao mesmo e sua política emissionista), torna-se um dos artífices do plano de redução do capital circulante, do saneamento das finanças públicas e das privatizações neoliberais do final do século XX no Brasil. O terceiro presidente alagoano de nossa história, Fernando Collor e o economista Gustavo Franco, homens contemporâneos, vestiram-se do passado e tomaram emprestado as palavras do homeopata mágico da República Velha.

No quarto capítulo teremos as grandes transformações sociais e humanas decorrentes do trinômio: fim da escravidão, a riqueza do café e a ascensão do regime republicano. Uma população em movimento e as grandes cidades sendo reconstruídas pelos ideais sanitários e racionais do capitalismo liberal, inspiradas no modelo higienista parisiense. Cidades como São Paulo, Rio de Janeiro e Belo Horizonte, que não foram as únicas a passarem pelas reformas urbanas dos novos tempos, mas por serem elas a sede política e econômica da oligarquia do café-com-leite.

O quinto capítulo inicia com um estudo social. Para isso foram escolhidos três elementos que representam, respectivamente, a alma da sociedade agrária em transição para a burguesa, representada pelo Direito Civil, o grande código das relações capitalistas; o corpo, retratando a presença cada vez maior das camadas populares na sociedade e a necessidade de ao mesmo tempo civilizar e oferecer lazer; e por último, a mente, com uma análise das mudanças culturais do Brasil entre os anos 20 e 30 a partir da obra "O Rei da Vela", afinal a arte não muda o mundo, mas altera o pensamento do homem permitindo a transformação da realidade. Segue a este um capítulo com um breviário político de 1914 a 1930, analisando os derradeiros governos da Primeira República ou República Velha.

Não se poderia estudar a História do Brasil sem inseri-la no contexto mundial. Nossa realidade política e social é construída internamente, entretanto as políticas econômicas adotadas e o desenvolvimento do país seguem uma lógica que quase sempre ou, em verdade, na maioria das vezes, está intrinsecamente interligada ao capitalismo internacional. Um país agrário, dependente financeiramente dos grandes bancos estrangeiros, governado por elites políticas subservientes e que adoravam passear pela Europa, a ponto de alguns presidentes da República Velha sequer terem votados em si mesmo, pois faziam o famoso tour dos eleitos pelo Velho Continente, viagem que duravam vez ou outra, meses. Desconsiderar esse aspecto e considerar que nossa economia caminhava pela sua dinâmica interna apenas é temerário. Escolheu-se 4 
temas que de alguma forma influenciaram o caminho de Percival Farquhar por terras brasileiras: o Imperialismo, pois o americano foi acusado de ser um polvo imperialista; a Grande Guerra, que com sua escassez de capitais foi um dos fatores da destituição do empresário quacre do Brasil; a Crise de 1929, um dos principais fatores da queda da República Velha e do praticamente cancelamento da Itabira Iron em 1931 com a ascensão de Getúlio Vargas; e a Revolução Russa introduzindo os novos atores sociais com seu discurso nacionalista e anti-imperialista, fechando o sexto capítulo.

O mais longo dos capítulos é o sétimo. Uma interpretação possível da economia brasileira no período da República Velha. Inicia com uma descrição dos ciclos econômicos, permitindo uma análise do mito de Sísifo, nosso eterno karma econômico. As alterações provocadas pelo café e a disputa entre Metalistas e Papelistas ( que num certo sentido, eram as disputas entre agraristas e industrialistas). Há também uma análise da moeda no capitalismo, bem como uma breve história da moeda no Brasil. As sucessivas crises de endividamento e as principais doutrinas que influenciaram os economistas do Brasil também é tema deste capítulo, que prepara para a interpretação das fontes primárias utilizadas nesta tese.

O derradeiro capítulo é uma interpretação dos discursos proferidos pelos ministros da Fazenda entre 1898 e 1915. São relatórios completos redigidos em respeito ao artigo $5^{\circ}$ da Constituição de 1891 e apresentados ao presidente da República em exercício. São 16 relatórios distintos produzidos por 6 ministros da Fazenda, a maioria deles Metalista, com breves intervalos Papelistas. Analisou-se mais profundamente o discurso de Joaquim Murtinho, o grande norteador das políticas Metalistas dali para a frente. Os textos de época nos permitem sentar à mesa como queria Walter Benjamin, e entender melhor o período estudado.

Um período de permanências em meio a turbulentas transformações sócias. Era de uma classe dominante dotada de muita saúde, de muita violência no exercício do poder, de muito capital. Classe esta nacionalista por conveniência e xenófoba ao capital estrangeiro quando lhe trazia poucos lucros ou concorrência direta. Dona de grandes latifúndios e aos poucos concentrando grandes conglomerados empresariais. Tudo isso em meio a uma convulsão social com a urbanização, industrialização, luta pelos direitos sociais e migração em massa de mão de obra. Enfim, para esta Tese:

A história é um velho museu abandonado, todavia vivo e pulsante. As janelas estão quebradas e há frestas por todos os cantos, vítimas da passagem inexorável dos dias e estações. Então, vez ou outra, o vento — gélido ou cálido —, as chuvas — 
torrenciais ou intermitentes - , penetram nos aposentos e nos confundem a mente com as notícias do presente. Adentramos a este museu e passaremos acelerados por seus corredores. Estes nos levam a imensos salões de bailes em que apenas poderemos observar as danças de época e não entender corretamente os pretéritos jogos de cena, as disputas de honrarias. Subiremos as escadas e entraremos nos quartos proibidos, nas alcovas de outrora, perdendo detalhes e sussurros pela imensidão de imagens e a confusão produzida pelos ausentes. Entretanto, encontraremos nessa estrutura carcomida, nas descascadas pinturas de paredes, a vida que existiu um dia, as necessidades pertences daqueles atores. Nunca exatamente como a encenaram, mas por dentro de suas personas, como nem eles mesmos a viam ou aceitavam. 


\section{CAPÍTULO 1 - PERCIVAL FARQUHAR}

O Bruxo do Cosme Velho exala toda sua ironia e o tom provocativo, além de um abuso deliberado no início de Memórias Póstumas de Brás Cubas (1881). Reinventa o romance ao criar o narrador-personagem que é um defunto-autor. A onisciência e onipotência de Brás Cubas é completa, afinal ele já conhece a história do princípio ao fim. Contrariamente ao tradicional, a narrativa desse mestre na periferia do capitalismo ${ }^{4}$ descreve a vida sob o ponto de vista de um morto. Walter Benjamin, como visto, queria banquetear com os mortos para entender a História. Machado de Assis faz com que os vivos sejam convidados a cear com um morto para nos contar sua estória. Nas palavras de Brás Cubas descritas assim:

Algum tempo hesitei se devia abrir estas memórias pelo princípio ou pelo fim, isto é, se poria em primeiro lugar o meu nascimento ou a minha morte. Suposto o uso vulgar seja começar pelo nascimento, duas considerações me levaram a adotar diferente método: a primeira é que eu não sou propriamente um autor defunto, mas um defunto autor, para quem a campa foi outro berço; a segunda é que o escrito ficaria assim mais galante e mais novo. Moisés, que também contou a sua morte, não a pôs no intróito, mas no cabo: diferença radical entre este livro e o Pentateuco. ${ }^{5}$

Esta tese fará uma inversão da ordem cronológica. A exemplo de Brás Cubas e seu defunto-autor colocará seu personagem principal - Percival Farquhar —, não ao cabo, mas no introito. É a memória histórica de um indivíduo único e perfeitamente inserido no contexto histórico. Um homem de ação e de expansão imperialista. Um colonizador num país de industrialização tardia.

Num de seus contos, denominado "O espelho”, Machado relata a estória de um pobretão que se torna alferes do Império. O alferes vai residir em casa de uma tia viúva e grande proprietária. Esta tem uma adoração pelo sobrinho e ele passa a viver em função da titia. Numa das viagens o alferes conta aos amigos sua crença de vida: o homem possui duas almas, uma interior e a outra exterior. Ser alferes era sua imagem interior, o homem a exterior. O espelho em questão fora presente de sua tia. Aos poucos

\footnotetext{
${ }^{4}$ SCHWARZ, Robert. Um mestre na periferia do capitalismo. 1990

${ }^{5}$ ASSIS, Machado. Memórias póstumas de Brás Cubas. 1996. Pág. 13
} 
o narrador se apercebe que refletida ao espelho sua imagem estava desaparecendo. Em virtude disso, ele tem a ideia de vestir-se de alferes e olhar-se no espelho. Lentamente, sua imagem externa adquire a forma da interna, um alferes.

Essa temática retorna no próprio "Memórias Póstumas" que abriu este capítulo. Brás Cubas filosofa sobre a importância das vestimentas para a definição social ${ }^{6}$. A inspiração de nosso maior escritor é certamente a obra de Carlyle "Sartor Resartus" (talvez o " alfaiate recosturado"). Nesse misto de romance com fatos históricos filosóficos, um editor recebe uma estranha filosofia para ser traduzida e publicada em inglês. Nela Diógenes Teufelsdröckh ( literalmente 'o filho de Deus' e 'o estrume do diabo'), defendia que as convenções sociais são determinadas pelas roupas.

O historiador escocês Thomas Carlyle ( falecido em 1881, coincidentemente o ano de publicação de Memórias Póstumas), defendia que a História Universal é a somatória de milhares de individualidades. Certos personagens históricos, na visão historicista do autor de "A Revolução Francesa" e "Passado e Presente", alguns personagens históricos, por sua riqueza, ou sua representatividade, ou ainda pela capacidade de interferir nos acontecimentos históricos tornam-se herois atemporais e capazes de trazer dentro deles uma espécie de luz e resumo sobre uma determinada época. Questiona-se sobre a existência de um inexorável destino ou da possibilidade de interferência de homens "especiais":

Quais podem ser os objetivos e significados da espetacular transformação na vida humana que investiga e relata? Quando o curso dos destinos dos homens na Terra foi originado, e para onde ele tende? Será que realmente eles têm qualquer curso ou tendência, são eles [os destinos] realmente conduzidos por uma sabedoria invisível e misteriosa, ou será que simplesmente giram cegamente em um labirinto, sem nenhuma liderança reconhecível ${ }^{7}$

Algumas vidas heroicas, segundo Carlyle, nos permitem recapitular o passado: A vida social é a agregação da vida de todos os indivíduos que constituem a sociedade: a história é a essência de inumeráveis biografias. Mas se uma biografia que não nossa própria, estuda e

\footnotetext{
${ }^{6}$ ASSIS, Machado. Memórias póstumas de Brás Cubas. 1996. Capítulo XCVIII, ironicamente descrito como “ Suprimido". Pág. 135

${ }^{7}$ CARLYLE, Thomas. “On History” In: Thomas Carlyle: selected writings. Harmondsworth: Penguin Books, 1986. Pág. 56. Citado por ANDRADE, Débora El-Jaick. In: Escrita da história e política no século XIX: Thomas Carlyle e o culto aos heróis. História e Perspectivas, Uberlândia (35): 211-246, Jul.Dez.2006
} 
recapitula os fatos da melhor maneira possível, permanece em muitos aspectos ininteligível para nós [...]. ${ }^{8}$

O historiador ( epíteto que vai contra a vontade de muitos acadêmicos) Carlyle possuía um entendimento próprio do que seria a História. Visão equivocada e repleta de vícios, mas como toda interpretação histórica o é. Ou como diria Claude Levi-Strauss "a escolha relativa do historiador é sempre entre uma história que informa mais e explica menos e uma história que explica mais e informa menos". Entende Carlyle que a:

História Universal, a história de tudo que o homem realizou neste mundo, no fundo é a história dos grandes homens que aqui trabalharam. Eles eram os líderes dos homens, estes grandes indivíduos, eram os modelos, os exemplos e em amplo sentido, os criadores do que quer que a grande massa dos homens planejam fazer ou atingir. Todas as coisas que vemos já realizadas no mundo são propriamente o resultado material exterior, a percepção prática e corporificada de pensamentos que habitavam as mentes dos grandes homens enviados ao mundo: a alma da história inteira do homem, pode ser acertadamente considerada, a sua história. ${ }^{9}$

Percival Farquhar é o heroi meio macunaímico desta tese. Gauld o via repleto de caráter. Guinle, Calógeras, Alberto Faria, Artur Bernardes enxergavam-no enviesados como um polvo e seus tentáculos imperialistas. Nascido em York (Pensilvânia) em 1864, Farquhar desceu no Rio de Janeiro ( a capital sem porto nem docas, obras estas que seriam realizadas pelo industrial americano) em início de 1905. Num turbilhão de ideias e investimentos abriu 38 empresas, uma gigantesca holding cujo eixo central era a Brazil Raylway Company. Ergueu ferrovias, portos, docas, abatedouros e frigorífico. Comprou fazendas e engordava gado, adquiriu barcos de transporte, montou serrarias. Explorou erva mate. Ganhou a concessão dos bondes no Rio e em São Paulo. O fornecimento de gás, de eletricidade e a produção de energia da capital federal foram ramos do seu império. Toda a telefonia do Rio e da região norte do país foram concedidas às suas empresas. Tudo isso entre 1905 e fins de 1914. Investiu US\$ 180

\footnotetext{
${ }^{8}$ CARLYLE, Thomas. “On History” In: Thomas Carlyle: selected writings. Harmondsworth: Penguin Books, 1986. Pág. 56. Citado por ANDRADE, Débora El-Jaick. In: Escrita da história e política no século XIX: Thomas Carlyle e o culto aos heróis. História e Perspectivas, Uberlândia (35): 211-246, Jul.Dez.2006

${ }^{9}$ Idem. Ibidem
} 
milhões no Brasil nesses 10 anos. Em valores atualizados ${ }^{10}$ teríamos absurdos US\$ 4,4 bilhões. Em 1914, ano da Grande Guerra, o Produto Interno Bruto brasileiro atingiu US\$ 7,3 bilhões ( dados do IBGE), ou seja, Farquhar investiu o equivalente a 2,5\% da soma das riquezas do país.

Decretada a recuperação judicial de suas empresas ( em 1914), Farquhar tenta manter sua permanência nas empresas por mais três anos. Definitivamente escorraçado dos negócios ( entre 1917 e 1919) desfaz-se o império da Brazil Raylway. Derrotado, ele não desiste de investir no Brasil e em 1921 retorna ao país com um novo projeto: a Itabira Iron Company, um imenso complexo siderúrgico, um "Rhur brasileiro" como o empresário americano gostava de denominar. Idas e vindas políticas, resistências xenófobas e anti-industrialistas de um lado, nacionalismo estatista de outro, Farquhar observou seu projeto ficar engavetado por 21 anos, até ser finalmente expropriado por Getúlio Vargas. Negociador hábil, Farquhar não demonstrava rancor nem ódios, afinal precisava dos políticos para novos projetos. No país de Capitu é essencial dissimular os sentimentos. Aos 80 anos, ainda sobre governo Getúlio Vargas, Farquhar anuncia seu último projeto no Brasil: uma siderúrgica e uma cidade operária próxima a Itabira (MG), o projeto da Aços Especiais Itabira ( Acesita). Curiosamente dessa vez não sofreu resistência. Talvez porque passasse na cabeça de nossos políticos e empresários que "esse morre logo". Farquhar finalmente pode exercer seu empreendedorismo com sossego por 7 anos. A partir de 1951, bastante doente, ele vai se afastando dos negócios e dois anos depois falece nos Estados Unidos.

Pelo volume de recursos, a quantidade de projetos, o tempo dos negócios ( entre alguns hiatos no tempo foram 48 anos de atividades no Brasil), a dimensão estratégica das empresas, a permanência das ideias ( muitos dos tentáculos de Farquhar são atualmente empresas lucrativas), ou pelo modelo de exploração econômica adotado ( as concessões públicas para empresas privadas), o estudo de Percival Farquhar é essencial para o entendimento do desenvolvimento econômico brasileiro. Dos erros e tragédias, dos interesses e favores, dos percursos equivocados e vitoriosos de nossa história e , principalmente das permanências.

\footnotetext{
${ }^{10}$ Estatísticas baseadas no Consumer Price Index. Realizadas pela MeasuringWorth. Num ano qualquer levanta-se o custo um pacote de bens, de compras e de serviços realizados por um típico consumidor urbano, comparando-se depois com um pacote de bens, de compras e serviços num período solicitado. Trata-se de uma medida correta da inflação, porque limita a bens e serviços de consumo. A série utilizado na Measuring Worth é a mesma dos United States Bureau of Labor Statistics. Acessado em 05 de novembro de 2016. https://www.measuringworth.com/aboutus.php
} 


\subsection{O Modelo de Negócios de Percival Farquhar}

Na metade do século XVII — em meio às revoluções inglesas —, George Cox, filho de um abastado sacristão puritano, instituiu uma nova fé denominada de "Sociedade dos Amigos" ou simplesmente "Quaker". Acreditavam na predestinação, na perseverança, no igualitarismo das origens cristãs e, revolucionariamente, que a luz divina está em cada um de nós, sem a necessidade de intermediários ( padres, pastores, clérigos, etc.), nem de igrejas ou templos. Desafiaram o poder de privilégios da monarquia britânica e as relações meio espúrias do anglicanismo nascente. Defendiam ainda que a vida em retidão era um desígnio de Deus. Cresceram na Revolução Gloriosa, mas depois foram perseguidos com a Restauração. Cox expande sua fé pela América do Norte. O método litúrgico era simplificado: os fiéis se reuniam um frente ao outro até que um deles ( ungido pelo espírito santo, na crença Quaker) começava a falar e pregar. A técnica do silêncio, da conversa firme "olhos nos olhos" e a convicção da "revelação" dos quakers, foram utilizadas em larga escala pelo empresário Farquhar.

Filho de milionários Quakers, Percival Farquhar formou-se em engenharia em Yale e depois iniciou o curso de direito ( o qual, apesar de exercer a profissão no escritório novaiorquino de John dos Passos, homônimo e parente do escritor e pintor de "Manhatan Transfer", não tornou-se sua principal atividade). Nos anos 1890 Farquhar muda-se para Nova York iniciando sua relação com ferrovias ao tornar-se executivo da Staten Island Eletric Railway Company. Entre 1893 e 1895 foi deputado distrital em Nova York. Sua rápida ascensão no mundo dos negócios nesse primeiro momento foi ligado a dois fatores: a abastada família e os contatos com dezenas de quakers ricos nos meios empresariais norte-americanos.

Percival Farquhar queria mais. Enxergou nos países latino-americanos possibilidades infinitas de negócios. Sua primeira investida ocorreu em Cuba, país em que construiria uma rede de serviços públicos e posteriormente uma ferrovia. Depois de uma breve passagem pela Guatemala, ele aporta no Brasil. Aqui centralizou seus investimentos. Daqui ele expandiu negócios para a Bolívia, Chile e Paraguai e iniciou negociações com a Argentina. O modelo de investimentos de Farquhar foi sempre o mesmo:

I) Buscava um país de economia primária, carente de serviços públicos diversos, sem uma logística de transportes ou com um sistema de escoamento de mercadorias deficiente;

II) Contratava técnicos renomados e visitava a região pessoalmente; 
III) Contatava as lideranças políticas, ministros, presidentes, ditadores, generais no comando ( como a Cuba controlada pela USMG).

Charles Gauld ${ }^{11}$ revela a presença corrupção como forma de expansão dos negócios de Farquhar em vários momentos da biografia, mas sempre a origem da mesma estaria nos costumes pérfidos latino-americanos e nunca foi paga diretamente por Farquhar, afinal este era um sério Quaker. Curioso que o os dois (biógrafo e biografado) criticavam ferozmente Getúlio Vargas, pois este, na visão deles, era pessoalmente honesto, entretanto permitia uma corrupção sem tamanho no governo.

IV) Aliava-se a poderosos empresários e montava uma sociedade;

V) Farquhar criava e registrava suas empresas no Maine (Portland) ou em Nova Jérsei, pois lá havia os menores tributos americanos ou simplesmente leis favoráveis;

VI) Com a empresa registrada ele recebia as concessões públicas de serviços, estradas e portos dos governos, utilizando-se das boas relações com o poder e de polpudas propinas;

VII) Farquhar buscava então investidores para seus projetos. Na maioria das vezes, o capital investidor provinha da Inglaterra, França, Alemanha e Bélgica. Seu país natal pouco investiu, inclusive colaborou para a sua exclusão da Itabira Iron. Este fator por si só é um contraponto ao nacionalismo xenófobo e ao medo de uma invasão americana no Brasil;

VIII) Com a emissão das ações e o dinheiro em mãos Farquhar iniciava e concluía as obras;

IX) A renda e os lucros dos investimentos empresariais seriam conquistados pelas tarifas da exploração dos serviços ou por meio do pagamento de juros pelos "empréstimos" obtidos. No Brasil, o governo costumava pagar 6\% de juros anuais. Ou seja, o capital seria amortizado em 17 anos.

\subsection{Percival Farquhar além do Brasil}

\subsubsection{Cuba}

Cuba acabara com a dominação espanhola em 1898. O primeiro governo "livre' do país foi exercido por uma junta militar norte-americana, a United States Military Governement (USMG). Dois generais administraram a ilha entre 1898 e 1903, John

\footnotetext{
${ }^{11}$ Devida a profusão de fontes, a biografia de Charles A. Gauld será a base deste capítulo. Os dados são: GAULD, Charles A. Farquhar, o último titã. Editora da Cultura. São Paulo. 2005.
} 
Brooke e Leonard Wood. Tal fato facilitou a entrada de Farquhar no país. Cuba era um país paupérrimo com atividades comerciais tradicionais do rum e tabaco.

De Havana, na costa oeste até Santa Helena ( na outra extremidade), são pouco mais de $1200 \mathrm{~km}$. Não havia nem 200km de ferrovias construídas. Nas cidades maiores os serviços públicos eram praticamente inexistentes. Havana, por exemplo, possuía uma precária estação telefônica com 1500 assinantes. A Emenda Platt ( introduzida por Elihu Root, secretário da Guerra americano em 1903) previa o fornecimento de uma série de serviços públicos para a capital cubana, bem como a construção de uma base militar em Guantánamo ( próxima a Santa Helena). Era a estratégia geopolítica norteamericana. Depois da "América para os americanos", logo seria a vez da Política do Big Stick. O imperialismo expandiu seu território colonial e Farquhar era um emissário dos novos tempos.

Farquhar procura William Van Horne, magnata da Canadian Trailway e Minor Keith, proprietário da United Fruit Company para vender suas ideias de investimentos em Cuba. Uma delas seria a construção de uma série de serviços públicos em Havana, a capital. O empresário inicia seu império particular encampando o serviço de gás e eletricidade da cidade de Havana. Logo depois passa a explorar o transporte de bondes na capital de José Martí. Após longas negociações, em 1912 organiza-se uma corporação que centraliza todas essas atividades, a Havana Electric Railway, Light \& Power Company, a primeira de Percival Farquhar.

Entre 1900 e 1903 Farquhar constrói sua primeira grande ferrovia. Sua fixação com os trens talvez seja um dos motivos de sua queda financeira em 1914. Construída com técnicas avançadas ( Farquhar, apesar das dezenas de críticas sobre os métodos de obtenção da concessões públicas, bem como às formas de exploração da mão-de-obra nos seus projetos, sempre conseguiu concluí-los e com construções de boa qualidade). A Cuba Railroad atravessou o país caribenho de Havana a Santa Clara em 573 quilômetros de trilhos de bitola padrão num custo estimado de US\$ 10 milhões ( valores de 1903). Farquhar aproxima-se do primeiro presidente cubano, Tomás Estrada Palma e ganha as concessões para explorar a ferrovia e uma área adjacente de 300m de cada trilho, na qual desenvolveu canaviais e serrarias. Em 1947 os negócios de Farquhar constituíam-se das empresas Cuba Railroad e Cuba Company que controlavam 1280 quilômetros de ferrovias em Cuba, possuíam 40 mil hectares de terras e plantações, além de duas usinas açucareiras. Valiam US\$ 80 milhões naquele ano. 


\subsubsection{Guatemala}

De Cuba, Farquhar parte para a América Central Ístmica. Seus tentáculos de polvo estenderam-se até a Guatemala. ${ }^{12} \mathrm{Na}$ terra dos antigos maias ele ergueu a Guatemala Railway entre 1903 e 1908 ( período em que já possuía concessões no Brasil). O trajeto cruzava o país de sul a norte entre a Cidade da Guatemala e Puerto Barrios. Farquhar edificou 217 quilômetros de trilhos, além de refazer totalmente os terríveis 96 quilômetros de ferrovias já existentes. Mais uma vez sua boa relação com o poder político representado pelo ditador Manuel José Estrada Cabrera ( governou entre 1898 e 1920) facilitaram as coisas. Farquhar ganhou uma concessão válida até 1950, bem como áreas adjacentes a ferrovia construída. Recebeu também terras de bananais e café ( principais produtos econômicos dos guatemaltecos no período). Sun Bugget, vice presidente da United Fruit, assim descreveu os negócios guatemaltecos:

Percival Farquhar desempenhou papel proeminente na aquisição da principal concessão de ferrovia e Keith e Van Horne não perderam tempo em ratificá-la...ele era vice presidente da Guatemala Railway em 1905...A ferrovia e os 20mil hectares de bananais de Puerto Barrios foram fatores importantes no desenvolvimento inicial da bananicultura na costa norte da Guatemala. Reciprocamente, o fato da United Fruit ter iniciado sua produção no local ajudou no progresso da ferrovia...O contrato era, na verdade, um acordo de comércio de longo prazo, que trazia benefício para as duas partes. ${ }^{13}$

\subsubsection{União Soviética}

Como as negociações pela Itabira Iron emperraram, Farquhar buscou expandir seus negócios para o espectro europeu. Buscou o terceiro cavaleiro do apocalipse, a União Soviética. Lênin acabara de instituir a Nova Política Econômica (NEP) e aceitou negociar com o empresário ianque. O projeto de Farquhar era semelhante ao da Itabira Iron. Iria dotar o país socialista de um complexo industrial mineral-metalúrgico e siderúrgico na bacia do Rio Donets ( atual Ucrânia). O projeto constava de uma siderúrgica construída nos mesmos moldes dos negócios brasileiros, seria a Makeeva Steel Works. O minério de ferro teria sua exploração realizada na região de Krivoy Rog ( área que produzia cerca de 6,5 milhões de toneladas de minérios anuais em 2010) e,

\footnotetext{
${ }^{12}$ Curioso notar que o líder revolucionário argentino Che Guevara fez o caminho inverso de Percival Farquhar: foi da Guatemala a Cuba e lutou pelo fim da exploração capitalista na América Latina

${ }^{13}$ GAULD, Charles. Farquhar, o último titã. Pág. 103
} 
por último, a construção das ferrovias Ekaterina Raylway e Donets Raylway. As negociações são suspensas em 1924 com a morte de Lênin. Em 1927 Stálin as reinicia e cancela o projeto no ano seguinte. Farquhar buscou comitês de arbitragem internacionais, pois havia uma cláusula de multa de US\$ 600 mil em caso de desistência de algumas das partes. A União Soviética foi condenada e Stálin pagou a indenização. No final dos anos 30 Stálin procurou o empresário novamente e este não aceitou negociar. Dizia que os comunistas não mantinham a palavra. Bom eram os capitalistas brasileiros: Getúlio após negociar e protelar o projeto da Itabira Iron por 12 anos, a encampa e estatiza em 1942. Claro, sem nunca pagar o devido a Farquhar, conforme acordado.

Para um estudo mais aprofundado do tema Farquhar-União Soviética, toda a correspondência, os memorandos e os relatórios referentes às negociações entre o empresário quacre e o governo soviético encontram-se arquivados no Instituto Hoover da Universidade de Stanford e estão inacessíveis online, infelizmente.

\subsubsection{América do Sul}

Estabelecido no Brasil e no ápice dos negócios, em 1912 Farquhar cria a Uruguay Central Railway e a Argentine Railway Company. Era necessário estabelecer uma imensa rede ferroviária transcontinental em todo o Cone Sul. Compra no mesmo ano a maioria das ações da Bolivia Railway Company. Esta teria ramais em La Paz e Antofogasta no Chile. A Bolívia teria sua saída para o mar e os Andes seriam salpicados pelos trilhos de Farquhar. No ano seguinte ele adquire o controle da Assunción Tramway, Light \& Power Company e da Paraguay Central. Neste último país Farquhar importa gado e criadores do Texas, começando suas atividades no setor pecuário (costumava se gabar dizendo possuir mais de 700mil cabeças). No ano da Revolução Russa ele institui a International Products Company, a mais rentável e, em verdade, a única a sair do papel dos projetos sul-americanos. Farquhar teve vultosos lucros com a exploração da carne nas terras paraguaias da International, direcionadas para o frigorífico criado por ele em Osasco. Além disso, a empresa controlava o importante mercado de exportação do tanino ( extraído do quebracho), o qual atravessava ferrovias brasileiras de Farquhar até o Porto de Santos. O empresário Quaker era um estrategista. 


\subsection{A Primeira Fase Brasileira}

\subsubsection{Rio de Janeiro}

Em 1904 Percival Farquhar recebe de seu pai um volumoso relatório sigiloso sobre projetos de fornecimento de serviços públicos na capital do Brasil. As informações privilegiadas e certamente surrupiadas de outros empresários fez o empresário norte-americano visualizar seu Congo, o império privado do Rei Leopoldo II da Bélgica. Sua terra das possibilidades infinitas. Em Maio daquele ano ele registra em Nova Jérsei sua primeira empresa para explorar as concessões públicas brasileiras; a Rio de Janeiro Light \& Power Company. Procura Frederick Pearson e Alexander Mackenzie, donos do grupo Light \& Power, que controlavam os serviços públicos de São Paulo ( São Paulo Tramway, Light and Power Company) para apresentar sua estratégia empresarial. Negocia com os financiadores europeus, lança os papéis e aporta no Rio de Janeiro em começo de 1905.

Farquhar contava com vários trunfos: primeiro, a estabilidade monetária conquistada após a política recessiva de Joaquim Murtinho, deixando os investidores mais confiantes num retorno rápido dos capitais; segundo, a transformação quase completa do velho centro e de parte da orla carioca com o bota-abaixo de Rodrigues Alves, Pereira Passos e Oswaldo Cruz; e terceiro, a urbanização e industrialização crescentes da capital brasileira.

A péssima qualidade dos serviços públicos de um lado, a sua carência do outro (não havia iluminação artificial nas ruas da capital, ao contrário do que ocorria em São Paulo), ou ainda a ineficiência das empresas concessionárias fizeram com que, em pouquíssimo tempo, Farquhar monopolizasse os serviços. Faziam parte desse monopólio que foi transferido a Farquhar: a iluminação a gás das ruas pertencentes a Societé Anonyme du Gaz de Rio de Janeiro, empresa belga, os 322 quilômetros de bondes pertencentes ao Deutsche Bank e a telefonia pertencente a Brasilianische Elektricitäts Gessellschaft ${ }^{14}$ com seus 220 assinantes ( Havana possuía 7 vezes mais como vimos). Além disso, Farquhar recebe a concessão do fornecimento de luz e da produção de eletricidade.

Percebe-se que duas das críticas a Farquhar são datadas. A primeira é de que era necessário proteger a indústria nacional. Todas as concessões do Rio e São Paulo —

\footnotetext{
${ }^{14}$ Assim dizia o Decreto 3250/ 1899: Artigo unico. E' concedida autorização á «Brasilianische Elektricitäts Gesellschaft» para funccionar na Republica, mediante as clausulas que com este baixam, assignadas pelo Ministro da Industria, Viação e Obras Publicas e ficando a mesma sociedade obrigada ao cumprimento das formalidades exigidas pela legislação em vigor. Capital Federal, 7 de abril de 1899, $11^{\circ}$ da Republica. M. Ferraz de Campos Salles.
} 
antes dele chegar ao Brasil —, pertenciam a grupos estrangeiros: alemães, ingleses, belgas, americanos e franceses controlavam os serviços públicos de São Paulo e Rio de Janeiro. Pensando no capital financeiro ( lembramos do capítulo 4), a República Velha foi uma sucessão de empréstimos bancários conseguidos em instituições internacionais, fatores que elevavam a dívida externa e a dependência econômica, tudo em nome do capital nacional, ou seja, do interesse dos cafeicultores. A outra seria a de que Farquhar foi um empresário sem escrúpulos que colocou o Brasil em seus tentáculos de polvo imperialista ( como os Guinle costumavam falar). As concessões, como o nome já diz, partiam dos interesses dos governos republicanos e não das exigências de Farquhar. Quem quis lotear o país e entregá-lo ao investimento externo foram nossos governantes, Farquhar como todo bom empresário era um estrategista e abocanhou as benesses do estado.

Farquhar constrói a Usina Hidroelétrica de Lajes $(\mathrm{RJ})^{15}$, a primeira da capital. Moderniza o sistema de bondes e amplia as linhas e as áreas atendidas ( cobra passagens caras, um de seus erros), instala os primeiros postes de iluminação artificial da capital, importa fogões caseiros e os vende para os moradores do Rio para suprir a queda no consumo de gás, afinal a iluminação das ruas era realizada por lampiões a querosene e a gás e com a eletricidade o consumo das duas fontes de energia cai bastante. Na telefonia ele expande o sistema e abre espaço para a futura Companhia Brasileira de Telefonia (CTB). Farquhar tinha seus preconceitos contra os latinos e desprezava boa parte da classe política da região, mas uma coisa é certa: ele prestava atenção em nossos costumes. Ao perceber que as linhas de telefone não vendiam, descobriu que um dos fatores era porque a lista telefônica trazia o costume europeu e americano, procurava-se um assinante pelo sobrenome e depois o nome. Farquhar mandou inverter. Por aqui se conhece as pessoas pelo prenome e pelos diminutivos sentimentais.

A expansão dos negócios de Farquhar provoca a ira dos industriais que controlavam a Docas de Santos ( única do país, afinal a capital federal não possuía sua Doca, obra que será realizada posteriormente pelo empresário americano), os empresários Cândido Gaffrée e Eduardo Palassin Guinle. Gaffrée e o filho de Eduardo Guinle, Guilherme, foram os mais aguerridos inimigos de Farquhar, compravam jornais e políticos para desfazer a imagem do empresário Quaker no Brasil. A lenda diz que

\footnotetext{
15 A Represa de Lages tinha uma barragem de $35 \mathrm{~m}$ de altura e um lago de 220 metros de largura, com uma capacidade de 210 milhões de metros cúbicos de água. Guilherme Guinle solta venalmente na imprensa que a epidemia de dengue que assolava o Rio era culpa da construção. Farquhar contrata Oswaldo Cruz e este após vários testes nega a informação.
} 
Guilherme, em verdade, era filho de Cândido, afinal os dois milionários dividiam não só os negócios, mas a esposa de Guinle, a excêntrica Guilhermina. Um dos sobrinhos e herdeiros do Império dos Guinle, o playboy Jorginho Guinle, costumava denominar o tio de Gaylherme. Talvez a família tenha inspirado o segundo ato do Rei da Vela de Oswald.

Farquhar e seus sócios Mackenzie e Pearson conseguem depois de longa batalha manter a concessão comprada de William Reid ( a concessão Reid de 1900) e evitar o Decreto 1001 ( de 1905) que permitia a concorrência no setor elétrico e o fim dos monopólios, ou seja, a lei garantia a luta de Farquhar contra Goffrée e Guinle, batalha que perdurará até 1915, com a derrocada empresário norte-americano.

No auge da riqueza em 1912 Farquhar recebe a concessão para construir um complexo hoteleiro e cinematográfico na região do Convento da Ajuda, uma espécie de Hollywood tupiniquim. O projeto acabou nunca saindo do papel, mas nos anos 20 a região passou a ser denominada de Cinelândia, tornando-se um dos maiores centros culturais da capital federal. Nesse mesmo ano, Alberto de Faria, jornalista e escritor carioca, foi um dos mais virulentos a discursar contra Farquhar. Num dos artigos publicados no Jornal do Commercio em 19 de outubro de 1912 denominado "O trust é o inimigo ou Tenho medo, sim!", ele escreveu:

Aqui, um syndicato, ou antes, um homem detêm em suas mãos todos os meios de transporte de mais da metade da população brasileira, atravessa-se na entrada dos nossos melhores portos, monopoliza os tramways, a luz, a força na Capital e em varias cidades, obtem de uma assentada e grátis 60.000 kilometros quadrados no Pará, na fronteira; enfim ( para antecipar o futuro de tres a cinco annos apenas) fica dono, senhor, possuidor ou usofructuario de todo o Brasil! E todos se calam!

Não cansados de dar do mundo os mais tristes espetáculos, vamos offerecer este, com seus perigos e humilhações - uma nação de 25 milhões de homens enfeudados ao senhor Farquhar. ${ }^{16}$

Bom era ser governado pelos senhores Guinle \& Goffrée e seu império “nacional” bilionário construído à custa de corrupção política, monopólios de mercado e exploração da classe trabalhadora e que foi capaz de erguer dezenas de palácios e

\footnotetext{
${ }^{16}$ Citado por LOBO, Helio. Docas de Santos: Suas Origens, Lutas e Realizações. Typ. do Jornal do Commercio Rodrigues. Pág. 388. Rio de Janeiro. 1936. Pág. 388
} 
palacetes suntuosos espalhados pelo Rio, com as tubulações levando água do mar para as piscinas da mansão de Guilhermina Guinle, enquanto os estivadores e os trabalhadores urbanos viviam na miséria. Bajulando os poderosos de então, Faria tornou-se imortal, sem ser escritor foi parar na Academia Brasileira de Letras de Machado de Assis, quase um século depois a farsa se repete com o jornalista de vernáculo lastimável Merval Pereira.

\subsubsection{Salvador}

Farquhar parte para a antiga capital brasileira. Em 1905 cria a Bahia Tramway, Light \& Power Company e começa a repetir o modelo carioca: alia-se a Mackenzie e Pearson e consegue a concessão de transporte de bondes em Salvador. Compra a Bahia Gaz Company e a Compagnie d'Eclairage de Bahia. Ou seja, concentrara a produção de luz, gás, transportes públicos e ainda recebera o direito de construção de uma hidroelétrica na Bahia. O combate entre os dois impérios industriais Gaffrée \& Guinle versus Farquhar é transferido para a terra de Jorge Amado. Em 1909 um acidente inicia o declínio do americano em Salvador. Um dos bondes da Tramway atropela e mata um soteropolitano cego. A revolta popular é grande. Os jornais baianos devidamente pagos por Gaffrée \& Guinle estimulam a rebelião. Farquhar buscou tratar a questão social como um caso de polícia, o que sempre funcionava no Brasil. Esqueceu-se do discurso nacionalista ${ }^{17}$. Dezenas de trens foram destruídos ou incendiados. A reação emocional dos brasileiros o incomodava. Deixou os negócios baianos pra trás em 1913 dizendo que os habitantes da antiga capital eram “ corruptos, desleais, instáveis e de baixo nível moral". 18

\subsubsection{Belém}

Farquhar sabia que seus inimigos tornaram-se milionários com a concessão e a construção das Docas de $\operatorname{Santos}^{19}$. Atraído pela riqueza da borracha na região norte e a total falta de estrutura da região, num 7 de setembro de 1905 ele funda a Porto of Pará. O objetivo: construir um sistema de navegação e uma estrutura portuária para

\footnotetext{
${ }^{17}$ No final dos anos 20, os Gaffrée \& Guinle vendem seus negócios para a American Foreing Power — Eletric Bond \& Share Company. Nacionalismo de araque como sempre o de nossas classes dominantes.

${ }^{18}$ GAULD, Charles. Farquhar, o último titã. Pág. 128

19 Antes da construção das Docas, o embarque de uma saca de café custava 80 réis. Terminada a obra, o preço subiu para 150 réis a saca. Além disso, os Gaffrée \& Guinle passaram a cobrar a contestada taxa de Capatazia ( o direito de circulação pela região portuária e aduaneira). Esta era de 300 réis a saca. Os guindastes que içavam os sacos aos navios passaram de 2500 réis a tonelada para 12.200 réis ( 9700 réis de capatazia). A saca aumentara 462,5\% e a içagem $388 \%$. Lucros nacionais investidos no Palácio das Laranjeiras e seus banheiros com mármore Carrara do piso ao teto. Clóvis Bulcão, o biógrafo dos Guinle calcula que nos anos do auge da exportação ( anos 20), o negócio das Docas rendia anualmente até US\$ 24 bilhões atualizados.
} 
escoamento da produção amazônica. O "polvo do imperialismo em dólar" acertara uma garantia de $6 \%$ de juros anuais sobre o capital investido, mais $2 \%$ a título de taxa de importação. Farquhar criticava abertamente a corrupção desenfreada e a degeneração moral dos nortistas, só não explicava como conseguira as concessões. Na sua idiossincrasia pessoal com seus princípios quakers e honestidade sem fim. Jung dizia que a sombra que vemos no outro é a projeção de nossa identidade.

Farquhar compra a concessão da Ferrovia Madeira-Mamoré do milionário brasileiro Joaquim Catambry. Iludido pelas teorias de Alexander Humboldt se apropria de imensas áreas de terra na Amazônia, por acreditar que os solos eram férteis e ideais para as atividades agropastoris. A concessão para a construção do Porto de Belém lhe deu também cerca de 1000 hectares de terras na região. Farquhar trouxe gado da Ilha da Madeira e esta criação, pelas condições naturais inadequadas, fracassou. Os estrategistas militares durante a ditadura tentaram inadvertidamente criar búfalos na ilha de Marajó. Os animais chafurdaram na lama, foram abandonados e tornaram-se selvagens. Vivendo e não aprendendo.

Em 1909 ele funda a Amazon Navigation Company com o objetivo de regularizar o transporte de navegação a vapor. As difíceis obras do porto se estenderam até 1911. Nesse ano, a produção de borracha do sudeste asiático começava a suplantar a amazônica. Além disso, uma guerra de preços entre as companhias de navegação da região reduziu drasticamente o frete. Por último, a tarifa adicional de $2 \%$ cobrada por Farquhar levava os navios a preferirem o porto de Manaus. A explicação para o fracasso dos negócios é muito mais racional e lógica do que ufanismo nacionalista pretendia. $\mathrm{O}$ capital não tem bandeira. A livre concorrência, seja ela nacional ou asiática com as primeiras safras de borracha inglesa derrubou o negócio. Farquhar escreve no Jornal do Commercio em 1912 tentando defender seus projetos:

[ de que precisávamos] de esforço intellectual e moral, de educação sob todas as formas. A exploração de nossos recursos pelo estranjeiro devia-se à nossa fraqueza; e se soubéssemos ser atilados, ella só traria benefícios. A que se deve o imenso progresso da União Americana, senão do capital de fora? Na Argentina, com mais de 35.000 kilometros de vias férreas, sómente duas linhas das 26 existentes e representando apenas 3.600 kilometros não eram estrangeiras..."20

\footnotetext{
${ }^{20}$ Citado por LOBO, Helio. Docas de Santos: Suas Origens, Lutas e Realizações. Typ. do Jornal do Commercio Rodrigues. Pág. 388. Rio de Janeiro. 1936. Pág. 392
} 


\subsubsection{A Ferrovia do Diabo - Madeira Mamoré}

Com a concessão de Catambry em mãos, Farquhar cria a Brazil Raylway Company and Port of Pará ( 1906). O próximo desafio seria a construção de uma ferrovia em meio a Floresta Amazônica. Atravessaria os estados do Amazonas e Rondônia passando pela fronteira do Mato Grosso. O caminho de trem teria cerca de 350 quilômetros atravessando perigosas corredeiras e 19 cachoeiras que circundam a maior floresta tropical úmida do mundo. A construção da estrada fazia parte do acordo selado com a Bolívia em 1903. O Brasil comprara a região do Acre e se comprometera a construir a ferrovia Madeira Mamoré ( Mad Maria, como chamavam). Os percalços na construção foram muitos. Muitos diziam que Farquhar encontrara seu 'Helldorado'.

No início das obras a borracha amazônica era responsável por $90 \%$ do abastecimento mundial. A segunda revolução industrial e, especialmente, a indústria automobilística transformaram o látex numa das maiores riquezas do capitalismo. A borracha chegou a representar um quarto das exportações brasileiras. Criticar Farquhar pela escolha em construir um complexo sistema hidro-ferro-portuário na região é fácil, principalmente se analisado a distância na história. A ferrovia Madeira-Mamoré ligava o nada ao lugar nenhum, dizem os críticos. Não há nenhum texto, nenhuma análise, sequer um relatório produzido no Brasil entre 1905 e 1910 que afirme sobre o perigo da concorrência asiática na borracha. Ninguém cogitou que a participação brasileira no mercado mundial da borracha garantia apenas a $17^{\mathrm{a}}$ colocação ao país em 1916, enquanto que dez anos antes 9 de cada 10 quilos de látex no mundo vinham da Amazônia. E o que é pior: a borracha do sudeste asiático era de melhor qualidade e a extração mais simples, afinal por não ser nativa a seringueira foi plantada de forma racional.

A construção da ferrovia foi uma tragédia do início ao fim. Para os empresários da época, o custo humano era necessário em face ao progresso. Farquhar costumava edificar um canteiro de obras dotado de uma estrutura razoável. Na Madeira Mamoré foi obrigado a fazer um hospital que recebia os doentes, os acidentados e os que não resistiam ao inferno verde. Só pelo hospital passaram mais de 30 mil pacientes. Críticos diziam que a construção da ferrovia tirara uma vida a cada dormente assentado ( o que elevaria o número de mortos a casa da centena de milhar. Farquhar se vangloriava (sic) comentando que morreram no máximo 10 trabalhadores para cada quilômetro construído. Ou seja, 3500 mortos era uma cifra aceitável para os lucros do homem 
predestinado. Vidas humanas são apenas custos na mente dos empreendedores. Gauld descreve a construção dessa forma:

Pontes temporárias de madeira, galerias pluviais e cavaletes eram habitualmente levados pelas águas, e grandes trechos trilhos tinham de ser continuamente refeitos por causa das cheias. Isso era desmoralizante e tremendamente oneroso. Os empreiteiros se escoravam na experiência obtida nas terras baixas dos bananais guatemaltecos, onde 2 mil trabalhadores tinham morrido de disenteria e febres. Eles assentavam trilhos em pântanos insondáveis, colocandoos sobre um colchão feito com um trançado de galhos e uma camada de cascalho por cima. Mesmo este, às vezes, era engolido pelas águas. $^{21}$

Francisco Foot Hardman ${ }^{22}$ descreve o relatório médico de H.P. Belt em 1908. Segundo ele, o índice de operários doentes chegava a $75 \%$, atingindo quase $90 \%$ no ano seguinte, obrigando Farquhar a pedir socorro ao amigo Oswaldo Cruz ( amizade que surgiu após as análises feitas pelo sanitarista na Usina de Lajes). Belt, médico especialista em regiões tropicais, afirma que a região da Madeira Mamoré era a mais doentia do mundo. Oswaldo Cruz também produz um relatório complicado. Primeiro fala das doenças: "pneumonia, sarampo, ancilostomose, beribéri, disenteria, hemoglobinúria, febre amarela, pé-de-madeira, pinta, espundias, calazar e a mais grave, o impaludismo (malária)". Continua falando das dificuldades de recrutamento de trabalhadores, seja pela doença ou pela competição com o mercado da borracha. Referese:

(...)ao sistema de barracão ( 'adiantamento' do valor da passagem e dos gêneros fornecidos pela empresa, além da refeição diária, de baixa qualidade); menciona as quadrilhas de oito a dez homens no trabalho de linha e a forma de subcontratação, através dos 'tarefeiros'; descreve os acampamentos (...) havendo também um comedouro onde se servem as refeições, que consomem cerca de $40 \%$ do salário fictício do trabalhador... ${ }^{23}$

\footnotetext{
${ }^{21}$ GAULD, Charles. Farquhar, o último titã. Pág. 185

${ }^{22}$ HARDMAN, Francisco Foot. Trem fantasma: a modernidade na selva. $1^{\text {a }}$ reimpressão. Companhia das Letras. São Paulo. 1991. Págs. 147 e 148.

${ }^{23}$ Idem, ibidem. Págs. 149 a 152
} 
A semelhança com a história de Brian Sweeney Fitzgerald é grande. No filme "Fitzcarraldo" (1982) do diretor Werner Herzog, o personagem é um milionário excêntrico que sonha montar uma casa de ópera em meio à floresta amazônica no início do século XX. Para conseguir mais dinheiro resolve trazer um carregamento de borracha até o porto, atravessando a quase intransponível floresta, sem estabelecer limites à sua própria insanidade.

Em 1913 os negócios amazônicos de Farquhar entram na bancarrota. É obrigado a se desfazer das concessões. Os barcos encomendados a armadores holandeses tiveram de ser pagos mesmo assim. O empresário paulista Giuseppe Martinelli recompra cinco deles a um preço de US\$ 1 milhão e os traz para Santos. Farquhar perde também parte dos 5,6 milhões de hectares de terras no Mato Grosso e Pará.

\subsubsection{Sul do Brasil}

Farquhar comenta sobre o motivo do seu interesse no Brasil:

Em 1905, minha atenção foi instantaneamente atraída pelo gigantesco 'esqueleto' desconjuntado e caótico formado pelas ferrovias no Brasil. Fui informado, no Rio e em São Paulo, de que o sul do Brasil tem clima excelente. Todos me garantiram que a região era extremamente fértil, apenas à espera de ferrovias para atrair hordas de camponeses europeus famintos por terras. Em 1905, na primeira viagem do Rio para São Paulo pelo 'noturno' desembarquei na madrugada gelada de Taubaté, que era o ponto de baldeação entre a Estrada de Ferro central do Brasil, com bitola de 1,6 metro, e a linha com bitola métrica que ia para São Paulo. Durante muitos anos falou-se que os governos em nível federal, instáveis e desconfiados, temiam que os dinâmicos e ambiciosos paulistas pudessem tentar derrubar o regime no Rio. Isso quase aconteceu em 1932. O Rio aparentemente impediu a ampliação da estrada de ferro que ia de Taubaté a São Paulo até a administração competente do presidente Rodrigues Alves, que era paulista. Fui informado de que o Brasil tinha apenas 17.242 quilômetros de ferrovias de cinco diferentes bitolas - que não podiam ser conectadas, portanto. Notei a caótica variedade de locomotivas e equipamentos. Ali havia um desafio para mim como empreendedor ferroviário." 24

\footnotetext{
${ }^{24}$ GAULD, Charles. Farquhar, o último titã. Pág. 218
} 
Em 12 de Novembro de 1906, na cidade de Portland, Farquhar registra uma nova empresa para expandir seu ramal ferroviário. Sua meta agora seriam as terras do Sul do Brasil e a encampação da Estrada de Ferro Sorocabana no estado de São Paulo. A Brazil Railway Company ganhou a concessão para a construção da estrada de ferro São PauloRio Grande. O objetivo: construir uma rede ferroviária unificada, de bitolas idênticas interligando o interior de São Paulo ao do Rio Grande do Sul. A Sorocabana entrava na história, pois existe um corredor natural entre os dois planaltos que se estendem nas partes ocidental e oriental desde São Paulo até o extremo Sul do Brasil. Esse imenso corredor ( a depressão periférica encravada entre o Planalto Arenito Basáltico a oeste e os Planaltos Oriental Paulista e Primeiro Planalto do lado leste) foi fundamental para a colonização do interior do país, bem como se tornou uma das mais importantes rotas para o comércio, especialmente de muares. Criar um complexo ferroviário nessa passagem era estratégica e geograficamente essencial.

A concessão da Ferrovia São Paulo-Rio Grande trazia os usuais atrativos: juros de amortização de $6 \%$ ao ano e direito de exploração das laterais da ferrovia. Farquhar deve ter sorrido muito ao receber junto com a concessão uma área de 30 quilômetros de cada lado dos trilhos na fronteira entre Paraná e Santa Catarina. Num total de 24.000 $\mathrm{km}^{2}$ ( área quase igual ao território belga) ou 24 milhões de hectares, local em que ele teria de desenvolver atividades de colonização para estrangeiros. Somando-se esta área aos $56.000 \mathrm{~km}^{2}$ na região norte do Brasil que foram concedidos pelo governo Rodrigues Alves e Afonso Penna, Farquhar chegou a possuir quase $100.000 \mathrm{~km}^{2}$ de terras no Brasil, dimensão semelhante ao território português. A República Velha transformou o Brasil numa terra de oportunidades: dos estrangeiros.

Quatro décadas antes, dois engenheiros e empreendedores brasileiros participaram de um projeto bem semelhante ao de Farquhar. Em 1867 Antonio e André Rebouças receberam a concessão do Império para estabelecer uma estrada que ligasse a futura região portuária de Antonina até a capital do novíssimo estado do Paraná, que recém havia se tornado independente de São Paulo. Antonio queria uma estrada de rodagem, o irmão André preferia a ferrovia. O caminho de ferro sairia de Antonina, próximo ao litoral paranaense, subiria a Serra Geral até a cidade de Curitiba e de lá partiria cruzando latitudinalmente o interior até o rio Ivaí no Mato Grosso. O projeto foi alterado posteriormente e parou no trecho Paranaguá ( e não mais Antonina) a Curitiba. Antonio faleceu em 1874. André acabou perdendo a concessão em 1879 para a Cie Gênérale dês Chemies de Fer Brésiliens ( francesa) e a firma belga Societé Anonyme 
dês Travaux Dyle et Bacalan. Como sempre as permanências: o capital estrangeiro substituindo o nacional. Pouco estudada é a história dos geniais engenheiros Rebouças. Provindos da Bahia e negros numa sociedade escravista e racista.

Nessas terras sulinas Farquhar estabeleceu um imenso projeto industrial e de transportes. Pouco fez pela colonização efetiva da região. Sua preocupação central era a exploração da araucária e a exportação da erva-mate. Visava também, futuramente, construir um oleoduto da Bolívia até suas ferrovias Sorocabana e São Paulo-Rio Grande. Farquhar acreditava que o país vizinho era riquíssimo em petróleo, o que acabou se confirmando décadas depois, mas na forma de gás liquefeito. Certamente, se estivesse vivo, Farquhar apoiaria as concessões públicas para investidores privados dos anos 1990 no governo Fernando Henrique, entre elas a do gasoduto Brasil-Bolívia que em seu projeto original seguirá a mesma rota proposta por Farquhar 8 décadas antes.

Expulsando posseiros, desarticulando a economia tradicional da região, desagregando os costumes sociais e culturais dos moradores sertanejos, a Brazil Raylway, por meio de sua subsidiária, a Southern Brazil Lumber and Colonization Company estabeleceu um imenso complexo de fábricas, serrarias e produção monopolizada. Farquhar e a Southern seguiram à risca os passos da exploração imperialista descrita por Rosa de Luxemburgo: desagregar a economia tradicional, destruir suas possibilidades, criar a dependência em relação a produtos que antes nada representavam, explorar os trabalhadores sem alternativas e estabelecer um novo mercado. A Revolta do Contestado ( 1912-1916) não teve sua origem nos tentáculos do polvo, mas foi a transformação provocada pelos negócios de Farquhar o estopim da maior Guerra Civil do século XX no Brasil. Como relata Dalfré:

No caso da região onde ocorreu o Movimento do Contestado, todo esse processo foi impulsionado, entre outros fatores, pela concessão de terras à Brazil Railway Company, culminando em consideráveis alterações em relação aos interesses entre os poderes locais e estaduais, os quais, a partir de então, estabeleceram alianças objetivando maior lucro e poder. Um clima de negociatas se instaura, beneficiando chefes políticos situacionistas, membros das oligarquias e 'coronéis' influentes do interior, que se transformam em 'sócios menores', tirando proveito, ainda que marginalmente, desse surto de crescimento econômico. A emergência do trabalho assalariado nesse local 
trouxe consigo uma nova relação hierárquica, substituindo as relações de parentesco e o paternalismo característico do coronelismo brasileiro. Muitos grupos ficaram excluídos dos benefícios trazidos pela modernização do país, apesar de sentirem em suas relações cotidianas as transformações que ocorreram, como no caso de muitas pessoas que viviam no interior de Santa Catarina e do Paraná. ${ }^{25}$

Com a ocupação do "Colosso" em 1915 pelos sertanejos do Contestado e preocupado com os prejuízos, Farquhar exige a presença de tropas federais, no que é prontamente atendido. Hermes da Fonseca mandara 8 mil soldados para a região; Wenceslau Brás outros tantos. Atendendo com presteza a solicitação, Wenceslau manda também para o Contestado dois aviões que entrarão para a História como responsáveis pelos primeiros ataques aéreos da América Latina. Em Contestado morreram mais de 20 mil pessoas. Farquhar dormia em paz.

Vez ou outra o cinismo de Charles Gauld e Farquhar afloram na biografia. Em uma das entrevistas do empresário ele afirma (em relação a ferrovia São Paulo-Rio Grande) ao historiador que com o tempo aprendera a lidar com a corrupção desenfreada no Brasil ( como a de Cuba, segundo ele, que por sinal era governada por uma junta militar norte-americana). Farquhar dizia que transitava com facilidade pelo Brasil e por ser Quaker demais não tinha estômago para lidar com coisas desagradáveis, deixando para que seus advogados e engenheiros a incumbência de dar as gorjetas aos políticos e funcionários brasileiros. A desfaçatez e o falso moralismo do empresário mereciam uma medalha. Nos fins dos anos 40 Farquhar recebe a Ordem do Cruzeiro do Sul.

A Brazil Railway volta os interesses para São Paulo. O estado era responsável por $70 \%$ do café produzido no Brasil e nosso país chegou a controlar três quartos do mercado mundial. Os serviços públicos encontravam-se bem mais organizados do que os da capital federal. Em 1907, dos cerca de 17.000 quilômetros de ferrovias brasileiras, os paulistas possuíam 4900 quilômetros, além de outros 2800 em projeto ou construção. Para Farquhar o que interessava eram as ferrovias. A mais importante delas era a Sorocabana. Com 1120 quilômetros de trilhos sinuosos ( um autor da época descrevia que trechos de $45 \mathrm{~km}$ poderiam alcançar $97 \mathrm{~km}$ para passar pelas fazendas do café),

\footnotetext{
${ }^{25}$ DALFRÉ, Liz Andréa. Outras narrativas da nacionalidade: o movimento do Contestado. Sociedade de amigos do museu paranaense. Curitiba. 2014. Pág. 157.
} 
tratava-se de um complexo de ferrovias mal construídas, pessimamente administradas (Farquhar descobre que as concessões paulistas rendiam $12 \%$ ao ano de juros aos proprietários contra os $6 \%$ que costumava receber) e de bitolas diferentes ( pelo menos 6 tamanhos distintos). Depois de uma longa negociação com lorde Balfour, proprietário da ferrovia e com apoio do presidente de São Paulo, Jorge Tibiriçá, o empresário americano compra a Ferrovia Sorocabana. Logo depois adquire $27 \%$ das ações da Companhia Mogiana e 38\% da Companhia Paulista de Vias Férreas, a mais lucrativa do Estado. Inteligentemente, ele manteve o prefeito da capital paulista e empresário, Antonio Prado, na presidência da empresa. Farquhar cria uma conexão interligando as três companhias na cidade de Campinas. A Brazil Railway passava a controlar quase 6 mil quilômetros de ferrovias na região mais importante do país. Farquhar estava em seu apogeu.

\subsubsection{Outros Projetos}

Mas não só de ferrovias vivia Farquhar. Em 1911 ele adquire um hotel de Antonio Prado. Funda a Companhia do Guarujá e contrata Ramos de Azevedo, que construiu um novo hotel com 220 apartamentos. O Grand Hôtel de la Plage foi inaugurado em 1912 e era composto de quatro grandes edifícios, alguns com três e outros com quatro andares. Era servido por elevadores e os apartamentos dispunham de terraços, dos quais se desfrutava a bela paisagem sobre o mar. Foi construído em madeira compensada importada da Geórgia. Os quartos eram dotados de água quente e fria, aparelhos telefônicos em cada apartamento e instalações de luxo. Havia áreas de ginástica sueca, dois parques e uma centena de cabines de banho. Farquhar apostava nos futuros cassinos que seriam construídos no Balneário do Guarujá. Em 1932, Santos Dumont suicidou-se em um de seus quartos. Em 1950 o prédio foi vendido e posteriormente demolido.

As serrarias de Farquhar espalhavam-se por três regiões: Belém, Mato Grosso e Sul do país. Em média produziam $4,7 \mathrm{~m}^{3}$ de madeira por hora ou cerca de $50 \mathrm{~m}^{3}$ por dia. Cada metro e meio estéril de madeira ( madeiras empilhadas com espaços vazios e restos de cascas entre elas) precisa de 6 árvores nativas para produzir toras. Para a obtenção de dormentes, a conta aumenta para 10 árvores nativas. Ou seja, somente nas serrarias do Sul derrubavam-se de 300 a 500 árvores por dia. Havia cerca de 800 trabalhadores somente nas serrarias catarinenses. A exploração desenfreada e destruidora, iniciada por Farquhar em 1911, estendeu-se até a década de 60 quando a 
floresta foi considerada praticamente extinta ( atualmente restam $0,8 \%$ da área original) e inviabilizada sua exploração. As frondosas árvores de araucária são essenciais para sombrear a terra, formando um guarda-sol natural que permitiu a expansão de diversas formas de plantas e animais em seu entorno ( entre elas a erva mate, também explorada pelo americano). Seu fruto comestível e saboroso era iguaria desde a época précabralina. As árvores são altas e podem viver por 300 a 500 anos. Trata-se de um dos grandes desastres ecológicos do Brasil o desaparecimento da Araucária.

Outra atividade do empresário Quaker foi a pecuária. Em 1853 o capitão Richard King se apossa de uma imensa terra no deserto do sul do Texas, lar dos cavalos selvagens. Nascia a maior fazenda de criação de animais e gado do mundo, o "King Ranch". Sua área atingiu 825 mil acres de dimensão ( aproximadamente 3,3 milhões de hectares, mais do que todo o estado de São Paulo). Farquhar quase cem anos depois se gabava de suas terras brasileiras: as diversas fazendas no Mato Grosso, Amapá e Sul do Brasil ocupavam 3,5 milhões de hectares ( só a de Descalvado no Mato Grosso possuía 1,6 milhões de hectares). O número de cabeças de gado chegava a 300 mil e o valor de mercado em 1946 era de US\$ 25 milhões ( em valores atuais seriam US\$ 500 milhões). A empresa criada para a exploração foi a Brazil Land, Cattle \& Packing Company (1909). Farquhar tinha em mente não só a exportação de carne, mas também o abastecimento interno num país em crescimento urbano acelerado. Enquanto a Swift e empresários locais montavam seus primeiros frigoríficos, Farquhar consegue um bom financiamento e constrói o frigorífico de Osasco na região do parque Continental, com os galpões ao lado do entroncamento da ferrovia Sorocabana de sua propriedade ( hoje estação Presidente Altino). Com a decretação final da recuperação dos negócios de Farquhar em 1919, ele se viu obrigado a vender o lucrativo frigorífico para a empresa Wilson, o concorrente da Swift.

Como visto, os projetos ferroviários de Farquhar tem um precedente histórico nos irmãos Rebouças. Interessante notar também que os investimentos de Farquhar no Brasil e América do Sul lembram muito as teorias geopolíticas posteriores de Golbery do Couto e Silva. Um corredor norte, formado por ferrovias ( Madeira-Mamoré) ${ }^{26}$, portos (Belém), hidrovias e embarcações que monopolizavam o comércio. Inclusive com a previsão ( nunca concretizada) de um corredor entre a Bolívia e o Chile, com a construção de um porto em Antofagasta e a ligação Atlântico-Pacífico. No cone sul, os investimentos na Argentina, Paraguai e Uruguai e a ideia de edificação do gasoduto 
boliviano também estavam presentes nos eixos geopolíticos propostos por Golbery ${ }^{27}$. As ferrovias paulistas e a Brazil Railway ${ }^{28}$ completavam o quadro. Um país que se quer potência deveria penetrar seu interior. Farquhar não imaginou Brasília, pois não teve tempo de conhecer Juscelino. Bajulador do poder que era, teria ganhado alguma concessão do presidente mineiro.

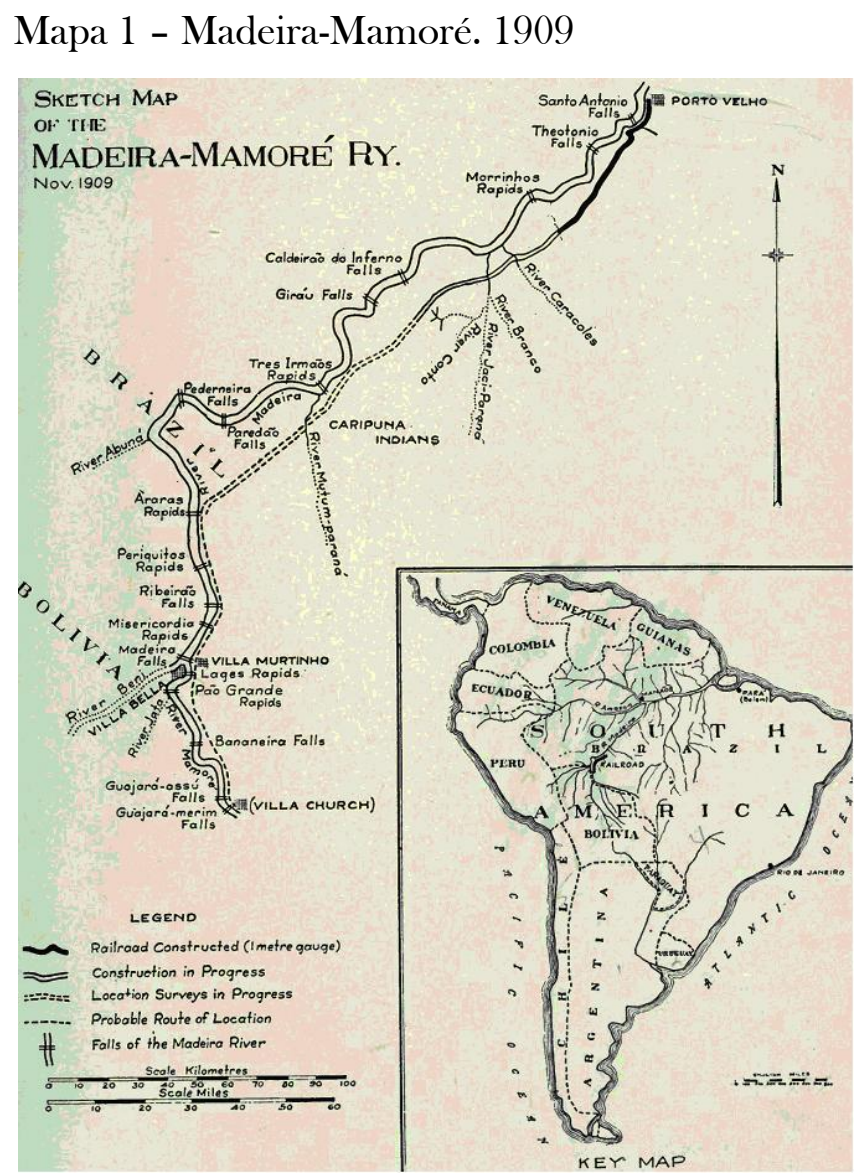


Mapa 2 - Estradas de ferro São Paulo-Rio Grande e Sorocabana

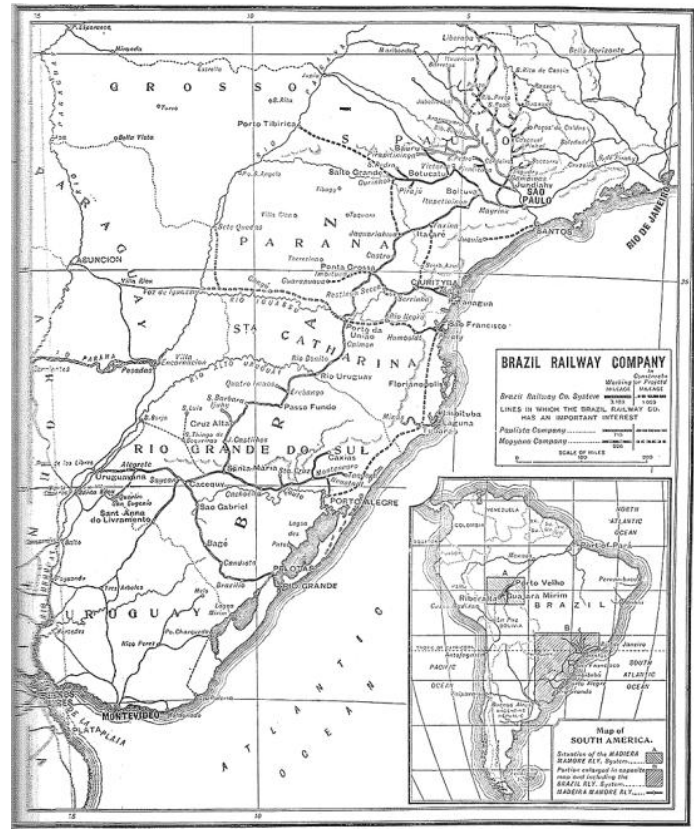

Mapa 3 - Eixos Geopolíticos - Golbery do Couto e Silva

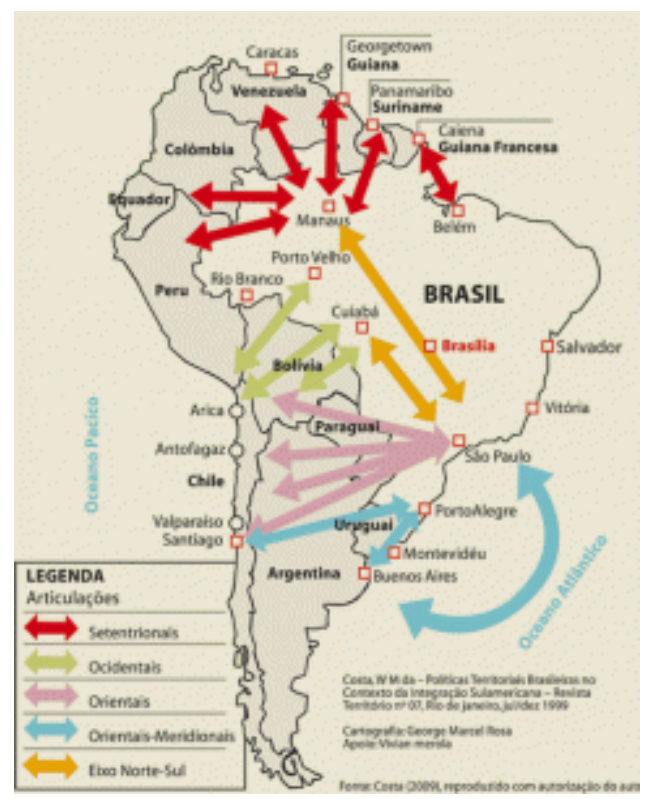

1.5. A Derrocada de Farquhar

Como Sísifo, Percival Farquhar ergueu sua imensa pedra repleta de ouro montanha acima entre 1905 e 1914. Chegando ao topo, tão rico quanto o egoísta Matarazzo ( nas palavras do americano), viu todo o esforço deslizar das suas mãos. Em 
três anos de árdua negociação sua imensa holding quase foi à bancarrota. Farquhar tentou segurar seu conglomerado até 1917. Afastado definitivamente, viu seus negócios e concessões serem encampados e partilhados até o fim da recuperação judicial (antiga concordata $^{29}$ ) em 1919. Gauld dá conta que Farquhar pouco recebeu por ter investido e acreditado tanto no Brasil. Os números citados passam de US\$ 3 milhões (US\$ 90 milhões atualizados) e cerca de 1 milhão de hectares de terras, ou seja, uma bagatela. Teve até de vender a mansão de Paris que possuía 14 funcionários antes dele se casar com Cathya Popescu em 1918.

Quais seriam os fatores da derrocada de nosso heroi quase sem nenhum caráter? Elencando-os:

I. Percival Farquhar podia ser considerado um visionário como empreendedor, excelente na concessão de crédito para seus projetos, mas foi um péssimo administrador das empresas que criou;

II. A dimensão da holding com projetos em várias regiões do país e espalhados pelos países vizinhos, aliados a diversificação dos negócios, exigia uma delegação de poderes. Farquhar era centralizador. Numa era sem transportes rápidos, eficientes e que atingiam pontos extremos; num tempo desprovido de uma comunicação instantânea, administrar uma ferrovia nos confins da Amazônia, fazendas no interior do inabitado Mato Grosso e tomar conta de serrarias em Santa Catarina era tarefa insana e hercúlea;

III. O enfrentamento com uma burguesia nacional xenófoba ao concorrente, entretanto amante do capital financeiro externo;

IV. Farquhar confiou demais num transporte que criou fortunas no século XIX. $\mathrm{Na}$ primeira metade do século XX, a indústria automobilística ( de cargas e passageiros), o transporte aéreo e a modernização tecnológica da navegação, transformaram a Ferrovia em apenas mais um meio de transporte, não o primordial;

V. A urbanização tem um custo: a massificação do acesso aos serviços públicos. O preço da prestação tem de acompanhar o inverso da lógica. Quanto mais passageiros

\footnotetext{
${ }^{29}$ O presidente Affonso Penna sanciona a Lei 2024/1908, reformando a Lei de Falências. A lei nova previa a figura da Concordata, em verdade um processo falimentar em que o devedor ( falido) ganhava um certo prazo para quitar as dívidas com os credores. Salvavam-se as empresas que eram viáveis; liquidavam-se as deficitárias. Concluído o processo de concordata, o falido estava isento das dívidas e recuperado para o mercado. É o que se observa nos dois artigos da Lei abaixo:

Art. 105. A proposta de concordata indicará todas as clausulas, as garantias reaes que o devedor porventura offereça e o modo por que devem ser pagos os credores; e será sempre por escripto, assignada pelo fallido, podendo vir logo apoiada por credores com a declaração do valor dos creditos e as firmas reconhecidas por tabellião.

(...)

Art. 111. A concordata, depois de passar em julgado a sentença de homologação, faz cessar o processo da fallencia, entregando-se ao concordatario todos os bens da massa, livros e papeis.
} 
de bondes, mais as tarifas devem ser baratas. Farquhar, pelos altos e constantes investimentos em atividades diversas não possuía preços competitivos em seus serviços;

VI. Os ciclos econômico-financeiros são de ascensão e queda. Os investimentos empresariais tem de observar esta lógica. Farquhar manteve por 10 anos uma política agressiva de tomadas de empréstimos, lançamento de ações e administração de caras concessões públicas. Quando aqui chegou, o Brasil acabara de sair da política recessiva de Joaquim Murtinho, o capital circulante crescia novamente e Rodrigues Alves gostava de obras públicas, afinal contava com a suspensão do pagamento de serviços da dívida externa proporcionado pelo $1^{\text {o }}$ funding loan. Em 1912, no auge dos negócios, as exportações de café e borracha estavam em queda. Hermes da Fonseca precisava pagar as dívidas. $\mathrm{O}$ mercado mundial se retraía, saindo da liquidez da primeira década. Com o dinheiro escasso seu custo subia. Em 1914, ano da derrocada, a Grande Guerra começara, Wenceslau Brás adotava o $2^{\circ}$ funding loan, Pandiá Calógeras, inimigo de Farquhar era o ministro da Fazenda. O dinheiro secou e o empresário Quaker continuava com suas ideias mirabolantes;

VII. Não se inventam mercados. Construir uma ferrovia de 350 quilômetros em meio à Floresta Amazônica há 100 anos era realmente ligar o 'nada a lugar nenhum'. Um investimento capitalista para produzir riquezas necessita de mercado consumidor. Criar uma frota de barcos no rio Amazonas em início de 1900 não era racional. Mesmo os projetos de colonização do Sul do país, em direção ao interior, eram equivocados. Neste país, como disse um historiador citado no século XVII, as pessoas ' andavam como caranguejos se arrastando pela costa';

VIII. O grande centro dinâmico da economia brasileira. A região da economiamundo na visão Braudeliana, era a cidade de São Paulo e algumas cidades próximas como: Santos, Jundiaí, Sorocaba, Itu e Campinas. O investimento capitalista para ter um retorno rápido e aproveitar o crescimento acelerado urbano-industrial dos primeiros anos do século XX deveria ser concentrado nessa localização. Farquhar investiu em várias regiões brasileiras, quase nunca ali;

IX. Farquhar era amigo de políticos brasileiros ( dos presidentes entre Rodrigues Alves e Getúlio, só teve um inimigo, Artur Bernardes). Possuía fácil trânsito nas grandes instituições financeiras europeias e era próximo de empresários poderosos. Apesar de sofrer ataques constantes da imprensa brasileira teve um grande admirador que veio a se tornar o nosso cidadão Kane, Assis Chateaubriand e seus Diários Associados. Difícil acreditar que não teve informações privilegiadas de negócios, dados 
que mostravam ser a borracha um investimento arriscado demais, ou mesmo dos conflitos de terras no Contestado. Ou Farquhar menosprezou seus contatos e fontes, ou acreditou muito na sua predestinação quacre;

X. Farquhar criou com a Brazil Railway Company e suas outras 38 empresas, uma pirâmide financeira. Um investimento inicial era garantido, tanto pelos juros ( em geral de 6\%), pagos pelo governo brasileiro, quanto a um novo negócio que vinha na sequência. De tal forma, que o segundo investimento amortizava parte dos empréstimos do primeiro, o terceiro amortizava o segundo e assim por diante. Até acabar a volatilidade do capital com a Guerra de 1914. Na prática, o empresário americano não possuía capital de giro, erro tão comum ainda nos dias de hoje;

XI. Ao menosprezar o trabalho, com exploração excessiva, com um certo desprezo pelas doenças e mortes dos trabalhadores, ou mesmo pela destruição de costumes sociais e culturais arraigados no brasileiro, o ianque que " gostava de dar ordens, exigia trabalho em fins-de-semana e feriados, não deixava os funcionários pararem enquanto não concluída uma etapa; era o mesmo que vivia nos salões, museus, teatros de Paris e Londres, que adorava equitação e colecionar quadros e vestia-se como um modelo de revista". Esse empresário que não delegava funções se ausentava dos negócios para se divertir e quando estava em meio ao chão de fábrica exigia demais de seus comandados. Para um Guinle isso era permitido por ser parte do folclore de um milionário excêntrico brasileiro. Para um ianque, era a morte.

Nas palavras do síndico-administrador Cameron Forbes:

Como administrador, encontrei uma confusão trágica. A Argentina necessitava de madeira; no entanto, foram necessários incríveis esforços para completar a linha transportadora de madeira e reabrir a grande serraria, por falta de fundos de emergência. Os aliados tentavam obter carne desesperadamente, e o frigorífico estava pronto. Mas foram feitos esforços sobre-humanos para levantar os 400 mil dólares necessários à compra de bois e vagões refrigerados. A fábrica em Osasco se pagou em 3 anos. A ‘cadeia dourada' de lucros proposta por Farquhar, que deveria vir de portos, ferrovias, madeireiras, pecuária, poderia ter sobrevivido intacta à guerra - desde que ele tivesse adotado métodos mais ortodoxos, em vez de partir para a expansão desenfreada, pagando preços excessivos e adquirindo 
concessões indesejáveis, que entraram em colapso quando o rio de dinheiro fácil secou. ${ }^{30}$

\subsection{O Primeiro Retorno ( 1919-1942)}

Farquhar não desistiu de sua Moby Dick. Um ano depois do fim da Grande Guerra e concluída a concordata de seus negócios, estava pronto para investir no Brasil novamente. Descobriu um imenso relatório produzido por Ernest Cassell, empresário que desde 1911 possuía a concessão para a exploração de minérios no interior de Minas Gerais.

A região entre as montanhas mineiras foi denominada posteriormente de Quadrilátero Central, pois a área mais rica em minérios de ferro e manganês do mundo até a descoberta da Serra dos Carajás (anos 70 no Pará), situava-se entre quatro grandes cidades num formato geográfico semelhante a um quadrado. Em 1916 Cassell vende a área para bancos estrangeiros. Epitácio Pessoa é procurado por Farquhar em 1919 e o empresário estava com a garantia dada pelos banqueiros estrangeiros para o negócio: um aporte de capital estimado em US\$ 82 milhões; com contratos fechados para a exportação de minérios para os Estados Unidos, Inglaterra e Alemanha ( as 3 nações mais industrializadas de então); além do apoio de Antonio Carlos Ribeiro de Andrada (ministro da Fazenda de Wenceslau Brás), depois presidente de Minas Gerais entre 1926-1930 e o nome escolhido para suceder Washington Luís em 1930, sendo preterido por Júlio Prestes de Albuquerque ( um paulista que provocou o racha na aliança do cafécom-leite e um dos fatores da revolução de 30). Nascia uma nova empresa de Farquhar, a Itabira Iron Ore Company Limited. Exploração de minérios, ferrovias e escoamento pelo futuro porto de Vitória. O Brasil não podia depender de um produto só, dizia ele. Um bicho de uma perna só. Talvez Farquhar desconhecesse o personagem mais famoso de nosso folclore, o Brasil era um saci.

Em 1921, o Tribunal de Contas da União vetou o projeto. Farquhar parte para longas negociações. Porém entre 1922 e 1926, encontra seu único inimigo na política da República Velha, Artur Bernardes. Ultra-nacionalista, patriota ao extremo ( tirando sua simpatia pela Companhia Belgo Mineira) e anti-industrialista como Joaquim Murtinho, Artur Bernardes lutou contra a concessão de Farquhar até os anos 40. O presidente brasileiro acreditava num relatório de pesquisadores americanos de 1910, famoso no

\footnotetext{
${ }^{30}$ GAULD, Charles. Farquhar, o último titã. Pág. 337
} 
período, de que não havia jazidas de minérios de ferro disponíveis no mundo e que com o consumo crescente do mundo industrializado, o correto era esperar alguns anos para a exploração, pois os preços internacionais do ferro iriam ter um valor exponencialmente maior. Enterra-se o futuro.

Com Washington Luís no governo a partir de 1927 e Antonio Carlos em Minas, Farquhar vê suas possibilidades crescerem. O acordo estava quase fechado. Inicia-se uma exploração pequena na região. Mas tudo reverteu no mercado financeiro em outubro de 1929 quando o quarto cavaleiro do apocalipse atingiu Farquhar. A crise da bolsa de Nova York encerrou as discussões por 2 anos. No ano seguinte, um novo revés: cai a República Velha, assume o ex-ministro da Fazenda de Washington Luís, Getúlio Vargas. Esfriam os negócios. Getúlio começa a utilizar a tática da gangorra com Farquhar: vez ou outra o recebe no Catete, trata-o com cordialidade, se mostra interessado na Itabira Iron e nos dias seguintes sinaliza aos opositores de Farquhar que não deixará o minério na mão de estrangeiros. Vem o $3^{\circ}$ funding loan em 1931 e aí, pode se considerar que a transação da Itabira Iron entrava em morte cerebral. Restava aguardar o desfecho. O golpe do Estado Novo e o redirecionamento fascista, nacionalista e estatizante de Getúlio iniciam o caminho para a encampação da empresa e dos negócios de Percival Farquhar em Minas Gerais. Era tempo da Companhia Vale do Rio Doce, uma empresa brasileira e do estado, além de fundamental para o desenvolvimento econômico do Brasil. O governador Benedito Valadares ( administrou Minas de 1933 a 1945) jamais visitou a região de Carlos Drummond de Andrade. Farquhar foi indenizado em US\$ 350 mil. Suas ideias foram seguidas à risca. Minas agora era um corpo de ferro dotado de um coração de ouro e um gostinho genuíno de café brasileiro.

\subsection{A Última Esperança ( 1944-1952)}

O ocaso empresarial de Farquhar talvez tenha sido seu projeto mais rentável e conservador nas ações. No seu octagésimo aniversário em 19 de outubro de 1944 anuncia seu último negócio no Brasil: a construção de uma siderúrgica distante cerca de $100 \mathrm{~km}$ de Itabira, devidamente rodeada por uma cidade operária. O Brasil possuía apenas a Companhia Siderúrgica Nacional (CSN) em Volta Redonda (RJ). Uma estatal construída por Getúlio Vargas. A empresa se denominava Acesita (Aços Especiais Itabira). Curiosamente, a última empresa de Farquhar foi a primeira a ter um nome totalmente em português. Getúlio não impôs restrições, ao contrário estabeleceu boas 
relações com Farquhar. Por 8 anos a empresa foi administrada de forma eficiente e lucrativa por Farquhar. A Acesita possuía:

[um] alojamento temporário dos funcionários que ficou pronto em 1947, tendo início a construção da cidade empresa permanente. Entre 1948 e 1949, a construção do complexo de alto-forno foi acelerada e concluída. Podia produzir 200 toneladas diárias e necessitava, quando operando a plena capacidade ( o que só aconteceu após alguns anos), de mais de 160 toneladas de carvão, extraídos dos 14,5 hectares de florestas da Acesita. Farquhar fazia questão de que as árvores derrubadas fossem cuidadosamente substituídas por novas mudas, principalmente de eucalipto, que tem maturação rápida, assegurando fornecimento ininterrupto de carvão no caso de não ser possível trocar o minério de ferro da Acesita pelo coque, o carvão mineral que vinha do exterior. Também em 1949 forma erguidos os edifícios de aço para acomodar o laminador americano de 24 polegadas que Farquhar tinha comprado de segunda mão em 1943. O edifício principal que abrigaria o conversor Bessemer, o misturador e os fornos elétricos estavam em construção. O canal e os reservatórios ficaram prontos. A cidade da Acesita abrigava quase 6 mil habitantes. ${ }^{31}$

Entre 1951 e 1952, bastante debilitado pelo Mal de Parkinson, o empresário norte-americano Percival Farquhar entrega a maioria das ações da Acesita para o Banco do Brasil. Em 30 de outubro de 1952, Farquhar e Cathya estavam na cobertura de propriedade do casal, no deslumbrante Edifício Biarritz, localizado na praia do Flamengo, número 268 (Em 2013, o edifício foi eleito o endereço mais charmoso do Rio de Janeiro pelo jornal 'O Globo'). Nesse palacete de rara beleza arquitetônica, Farquhar olhou pela última vez para a orla da praia à sua frente, respirou o ar úmido e salgado da cidade maravilhosa, verteu seus olhos a nordeste e admirou pela vez derradeira o Pão de Açúcar, direcionou então seu corpo para sudeste, fitou o Cristo Redentor de braços abertos, convidando a todos para admirar e abençoar o país. Riu internamente com a crença nacional de que Deus é brasileiro e partiu da terra que adotou com fibra e energia. No ano seguinte estava num hospital de Nova York e acaba por fazer uma cirurgia cerebral experimental numa tentativa de estancar a dor causada pelo Parkinson, mas não resiste. Em 4 de agosto de 1953 falece o maior empresário da

${ }^{31}$ GAULD, Charles. Farquhar, o último titã. Pág. 424-425 
primeira metade do século XX no Brasil, o quacre norte-americano Percival Farquhar. Repleto de idiossincrasias como bem quer a História. Um personagem tal como tudo nesse país: amado ou odiado sem tréguas.

Encerro o capítulo com as palavras de Isaac Deutscher:

O historiador não pode deixar de ser determinista ou de se comportar como tal, se não o for; ele não terá terminado inteiramente seu trabalho se não tiver mostrado causas e efeitos tão íntima e inteiramente entrelaçados na textura dos eventos, que nenhuma lacuna apareça, ou seja se não tiver demonstrado a inevitabilidade do processo histórico com o qual se preocupa. ${ }^{32}$

Nosso defunto-autor, um homem de império, um colonizador norte-americano que se apropriou de todas as formas necessárias para criar um grande conglomerado econômico. Formas como as alianças políticas espúrias, financiamento externo, monopólios de mercados diversos, exploração do trabalho, um sem número de violências e um empreendedorismo de quem tem a certeza que jamais dormirá no frio e no silêncio. Esse personagem de muita saúde nos guiará por uma história de permanências econômicas e políticas entre convulsões sociais de um país em movimento para uma industrialização e urbanização tardias.

${ }^{32}$ DEUTSCHER, Isaac. Stálin: uma biografia política. Editora Record. Rio. 2006. Pág 17 


\section{CAPÍTULO 2 - REPÚBLICA VELHA ( 1889 - 1914)}

Num de seus contos pouco conhecidos, Machado de Assis narra a história de Lopes. Anos antes do início da história, o narrador e Lopes estiveram juntos num tribunal como jurados. A votação ia apertada e, decidindo a contenda, a personagem Lopes justifica seu voto pela condenação: “Quer sujar? Suja-se gordo. Por 2500 réis deve pagar". O bruxo do Cosme Velho passa a refletir sobre o sentido da frase e nada descobre. Eis então que um novo julgamento aparece e tem o narrador novamente como jurado. Qual não é a surpresa dele quando o acusado é o tal de Lopes. Falsidade ideológica e desvio de 110 contos de réis. O advogado de defesa faz uma defesa brilhante, pautada na passagem bíblica “ não julgueis para não ser julgado”. O narradorpersonagem tem certeza da culpa do Lopes, mas a votação é retumbante: 9 votos pela absolvição e 2 pela condenação. Finalmente ele entende o sentido de "Suja-se gordo".

Percival Farquhar enfrentou uma oposição sem tréguas entre 1905 e 1913, período dos seus primeiros e mais volumosos investimentos em desenvolvimento industrial no Brasil. Imprensa, políticos, empresários nacionais e os trabalhadores de seu Syndicato foram incansáveis na luta contra o invasor estrangeiro. O jornalista Alberto de Faria, servindo a interesses da burguesia nacional escreveu no Jornal do Commercio:

Aqui, um syndicato, ou antes, um homem detêm em suas mãos todos os meios de transporte de mais de metade da população brasileira, atravessa-se na entrada dos nossos melhores portos, monopoliza os tramways,a luz, a força na Capital e em varias cidades, obtem de uma assentada e grátis 60.000 kilometros quadrados no Pará, na fronteira; emfim ( para antecipar o futuro de três a cinco annos, apenas) fica dono, senhor, possuidor ou usofructuario de todo o Brasil! E todos se calam! Não cansados de dar ao mundo os mais tristes espectaculos, vamos offerecer este, com seus perigos e humilhações, - uma nação de 25 milhões de homens enfeudados ao Sr. Farquhar. 33

Empresários como Guilherme Guinle e escritores como Monteiro Lobato colaboraram para criar a fama demoníaca do investidor estadunidense. O objetivo desta

\footnotetext{
${ }^{33}$ Jornal do Commercio. 19 de outubro de 1912. "O truste é o inimigo"
} 
tese não é ser um panegírico de Farquhar, menos ainda de ser uma hagiografia $a$ posteriori. A propalada existência de uma burguesia nacional originada do capital mercantil do café, quatrocentona, quase uma nobreza feudal em terras tropicais, é duvidosa. Awad e Bresser Pereira ${ }^{34}$ em pesquisa realizada nos anos 60 demonstram que $84,3 \%$ dos grandes empresários da época ( vivos ou mortos) eram de imigrantes. Desses 34,7\% eram italianos como os Matarazzo, Martinelli e Scarpa. O número de empresários alemães no Brasil eram quase os mesmos dos nacionais. Os autores ainda citam o estudo de Fernando Henrique Cardoso sobre História Empresarial com conclusões próximas as deles.

Monteiro Lobato esteve algum tempo nos Estados Unidos nos anos 20. Admirou-se com o empreendedorismo do capitalismo norte-americano. Com a ideia liberal de que a riqueza de um país vem da somatória dos esforços individuais e da livre iniciativa. Lobato não só reviu suas teses nacionalistas contra Farquhar, como em apêndice da biografia do empresário estadunidense escrita por Charles Gauld, este nos revela que o criador do Sítio do Pica-pau Amarelo estava a escrever uma biografia de Farquhar nos anos 40.

Como diz Crouzet em relação a imprensa ( do início do século XX):

“ Nesta civilização de massas, em que o papel destas é tão considerável, os interesses que dominam os partidos e os governos dirigem a opinião pública por intermédio do jornal." 35

A luta pela liberdade de imprensa era a luta contra os governantes e seus financiadores. Porém, a imprensa tornou-se um grande negócio e uma oportunidade de se obter lucros elevados sem muitos riscos. Os custos de impressão, distribuição e produção de notícias cresceram rápido demais. O preço da capa e da banca não cobriam as despesas. O jornal necessitava de novas fontes de financiamento, parte dela viria dos empresários e políticos interessados em "vender sua causa" para a opinião publica e a outra parte dos recursos era trazida pela publicidade. A liberdade de expressão era relativa. Os textos saíam formatados de acordo com os padrões determinados pelo editor-chefe e este por sua vez, servia a interesses do capital. Criticar Farquhar era agradar aos anunciantes. Eram brasileiros tão patriotas — como Guinle —, que preferia paralisar a obra da Usina de Lajes e ver o Rio sem eletricidade por anos, do que entregar

\footnotetext{
${ }^{34}$ AWAD, Zaira Rocha \& BRESSER PEREIRA, Luiz Carlos. Empresários, suas origens e as interpretações do Brasil. Trabalho apresentado ao I Congresso Brasileiro de História Econômica e à II Conferência Internacional de História de Empresas. Unicamp, Campinas, 8-9 de setembro, 1993.

${ }^{35}$ CROUZET, Maurice. História geral das civilizações. Volume 15. Bertrand Brasil. São Paulo. 1996. Pág. 126
} 
a exploração do serviço a Light \& Power, mesmo que para isso tivesse de inventar ( em conluio com a imprensa), que a crise de malária na Capital em 1907 era responsabilidade das obras da usina de Farquhar. Nada diferente de William Randolph Hearst inventar um ataque espanhol em Cuba para obrigar os Estados Unidos a declarar guerra. As classes dominantes se parecem entre si.

Percival Farquhar não foi santo. Corrompeu, explorou trabalhadores, matou rebeldes, deu golpes e fez falcatruas, mas não era o único. Como diria o advogado de Lopes: " não julgueis para não ser julgado".

Quanto aos políticos? Sigamos um pouco da História da República Velha.

\subsection{Breviário Político}

\subsubsection{Prudente de Moraes (1894-1898)}

Prudente de Moraes foi o primeiro presidente civil de nossa história. Também o primeiro paulista. Governou em meio a sobressaltos econômicos, guerras, uma licença-saúde e até uma risível tentativa de assassinato político.

Rodrigues Alves foi nomeado ministro da Fazenda e Joaquim Murtinho ministro da Indústria, Viação e Obras Públicas. Ambos foram peças fundamentais nos embates de política econômica por quase uma década.

Por dois anos Rodrigues Alves comandou o Tesouro Nacional permitindo a emissão de moeda, seja para cobrir os prejuízos dos cafeicultores com as constantes desvalorizações cambiais, ou para financiar a resistência da União aos custosos conflitos civis que grassavam a República Velha, entre eles a Guerra de Canudos.

Joaquim Murtinho, por sua vez, tecia profundas críticas a essa expansão papelista e defendia um controle maior sobre as emissões. Ganhou a confiança de Campos Sales para, no governo seguinte, introduzir as medidas drásticas de contenção de despesas, aumento de impostos e redução do capital circulante no país. Tal condução econômica permitiu ao ministro matogrossense receber um estado falido e endividado em 1898 e entregar uma economia saudável, saneada e com dívidas alongadas ao sucessor na presidência: o Dr. Rodrigues Alves, como gostavam de denominá-los os jornais de época.

Doente, o presidente licenciou-se do cargo em dezembro de 1896. Seu vice, Manoel Vitorino, imediatamente trocou todo o ministério. Bernardino de Campos substituiu Rodrigues Alves. Os custos de Canudos se elevavam. Vitorino acreditava que 
Prudente jamais reassumiria. Governou como se nunca mais tivesse de deixar o Catete. O presidente, sentindo-se golpeado politicamente, teria dito ao novo ministro Bernardino de Campos, ao ser questionado sobre a aprovação do novo ministério de Vitorino: " não trato com canalhas". E os canalhas insistem em voltar. Ainda fraco e doente, menos de 4 meses depois, Prudente reassume. Teria de enfrentar os radicais jacobinistas e alguns ex-partidários de Floriano Peixoto. Em 5 de Novembro de 1897, o soldado florianista Marcelino Bispo tenta lhe matar. A descrição do atentado é hilária:

O presidente trazia a cartola na mão direita; as bandas tocavam o hino nacional. Foi quando surgiu-lhe de súbito à frente, num salto de felino, um soldado no peito apontando-lhe uma pistola. Desviou-se num gesto rápido para a direita, afastando com a cartola o cano da arma. ${ }^{36}$

Um simples golpe de cartola. Esta foi a reação do alquebrado presidente para defender sua vida de um perigoso felino. Mas a caneta agiu com mais propriedade. Prudente decretou o estado de sítio, diversos políticos acusados de jacobinismo e conspiradores foram condenados ao desterro e ao isolamento político. Entre eles, o vice Manoel Vitorino. Posteriormente, a maioria recebeu habeas corpus e foram anistiados. O jacobinismo perdera suas últimas forças.

Entre 1894 e 1900, período dos governos de Prudente e Campos Sales, o jornal "A Gazeta de Notícias" publicou diversas crônicas de Machado de Assis. Numa delas, após analisar a morte de uma bailarina russa, o genial escritor procura sondar a alma brasileira ao defender que:

Mistérios nunca nos aborreceram; a prova é que folgamos agora diante de dois mistérios enormes, dois verdadeiros abismos (insondáveis). Sempre gostamos do inextricável. Este país não detesta as questões simples, nem as soluções transparentes, mas não se pode dizer que as adore. A razão não está só na sedução do obscuro e do complexo, está ainda em que o obscuro e o complexo abrem a porta à controvérsia. ${ }^{37}$

Um dos mistérios seria o bacilo vírgula. O vibrião do cólera, descoberto anteriormente na Europa, por Koch, acabara de ser isolado em laboratório brasileiro pelo cientista Adolfo Lutz em 1894, confirmando a presença da doença no país. O bacilo navegava pela cultura de bactérias como uma embarcação. Foi o suficiente para

\footnotetext{
${ }^{36}$ SILVA, Hélio. Prudente de Moraes. Editora Três. Rio. 1983. Pág. 116

${ }^{37}$ Obra Completa de Machado de Assis. Rio de Janeiro: Nova Aguilar, Vol. III, 1994. Pág. 222
} 
Machado exercer suas ironias e comparar o navegar do bacilo vírgula com o movimento do câmbio, no caso da crônica, o segundo mistério. O bruxo do Cosme Velho descreve a febre papelista do Encilhamento no início da República:

Os do encilhamento aturdiram por alguns dias ou semanas; mas desde que se descobriu que o dinheiro caía do céu, o mistério perdeu a razão de ser. Quem, naquele tempo, pôs uma cesta, uma gamela, uma barrica, uma vasilha qualquer, no luar ou às estrelas, e achou-se de manhã com cinco, dez, vinte mil contos, entendeu logo que só por falsificações é que fazemos dinheiro cá embaixo. Ouro puro e copioso é que cai do eterno azul. (...)

Há quem queira filiar o câmbio aos costumes do encilhamento. A pessoa que me disse isto, provavelmente soube explicar-se; eu é que não soube entendê-la. É uma complicação de dinheiro que se ganha ou se perde, sem saber como, anonimamente, com resignação geral de baixistas e altistas. Um embrulho. Mas há de ser ilusão, por força. Quem se lembra daqueles belos dias do encilhamento, sente que eles acabaram, como os belos dias de Aranjuez. Onde está agora o delírio? onde estão as imaginações? As estradas na lua, o anel de Saturno, a pele de ursos polares, onde vão todos esses sonhos deslumbrantes, que nos fizeram viver, pois que a vida es sueño, segundo o poeta?(... $)^{38}$

Evidencia-se aqui que os assuntos políticos, sociais e econômicos do Brasil não são marginais na obra de Machado. Ao contrário, por meio das alegorias ele camufla críticas ao regime republicano, assim como fizera com o Império. A maestria do escritor estava em ser aceito pelas elites, mesmo tecendo comentários mordazes como estes sobre o câmbio, o Encilhamento e a febre papelista. Talvez porque a sutil ironia não era percebida pelos sábios de então. Machado de Assis funda a Academia Brasileira de Letras três anos após a crônica, durante o governo de Prudente de Moraes. A sociedade brasileira urbanizava-se e adquiria a face de um mundo industrializado, cientificista, racional, mas - contraditoriamente — profundamente atrasado em suas relações políticas e sociais.

A violência do Estado foi uma das marcas da República Velha. Até a Revolta da Armada, a luta ocorria entre grupos descontentes com o poder. Era uma luta

\footnotetext{
${ }^{38}$ Obra Completa de Machado de Assis. Rio de Janeiro: Nova Aguilar, Vol. III, 1994.pág 222 e 223
} 
entre as elites, ou entre grupos políticos excluídos. Canudos inaugurou uma nova fase de contestação: a população contra o Estado.

Canudos ou Belo Monte (na visão dos vencidos), pode ser analisada pela visão datada, porém maravilhosa, construída por Euclides da Cunha. Outra interpretação é o discurso laudatório de uma vitória da civilização contra a barbárie, típico das elites brasileiras. Poucos percebem a função da religiosidade ( e de seus sentidos) tanto para Canudos, quanto para as camadas pobres da sociedade brasileira.

A partir da segunda metade do século XIX, o Nordeste e, especialmente o Ceará, sofreu com secas sucessivas que derrubaram a produção agropecuária e empobreceram mais ainda o sertanejo. Cercado pelo latifúndio, pressionado pelas autoridades políticas e eclesiásticas, o sertanejo encontrava na religiosidade uma forma de expiação dos pecados e, também, uma esperança de sobrevivência social. Nesse sentido, a religião popular não se limitava a meras crendices ou sandices do sertanejo pobre, aproximava-se de um instrumento para o entendimento e o enfrentamento das adversidades oferecidas pela vida miserável no interior nordestino.

O beato Antonio Vicente (conhecido como Conselheiro) fazia parte desse universo mental do sertanejo, distante, portanto do 'louco messiânico' retratado por parte dos teóricos.

A trajetória de Antonio Conselheiro começa em 1880, quando sai de Quixeramobim (CE) e começa a pregar pelo sertão nordestino erguendo cemitérios (afinal os pobres não podiam ser enterrados no cemitério da Igreja e nem existiam cemitérios públicos) e igrejas (com 'i' minúsculo, pois trata-se da igreja popular e não a com 'I' maiúsculo, a igreja da cúria romana elitista). Essa é a primeira subversão do Conselheiro: a oposição ao clero romano por uma religiosidade popular.

Num certo sentido, a Revolta do Contestado anos depois repetirá a forma de organização. Os líderes José Maria e João Maria eram denominados de "monges", autorizados pela própria Igreja da região a conduzir os ritos da igreja popular.

Só em 1892 que surge o 'arraial de Canudos'. Depois de muito procurar, os seguidores de Conselheiro se fixam numa região no interior da Bahia, de localização geográfica privilegiada para a defesa em caso de invasão (já esperada pelo Conselheiro, não como profeta, mas como um lúcido estrategista).

Produzindo num sistema de cooperativas, realizando trocas comerciais com as cidades vizinhas e chegando a contar com algo entre 12 a 15 mil habitantes, Belo Monte ergueu mais de duas mil casas e uma imponente igreja, só derrubadas a 
dinamite e fogo pelas quatro grandes e agressivas expedições do exército brasileiro. Estava aí a segunda subversão: uma organização econômica baseada na pequena propriedade, desafiando a lógica do latifúndio.

A auto-organização do arraial, centralizada no seguimento aos preceitos religiosos, teve um caráter 'sebastianista' - a crença espalhada pela cultura portuguesa no retorno do infante-rei português D. Sebastião, morto na batalha de Alcácer-Quibir (1578) - , para construir um novo paraíso terrestre. Belo Monte seria, em certo sentido, uma possibilidade real de um 'paraíso' livre do latifúndio, do poder autoritário da Igreja romana, do governo republicano ( daí seu pretenso monarquismo, em verdade um conservadorismo) e da relação patriarcalista dos coronéis nordestinos. A terceira subversão: Belo Monte mostrava que era possível construir uma sociedade sem as relações de dependência política, econômica e cultural exercida pelos coronéis.

Um quarto motivo seria o caráter monarquista da rebelião. Conselheiro não era um político, nem Canudos era monarquista. Sua luta era contra as injustiças sociais da sociedade nordestina e contra a excessiva precarização econômica e desprezo social a que eram assolados os sertanejos pelos governos republicanos. Dentro do próprio governo baiano, a elite que comandava a Província em 1892-1897 era quase toda ela egressa dos ideais monarquistas. $\mathrm{O}$ enfrentamento em Canudos serviu muito mais como uma forma de estabelecer o novo regime republicano e de fortalecer a posição do exército dentro da sociedade brasileira.

O conflito estoura em 1896 com o boicote de um comerciante em entregar mercadorias já pagas pelo Arraial. Conselheiro determina o resgate da mercadoria e derrota as tropas municipais. Estava aberto o precedente. Quatro incursões militares foram realizadas com utilização de dezenas de milhares de soldados do exército (muitos abandonavam a farda e se juntavam aos seguidores de Conselheiro), canhões, armas pesadas, dinamites e todo o arsenal de crueldades impingidas aos habitantes de Belo Monte. Depois de extenuar os conselheiristas pela fome, pela violência, pelo isolamento no Rio Vasa Barris (única fonte hídrica dos sertanejos), no início de outubro de 1897 o arraial era posto abaixo como bem retrata a 'ordem do dia' abaixo:

Durante a noite foram lançadas noventa bombas de dinamite, cujo efeito foi esplêndido, maravilhoso causando ao inimigo enormes perdas. Uma delas caiu em um hospital de sangue, ateando-se violento incêndio. Era de constranger o coração o quadro que se observava: 
gritos lancinates de angústia, de dor e de desespero! Crianças a chamarem por suas mães e por seus pais, mulheres que, feridas, mortas de fome e de sede, se debatiam com as chamas, onde centenas delas encontravam seu túmulo!'(Canudos, Ordem do dia, 01/10/1897)

Canudos representou uma revolta popular que desafiava a maior parte dos poderes dominantes da sociedade brasileira: o latifúndio, o clero romano, o coronelismo e o exército brasileiro. A sociedade de Belo Monte era uma proposta de transformação da realidade social e cultural do sertanejo, portanto, sediciosa e consequentemente passível de destruição total, como bem ordenou o presidente Prudente de Moraes: "Não se deve deixar uma pedra do arraial de Canudos".

Hobsbawm em "Rebeldes Primitivos" considera que movimentos sociais como o de Canudos ( não analisado por ele no livro citado) estariam nas origens duma aquisição de consciência política pelos excluídos. Não eram marginais, menos ainda bandoleiros, tratavam-se de populações pobres e excluídas do processo de modernização política, econômica e social dos fins do século XIX, rebeldes que lutavam em defesa de uma revolução milenarista para a restituição da ordem perdida. Para o historiador inglês:

Nos movimentos sociais europeus primitivos, a forma desempenha um papel muito mais importante, embora, obviamente, seus membros não levem em conta a clara distinção moderna entre forma e conteúdo. Nenhum destes elementos pode existir sem o outro.

(...)

Palavras como "primitivo" e “arcaico" não devem, no entanto, tirar-nos do caminho correto. Os movimentos discutidos neste volume tem todos por trás deles uma certa evolução histórica, porque pertencem a um mundo velho e de proximidade com o Estado (ou seja, soldados e policiais, prisões, fiscais de tributos, talvez funcionários) com diferenciação e exploração de classe, obra de latifundiários, comerciantes e afins, e com o poder local. Os laços de solidariedade devidos à família ou da comunidade, o que, combinado ou não com vínculos territoriais são a chave para compreender aquelas sociedades geralmente descritas como 'primitivas', que não deixaram de existir. Mas enquanto elas ainda tem uma importância considerável, elas deixaram de ser a principal forma de defesa do 
homem contra a arbitrariedade do mundo em torno dele. A discriminação entre estas duas fases dos movimentos sociais "primitivos" não pode ser a luta final, mas o que poderia ser feito. $^{39}$

Prudente de Moraes herdou uma economia endividada de Floriano Peixoto. Tanto Rodrigues Alves, quanto Bernardino de Campos, ministros da Fazenda de seu governo, foram incapazes de sanear a economia do país. Mais do que isso, as constantes quedas internacionais dos preços do café eram acompanhadas de safras crescentes do produto no Brasil ( que detinha pelo menos $60 \%$ do mercado mundial), condição esta piorada pelas tendências altistas do câmbio, agravando mais ainda o quadro financeiro do país.

A Guerra de Canudos, longa e dispendiosa, obrigou Prudente de Moraes a novos empréstimos externos e ao emissionismo, tão rejeitado pelos Metalistas. Joaquim Murtinho, ministro da Viação produz um relatório contundente contra a situação caótica da economia brasileira. Era contra o Papelismo, detrator da "Indústria artificial”. O Brasil precisava defender o café e tomar medidas amargas:

A nossa organização industrial tem seguido nestes últimos anos uma marcha anômala, irregular e profundamente viciosa.

Duas grandes causas tem contribuído para esse resultado: uma compreensão falsa do patriotismo e uma pletora não menos falsa de capitaes.

A idéa errônea e anti-social de que a grandeza industrial de nossa pátria depende sobretudo da nossa libertação, cada vez mais completa, dos produtos da indústria extrangeira, foi provocando a aspiração de estabelecer empresas industriaes de todos os gêneros, para se conseguir realizar aquelle desideratum pseudo-patriotico.

\footnotetext{
${ }^{39}$ HOBSBAWM, Eric. Rebeldes primitivos - estúdio sobre las formas arcaicas dos movimentos sociales en los siglos XIX y XX $3^{\text {a }}$ edição. Editorial Ariel. Espanha. 1983. Págs. 12, 13 e 239. Tradução Nossa do Original: "En los movimientos sociales primitivos europeos la forma desempeña un papel mucho más importante, aunque evidentemente sus miembros no tenían en cuenta la clara discriminación moderna entre la forma y el contenido. Ninguno de ambos elementos puede existir sin el otro.(...) Palabras como las de «primitivo» y «arcaico» no deben, sin embargo, desencaminarnos. Los movimientos discutidos en este volumen tienen todos detrás de sí no poca evolución histórica, porque pertenecen a un mundo familiarizado de antiguo con el Estado (es decir, soldados y policías, cárceles, cobradores de contribuciones, acaso funcionarios), con la diferenciación y la explotación de clase, obra de terratenientes, mercaderes y afines, y con ciudades. Los vínculos de solidaridad debidos al parentesco o a la tribu, que, combinados o no con vínculos territoriales, son la clave para la comprensión de las que suelen calificarse de sociedades «primitivas», no han dejado de existir. Pero aunque tienen todavía una importancia considerable, han dejado de ser la forma primordial de defensa del hombre contra las arbitrariedades del mundo que le rodea. La discriminación entre estas dos fases de los movimientos sociales «primitivos» no puede llevarse al extremo, pero creo que debe hacerse."
} 
De outro lado a grande ilusão financeira, de que mal acabamos de sahir, fez-nos acreditar na existência de capitaes enormes, de riquezas inexgottaveis e mais que suficientes para realizar aquella aspiração. ${ }^{40}$

Antes mesmo de encerrado o governo, com o apoio de Campos Salles, foi negociado o funding loan. Quando assume o presidente Campos Salles nada mais lógico do que Murtinho ocupar o ministério da Fazenda. No último capítulo serão aprofundados os relatórios produzidos entre 1898 e 1902 pelo ministro Joaquim Murtinho. Nosso oligarca de muita saúde.

\subsubsection{Campos Salles (1898-1902)}

Durante o quatriênio de Campos Salles nasceram dois símbolos da cultura popular do país: o futebol e o samba.

Num abril de 1895 Charles Müller organiza uma pelota reunindo funcionários de três firmas inglesas paulistanas: a São Paulo Railway, a Gaz Company e o London Bank na várzea do Carmo. Era a primeira partida de futebol no país.

Praticado amadoristicamente e quase sempre por imigrantes pertencentes à elite ( branca) do Brasil, nos primórdios o futebol estava muito longe do fenômeno de massas que se tornou por aqui décadas depois. Os cinco primeiros times de foot ball do estado - o S.C.Germânia dos imigrantes alemães e os ingleses S.C.Internacional, São Paulo Athletic Club, A.A. Mackenzie; além do 'brasileiro' C.A.Paulistano com Bento Bueno e Martinho Prado entre os diretores —, organizaram a Liga Paulista de Football em dezembro 1901 e no ano seguinte realizaram o primeiro campeonato do país: o Campeonato Paulista de 1902, vencido pelo São Paulo Athletic Club. A sede do clube localizada numa travessa Visconde de Ouro Preto com a rua da Consolação, foi adquirida por Veridiana da Silva Prado ( que posteriormente alugou em outra região o terreno do velódromo para seu neto Antonio Prado Junior edificar o Clube Atlético Paulistano). Na final, em outubro daquele ano, Charles Müller fez os dois gols do azul e branco na vitória contra o Paulistano.

\footnotetext{
${ }^{40}$ MURTINHO, Joaquim. Relatorio apresentado ao presidente da republica dos estados unidos do Brasil pelo ministro do estado dos negócios da indústria, viação e obras. Imprensa Nacional. Rio. 1897. Pág. XII
} 
Eram os últimos dias de Campos Salles ${ }^{41}$ na presidência da República. Além do futebol, outro elemento essencial da cultura popular brasileira nascia naquele quadriênio. Chiquinha Gonzaga compõe “Oh Abre-Alas” em 1899, a primeira marchinha de Carnaval. Segundo Edinha Diniz, biógrafa da compositora e maestrina carioca, antes das escolas de samba:

[ O cordão] era para as massas o correspondente do clube político para o senhor, e até mesmo das sociedades carnavalescas para os mais bem situados socialmente(...) o crescimento dos cordões carnavalescos se dá paralelo à campanha abolicionista. É a fase das agremiações, do desenvolvimento de um estilo de vida mais urbano, de uma mais intensa participação social (...) [grupos] se reuniam com antecedência para se divertir e criticar os fatos que mais os impressionavam (...). Cada cordão tinha suas cores definidas e usava instrumentos de percussão.(...) Na rua dançava-se ao som de baterias cadenciadas e entoava-se canções monótonas, bruscas pela pobreza melódica e sem harmonia. (...) No final do século os cordões já entoavam algumas canções, ora de empréstimo, ora improvisadas, e era comum se utilizarem de uma marcha, com versos pedindo para abrir alas e apresentando o nome do cordão. (...)42

Chiquinha Gonzaga estabeleceu o ritmo e deu sentido as letras dos futuros sambas, quase duas décadas antes do aparecimento de "Pelo telefone" de Donga, o primeiro samba gravado no país.

Num país de completo distanciamento entre a classe dominante e o povo comum, seria muito exigir de Campos Salles algum entusiasmo, sequer conhecimento dos sports ou do carnaval. A coincidência é apenas cronológica.

Depreende-se também a origem distinta entre futebol e carnaval. O primeiro apareceu na São Paulo do café, praticado em sua maioria por estrangeiros, um esporte regrado em linhas determinadas e geométricas, de origem inglesa, cresceu de cima para baixo, à medida que as camadas populares começaram a praticá-1o ${ }^{43}$. Quanto

\footnotetext{
${ }^{41} 1900$ marca o ano da fundação do primeiro time de futebol do interior paulista, a Associação Atlética Ponte Preta, da mesma terra do presidente Campos Salles.

${ }^{42}$ DINIZ, Edinha. Chiquinha Gonzaga: uma história de vida $8^{a}$ ed.. Rosa dos ventos. Rio. 1984. Trechos esparsos.

${ }^{43}$ Até os dias atuais, a agremiação de maior torcida do Brasil é o Clube de Regatas Flamengo. Segundo estatísticas extraoficiais de diários esportivos (2014), o time carioca tem cerca de 17,5\% de preferência dos que torcem por algum time em todo o país. O Sport Clube Corinthians Paulista ( nome de origem inglesa) tem cerca de 14,2\%. Porém, fora de seu estado de origem, os cariocas tem quase o triplo de torcedores do que os paulistas ( $13 \%$ contra 5\%). Mais popular e de torcida descentralizada. São Paulo não perde seus ares de província.
} 
à festividade carioca, esta nasceu nas ruas, espontânea, desregrada e democrática. Tanto o futebol, quanto o carnaval são símbolos de um país em urbanização, industrialização em que ocorriam constantes mudanças sociais e culturais desde o fim do século XIX.

O governo Campos Salles teve duas características essenciais: a política dos Estados e o funding loan.

Política dos Governadores ou dos Estados, como denominou o então governante, nada mais era do que um acordo entre o governo central e as diversas oligarquias estaduais de submissão aos interesses recíprocos. Os diversos partidos republicanos ( havia praticamente um em cada estado), por meio de uma liderança oligárquica, recebiam o apoio dos eleitores controlados pelo cabresto dos coronéis em seus currais eleitorais. O candidato apoiado pelo coronel era o indicado pelo líder político do partido em seu estado. Este líder oligarca, por sua vez, dava sustentação aos interesses do governo central no Rio de Janeiro. A vitória nas eleições, em tempos sem justiça eleitoral, só valia com a diplomação do eleito, que ocorria após a Comissão de Verificação ratificar o resultado. Criada por Campos Salles, a Comissão de Verificação consertava os resultados indesejados nos pleitos. Edgar Carone explica-nos a nova política:

(...)Campos Sales entra em combinações com todos os governadores e lideranças políticas e modifica o mecanismo de Verificação de Poderes da Câmara dos Deputados. Essa tática resulta num controle geral dos Estados, daí ter sido denominada de política dos governadores, ou, como o autor gosta de chamá-la, política dos Estados.

Verificação dos Poderes é um órgão constituído por uma comissão de elementos da Câmara dos deputados ou Assembleia estaduais para receber as atas eleitorais, isto é, os livros de votação dos eleitores, verificar se houve ou não fraude, proclamar os deputados vencedores e diplomá-los... ${ }^{44}$

As palavras de Campos Salles são precisas sobre a Política dos Governadores:

Neste regime, disse eu na minha última mensagem, a verdadeira força política, (...) deslocou-se para os Estados. A Política dos Estados, isto

${ }^{44}$ CARONE, Edgar. Instituições. Página. 307 
é a política que fortifica os vínculos de harmonia entre os Estados e a União é, pois, na sua essência, a política nacional. É lá, na soma dessas unidades autônomas, que se encontra a verdadeira soberania da opinião. O que pensam os Estados pensa a União! ${ }^{45}$

Por meio desse acordo de cavalheiros entre a presidência da República, as elites regionais e o poder local dos coronéis é que foi possível a imposição de um plano econômico com medidas tão rígidas e recessivas como o funding loan. A política dos Estados foi uma brilhante estratégia política num país de dimensões continentais e interesses conflitantes. Não é à toa que um século depois o presidente Fernando Henrique se autoproclamava o "novo Campos Salles". Como sempre, a tudo isso, o povo assistia bestializado e quando resolvia participar da história era sumariamente defenestrado. A conjunção de interesses entre a política e o rolamento da dívida existe desde:

Quando ( Campos Sales) toma posse ( 15-11-1898), o governo anterior já assinara o Funding Loan, endossado por ele; o Partido Republicano Federal está cindido e as oligarquias estaduais lutam pelo poder. O lema é ' não tomar a iniciativa de uma só despesa e votar todas as economias possíveis'; não permitir que os partidos sejam exclusivos e egoístas, pois devem subordinar seus interesses à Nação. E o principal, acabar com as grandes reuniões políticas, onde a maioria delibera, pois 'esta é uma função que pertence à poucos e não à coletividade. Nem sempre nas deliberações coletivas prevalece o alvitre mais justo e mais conforme os grandes interesses da situação. Ao contrário, as mais das vezes [nelas]...predomina o conselho apaixonado dos mais exaltados, que nem sempre se inspiram no sentido de justiça ou nas verdadeiras e reais conveniências da causa pública. Isso é tanto mais perigoso, quanto é certo que, no momento atual, dada a ausência de partidos regulares, nos achamos em pleno estado de anarquia política'. ${ }^{46}$

\footnotetext{
${ }^{45}$ SILVA, Hélio. Campos Salles.

${ }^{46}$ CARONE, Edgar. Instituições. Página. 308
} 
$\mathrm{Na}$ esfera estadual, Campos Salles e seus sucessores oligárquicos garantiram o predomínio político por meio da Política dos Estados. Regionalmente, o controle político foi garantido pelo Coronelismo. Victor Nunes Leal ${ }^{47}$ defende que:

(...) os dois aspectos - o prestígio próprio dos coronéis e o prestígio de empréstimo que o poder público lhes outorga - são mutuamente dependentes e funcionam ao mesmo tempo como determinantes e determinados. Sem a liderança do coronel' - firmada na estrutura agrária do país -, o governo não se sentiria obrigado a um tratamento de reciprocidade e, sem essa reciprocidade, a liderança do 'coronel' ficaria sensivelmente diminuída.

Dessa forma, o mandonismo local seria um poder privado enfraquecido provindo de uma estrutura socioeconômica arcaica, em contradição com estruturas públicas representativas e federalizadas, porém em gestação. A aliança entre o arcaico e o novo, ambos enfraquecidos, alimentava interesses mútuos. O coronelismo é uma estratégia de poder privado. Ocupa espaços deixados pelo poder central, controla a economia e a questão social. Define o pertencimento e a exclusão. Seu nome advém de uma:

Patente da guarda nacional obtida ou comprada por fazendeiros e industriais locais, espalhando-se a instituição por todos os municípios. $\mathrm{O}$ uniforme e as insígneas tornam-se símbolos representativos de privilégios legais. O significado hierárquico define o mandonismo político, reflexo natural das estruturas existentes. A fragilidade dos poderes centrais - federais e estaduais - permite a formação de lideranças dos mais aptos e poderosos. É verdade que elas representam a continuidade de um 'exorbitante poder privado', num regime em que as vontades e obrigações são leis; contudo para chegar a estas condições não existe só o 'simples ato de vontade'(...)

Socialmente, o coronel exerce uma série de funções que o fazem temido e obedecido, o que ele deve aos seus dotes pessoais, e não ideológicos. É o chefe do clã, título que engloba ' não só a família' que lhe segue e obedece as pegadas mais próximas, mas o cabroal que vive em função de seu prestígio, da sua força, do seu dinheiro'. Aos agregados, ele dispensa favores: dá-lhes terras, tira-os da cadeia e

${ }^{47}$ LEAL, Victor Nunes. Editora Alfa-ômega. São Paulo. 1976. Pág.43 
ajuda-os quando doentes; em compensação exige fidelidade, serviços, permanência infinita em suas terras, participação nos grupos armados. Aos familiares e amigos ele distribui empregos públicos, empresta dinheiro, obtém créditos; protege-os das autoridades policiais e jurídicas, ajuda-os a fugir dos compromissos fiscais do Estado. É o juiz, pois obrigatoriamente é ouvido a respeito de questões de terras e até de casos de fuga de moças solteiras. É comerciante e agricultor, porque produz e serve de intermediário entre o produtor e o mercado, jogando com os maiores recursos financeiros e representando a potência econômica... ${ }^{48}$

O imaginário em relação aos coronéis difunde a imagem de um latifundiário violento e de pouca cultura. Um exercício do poder por meio do mandonismo local e característico do atraso econômico e moral. Nada mais errôneo. Mais uma vez é Carone que nos dá notícia sobre a família Murtinho, do ministro e político Joaquim. Nas disputas entre os Ponce e Totó Pais, ainda na virada do século (ou seja, quando Joaquim Murtinho era o responsável pelo ministério da Fazenda no governo Campos Salles), partidários do general Ponce fogem de suas residências:

Políticos e pessoas de destaque fogem de Cuiabá para a Usina Conceição, propriedade do vice-presidente João Pais de Barros e irmão de Totó, certos de que lá nada os atingiria. Porém, Totó Pais organiza uma coluna especial e cerca a usina, no dia 3 de novembro de 1901. Homens e técnicos especializados fazem parte da coluna; de nada adianta mostrar que os foragidos e trabalhadores da usina estavam desarmados. O proprietário, seus familiares e trabalhadores são presos. A lista de nomes é trazida de Cuiabá pelo próprio chefe de polícia e os prisioneiros são divididos em 3 grupos: do primeiro, com mais de 100 pessoas, 60 e poucos são obrigados a assentar praça na polícia e o resto vai para a Usina Itaici, de propriedade de Totó Pais, onde trabalharão quase como escravos; outro fica prisioneiro na usina; no terceiro, 16 pessoas são levadas por terra e 'amarrados de braços para trás pela escolta que os conduzia, seguindo assim a pé até o lugar denominado Potreiro, onde, junto a uma baía, conhecida pelo nome de Garcez, foram um a um fuzilados, saqueados e os cadáveres, com os

\footnotetext{
${ }^{48}$ CARONE, Edgar. Instituições. Página. 252-253
} 
ventres partidos em cruz, para não boiarem, lançados n'água à ferocidade das piranhas, ficando ali postada uma guarda até que desaparecessem. $^{49}$

O campineiro Campos Salles teve seu governo marcado pelo acordo internacional com bancos estrangeiros. Joaquim Murtinho, seu ministro da Fazenda, colocou em prática as duras medidas econômicas, financeiras e fiscais. $\mathrm{O}$ terceiro capítulo desta Tese irá aprofundar o funding loan. Mas vejamos alguns aspectos.

As negociações para o funding loan iniciam-se em junho de 1898, fim do mandato de Prudente de Moraes. Campos Salles, eleito, acompanhou as negociações com os bancos estrangeiros. O London and River Plate Bank, London and Brazilian Bank e o Brazilianische Bank fur Deutschland, que tiveram papel essencial junto aos representantes brasileiros — os presidentes em exercício e o eleito, além do ministro Bernardino de Campos - para a elaboração de um novo contrato que:

Era uma solução ou, mais exatamente, o meio de permitir ao Brasil modificar tranquilamente seu sistema tributário, de modo a restabelecer o equilíbrio real de suas finanças e de reabilitar-se, atacando o mal pela raiz: os abusos das emissões, o acréscimo inconsiderado das despesas, a preponderância dos direitos aduaneiros na receita global da União. ${ }^{50}$

Os pontos principais do Acordo assinado em 1898 e conhecido como funding loan são:

I. A substituição das dívidas anteriores por apenas uma dívida nova;

II. Garantia mínima de juros de 5\% pagos em títulos-ouro em funding bonds emitidos sobre as dívidas das ferrovias;

III. Concessões de novas ferrovias para investidores, com garantia mínima de juros;

IV. Emissão de títulos no valor de máximo de 10 milhões de libras (não passaram de 8,6 milhões no total);

V. Hipotecou-se a Alfândega do Rio e de outras cidades como garantia dos empréstimos;

\footnotetext{
${ }^{49}$ CARONE, Edgar. Instituições. Página. 183

${ }^{50}$ CALÓGERAS, Pandiá. A política monetária no Brasil. Pág. 523
} 
VI. Simultaneamente a emissão dos títulos, o governo teria de depositar valor equivalente em papel-moeda, parte dele seria retirada de circulação e destruída.

Percival Farquhar, o defunto-autor desta Tese, encontrou no acordo internacional uma possibilidade grande de investimentos. O Brasil tornava-se uma economia saudável do ponto-de-vista do mercado financeiro internacional e, claro, com a garantia mínima de lucros em construções e arrendamentos de ferrovias. O governo Campos Salles:

(...) começa seu mandato sob o peso de compromissos e a garantia ao capitalismo internacional. Diferentemente de seus antecessores, ele tem a segurança de um acordo - o Funding Loan que lhe dá certas regalias, mas também representa o direito e a interferência direta do capitalismo estrangeiro no controle das finanças brasileiras. Ao ser empossado, Campos Sales deve resgatar 115:997:700\$000 de papelmoeda devidos ao Funding; os títulos de dívida pública estão cotados nas bolsas estrangeiras pela metade do seu valor; além disso ele tem a obrigação de pagar o resto do empréstimo de 2.000 .000 de libras feito por Prudente em 1897; letras idênticas, emitidas internamente como antecipação de receita. ${ }^{51}$

O mais impopular presidente da República Velha conseguiu ter sucesso nas medidas econômico-financeiras adotadas. Cerca de $25 \%$ do papel-moeda em circulação desapareceu. A arrecadação cresceu constantemente. Investidores estrangeiros aportaram num país "confiável”. O Metalismo dera certo ( descontando-se os interesses da maioria da população). O acordo foi possível porque:

As medidas tomadas por Campos Sales tornam-se possíveis devido a sua atuação política e ao apoio do Congresso e dos governadores. É assim que deixa de existir oposição aos projetos econômicofinanceiros apresentados, facilitando o plano de governo. Joaquim Murtinho, o novo Ministro das Finanças, segue exatamente as suas diretrizes. Inicialmente aceleram-se certas medidas tomadas pelo governo anterior, como a estrita economia de gastos, principalmente militares, e a maior incidência do imposto de consumo. Este já provocara grita quando Bernardino de Campos impôs o pagamento do

\footnotetext{
${ }^{51}$ CARONE, Edgar. Instituições. Página. 252-253
} 
selo como taxa de certos produtos. Agora, o imposto funciona, não como complemento, mas como fator fundamental do aumento da receita da União. As medidas sucedem-se ininterruptamente: de fevereiro a junho de 1899, decretam-se leis de incidência do imposto de consumo para bebidas, fumo, perfumarias, velas, calçados, especialidades farmacêuticas, perfume e vinagre, conservas de carne e cartas de jogar. Como se vê, são os produtos populares os mais atingidos, o que vai provocar mal-estar e grandes dificuldades às camadas populares.

No mesmo ano, em 20 de julho, decreta-se a criação do fundo especial aplicável ao resgate e outro para a garantia do papel em circulação. Os recursos para as primeiras destas medidas proviriam da renda, em papel, do arrendamento das estradas de ferro da União; do produto da dívida ativa da União; de rendas eventuais do Tesouro; e dos saldos do orçamento. Para o segundo caso, as garantias viriam da cota de 5\% ouro, resultante dos produtos de importação para consumo e do saldo das taxas arrecadas em ouro(...) $)^{52}$

Edgar Carone demonstra que havia uma autonomia financeira persistente nas emissões de moeda até fins da República Velha. Mesmo com as tentativas centralizadoras de Rui Barbosa, ou mesmo com as medidas restritivas de Joaquim Murtinho, a situação de verdadeiros estados autônomos permanecia.

(...) crescente autonomia local: sabe-se da existência destes verdadeiros estados, mas a sua ligação com aqueles dois poderes e os acordos de proteção mútua fazem com que certos atos extralegais subsistam tranquilamente durante a Primeira República. A cunhagem de dinheiro particular é um exemplo: e, 1924, a Mate laranjeira, que nessa época pertence aos Murtinho ${ }^{53}$ e a argentinos, fabrica suas 'notas novinhas, bilhetes bem simpáticos e coloridos, com valor nitidamente bem expresso e a respectiva promessa de resgate...puro estilo Banco do Brasil'. Em Lavras Diamantinas, Bahia, dá-se o mesmo em 1927: à falta de moedas divisionárias, Horácio de Matos lança mão de um recurso original: faz emissões impressas, de vales coloridos dos mais diversos valores que passam a correr pela chapada

\footnotetext{
${ }^{52}$ CARONE, Edgar. Instituições. Página. 232

${ }^{53}$ A História nos proporciona exemplos interessantes, afinal o coronel mato-grossense Joaquim Murtinho foi alçado á condição de sábio administrador. O ministro dos cortes de moedas, metalista até a raiz, emitia seus papéis coloridos na imensa propriedade familiar.
} 
inteira e são trocados nas feiras livres como um novo papel-moeda, mais valioso do que o dinheiro do governo. ${ }^{54}$

Mas desfaçatez mesmo cometiam os Jafet em São Paulo. Carone (2000) ao fazer uma curta biografia dos principais industriais de São Paulo nos conta da família Jafet. Um dos irmãos possuía uma imensa tecelagem próxima ao Ipiranga. Pagava seus operários não em dinheiro, mas em vales que permitiam comprar em armazéns e lojas de mercadorias, todas pertencentes aos seus outros irmãos. Era a mais valia da mais valia. O empresário brasileiro era mais confiável do que o polvo imperialista.

Impopular nacionalmente, Campos Salles e suas medidas saneadoras fiscais e econômicas, sai do governo debaixo de vaias. O trajeto pela capital federal e subúrbios foi traumático para ele. Entretanto, foi recebido de braços abertos por seus aliados paulistas. O presidente da província, seu amigo, o aguardava. Cumprira sua missão com a elite que representava:

Depois da posse de Rodrigues Alves, no dia 15 de novembro de 1902, Campos Sales se retira para São Paulo; perto da estação e durante o trajeto de trem pelos subúrbios, milhares e milhares de pessoas apitam e vaiam o ex-presidente que se retira. Ao chegar à capital paulista, no entanto, o Partido Republicano paulista o recebe com festas; Bernardino de Campos e 25.000 pessoas the rendem homenagem. ${ }^{55}$

\subsubsection{Rodrigues Alves (1902-1906)}

Rodrigues Alves ficou conhecido como o "conselheiro". Político tradicional desde o Império, por três vezes governou a província de São Paulo ( a primeira delas, pelo partido Conservador, ainda no Império). Eleito presidente em março de 1902, sem sustos, será comandante do primeiro quatriênio genuinamente “café-com-leite". Posteriormente, em 1918, tornou-se o único reeleito da República Velha. Ironia do destino, o presidente que ficou marcado pelo saneamento e higienização do Rio, faleceu de gripe espanhola antes de tomar posse. O jornal "O Estado de S.Paulo" o recebeu com frieza e críticas suaves, sem deixar de aludir ao antecessor de forma crítica:

O governo da Republica passa hoje das mãos do Dr. Campos Salles para a do Dr. Rodrigues Alves. O primeiro sáe do poder

\footnotetext{
${ }^{54}$ CARONE, Edgar. Instituições. Página. 254

${ }^{55}$ CARONE, Edgar. A República Velha. Política. Pág. 196
} 
impopularíssimo; o segundo vae ao poder cercado de geral, quase absoluta indiferença. Não ha meio de se ocultar este facto, que é da maior evidencia: inuteis todos os esplendores e toda a pompa dos bailes e banquetes, que o subsidio dos senadores e deputados governistas paga quase à força, e para os quais so concorrem espontaneamente os lucros certos ou provaveis dos homens de negocios que enriqueceram na situação que finda ou que pretendem enriquecer na que começa. Resta saber se é justa a enorme impopularidade do Dr. Campos Salles, e se o Dr. Rodrigues Alves merecia ou não que o povo o acolhesse de outra maneira. ${ }^{56}$

A grande obra do primeiro governo republicano iniciado no século $\mathrm{XX}$ foi a reforma sanitária e urbana do Rio de Janeiro ( análise no capítulo 4). Nesse período apareceram diversas revistas na capital. Literárias como a "Kosmos", ou satíricas como “O Malho". Esta última não perdoava a violência das medidas sanitárias. Na edição 79 de 1904, Oswaldo Cruz aparecia fantasiado de nobre francês, com uma imensa vacina à mão esquerda e defronte a um escudo heráldico com mosquitos e ratos. O título da revista era mordaz: “ O Luís XIV da Seringação”. Abaixo do ministro da Saúde estava a frase “ Le tas, c'est moi”. Não o estado, mas o trabalho da vacinação compulsória e autoritária era ele, o nosso rei absoluto.

Joaquim Murtinho, homeopata e espírita, aplicou o remédio severo e ortodoxo sobre a economia no governo Campos Salles. O acordo do funding loan impôs uma redução considerável no dinheiro disponível. Despesas controladas e fim das emissões, adicionadas ao pagamento de juros à banca internacional produziram uma retração econômica no país. Rodrigues Alves e seu ministro da Fazenda, José Leopoldo de Bulhões, contaram com um estado saneado financeiramente, seja pelo alongamento da dívida externa ou por meio da redução do papel moeda em circulação. O capital era abundante na administração federal, pois se de um lado a carga tributária cresceu em valores e em produtos taxados - o presidente Campos Salles em sua sanha arrecadatória recebeu a alcunha de Campos 'Selos', devido aos novos impostos estabelecidos sobre o consumo - , do outro, o lucro da borracha era crescente.

Faltava solucionar a questão do café. A oscilação dos preços internacionais e os elevados custos de produção endividavam o setor. O quadro era

\footnotetext{
${ }^{56}$ Jornal O Estado de São Paulo, sábado, 15 de novembro de 1902. Ano XXVIII. Capa. Disponível em: $\langle$ http://www.estadao.com.br/infograficos/2011/01/OESP_posse ralves.pdf $\rangle$. Acessado em 03 de maio de 2015
} 
piorado pela crise de superprodução. Os cafeicultores defendem uma política intervencionista no produto, desagradando Rodrigues Alves. Controle da produção e dos preços, novos empréstimos internacionais e o estabelecimento de um controle sobre o câmbio, impedindo que o mesmo interferisse nos lucros do café. A política econômica seguiria os interesses exclusivos de um setor da economia e a lucratividade da oligarquia paulista e mineira.

As reuniões do Convênio de Taubaté tiveram início ao final do mandato de Rodrigues Alves e foram sancionadas por Afonso Penna. Nele, foi estabelecida uma Caixa de Conversão, para manter os preços da moeda estrangeira valorizados. O Convênio também adotou uma política de Valorização do Café. Celso Furtado a resume em quatro pontos, e defende que a valorização acabou permitindo um predomínio dos cafeicultores paulistas sobre a economia sem grandes rupturas até $1930{ }^{57}$ :

I. Objetivando restabelecer o equilíbrio entre oferta e procura do café o governo interviria no mercado comprando os excedentes;

II. O financiamento viria de instituições e empréstimos estrangeiros (elencados por Caio Prado Jr abaixo);

III. Os serviços dessa dívida seriam cobertos por um novo imposto em ouro cobrado das sacas de café exportadas;

IV. Os governos dos estados produtores deveriam desencorajar os produtores a expansão da produção.

Caio Prado $\mathrm{Jr}^{58}$ explica o Convênio de Taubaté de 1906. O historiador demonstra que entre 1890 e 1900 os cafezais duplicaram sua área plantada, apesar dos esforços em limitação por parte das autoridades. A dobra da quantidade de pés de café não veio acompanhada da melhoria qualitativa do produto, afinal boa parte dos grãos continuava de baixo valor ou até rejeitados pelo mercado internacional. Mesmo as oscilações nas cotações da libra esterlina no mercado interno foram insuficientes para frear a expansão das lavouras.

O café era responsável por mais de dois terços da renda nacional, mas suas condições de produção continuavam dispendiosas. Entre o plantio e o início da colheita dos grãos decorriam 5 anos. A safra durava apenas 4 meses. Os cafeicultores

\footnotetext{
${ }^{57}$ FURTADO, Celso. Formação econômica do Brasil. Pág. 179. Alterado por este autor.

${ }^{58}$ PRADO JR, Caio. História Econômica do Brasil. São Paulo. Brasiliense. 1993
} 
viviam em crise econômica, mesmo com o baixo custo e a abundância de trabalhadores livres fornecidos, principalmente, pelos imigrantes.

Encontrou-se a solução na intervenção estatal. O governo central compraria os excedentes da produção, o valor de conversão das libras esterlinas recebidas pelos exportadores seria garantido por um câmbio controlado e com desvalorizações pequenas, mas constantes e, por último, seria concedido um imenso empréstimo estrangeiro ( os Rothschild resistiram inicialmente) aos produtores. Note-se que a maior parte dos fundos abasteceriam os cafeicultores paulistas. A República Velha se endividava mais uma vez para salvar a província bandeirante. Segundo Caio Prado Jr, os recursos:

[Serão] a princípio, de uma grande firma exportadora alemã Theodor Wille \& Cia. Era chegada a vez do imperialismo alemão que até esta data não participara senão modestamente das transações brasileiras. Atrás de Theodor Wille alinham-se os principais grupos financeiros daquele país: o Disconto Gesellschaft e o Dresdner Bank. Com eles se ligarão banqueiros ingleses e franceses que formavam a oposição, em seus países aos grupos que tinham em mãos os interesses brasileiros. São eles J.Henry Shröeder \& Co., de Londres e Societé Générale, de Paris. A esta coligação virá juntar-se também o National Bank of New York. Ele fornecerá a São Paulo os recursos necessários para levar adiante o plano de valorização, abrindo créditos na importância de 4 milhões de libras. ${ }^{59}$

Nada mais lógico, segundo o historiador, do que entregar a presidência da República ao mineiro, então vice-presidente Afonso Penna, pois o mesmo era um entusiasta defensor da política de Valorização do Café. A aliança Minas-São Paulo prosseguia.

A política do "café-com-leite", representada pela alternância na administração presidencial entre os dois estados mais ricos e populosos do Brasil, São Paulo e Minas Gerais, com o apoio político do Rio e o beneplácito gaúcho de Pinheiro Machado, fortaleceu o governo oligárquico introduzido pela "Política dos Estados" de Campos Salles.

${ }^{59}$ PRADO JR, Caio. História Econômica do Brasil. 1993. Pág. 231 
O paulista Rodrigues Alves era acompanhado pelo mineiro Afonso Penna, seu vice, no quadriênio 1902-1906. Para a História começara a oligarquia do 'café-com-leite'. No quadriênio seguinte, a vez do exercício da presidência seria de um mineiro, dando prosseguimento ao acordo entre as elites oligárquicas.

\subsubsection{Afonso Penna ( 1906-1909)}

Eleito, Afonso Penna inovou. Ao contrário de seus antecessores, deixou de banhar-se em ares europeus e decidiu percorrer o país de norte a sul, por meio da malha ferroviária. Entretanto, devido aos traçados sinuosos, a falta de interligação entre as ferrovias ou, na maioria das vezes, pela exiguidade de caminhos de ferro no país, o presidente eleito conseguiu percorrer pouco mais de $30 \%$ do trajeto de $16 \mathrm{mil} \mathrm{km}$ em trens. O objetivo seria conhecer de perto a realidade do país que iria governar. Seu mandato durou pouco mais de dois anos e teve uma marca: a expansão da malha ferroviária. Duas delas envolvem diretamente o objeto desta tese: as Estradas de Ferro Madeira-Mamoré e a São Paulo-Rio Grande, ambas entregues ao empresário Percival Farquhar.

Fator fundamental na expansão ferroviária que permitiu a expansão dos negócios do empresário norte-americano foi a antiga lei de ferrovias. O decreto $\mathrm{n}^{\mathrm{o}} 641$, de 26 de Junho de 1852, ainda sob o regime Imperial, autorizava o Governo a concessão das ferrovias para uma ou mais companhias. As concessões poderiam ser cedidas por 90 anos. No $\S 1^{\circ}$, artigo $1^{\circ}$, dizia o decreto:

$\S 1^{\circ}$ A Companhia empresaria terá o direito de desapropriar, na fórma da Lei, o terreno de dominio particular que for necessario para o leito do caminho de ferro, estações, armazens e mais obras adjacentes; e pelo Governo lhe serão gratuitamente para o mesmo fim concedidos os terrenos devolutos, e nacionaes, e bem assim os comprehendidos nas sesmarias e posses, salvas as indemnisações que forem de direito. $^{60}$

Boa parte da riqueza de Farquhar veio da exploração dessa área adjacente ao leito. E o conflito do Contestado, nossa maior guerra civil do século XX, também foi decorrência dessa destinação legal. O governo concedia também a exploração das

\footnotetext{
${ }^{60}$ BRASIL. Distrito Federal. Decreto no 641, de 26 de Junho de 1852. Câmara dos Deputados. Coleção de Leis do Império do Brasil - 1855, Página 5 Vol. 1 pt. I
} 
madeiras ( por isso as serrarias de Farquhar) e a importação de equipamentos sem impostos. Curiosamente, proibia a exploração de mão-de-obra escrava. O parágrafo sexto trazia a grande fonte de lucros:

$\S 6^{\circ} \mathrm{O}$ Governo garantirá á Companhia o juro até cinco por cento do capital empregado na construcção do caminho de ferro, ficando ao mesmo Governo faculdade de contractar o modo e tempo do pagamento d'este juro. ${ }^{61}$

Doente, Afonso Penna acabou falecendo dois anos e meio após assumir. Para a imprensa paulista e a ferina língua de Rui Barbosa, o presidente "tico-tico" fora vítima de um "traumatismo moral". O então ministro da Guerra, Hermes da Fonseca, entregara o cargo descontente com o apoio de Afonso Penna ao jovem David Campista, seu ministro da Fazenda, à presidência. 'Atirara a espada sobre a mesa do presidente, provocando-lhe um traumatismo moral que o levara à morte', dizia Rui Barbosa. O vice assumiria no mesmo dia, 14 de junho de 1909, apenas para controlar o rumo das eleições do ano seguinte entre Hermes da Fonseca e Rui Barbosa.

\subsubsection{Nilo Peçanha (1909-1910)}

Nilo Peçanha era natural de Campos, estado do Rio de Janeiro. Com a morte do presidente Afonso Penna, em junho de 1909, por ser ele o Vice Presidente, assume o cargo. Substitui o ministro da Fazenda David Campista por José Leopoldo de Bulhões ( que exerceu o mesmo cargo no governo Rodrigues Alves).

$\mathrm{Na}$ verdade houve uma alteração completa na correlação de forças. Campista era o candidato à presidência escolhido por Afonso Penna. Foi um dos fatores do seu enfraquecimento político e da acirrada disputa que viria com a campanha civilista. O objetivo de Peçanha era por fim ao "Jardim de Infância". Afonso Penna tentara renovar a administração brasileira, além de Campista, vários jovens ( alguns de menos de 30 anos) ocuparam cargos de proeminência em seu governo. Daí a alcunha de “Jardim de Infância".

A velha ordem republicana, acostumada ao fraque e cartola, aos bigodes aparados milimetricamente e às bengalas importadas, distintivas de um — inconsciente - monarquismo, rejeitaram a novidade. Nilo Peçanha, como Manuel Vitorino nos 4

\footnotetext{
${ }^{61}$ BRASIL. Distrito Federal. Decreto n ${ }^{\circ}$ 641, de 26 de Junho de 1852. Câmara dos Deputados. Coleção de Leis do Império do Brasil - 1855, Página 5 Vol. 1 pt. I
} 
meses em que substituiu Prudente de Moraes entre 1896 e 1897, mudou toda a articulação política e alterou quase todo o ministério.

A trajetória pessoal de Nilo Peçanha, político que fez carreira durante o Império e permaneceu influente na República Velha, lembra a de Machado de Assis. À medida que ganhava importância política, sua tez era branqueada pelas elites e retocada pelos quadros e fotos oficiais. Teria sido nosso primeiro presidente negro, segundo o historiador Abdias do Nascimento. Ao "mestiço do morro do Coco", frequentemente, proferiam-se anedotas e piadas de cunho racista. Gilberto Freyre ao defender o 'foot ball mulato" brasileiro, uma miscelânea de malemolência com objetividade, capaz de surpreender os adversários e que nos diferenciava dos mesmos, referiu-se à arte política de Peçanha dessa forma:

O nosso estilo de jogar futebol me parece contrastar com o dos europeus por um conjunto de qualidades de surpresa, de manha, de astúcia, de ligeireza e, ao mesmo tempo, de brilho e de espontaneidade individual em que se exprime o mesmo mulatismo de que Nilo Peçanha foi até hoje a melhor afirmação na arte política. ${ }^{62}$

Governou pouco mais de um ano e sua grande preocupação foi eleger seu sucessor. A cisão na oligarquia do "café-com-leite" o impediu. Afonso Penna com sua insistência no jovem ministro da Fazenda David Campista, mineiro como ele, levou a um impasse entre três candidatos: o Barão do Rio Branco, que logo desistiu; Hermes da Fonseca, sobrinho de Deodoro e o grande responsável pela organização e profissionalização do Exército brasileiro, apoiado por Pinheiro Machado e pelo partido Republicano do Rio Grande do Sul e, por último, Rui Barbosa, o ministro do Encilhamento.

Rui Barbosa decide enfrentar o candidato e "amigo" militar Hermes da Fonseca. Era a Campanha Civilista. Foi a primeira eleição com votação expressiva da oposição, representada por Rui Barbosa. O candidato oficial saiu vitorioso, porém a campanha de Rui Barbosa contou com razoável apoio popular em São Paulo, na Bahia e na Capital Federal. Nas zonas eleitorais de São Paulo e do Rio não se permitiu novos alistamentos e as centenas de eleitores dos setores médios, empolgados pela candidatura civil, sequer puderam votar. No interior, o predomínio político e militar dos coronéis

\footnotetext{
${ }^{62}$ FREYRE, Gilberto. Foot-ball mulato, in Diário de Pernambuco, 17-6-1938. Disponível em: < http://www.ururau.com.br/cidades43051_H\%C3\%A1-90-anos-falecia-o-presidente-campista,-Nilo-Proc\%C3\%B3pioPe\%C3\%A7anha>. Acessado em 30/04/2015
} 
nordestinos e da região central do Brasil, como os Murtinho e Ponce em Mato Grosso, carregava os currais eleitorais com seus votos de cabresto. Votações fraudadas, em que os donos do poder eram protegidos por garruchas e o Comitê de Verificação, instituído por Campos Salles, alterava resultados. Eleições a bico de pena ( com dezenas de votos assinados pela mesma pessoa) e de fósforo ( os mortos que estranhamente apareciam como eleitores). Não bastasse isso, cabe lembrar que a maioria dos brasileiros ${ }^{63}$ não eram considerados cidadãos. Hermes da Fonseca era eleito, apesar do apelo profético de Rui Barbosa em campanha:

Rejeito as doutrinas do arbítrio. Abomino as ditaduras de todo gênero, militares ou científicas, coroadas ou populares. Detesto os estados de sítio, as suspensões de garantias, as razões de Estado, as leis de salvação pública. Odeio as combinações hipócritas do absolutismo, dissimulado sob as formas democráticas e republicanas. Oponho-me aos governos de seita, aos governos de facção, aos governos da ignorância. Bem o sabeis: estas são minhas crenças, os meus ódios são esses. $^{64}$

$\mathrm{Na}$ esfera administrativa, os compromissos com o sistema financeiro internacional mais uma vez são respeitados. Nilo Peçanha pronuncia-se ao Congresso em 1910 dessa forma:

Praticando uma politica de rigorosa restricção das despesas publicas, poude o Governos nos mezes ultimamente decorridos, iniciar as remessas para a Europa de fundos que attingiram a quantia superior a 9.000.000 esterlinos. (...) usando da autorisação em boa hora concedida pelo Congresso Nacional, antecipar o serviço de amortisação de nossa divida externa, suspensa pelo contracto do funding-loan. ${ }^{65}$

Nilo Peçanha instituiu o Sistema de Proteção ao Índio e Localização dos Trabalhadores Nacionais (SPILTN e depois de 1918 somente SPI, um precursor da Funai de 1967). Organizado e dirigido pelo tenente-coronel Cândido Rondon em 1910 o SPI o teve como diretor de direito até 1930 ( na maior parte desse período, o diretor de

\footnotetext{
${ }^{63}$ Nas eleições de 1910, a mais disputada da República Velha, Hermes da Fonseca derrotou Ruy Barbosa por 403.867 contra 222.822, o que correspondia a menos de $3 \%$ dos habitantes do Brasil no período.

${ }^{64}$ SILVA, Hélio. Rodrigues Alves. Editora Três. Rio. 1983. Pág. 122

${ }^{65}$ PEÇANHA, Nilo. Mensagem apresentada ao Congresso Nacional na abertura da segunda sessão da setima legislatura. Rio de Janeiro. 1910. Pág.10.
} 
fato foi o engenheiro José Bezerra de Cavalcanti), quando já ostentava a patente de General. Dando sequência a política indigenista do Império, o SPI procurava "civilizar" os índios e fornecer braços para uma economia em crescimento.

O entendimento predominante, até a metade do século XIX, era de que as terras apossadas pelos índios era domínio originário destes e, dessa forma, o território em que as dezenas de civilizações aborígenes se organizavam não podiam ser alienadas, muito menos desapropriadas, sequer repassadas ao Estado como terras devolutas.

A partir do Decreto 426/ 1845 um "Regulamento acerca das Missões de catechese e civilização dos indios" e logo após com a Lei de Terras (1850) a visão e as práticas começam a mudar. Aos poucos, as políticas do isolacionismo e a interiorização provocadas pelas reduções e aldeamentos jesuítas caíram em desgraça. O objetivo agora era a formação de grandes aldeamentos indígenas, com a devida concentração da população em áreas delimitadas e seguidas por um esforço assimilacionista. A economia brasileira precisava de braços livres e terras; os índios poderiam fornecer os dois.

Guerras, massacres, ocupações forçadas, deslocamentos compulsórios de centenas de povos e culturas. Os mais radicais, como o diretor do Museu Paulista Hermann von Ihering, defendiam em 1907:

Se se quiser poupar os índios por motivos humanitários é preciso que se tomem, primeiro, as providências necessárias para não mais perturbarem o progresso da colonização. Claro que todas as medidas a empregar devem calcar-se sobre este princípio: em primeiro lugar se deve defender os brancos contra a raça vermelha. Qualquer catequese com outro fim não serve. Por que não tentar imediatamente? Se a tentativa não der resultado algum, satisfazerem-se as tendências humanitárias; então, sem mais prestar ouvidos às imprecações enfáticas e ridículas de extravagantes apóstolos humanitários, proceda-se como o ascendente da nossa civilização, visto como não representam elemento de trabalho e de progresso. 66

Os índios foram concentrados em aldeamentos próximos aos grandes centros do país, suas terras originárias transmutaram-se em devolutas, e a orientação positivista e "científica" do SPI encerrou a equação assimilando a "horda de bárbaros" à República.

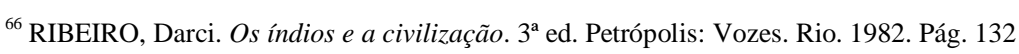




\subsubsection{Hermes da Fonseca (1910-1914)}

O terceiro militar a governar o país, assumiu em plena crise econômica. A produção de café bem acima das necessidades internacionais, a decadência da borracha com a concorrência do sudeste asiático, bem como o vencimento das primeiras parcelas do funding loan, impunham a Hermes da Fonseca uma administração eficiente. Despreparado politicamente, incapaz de conduzir a economia, desrespeitando os princípios democráticos, autoritário e dando prosseguimento ao tratamento da "questão social como caso de polícia”, como diria Washington Luiz tempos depois, o presidente cumpriu a "profecia" civilista de Rui Barbosa. O discurso político parece perfeito. Em 1912 assim se pronunciou Hermes da Fonseca ao Congresso:

A situação financeira do paiz reclama dos poderes públicos especial atenção e a máxima prudencia(...) Não augmentar a despesa de qualquer natureza, nem despender além das previsões orçamentarias, é o regimen que se impõe aos responsáveis pela boa marcha das cousas publicas e pela ordem na gestão financeira. (...) [A] notável expansão da nossa renda não foi sufficiente para pôr ordem na situação financeira, porque a progressão crescente das despesas excedeu o augmento da receita.

(...)

Pela estatística de 1911, apurou-se que a renda dos impostos de consumo nesse anno, importou em 59.870:407\$359 [ quase 10\% a mais que em 1910 e $22 \%$ a mais comparada a 1909. Comentário nosso] (...) existiam na Republica 11.335 estabelecimentos fabris sujeitos aos impostos de consumo, sendo: 2118 fabricas de preparados de fumo; 1.544 de bebidas; 30 de phosphoros; 4.542 de calçados; 11 de velas; 272 de perfumarias; 623 de especialidades farmacêuticas; 319 de vinagre; 291 de conservas; 7 de cartas de jogar; 543 de chapéos; 20 de bengalas; 190 de tecidos e 834 salinas. Além disso foram registradas 2.964 casas commerciaes a retalho, de um ou mais de um producto tributado, e 4.951 mercadores ambulantes. ${ }^{67}$

Infelizmente, o discurso nada possuía de comum com a prática. Percebese nas estatísticas econômicas apresentadas o avanço da produção industrial no país. Assunto a ser tratado com mais profundidade no Capítulo 7.

\footnotetext{
${ }^{67}$ FONSECA, Hermes da. Mensagem apresentada ao Congresso Nacional na abertura da segunda sessão da oitava legislatura. Rio de Janeiro. 1913. Págs. 134-183,184.
} 
Percival Farquhar tem seu auge e ocaso no governo Hermes da Fonseca. Nesse período ele inaugura a Ferrovia Madeira-Mamoré e inicia a exploração da região do Contestado. Capitalizado, ele administrava a construção de obras relacionadas aos serviços coletivos. Entre eles, seu principal investimento eram as ferrovias. No início do século XX fundou a Cuba Railroad e construiu na ilha, recém independente, a ferrovia Santa Clara-Santiago. A seguir investe na Guatemala. Seus investimentos chegam ao Brasil em 1905. Aqui adquiriu a Tramway Light \& Power Company. Começou a controlar o capital das empresas de Luz de São Paulo e Rio de Janeiro. Comprou também os bondes de transporte coletivo nas mesmas cidades.

Por meio de sua holding, a Brazil Railway deu o grande passo na edificação de um gigante empresarial no Brasil. Passou a ter direitos sobre a concessão de novas ferrovias, a construção de portos, tornou-se responsável pela reforma dos existentes e a manutenção dos que estavam em bom estado. Seu principal faturamento viria da administração das estradas de ferro e dos portos e pelo recebimento de juros pagos pelo governo republicano em troca das benfeitorias realizadas ( as privatizações ou seu eufemismo "parceria público-privado" são bem mais antigas do que se pensa).

Farquhar construiu os Portos de Belém (PA) e Rio Grande, no sul do país. Centralizou e quase monopolizou o sistema ferroviário paulista ao adquirir a Paulista, a Sorocabana e a Mogiana. Ergueu também grandes e polêmicas ferrovias, quais sejam, a Madeira-Mamoré na região Norte e a São Paulo-Rio Grande na região sul do Brasil. Conflitos como o do Constestado ou as mortes em série na Madeira-Mamoré não o incomodavam. Derramava rios de sangue como o dono do baleeiro de Moby Dick.

Montou a Amazon River Steam Navigation Co. e comprou dezenas de barcos para escoar a borracha amazônica e ser o único explorador da atividade fluvial na região. A borracha não deu o lucro imaginado.

Em Osasco fundou a Brazil Land, Cattle \& Packing Co. e adquiriu 200 mil cabeças de gado e 3,2 milhões de hectares de terras para fornecer carne para a metrópole nascente armazenadas no Frigorífico Continental ( hoje Frigorífico Wilson).

O conglomerado de Farquhar recebia juros anuais de investimentos que variavam de 6 a 12\%. No total as terras de Percival no Brasil aproximavam-se de 50mil $\mathrm{km}^{2}$, quase a dimensão do estado do Rio de Janeiro.

A partir de 1911, Farquhar começa a fracassar nos negócios, empresas quebram, o dinheiro dos bancos estrangeiros rareia, em 1914 estoura a Primeira Guerra. Ele perde quase tudo. Volta ao Brasil no final dos anos 20 para fundar a Itabira Iron, 
que posteriormente foi estatizada e incorporada à Companhia Vale do Rio Doce. Morre em terras brasileiras em 1953.

Queria ser um misto de Rockfeller e Vanderbilt no mundo tropical. Farquhar, entretanto sofreu represálias dos empresários nacionais e da elite cafeicultora brasileira. Os Metalistas enxergavam-no como um Papelista à serviço dos Estados Unidos (chegaram até a defender que ele preparava uma invasão militar ao Brasil, nos moldes da perpetrada pela política do Big Stick em Cuba).

Farquhar representava o capital de vários empresários e instituições financeiras estrangeiras, poucos deles dos EUA, sua terra natal.

O empresário fazia parte de um mundo em que conviviam barões do café, empresários urbanos, imigrantes, operários, negros excluídos e recém-libertos, agricultores e sem terra. Sobretudo um mundo de desigualdades sociais, econômicas e regionais profundas. $\mathrm{O}$ arcaico convivendo com o novo. $\mathrm{O}$ campo começando a enfrentar a cidade. O nascimento do Capitalismo Industrial no país.

Machado de Assis em "Esaú e Jacó" (1904) interpreta os novos tempos com uma frase: "O dinheiro não traz felicidade - para quem não sabe o que fazer com ele”. O caldeirão de culturas que dará origem ao Brasil atual, repleto de incongruências, desigualdades e sonhos de grandeza. Num mundo que sai da Belle Époque e entra na Grande Guerra. Um mundo destruído e iniciando a divisão Socialismo e Nazismo.

Entre as grandes obras concedidas, estava a Ferrovia São Paulo-Rio Grande. Com pouco mais de 380km de extensão ela foi entregue a Percival Farquhar em 1908. O Syndicato institui a Brazil Raylway Company. Localizada numa região de antigas disputas territoriais entre as províncias do Paraná e Santa Catarina, denominada de Contestado, a estrada de ferro estava encravada e atravessava latitudinalmente uma área de $48 \mathrm{mil} \mathrm{km}^{2}$ ( $60 \%$ dela ficou com os catarinenses na disputa limítrofe).

O empresário norte-americano recebeu também uma faixa de $30 \mathrm{~km}$ a norte e outros tantos ao sul dos trilhos. Terminada a obra ferroviária, ele montou " $\mathrm{O}$ Colosso", um imenso complexo industrial administrado por outra sociedade anônima: a Southern Brazil Lumber and Colonization Co. Extração e exploração madeireira, fábricas de papel, controle sobre a produção de erva-mate, frigoríficos, criação pecuária e a administração de todo o sistema ferroviário controlado por Farquhar no Brasil. A Lumber possuía capitais ingleses e canadenses. Instalado o império, a empresa buscou nas áreas adjacentes os trabalhadores para o projeto. Farquhar foi o nosso Cecil Rhodes. 
A região do Contestado concentrava aproximadamente 40 Cidades Santas, nome dados as comunidades formadas por jagunços sulistas, mulheres, crianças paupérrimos, além de milhares de negros e mestiços que após a construção da ferrovia, abandonados por Farquhar, acabaram por se juntar às comunidades milenaristas do Contestado.

O empresário fraudava documentos de propriedade em cartórios para se apropriar das terras dos seguidores dos "monges" João Maria ( líder messiânico e histórico dos contestados, que iria retornar para um novo tempo) e José Maria, um novo líder, mais agressivo e que acabou morrendo no início dos combates contra o exército central em 1912. Farquhar ameaçava os habitantes das comunidades e usava da força necessária, aliado aos enfraquecidos coronéis da região para ampliar suas posses.

Hermes da Fonseca se desesperou com o discurso monarquista das lideranças do Contestado. José Maria e depois dele, Adeodato, comandavam os sertanejos em saques às comunidades vizinhas, invasões de propriedades e enfrentamentos contra coronéis e interesses do capital estrangeiro, representados pela Lumber.

A matança começou em 1912. A Guerra perdurou por 4 anos. Pelo menos um terço do efetivo do exército brasileiro foi combater na região. Historiadores falam em mais de 20 mil mortos entre os moradores das Cidades Santas. A maior guerra civil de nossa história no século XX. Canudos conheceu o poder dos canhões alemães; Constestado (muito mais pobre e dependente do poder regional que a revolta nordestina) recebeu os primeiros ataques aéreos. A ordem era que Setembrino de Carvalho ( o comandante das tropas) não deixasse uma alma viva, um prédio de pé, uma igreja sequer a badalar os sinos.

Assim como em Canudos 20 anos antes, ou na revolta da Vacina carioca, ou mesmo na rebelião dos marinheiros contra a Chibata em 1910 ( durante o governo de Hermes) e tantos outros conflitos ocorridos na República Velha, a estratégia de destroçar os "inimigos" - a população em luta pelos seus direitos, combatendo as injustiças, tentando derrubar as estruturas caóticas de poder —, trair acordos e não ter nenhuma piedade, nem escrúpulos em cometer atrocidades; prosseguia. Tais herois republicanos repousam em nomes de ruas, praças e avenidas perdidas pelo país, ou então descansam nos panteões da história oficial. Sem julgamento.

Ressaltem-se as tentativas dispendiosas e na maioria das vezes, fracassada, de intervir e substituir as oligarquias dominantes em várias províncias do 
país, a denominada Política das Salvações. Boa parte dos opositores da época considerava que quem governava, em verdade, era o líder histórico do Partido Republicano Conservador, o gaúcho Pinheiro Machado. Grande aliado de Hermes da Fonseca, o poder de Pinheiro Machado perdurou por quase toda a República Velha, como uma eminência parda da presidência, somente cessando com seu assassinato em 1915.

Por último, a situação econômica se agravou durante o quatriênio do futuro Marechal. Além da queda brutal nas vendas da borracha e dos custos crescentes pelas intervenções militares internas, entre elas a da Guerra do Contestado, Hermes da Fonseca sofreu com o início da Grande Guerra que trouxe um impacto imediato nas exportações brasileiras, centradas num produto não essencial como o café. Pouco antes de deixar o mandato negociou com bancos estrangeiros o nosso segundo funding loan. Aprofundaremos os 3 empréstimos no capítulo a seguir. 


\title{
CAPÍTULO 3 - JOAQUIM MURTINHO E OS FUNDING LOANS
}

\author{
“ Minha escolha não é mortal" \\ (Dístico no brasão da família nobiliárquica de Henry \\ Lowndes, um dos principais investidores do \\ Encilhamento)
}

\subsection{Introdução}

No prefácio de "Para a Crítica da Economia Política" Marx afirma que na sociedade burguesa:

(...) a produção social da própria vida, os homens contraem determinadas relações, necessárias e independentes de sua vontade, relações de produção estas que correspondem a uma etapa determinada de desenvolvimento de suas forças materiais. A totalidade dessas relações de produção forma a estrutura econômica da sociedade, a base real sobre a qual se levanta uma superestrutura jurídica e política, e à qual correspondem formas sociais determinadas de consciência. O modo de produção da vida material condiciona o processo em geral de vida social, político e espiritual. Não é a consciência dos homens que determina seu ser, mas. Ao contrário, é o seu ser social que determina sua consciência. ${ }^{68}$

Interessa-nos neste segundo e terceiros capítulos a produção da vida material e a história econômica na República Velha entre os fins do século XIX e o início da Primeira Guerra. Por se tratar da reconstrução das relações sociais, políticas, culturais, jurídicas para delinear a estrutura econômica do país, as especificidades econômicofinanceiras serão aprofundadas nos capítulos seguintes.

Apesar de opostos politicamente e totalmente distintos no entendimento do desenvolvimento econômico e social do Capitalismo, Marx e Joseph Schumpeter coincidem na ideia de que para entendermos o funcionamento da economia, nos é imprescindível o conhecimento das engrenagens da vida material e da história econômica. Em História da Análise Econômica de 1961, Schumpeter diz:

Entre esses campos fundamentais, a história econômica, que resulta nos e inclui e os fatos de hoje em dia, é de longe o mais importante.

\footnotetext{
${ }^{68}$ MARX, Karl. Para a Crítica da Economia Política. Coleção os Economistas. São Paulo. Editora Abril. 1982. Pág.26
} 
Eu gostaria de assinalar desde já que, se tivesse de reiniciar meu trabalho em economia, e se me fosse permitido estudar apenas um dos três à minha escolha, esta recairia sobre a história econômica. E isso por três razões. Em primeiro lugar, porque o objeto do estudo da economia constitui essencialmente um processo singular no tempo histórico. Ninguém pode esperar compreender os fenômenos econômicos de qualquer época, inclusive da presente, se não tiver um conhecimento adequado dos fatos históricos, se não for dotado de suficiente senso histórico, ou daquilo que se pode definir como consciência histórica. Em segundo lugar (porque) o relato histórico não pode ser puramente econômico, mas deve inevitavelmente refletir também fatos institucionais que não são puramente econômicos; consequentemente é ele que proporciona o melhor método para entender como os fatos econômicos e não econômicos estão ligados uns aos outros. Em terceiro lugar (porque), acredito que a maioria dos erros fundamentais cometidos na análise econômica tendem a ser devidos, a uma falta de experiência histórica mais que a qualquer outra carência instrumental de análise dos economistas. Duas consequências não auspiciosas podem ser imediatamente deduzidas da argumentação acima. Em primeiro lugar, já que a história constitui uma fonte importante - embora não a única — dos dados do economista, e já que, o economista, em si, é um produto de seu tempo e de todo o anterior, a análise econômica e seus resultados são certamente afetados pela realidade histórica, a única dúvida é em que grau isso ocorre. Nenhuma resposta à altura pode ser obtida para esta questão através de uma simples reflexão, motivo pelo qual sua obtenção por meio de detalhada pesquisa constituirá uma de nossas principais preocupações(...) Em segundo lugar, temos de encarar o fato, de que com a história econômica fazendo parte da economia, as técnicas do historiador são passageiras do grande ônibus que denominamos análise econômica. O conhecimento derivado é sempre insatisfatório. Devido a isto, mesmo aqueles economistas que não são historiadores econômicos e que meramente lêem os relatos históricos feitos pelos outros, devem entender como surgiram estes relatos, sob pena de não assimilar o seu real resultado. ${ }^{69}$

\footnotetext{
${ }^{69}$ SCHUMPETER, J.A. History of economic analysis. Nova York. Oxford University Press. 1961.
} 
( Apud: SMERECSÁNYI, Tamás. História Econômica, teoria econômica e economia aplicada. Revista de Economia Política, volume 12, número 3 (47), julho/setembro de 1992. Pág. 132)

Importante como fonte para os economistas, a História também se apoia em outras ciências e na diversidade dos pensamentos filosóficos e mitológicos, afinal como afirma Schumpeter, somos todos homens de nosso tempo. A linguagem simbólica dos mitos que tanto subsídio ofereceu a Freud e Jung nos auxilia a esclarecer as repetições e continuidades históricas.

Joseph Campbell foi professor do Sarah Lawrence College ( estado de Nova Iork, EUA) entre os anos 30 e 80. A Instituição privada foi fundada pelo magnata americano William Van Duzer Lawrence em 1926 ( ano em que faleceu a esposa dele, Sarah). Seus objetivos iniciais eram ensinar as “Artes Liberais” às mulheres. Ou seja, praticava um currículo livre com enfoque no ensino das Humanidades, Belas Artes e Literatura. Foi nesse campus que Campbell pode se especializar no estudo de religiões comparadas e mitologia. Influenciou artistas, psicanalistas e formou uma geração de seguidores pelo país. Ele defendia que os Mitos são pistas para as potencialidades espirituais da vida humana, além de terem um caráter pedagógico: ensinam e orientam as pessoas sobre os caminhos a seguir. Uma das questões que os pragmáticos sempre o impunham era: qual a importância de se acreditar em histórias 'falaciosas' de deuses e divindades num período em que a tecnologia levara o homem ao espaço? Campbell afirma que:

O problema da humanidade hoje, portanto é precisamente o oposto daquele que tiveram os homens do período comparativamente estáveis, das grandes mitologias coordenantes, hoje conhecidas como inverdades. Naqueles períodos, todo o sentido residia no grupo das grandes formas anônimas, e não havia nenhum sentido no indivíduo com capacidade de se expressar; hoje não há nenhum sentido no grupo $(\ldots)^{70}$

Os mitos transmutaram-se, infelizmente, em histórias da carochinha. Crenças de sociedades primitivas ou de crianças em formação. De nada nos servem. A razão é imperfeita, mas nos leva a libertação. O coletivo perdeu o sentido; vale o indivíduo e

\footnotetext{
${ }^{70}$ Campbell, Joseph. O herói das mil faces. São Paulo. Editora Cultrix/ Pensamento. 1993. PP 373-374
} 
seu egoísmo - devidamente protegidos pela ciência e tecnologia, pelas máquinas e números:

\begin{abstract}
Em nossos dias, esses mistérios perderam sua força; seus símbolos já não interessam à nossa psique. A noção de uma lei cósmica, a que toda a existência serve e à qual o próprio homem deve curvar-se, passou desde então pelos estágios místicos preliminares representados na antiga astrologia, e hoje é simplesmente aceita, em termos mecânico, como fato consumado. A descida das ciências ocidentais do céu para a terra ( da astronomia do séc. XVIII para à biologia do XIX), bem como sua concentração, nos dias de hoje, por fim, no homem... ${ }^{71}$
\end{abstract}

E as denominadas Artes Liberais, como a História, trouxeram seu conhecimento para a terra, abandonando os mitos. A Economia, por sua vez, escondida em dados racionais, estatísticas, tabelas, gráficos e interpretações dedutivas, esquece que sua teoria essencial é talvez o mais poderoso mito dos últimos 3 séculos: o da "mão invisível do mercado".

As políticas econômicas adotadas pelo Brasil entre os fins do século XIX e a ascensão de Getúlio Vargas nos fazem lembrar um mito do mundo clássico: o de Sísifo e seu eterno retorno.

Sísifo é o mais astuto e o menos escrupuloso dos homens. Filho de Eolo, foi o fundador da cidade de Corinto ( antiga Éfira). Sua lenda tem vários episódios, cada um deles serve para reforçar a astúcia do descendente de Eucalião. Num deles, Sísifo descobre que Autólico roubava-lhe o gado. Mandou marcar o casco dos animais com suas iniciais e, no casamento de Anticleia ( a filha do ladrão), Sísifo o desmascara e ganha como prêmio desposar a noiva antes da cerimônia. $O$ filho dessa união indevida e o heroi Ulisses.

Noutro, ao observar Zeus raptar Egina, filha de Asopo, ele acaba entregando o responsável pelo crime. Em troca, Asopo fez brotar uma fonte d'água na cidade de Corinto. Zeus, tomado pela ira, arremessa-o aos Infernos e fulmina-o com um trabalhocastigo. Sísifo tem de empurrar um imenso rochedo sobre uma vertente íngreme. Mal esta rocha atinge o cume, em virtude do peso excessivo da mesma, ela rola ao ponto inicial.

\footnotetext{
${ }^{71}$ Campbell, Joseph. O herói das mil faces. São Paulo. Editora Cultrix/ Pensamento. 1993. Pág. 377
} 
Em Odisseia, Homero descreve de forma diferente o mito: por meio da astúcia, Sísifo aprisiona Thanatos nas profundezas. Por um bom tempo, os homens deixam de morrer. Zeus interfere e obriga-o a libertar o deus dos mortos. Thanatos libertado faz sua primeira vítima e é o próprio Sísifo. Mas a malandragem o faz escapar da pena capital. Entre em acordo com sua esposa, Mérope, única plêiade ${ }^{72}$ a casar-se com um homem, para que ela não lhe vestisse a mortalha fúnebre. Chegando às profundezas ele engana Hades, que solidário com a falta de respeito da esposa de Sísifo em não lhe prestar as honras devidas o manda de volta ao mundo dos homens, vindo a morrer depois de muitos anos. Cientes da astúcia de Sísifo os deuses impõe o castigo famoso do rochedo levado montanha acima. ${ }^{73}$

Desde os fins do Império a política econômica brasileira é trabalho de Sísifo. Um pensador econômico ( sempre estrangeiro) propõe uma nova forma de se atingir a riqueza das nações, com modelos teóricos que alguns anos depois influenciam nossas políticas econômicas e são aplicados pelos governos brasileiros. Tempos depois, o economista e o político caem em desgraça e um novo pensador com uma tese que é quase exatamente o oposto da primeira passa a ser o grande guru das ciências econômicas. Tudo feito anteriormente é desprezado. Cabeças e capitais são cortados. A pedra rola avassaladora sobre homens e ideais.

A uma interpretação dedutiva da realidade, segue-se uma indutiva. Métodos quantitativos são precedidos por qualitativos. Não há equilíbrio. Sempre é realizada uma tábula rasa do passado. Há um tempo de papel abundante e eras de contenções financeiras. E o que vem depois esfacela o que o precede.

Do fim do Império até a Revolução de 30 ( no caso deste estudo), a principal disputa sísifica é a moeda ( tratado no capítulo 7). Períodos Papelistas são superados por eras Metalistas. Ou se incentivam as atividades internas aumentando as emissões de títulos e moedas e restringindo as importações, ou se restringe o capital circulante, tributando-se o mercado interno para o equilíbrio financeiro do Estado.

O laboratório das experiências econômicas: o Tesouro Nacional. As cobaias: os cidadãos. Excluem-se a camada mais pobre e os ex-escravos, estes mal pertencem ao mundo do capital, muito menos às políticas públicas.

\footnotetext{
${ }^{72}$ São as sete irmãs filhas do gigante Atlas e da deusa Pleione. Foram convertidas nas setes estrelas que formam a constelação Plêiade.

${ }^{73}$ Todas as descrições mitológicas foram extraídas de GRIMAL, Pierre. Dicionário de mitologia grega e romana. $2^{\mathrm{a}}$ Ed. Rio de Janeiro. Editora Bertrand Brasil. 1993
} 
A Proclamação da República era decorrência natural das alterações no quadro econômico, na vida política ( com a ascensão do Exército e a crise do latifúndio sem 'os pés e as mãos dos engenhos e cafezais') e na atmosfera social e cultural. A expansão do crédito, as tentativas de se financiar o desenvolvimento industrial e o estabelecimento dos serviços públicos de água, luz, gás, transportes, etc., abria-se uma gama de possibilidades que atraía o capital financeiro, seja ele nacional ou estrangeiro. A Praça estava fervilhando. O "crack" de 1890 e 1891, denominado de Encilhamento, tem suas raízes nesse contexto, não foi uma decisão isolada de um ministro.

Por trás do Encilhamento temos diversas armadilhas econômicas desconsideradas. Rui Barbosa não foi o responsável pela crise financeira, afinal o processo de transformações pelo qual passava a economia brasileira, iniciara-se na crise do Império, em década de 70 do século XIX, tendo como marcas dessas mudanças ao menos cinco fatores: a preponderância do café e a ascensão da nova elite sulista; a lenta, mas contínua urbanização do Brasil; o aporte de imigrantes; o fim da escravidão e a Proclamação da República. Pretende-se nesta tese fazer uma análise mais detalhada do processo econômico que levou às crises financeiras sucessivas do início da República.

Mas o Encilhamento é uma política consciente a favor da industrialização; como vimos, as emissões e o aparecimento de um fantástico número de novas empresas industriais mostram que os decretos de 10 de maio e 11 de maio de 1890 fortalecem fundamentalmente a indústria: o primeiro cobra, em ouro, $20 \%$ dos impostos de importação; o segundo amplia para $100 \%$ o imposto em ouro. Estas medidas encarecem os produtos importados, tornando-os proibitivos, o que ajuda indiretamente os fabricantes nacionais, principalmente os da indústria têxtil. As elevações das taxas alfandegárias sobre certos produtos de luxo, em outubro, reforça essa tendência, apesar de a medida pretender reanimar as finanças públicas. Elas alegram os industriais e seus representantes que, por isso, vão agradecer a Rui Barbosa. Para reforço do desenvolvimento industrial, Rui preconiza o tributo territorial, medida direta contra as classes agrárias. $^{74}$

${ }^{74}$ CARONE, Edgar. Instituições. Pág. 87 
Evidencia-se a luta entre Papelistas e Metalistas. Batalha entre liberais e protecionistas, disputas do setor industrial nascente contra o setor agrário secular de nossa economia, que prosseguiram por toda a República Velha. Rui Barbosa seria um Papelista, o Encilhamento uma política errônea e sem austeridade. Joaquim Murtinho é o primeiro grande Metalista das finanças.

Mais tarde, Farquhar será acusado do mesmo defeito de Rui: liberal e dilapidador de nossas finanças. Com um acréscimo perigoso: o investidor e industrial norte-americano seria um agente do Imperialismo ianque prestes controlar nossa sociedade democrática e igualitária, na visão da elite política e econômica, seja ela a oligarquia rural ou os novos industriais. Os diversos monopólios de Farquhar, a pretexto de se proteger o patrimônio nacional, foram entregues às mãos dos ilustres Guinle, Mayrinks, e outros tantos empresários brasileiros. Estes, por sua vez, defendiam os interesses da elite agrária, eram em geral Metalistas. Luiz Carlos Delome Prado ${ }^{75}$ assim delimita os dois grupos:

(...) duas tendências que influenciavam a política econômica do Brasil. De um lado os comerciantes e uns poucos empresários com interesses em manufaturas, que operavam no negócio de importação e no comércio doméstico e que tendiam a apoiar uma política econômica mais liberal, assim com liberdade de organização para sociedades anônimas. A maioria dessas pessoas pertenciam a chamada corrente papelista. Eles apoiavam o direito de bancos privados e sustentavam que os estoques de meios de pagamento deveriam ser determinados pela demanda doméstica por transações e não pelo estoque de metais preciosos no sistema bancário. Entretanto, nessa época mesmo a escola papelista entendia que deveria haver alguns graus de correspondência entre o estoque de ouro e os meios de pagamento. Os seus oponentes eram os políticos mais tradicionais, os bacharéis, isto é, aqueles formados em direito, que eram educados com a ideia da cautela e austeridade. Sua ideologia era mais próxima daquela dos proprietários de fazendas e rentistas que temiam a inflação e a instabilidade econômica, mas era também apoiados por alguns intelectuais que pregavam doutrinas liberais e cujas visões refletiam o debate econômico na Europa, particularmente o debate na Inglaterra e na França. Esses, conhecidos como metalistas, defendiam um controle

${ }^{75}$ PRADO, Luiz Carlos Delome. A economia política das reformas econômicas da primeira década da República 
monetário rígido e sustentavam que quando houvesse condições materiais para o crescimento econômico, metais preciosos iriam naturalmente fluir para a economia sustentando o progresso, sem que esse crescimento implicasse em inflação e crise econômica.

A visão desprovida de rigor técnico que menospreza as medidas de Rui Barbosa no governo Deodoro da Fonseca, em verdade reproduz as palavras ácidas de Visconde de Taunay em sua obra $O$ encilhamento. Análises econômicas superficiais, repetindo as teses de um empresário prejudicado pelas medidas Papelistas, Taunay afirma no romance histórico que:

Emprêsas do mais alto prestígio, depois de subirem a preços inacreditáveis, tinham passado semestres e semestres sem publicarem o menor balanço, o mais conciso relatório, sem darem qualquer satisfaçãozinha aos ansiosos acionistas, enquanto os títulos iam como que rolando por uma escada abaixo, deixando em cada degrau algumas parcelas do seu renome e da cotação anterior. Uma lástima! Também, já se iam manifestando sintomas de terror, e de vez em quando se ouviam dêsses estalidos precursores, que denunciam grandes desmoronamentos e irremissíveis catástrofes. ${ }^{76}$

Edgar Carone afirma que mais da metade das empresas instituídas no período do "Encilhamento" permaneciam funcionando na época do Funding Loan. Muitos historiadores divulgam o período de Rui como uma fase de suicídio econômico. Como todo discurso, este serve a alguém, no caso o dos interesses da oligarquia rural, dos importadores, dos comissários do café e das nações imperialistas. As rupturas não seriam permitidas dentro da divisão internacional do trabalho, muito menos na estrutura política e econômica interna que controlava a República Velha. O certo é que o temor de um novo encilhamento, ou da adoção de novas políticas de cunho industrialista, nacional e emissionista, levaram às medidas restritivas que se sucederam. Primeiro com o fim das emissões particulares e centralização do capital financeiro dos bancos:

A situação financeira é grave, e os déficits, permanentes. A saída de Rodrigues Alves em 1896, e sua substituição por Bernardino de Campos não levam à mudança de perspectiva. O sul do país está pacificado, mas a crise mundial, os gastos internos e compromissos

${ }^{76}$ TAUNAY, Visconde de. O encilhamento. $4^{a}$ ed. São Paulo. Editora Melhoramentos. 1935. Págs. 256 e 257 
externos obrigam o governo a emitir e a comprar ouro mais caro para saldar suas obrigações. O reflexo da situação é o câmbio cada vez mais baixo. A única medida encontrada é o decreto de 16 de dezembro de 1896, que extingue a responsabilidade emissora do Banco da República do Brasil e passa esse direito à União: o ato que vai ser o fim dos bancos de emissões particulares. ${ }^{77}$

Posteriormente, com a redução do papel-moeda, os acordos internacionais de renegociação da dívida externa, as taxações sobre o consumo e as medidas restritivas de crédito, todas elas introduzidas pelo Funding Loan, acertado por Bernardino de Campos no final do governo Prudente de Moraes e colocadas em prática por Joaquim Murtinho no governo Campos Salles, o risco de um novo Encilhamento se desfaz. .

\subsection{O Primeiro Funding Loan ( 1898)}

Desde a Independência o Brasil passou por um longo período de endividamento externo com claras dificuldades de pagamentos. A acumulação dos serviços da dívida não paga, novos empréstimos junto às instituições financeiras ( em sua maioria inglesas), reescalonamentos e saldos de balança exíguos para a quitação dos empréstimos, prolongou-se de 1824 a 1931; das indenizações a Portugal até nossa primeira moratória. Logo após a Crise do Encilhamento no início da década de 90 do século XIX, o Brasil adota o sistema de consolidação dos empréstimos pretéritos e a quitação num prazo futuro de média duração. Tais empréstimos denominaram-se funding loans. O primeiro ocorreu em 1898, o segundo em 1914 e o terceiro deles em 1931, no período getulista.

As garantias concedidas pelo Brasil às instituições financeiras internacionais pelo funding loan passavam pelas tradicionais políticas de austeridade fiscal e monetária. Sinônimos de deflação, desemprego e redução brutal do capital circulante. Tudo isso temperado com os cortes assimétricos dos gastos públicos. Sísifo rola a pedra morro acima. Por alguns anos as contas do governo se equilibravam, em decorrência da suspensão dos serviços das dívidas a vencer e pela renegociação que, em geral, permitiam condições melhores de pagamentos. Entretanto, o fator primordial para o alívio estatal era o adiamento do pagamento das parcelas por alguns anos ( o funding loan de 1898 começaria a ser pago apenas em 1910). Para Marcelo de Paiva Abreu:

\footnotetext{
${ }^{77}$ CARONE, Edgar. Instituições. Página. 113
} 
O Brasil foi o melhor pagador dentre todos os países latino-americanos: foi a única economia latino-americana a não suspender o serviço de sua dívida externa desde o lançamento do primeiro empréstimo externo, em 1824, até o começo da vigência do funding loan, em 1898. A partir do fim da década de 1890, entretanto, seguiram-se, com regularidade, crises de balanço de pagamentos e negociações de funding loans. Esses sucessivos empréstimos de consolidação, em 1898, 1914 e 1931, permitiram o alívio imediato do serviço da dívida externa, a solução de crises de liquidez e a retoma -da do endividamento externo no médio prazo nos dois primeiros episódios. O funding loan de 1931 foi, entretanto, o primeiro passo de uma longa sequência de negociações que culminaram no acordo permanente da dívida externa de 1943...78

\subsubsection{Crise do Banco Baring}

Um mal pagador, na ótica dos mercados dos fins do século XIX, foi nossa vizinha Argentina. Nos anos 1880 houve um crescimento vertiginoso dos gastos públicos naquele país, com obras de infra-estrutura como portos, ferrovias, eletrificação, além dos investimentos realizados em melhorias na produtividade rural. Tais investimentos eram sustentados por empréstimos externos, em especial do Banco Baring. Para o pagamento desses empréstimos, o país contava com saldos comerciais elevados em função das exportações de trigo e carne.

Internamente o país vizinho vivia uma febre de consumo garantida por políticas emissionistas do meio circulante. Os déficits em contas públicas não paravam de crescer. Dívidas não só do governo da União, mas também das províncias e municípios do país. Como os saldos comerciais nunca superavam as parcelas, o resultado foi catastrófico. A dívida externa que em 1874 era de $£ \$ 10$ milhões, em 1890 estava em $£ \$$ 59 milhões. Com a queda mundial do preço do trigo nos anos 1890 e a demora necessária para os investimentos em capital fixo e nas melhorias do campo argentino surtirem efeito, o país vai à bancarrota. O principal credor argentino, o banco Baring Brothers cortou novos empréstimos e passou a cobrar as dívidas antigas. Com a recusa do país portenho em quitar compromissos, o banco fechou suas portas e logo depois a Argentina declara a moratória da dívida.

Em conformidade com a teoria dos ciclos de endividamento externo, os hiatos temporais entre a decisão de investimento e a realização dos lucros esperados dos grandes projetos de infraestrutura geraram dificuldades para honrar o serviço da dívida, pois este aumentava

\footnotetext{
${ }^{78}$ ABREU, Marcelo de Paiva. Os funding loans brasileiros - 1898-1931. Revista de pesquisa e planejamento econômico | ppe | v.32 | n.3 | dez 2002. Págs. 516 e 517
} 
enquanto a produção resultante dos investimentos ainda era baixa. Quando tal fato foi percebido pelos investidores estrangeiros, eles pararam de conceder empréstimos, tendo como resultado uma crise de endividamento externo. Assim, o governo argentino não conseguiu cumprir suas obrigações externas, desencadeando uma séria crise financeira. $^{79}$

Preocupados com uma crise sistêmica, a casa Rothschild negocia um acordo para o default argentino: um novo empréstimo é concedido e seriam aceitos os papéis do Banco Baring. Foram cedidos os direitos de aduana argentina e excluíram-se as crescentes dívidas provinciais e municipais. Nos anos que se seguiram o país adotou uma reforma tributária e cumpriu as tradicionais políticas de austeridade. Resultado, além da recessão e desemprego, a dívida argentina crescera para $£ \$ 300$ milhões (30 vezes o valor de 1874 e quintuplicada em relação a 1890).

\subsubsection{A negociação brasileira de 1898}

Foi nessa atmosfera política de submissão e econômica da Crise do banco Baring/ Argentina que o ministro Bernardino de Campos (ainda no governo Prudente de Moraes), buscou uma renegociação na casa N. M. Rothschild \& Sons de Londres.

O crescente endividamento externo nos fins do Império não poderia ser resolvido por uma economia primária e agroexportadora, dependente excessivamente de um produto - o café, que variou sua participação nas exportações do país entre $62 \%$ e $78 \%$ durante a República Velha. Para os liberais ortodoxos, entretanto, a culpa estaria com a tentativa de expansão do meio circulante adotada por Ruy Barbosa nos primeiros 1 ano e meio de governo republicano.

A crise do Encilhamento, traduzida por excesso de papel-moeda no mercado interno e, ao mesmo tempo, por uma desenfreada especulação financeira, nada mais era do que a constante luta política entre bulionistas e anti-bulionistas; papelistas e metalistas; agralistas e industrialistas. Sísifo atinge o cume; a rocha do papel-moeda e da liquidez excessiva rolam à planície. O heroi grego tem de fazer o esforço da austeridade, da ortodoxia deflacionista e carregar o peso das medidas recessivas nas costas. O eterno ciclo vicioso. As oligarquias se protegem, as políticas econômicas se

\footnotetext{
${ }^{79}$ FILOMENO, Felipe Amin. A crise Baring e a crise do Encilhamento nos quadros da economia-mundo capitalista. Economia e Sociedade, Campinas, v. 19, n. 1 (38), p. 135-171, abr. 2010. P. 154
} 
sucedem e a crescente urbanização e o incremento populacional brasileiro se ajeitam entre as expectativas de riqueza não realizadas e as penúrias certeiras.

A incapacidade crônica de quitação das dívidas pretéritas, bem como a falta de investimentos internos que dinamizassem nossas atividades com os empréstimos estrangeiros recebidos, inviabilizavam qualquer possibilidade de quitação e o risco de default era iminente. Fato este levantado por Carmen L. Palazzo:

...uma grande parte das divisas que, desde a Independência, haviam entrado no país, destinavam-se aos serviços da dívida. Dos vinte empréstimos tomados entre 1824 e 1897, apenas seis foram aplicados na construção ou extensão de estradas de ferro e outras obras de infraestrutura... ${ }^{80}$

Para não repetir os erros do caso argentino, as casas bancárias europeias convocam o presidente eleito Campos Salles logo após a vitória. Marcelo de Paiva Abreu dá conta de que a proposta inicial de Tootal, o diretor responsável pelo London \& River Plate Bank, referendadas pela casa N. M. Rothschild \& Sons Limited requisitava, como garantia de um empréstimo de $£ \$ 10$ milhões: a receita de todas as alfândegas da República ( equivalente a exigência feita para a Argentina), a exploração da Estrada de Ferro Central do Brasil, além do serviço de abastecimento de água da capital federal. Obrigava ainda a retirada de circulação, ao câmbio de 12 pence por milréis ( valia 7 dinheiros por mil-réis), do papel-moeda equivalente e, ainda, que essa soma fosse recolhida a determinados bancos estrangeiros e incinerada publicamente. 81 O meio circulante em 1898 estava próximo dos 750 mil contos. A proposta do London \& River Plate retiraria do mercado $50 \%$ do meio circulante. Uma recessão sem tamanho.

Carmen Palazzo reitera que as disputas entre Campos Salles e Prudente Moraes (e seu ministro Bernardino de Campos) sobre a responsabilidade do acordo são desnecessárias. A proposta e a aceitação partiram dos bancos estrangeiros. Não houve novo empréstimo, mas a consolidação das dívidas de 1883, 1888, 1889 e 1895 numa só. Entraram na negociação os juros das estradas de ferro e um empréstimo interno de ouro de 1879. Esse reescalonamento das dívidas e unificação das mesmas, adicionados às novas regras da exploração interna das ferrovias e outros serviços públicos foram

\footnotetext{
${ }^{80}$ PALAZZO, Carmen Lícia.Dívida externa: a negociação de 1898. Casa da Anta Editora. Brasília. 1998 . P.66

${ }^{81}$ ABREU, Marcelo de Paiva. Os funding loans brasileiros - 1898-1931. Revista de pesquisa e planejamento econômico|ppe | v.32 | n.3 | dez 2002. Págs. 515 a 541
} 
essenciais para a vinda de Percival Farquhar para o Brasil. Criara-se com o funding loan uma atmosfera favorável aos negócios e investimentos estrangeiros e reduzira-se o risco de uma bancarrota no país.

Depois de uma longa negociação, Campos Salles apresenta as contrapartidas ao funding loan, com pelo menos três vantagens em relação à proposta inicial:

I. O prazo para o pagamento dos juros das dívidas anteriores pagamento este que, de acordo com o funding, seria feito através da emissão de bonds [era de 2 anos na proposta inicial e foi aumentado para 3 anos]. O país ficava, então, com a folga de mais de 1 ano no qual não precisava remeter divisas para o exterior. $\mathrm{O}$ prazo de amortização era estendido de 2 para 10 anos.

II. O câmbio para o recolhimento do papel-moeda passava ser de $18 \mathrm{~d}$. em vez de 12 dinheiros. Assim, a uma taxa de $18 \mathrm{~d}$. corresponderia maior quantidade de divisas por um determinado valor de mil-réis recolhido do que no câmbio proposto pelos banqueiros, que era de 12 d. ( uma redução de $25 \%$ do meio circulante, [comentário nosso]

III. A exigência de garantias da proposta dos banqueiros ingleses era muito elevada e Campos Salles conseguiu excluir a Estrada de ferro Central do Brasil. Com relação às rendas da Alfândega ficaram reduzidas a sede do Rio de Janeiro. ${ }^{82}$

Os termos finais do acordo foram os seguintes:

Previa-se a suspensão das amortizações de todos os empréstimos incluídos no funding por 13 anos e durante 3 anos seriam lançados, a $100 \%$, títulos do novo empréstimo à medida que maturassem juros de empréstimos e prazos de pagamentos de garantias ferroviárias. O serviço do próprio funding se restringiria a juros até 1911, quando seria iniciada a amortização por 50 anos.

À medida que fossem lançados os títulos do novo empréstimo, seria recolhido o meio circulante equivalente, convertido à taxa cambial de 18 pence por mil-réis, e incinerado em um dos bancos estrangeiros credenciados - London and River Plate Bank, London and Brazilian Bank e Brasilianische Bank für Deutschland (...) Legislação complementar criou dois fundos necessários à execução do programa

\footnotetext{
${ }^{82}$ PALAZZO, Carmen Lícia.Dívida externa: a negociação de 1898. Casa da Anta Editora. Brasília. 1998. Págs. 77 a 79
} 
e aboliu a faculdade emissora do governo. O fundo de resgate do papel-moeda era constituído por receitas em papel do arrendamento de ferrovias federais, pela cobrança da dívida ativa, por rendas eventuais do Tesouro em papel e por saldos orçamentários(...) e o fundo de garantia do papel-moeda depositado em Londres, em N. M. Rothschild \& Sons Limited, que seria alimentado por taxa de $5 \%$ ouro sobre direitos de importação, pelo saldo de taxas em ouro, pelo arrendamento em ouro de ferrovias federais e por rendas eventuais em ouro... ${ }^{83}$

Pouco antes do acordo, ainda como Ministro da Viação e Obras, Joaquim Murtinho tece críticas a condução da política econômica do Brasil que nada mais era do que um programa de governo com a lógica formal dos economistas liberais estrangeiros a ser aplicado futuramente. Nem precisou esperar muito, Campos Salles o nomeia ministro da Fazenda. Para o político matogrossense:

A política republicana vivera sobre duas ilusões perigosas: a crença nas extraordinárias riquezas do Brasil e a confiança na capacidade realizadora do papel inconversível, e que, afinal, se somavam e confundiam como aspectos diversos do mesmo erro de julgamento da realidade dos fatos. Partindo da primeira ideia, os estadistas republicanos tinham julgado possível improvisar a rápida industrialização do Brasil. A elevação das tarifas alfandegárias e as emissões contínuas de notas sem lastro, do Tesouro, eram naturalmente os instrumentos com que os governos poderiam fomentar o progresso material. ${ }^{84}$

Ainda, segundo o "bruxo de Santa Teresa":

...os brasileiros não tinham capacidade de iniciativa e os hábitos de trabalho dos norte-americanos. Ele desprezava, os elementos da grande indústria existentes nos Estados Unidos, frustravam-se aqui todas as tentativas de industrialização. As novas indústrias projetadas ficaram no papel, ou serviam apenas imobilizar parte do capital em circulação, estimular o urbanismo e aumentar as importações, com

\footnotetext{
${ }^{83}$ ABREU, Marcelo de Paiva. Os funding loans brasileiros - 1898-1931. Revista de pesquisa e planejamento econômico | ppe | v.32 | n. $3 \mid$ dez 2002. Págs. 521 a 523

${ }^{84}$ BELLO, José Maria. História da República. pág 163
} 
grave prejuízo para a agricultura, verdadeira fonte de riqueza nacional. $^{85}$

Dessa forma, aceito o plano do funding loan, Murtinho irá colocar em prática seu receituário: a mesma prática da homeopatia positivista, tão em voga no país e da qual nosso ministro-médico era adepto. Centralizava-se no equilíbrio das contas públicas e na redução do meio circulante. Cortavam-se os gastos públicos — nessa época representados pelas obras de infra-estrutura nas grandes cidades nascentes, como: iluminação, fornecimento de gás, sistema de transportes coletivos, ferrovias, água e saneamento - , aumento dos impostos de importação ( condição terrível num país que apenas iniciava sua produção para o consumo interno e dependia demais de mercadorias estrangeiras), políticas deflacionistas e o estímulo a ruralização da sociedade, corte dos fomentos estatais ao desenvolvimento industrial do país.

As consequências foram óbvias: desemprego nas cidades, abandono das obras públicas necessárias à expansão urbana, falências de indústrias nascentes, concentração de renda nas mãos das velhas oligarquias cafeicultoras e claro, cumprimento de todas as medidas financeiras impostas pelos bancos estrangeiros. Décadas depois, quando a ministra Zélia Cardoso lançou um novo plano de contenção, claramente metalista, recebeu o comentário mordaz do político Leonel Brizola de que o governo de então estava amputando as pernas do paciente para estancar um formigamento nos pés. Pelo menos Joaquim Murtinho poderia receitar Arnica.

Palazzo nos revela que um dia antes da saída do poder, Campos Salles recebeu um longo e agradável telegrama dos Rothschild, elogiando a extraordinária mudança do Brasil. Para a historiadora:

O Funding Loan representou, portanto, apenas uma negociação feita nos moldes desejados pelos banqueiros ingleses, mas também uma possibilidade para que o presidente eleito pudesse implementar uma política econômica que era a sua própria receita para a solução dos problemas do Brasil. ${ }^{86}$

\footnotetext{
${ }^{85}$ BELLO, José Maria. História da República. pág 167

${ }^{86}$ PALAZZO, Carmen Lícia. Dívida externa: a negociação de 1898. Casa da Anta Editora. Brasília. 1998. Págs. 94 a 95
} 


\subsubsection{Uma República de Homens}

Duby em seu estudo "Idade Média: Idade dos Homens", mostra como o casamento passou da rejeição à aceitação pela sociedade medieval, transformando-se o matrimônio em evento sacro pela Igreja. Organizaram-se duas formas de casamentos: Os leigos, típico dos aristocratas e com a função de interligar sanguineamente a nobreza e, dessa forma, transmitir seus bens senhorialmente. A outra forma era o casamento cristão, com a função de dessexualizar a mulher e prepará-la para os afazeres domésticos; disciplinar a competição entre os homens e garantir a procriação da espécie. A mulher cabia ainda a virgindade antes e a fidelidade depois do matrimônio. Nenhum destes atributos era exigido dos homens.

A República Velha foi uma república de homens. Não havia participação feminina de nenhuma espécie entre as oligarquias regionais. Às mulheres restava segundo uma das inúmeras revistas ilustradas que surgiram entre os fins do século XIX e início do XX o que se segue:

Aos doze anos, a mulher é a crisálida que espera a luz do amor para tornar-se dourada borboleta; aos treze, é um poema lírico a que falta a última estrofe; aos catorze, é um hino de harpa eólia; aos quinze, é um astro em torno do qual rodopiam a graça, a harmonia e o amor; aos dezesseis, é uma estátua de Madona que procura um coração de homem para dele fazer o seu altar...' E é preciso encontrá-lo com urgência, pois, aos vinte e dois, será 'uma lágrima da noite banhando um túmulo de virgem', ou melhor, uma solteirona... ${ }^{87}$

A Revista Íris publicou este excerto em 1905 em seu número inaugural. Se autodenominava "Revista Mensal de Artes, Ciências, Letras dedicadas à família e a mocidade das escolas".

Decerto que a presença das mulheres na política ainda era restrita, mas várias monarquias tiveram a presença feminina. Catarina II ( 1761-1796) modernizou a Rússia Czarista, Elizabeth I ( 1558-1603) permitiu o florescimento das artes e da pirataria britânica e Vitória ( 1837 a 1901) estabeleceu toda uma era. Carlota Joaquina na colônia teve tanto poder quanto D.João VI. A Princesa Izabel foi regente por três vezes: a primeira de maio de 1871 a março do ano seguinte, período em que aprovou a Lei do

\footnotetext{
${ }^{87}$ Nosso Século, 1900-1910. São Paulo: Abril Cultural, 1980, p.119.
} 
ventre Livre; a segunda entre março de 1876 e setembro de 1877 e a última de junho de 1887 a agosto de $1888^{88}$, nesta regência, ela aboliu a escravidão.

Não há estudos suficientes sobre o assunto, mas na Res publica do café com leite as mulheres eram invisíveis. Ou dissimuladas pelos homens, como diria Machado de Assis.

Joaquim Murtinho, um dos três filhos de família tradicional e rica do Mato Grosso, veio para a capital estudar aos 13 anos. Fixou mansão em Santa Teresa. Seu estudo universitário foi para as Engenharias na escola do exército. Por volta de 1870 cursou medicina na antiga Universidade do Brasil.

Nessa época havia duas linhas de pensamento na ciência médica: a tradicional e a homeopática. A primeira baseava seus métodos em sangrias, conspurcações, cortes e extrações de áreas afetadas. A doença era consequência do sangue contaminado, portanto que se extraísse o mesmo. A outra foi introduzida por Benoit Jules Mure, que tentou montar um falanstério 'fourieriano' em Santa Catarina. Fracassada a proposta, muda-se em 1840 para o Rio e, influenciado pelas ideias de Hahnemann ( o fundador da homeopatia em início do século XIX), aplica a ciência na escola médica do Rio. Entre 1840 e 1911 a homeopatia predominava na medicina brasileira e europeia. Joaquim Murtinho não era nenhum precursor como querem seus biógrafos.

As curas dos escravos pelo método homeopático chamaram a atenção dos senhores e estes aderiram ao tratamento. Dono de excelente oratória, poder político e muito dinheiro, Murtinho aproximou-se da elite política da capital. Tratou o Visconde de Ouro Preto, Deodoro da Fonseca, Ruy Barbosa, Prudente de Moraes, Campos Salles e outros próceres da república. Virou senador e depois ministro da Viação e Obras de Prudente. Conforme crescia sua fama, Murtinho recebia concessões que aumentavam sua fortuna.

A família ganhou a concessão do Banco do Mato Grosso, passaram a ser os maiores acionistas da Companhia Mate Laranjeiras ( maior exportadora mundial da erva mate) e o direito a exploração de ferrovias na estratégica região entre São Paulo e Amazônia. Os Murtinho eram os reis do cerrado. A manutenção do poder coronelístico da família era alicerçada seja com conchavos políticos entre coronéis, ou com extrema violência. Edgar Carone relata as centenas de corpos degolados descendo pelos rios

\footnotetext{
${ }^{88}$ Todas as 3 regências com profundo desagrado ao Imperador. Pedro II perdera seus dois filhos varões e não admitia uma mulher no poder. Mas, quando quedava doente, corria para as plagas europeias para fazer um tratamento médico às custas do Brasil. Por períodos breves de 1 ano a 1,5 ano.
} 
pantaneiros na guerra dos Murtinho, aliados ao general Ponce, para destituir e matar Antonio Paes em 1906.

Joaquim Murtinho mantinha duas faces bem distintas: a do celibatário, meio curandeiro, homem simples cercado de cachorros em Santa Teresa e a do coronel facínora do Centro Oeste. Nas duas ele acumulava capitais e poder político. Em 1898 é alçado ao posto mais importante da vida: torna-se ministro da Fazenda de Campos Salles. Por 4 anos teve uma incumbência: a de aplicar as teorias monetaristas na economia republicana para cumprir as exigências dos Rothschild e do funding loan. $\mathrm{O}$ remédio amargo passou por recessão econômica, redução em $25 \%$ do meio circulante, desvalorização cambial, inflação do mercado interno e incentivos ao café. A teoria Metalista entrava em vigor substituindo os Papelistas da indústria artificial ( como Joaquim Murtinho denominava o capital industrial e financeiro). Nas sábias palavras de Heitor Ferreira Lima:

... Joaquim Murtinho era a expressão mais pura do liberalismo econômico, levado às suas últimas consequências, numa tentativa de análise de um regime agrícola monocultor, de economia periférica, propugnado pela manutenção do status quo, em benefício das classes dominantes. Daí seu repúdio exacerbado e ostensivo à industrialização. Negando sua função progressista e libertadora nos países atrasados, negando o papel da moeda inconversível, cuidadosamente dosado nas nações de crônicos déficits na balança de pagamentos, a rejeição violenta do protecionismo industrial, a repulsa pelas aplicações em atividades manufatureiras... ${ }^{89}$

O poder era tanto que Joaquim Murtinho resolveu presentear uma de suas amantes. Segundo José Murilo de Carvalho ${ }^{90}$, o ministro mandou cunhar a $9^{\text {a }}$ estampa da nota de 2 mil réis com a bela imagem da senhora Prattes. A indignação do deputado Fausto Macedo foi total, afinal além de amante de Murtinho, a moça era conhecida prostituta do Rio.

Para os relativizadores da história, era uma homenagem a Laurinda Santos Lobo, sobrinha de 16 anos e também amante do ministro. Difícil de crer nesta hipótese, pois Laurinda era feiosa e muito diferente da imagem que ficou conhecida como

\footnotetext{
${ }^{89}$ LIMA, Heitor Ferreira. História do pensamento econômico no Brasil. Brasiliana. Volume 360. São Paulo. 1976. Págs. 138 e 139 ${ }^{90}$ CARVALHO, José Murilo de. A formação das almas: o imaginário da República no Brasil. São Paulo. Companhia das Letras, 1990. p.88/89
} 
"Senhorinha”, gravada na nota de 2 mil réis entre 1900 e 1920. Há vários afrescos do pintor Conrad Kiesel, entre eles, um denominado de "Saudade", imagem quase idêntica a da nota em questão. A história numismática trata os afrescos de Kiesel como os de uma bela mulher brasileira. Joaquim Murtinho nunca assumiu a verdade de "Senhorinha", nem que ela existiu e era sua amante, muito menos de que foi por imposição sua que a nota entrou em circulação.

A República Velha era uma república de homens. Homens que escondiam suas mulheres e amantes, que usavam as pessoas por interesses políticos e econômicos. Havia toda uma invisibilidade orgânica das mulheres. Assim, tais homens poderiam cuidar melhor de seus cavanhaques ou bigodes, ou como acidamente afirmou Lima Barreto: “Joaquim Murtinho trata melhor seus sapos do que suas mulheres.”

\subsection{O segundo Funding Loan ( 1914)}

Passados os 4 anos de arrocho econômico do governo Campos Salles e do ministro Joaquim Murtinho e seu remédio amargo, a economia poderia voltar ao ciclo de expansão monetária. Entre 1900 e 1913 os saldos de empréstimos estrangeiros quadruplicaram, com destaque para o aumento da participação do capital de risco francês. Os gastos públicos eram crescentes e a liquidez do mercado internacional ( até 1908) facilitaram as tomadas constantes de empréstimos.

Uma economia não diversificada, dependente de 2 produtos econômicos (café e borracha), endividava-se ano a ano. Quase todos os saldos favoráveis de balança eram utilizados para a quitação de serviços das dívidas, as quais, além do volume crescente, produziam uma dependência crescente do Brasil frente às variações externas do capital. Assim, numa recessão externa como a de 1907, os preços das commodities caíam, os custos da dívida cresciam e, na incapacidade de se quitar as dívidas existentes, emprestavam-se novos capitais.

Despesas federais em sua maioria limitadas. O Brasil do início do século XX possuía pouquíssimas escolas, quase nenhum hospital e um corpo ainda diminuto de servidores públicos. Parte da receita era utilizada para a construção da infra-estrutura urbana em algumas grandes cidades como o Rio e São Paulo. A estrutura fiscal também era precária, limitando-se aos impostos sobre as exportações e importações. Nos períodos de valorização cambial taxava-se mais as importações, o que trazia insatisfação popular devido a grande dependência de produtos estrangeiros para o consumo interno. Por outro lado, nas fases de desvalorização cambial, os altos lucros das exportações 
permitiam uma taxação maior destes setores. Sísifo subindo e descendo o morro. Incansavelmente, boa parte dos cafeicultores ganhava sempre: na baixa pela exportação do café e na alta pela valorização da produção interna, controladas em sua maioria pelos mesmos barões do café.

Em 1910 as receitas federais estavam em 524,8 ( 1000 contos de réis) e as despesas em 623,5. As vésperas da Guerra as receitas subiram para 654, 4 ( 1000 contos de réis). As despesas por sua vez cresceram mais de 20\% e foram a 763 ( 1000 contos de réis). Nos anos da Guerra as receitas caíram bastante: 423 (1914), 404 (1915), 478 (1916), 537 (1917) e 618 (1918) ${ }^{91}$. As despesas inicialmente tiveram leve queda, depois subiram 766 ( 1914), 688 (1915), 686 (1916), 801 ( 1917), 867 (1918) ${ }^{92}$. A média dos déficits nos 5 anos da Grande Guerra atingiu 269 ( 1000 contos de réis). Não podemos nos esquecer que entre 1910 e 1914 tivemos o governo Hermes da Fonseca, o qual investiu quantias consideráveis na modernização do exército, além dos custos elevados da repressão às rebeliões populares, como a do Contestado, boa parte da área em litígio controlada por Farquhar.

Some-se a isso a retomada dos pagamentos dos serviços da dívida ( suspensos desde o primeiro Funding); as constantes quedas do preço internacional do café; as primeiras safras de borracha colhidas no sudeste asiático, minando rapidamente o monopólio brasileiro do setor. A crise econômico-financeira se avolumava.

O importante estudo de Marcelo de Paiva Abreu esclarece os fatos que levaram ao $2^{\circ}$ funding:

...A partir de 1912, o Brasil enfrentou uma sucessão de eventos que transformaram radicalmente a posição do seu balanço de pagamentos. O serviço da dívida havia sido retomado a partir de 1909. As exportações de café reduziram-se com a queda de preços decorrente da venda de estoques nos Estados Unidos, determinada pela justiça norte-americana em decisão com base no Sherman Act. As exportações de borracha caíram rapidamente, em vista do impacto da entrada no mercado mundial da borracha plantada asiática. Tornou-se difícil o lançamento de empréstimos brasileiros com a deterioração política na Europa, especialmente nos Bálcãs. Uma missão financeira enviada ao Brasil por N. M. Rothschild \& Sons Limited no segundo semestre de 1913 voltou muito mal impressionada e disposta a

\footnotetext{
${ }^{91}$ Sempre em mil contos de réis

${ }^{92}$ Sempre em mil contos de réis
} 
recomendar que qualquer ajuda financeira fosse acompanhada de condicionalidades severas $(. . .)^{93}$

Até o último instante do governo Hermes da Fonseca, o acordo foi negociado pelo ministro da Fazenda Rivadávia da Cunha Correa. Considerado um dos precursores da Contabilidade Geral do Brasil, Rivadávia Correa encontrou o balanço do Tesouro praticamente abandonado, afinal o último levantamento realizado retratava o ano de 1905. Sob determinação dele os diretores de contabilidade do Tesouro realizaram os primeiros estudos da Contabilidade Geral do país para apresentar aos banqueiros estrangeiros. Dados estes que:

...foram levantados, tecnicamente, o balanço de Receita e Despesa e o primeiro balanço de Ativo e Passivo elaborado na administração do país, desde o Brasil Colônia. Em fins de 1914, foi redigido o Relatório da Comissão das Partidas Dobradas, junto ao qual estavam os dois já mencionados balanços. ${ }^{94}$

O relatório só foi apresentado no governo seguinte de Wenceslau Brás e mesmo assim, com lacunas devido ao atraso de envio de informações das delegacias regionais. Coube a João Pandiá Callógeras, ministro que sucedeu Rivadávia Correa ( após um breve período de comando interino na pasta), o estabelecimento definitivo da questão com a criação da Seção de Escrituração por Partidas Dobradas ${ }^{95}$

Em outubro de 1914 saía o novo funding de 14,5 milhões de libras. Mais uma vez com os Rothschilds. Os pagamentos de serviços da dívida estavam suspensos por 3 anos e a amortização dos títulos emitidos em Bonds do funding iriam até 1927. Pandiá Callógeras enumera as distinções entre o primeiro e segundo funding:

A começar pelas somas a que se aplicava cada um dêles; cêrca de 33 milhões de dólares o primeiro, e cêrca do dôbro a operação de 1914-17. As responsabilidades da operação do período presidencial precedente ascendiam a 20 milhões de dólares no estrangeiro e mais

\footnotetext{
${ }^{93}$ ABREU, Marcelo de Paiva. Os funding loans brasileiros - 1898-1931. Revista de pesquisa e planejamento econômico | ppe | v.32 | n.3 | dez 2002. Págs.524 e 525

${ }^{94}$ ADDE, Tiago Villac; IUDÍCIBUS, Sérgio de; RICARDINO FILHO, Álvaro Augusto \& MARTINS, Eliseu A Comissão das Partidas Dobradas de 1914 e a Contabilidade Pública Brasileira. Revista de contabilidade financeira. vol.25. №sespecial. São Paulo Sept./Dec. 2014. Disponível em < http://dx.doi.org/10.1590/1808-057x201412030>. Acessado em 17 de outubro de 2016

${ }^{95}$ Este método reza que em cada lançamento, o valor total lançado nas contas a débito deve ser sempre igual ao total do valor lançado nas contas a crédito. Ou seja, não há devedor sem credor correspondente. A todo débito corresponde um crédito de igual valor e vice-versa. Se aumentar de um lado, deve consequentemente aumentar do outro lado também. Como é mais comum uma transação conter somente duas entradas, sendo uma entrada de crédito em uma conta e uma entrada de débito em outra conta, daí a origem do nome "dobrado".
} 
uns 80 no mercado nacional. Os direitos de alfândegas, que ocupam o lugar proeminente nos créditos federais, estavam desaparecendo em virtude da cessão quase completa das importações oriundas da guerra, e assim também as rendas da exportação pertencentes aos Estados, impedidos como se achavam os mares. Uma intolerável crise econômica assoberbava todos os departamentos do trabalho. Novas taxas, era quase impossível criá-las ou cobrá-las. Menos de três anos haviam sido concedidos pelos nossos credores, em 1914, para restabelecer-se a normalidade dos pagamentos. Impossibilidade absoluta de levantar capitais na Europa, pois a guerra os absorvia todos. Por ocasião do primeiro projeto consolidador, ao contrário, o mercado internacional de capitais regurgitava de ouro, e as taxas de juros eram baixas. ${ }^{96}$

Como percebia Pandiá Callógeras, o ministro da Fazenda entre 1915 e 1917, nos anos do primeiro funding a liquidez do mercado internacional era soberba, por sua vez no segundo acordo, o dinheiro além de escasso ainda sofreu o revés da Grande Guerra (o conflito europeu começou 4 meses após o $2^{\circ}$ funding). O comércio no Brasil estava em fase de convalescença: entre 1909 e 1913 existiam 37 empresas norteamericanas no Brasil, com capital de US\$ 1.673.000. Após os três anos do funding (1914-1917) restavam 22 empresas com capital de US\$288.159. Uma retração de mais de $80 \%$ no capital fixo. Uma economia quase monocultora e agrária sofria com a brutal retração do mercado mundial.

As instituições financeiras credoras do Brasil, temerosas de um calote nos pagamentos apresentam um novo plano de reestruturação da dívida:

Em março de 1914, uma conferência de banqueiros liderada por N. M. Rothschild \& Sons Limited, incluindo os principais bancos franceses, bem como Speyer e Schroeder, decidiu ser impossível tomar posição sobre um empréstimo ao Brasil sem informações adicionais. Essas informações foram encaminhadas por José Carlos Rodrigues, enviado especial brasileiro a Londres. A proposta inicial para um empréstimo ao Brasil foi feita, no início de junho, por N. M. Rothschild \& Sons Limited em nome de um numeroso sindicato de banqueiros, que incluía, entre outros, bancos franceses (Societé Générale, Paribas),

${ }^{96}$ CALÓGERAS, Pandiá. Formação histórica do Brasil. Companhia Editora nacional. Rio. 1966. Pág. 221 
bancos alemães (Deutsche, Disconto e Bleichroeder), bem como Warburg, Speyer e Schroeders. De acordo com a proposta inicial dos banqueiros o novo empréstimo pagaria juros de $5,5 \%$ e teria valor nominal de $£ \$ 20$ milhões, com fundo de amortização de $2 \%$ por 24 anos. O preço de lançamento seria em torno de $94 \%$, o sindicato ganharia 5\% e o imposto do selo devido na Grã-Bretanha seria pago pelo tomador. Cupons de juros devidos e bônus sorteados seriam aceitos como pagamento nas alfândegas. Poderia haver uma antecipação de $£ \$ 2,3$ milhões, pagos com os fundos levantados pelo novo empréstimo, mas se ocorresse algo inesperado essa antecipação teria de ser paga em 90 dias. $^{97}$

Depois de longas negociações com os bancos estrangeiros, o ministro Rivadávia Correa manifestava que não poderia aceitar a proposta do sindicato, considerada muito dura, especialmente no que dizia respeito à aceitação de cupons e bônus como pagamento do imposto de importação. O governo brasileiro buscava também reduzir a taxa de juros, aumentar o valor do empréstimo e reduzir o desconto no lançamento dos Bonds, bem como alongar o pagamento da dívida.

Como as dívidas brasileiras se espalhavam entre bancos franceses, alemães, americanos e os velhos Rothschild, as negociações eram mais tensas e havia até um certo nacionalismo na missão brasileira. Segundo Marcelo de Paiva Abreu os bancos estrangeiros preocupavam-se com o “irresponsável nível de gastos” do governo brasileiro. No governo Rodrigues Alves foram os gastos para a remodelação da Capital. Afonso Penna expandiu substancialmente a malha ferroviária, permitindo inclusive a entrada de capital estrangeiro e de Percival Farquhar. Hermes da Fonseca gastou muitos contos de réis no aparelhamento e modernização do Exército. O Brasil não era um bom devedor. Devido ao prolongamento das negociações, a Grande Guerra ( esse assunto será aprofundado no capítulo 6) suspendeu os diálogos, os quais só foram retomados em fins de setembro de 1914. Fechado o acordo de consolidação da dívida externa brasileira, uma nova fase de contenção de despesas, deflação, redução do meio circulante viria:

...O segundo funding loan teria um capital nominal máximo de $£ 15$ milhões, emitido ao par, 63 anos de prazo de amortização com início

\footnotetext{
${ }^{97}$ ABREU, Marcelo de Paiva. Os funding loans brasileiros - 1898-1931. Revista de pesquisa e planejamento econômico | ppe | v.32 | n. 3 | dez 2002. Pág. 525
} 
de resgate em 1927, taxa de juros de 5\%, e seria garantido pela receita da alfândega do Rio de Janeiro e, subsidiariamente, de todas as outras alfândegas da república. Seriam suspensas as amortizações de todos os empréstimos federais denominados em libras ou francos franceses até $1^{\circ}$ de agosto de 1927 e os juros desses empréstimos que vencessem entre $1^{\circ}$ de agosto de 1914 e 31 de julho de 1917 seria refinanciados pelos novos títulos. Ficavam vedadas, também por três anos, a emissão e a garantia de novos empréstimos externos, ou de empréstimos internos com juros pagáveis no exterior. ${ }^{98}$

Sísifo sobe o morro novamente. Completava-se mais um ciclo econômico: recessão ( 1898-1902); retomada ( 1902-1906); expansão ( 1906-1910); declínio ( 19101914) e nova recessão. Não tão exatos assim.

Boa parte da historiografia do período e os historiadores econômicos discutem a lógica do "choque adverso". Teria a Grande Guerra provocado uma expansão da indústria brasileira? Primeiro pela carência de importados, afinal os países ricos estavam em conflito, o que obrigava o mercado interno a suprir essa demanda. Segundo pela abertura de possibilidades com a exportação de bens aos países em guerra. Há um certo consenso de que perdemos essa segunda oportunidade.

Quanto ao mercado interno, Wilson Suzigan ${ }^{99}$ refuta a visão tradicional de que a guerra foi inteiramente positiva; faz a crítica a Warren Dean, que considera a guerra como fator de interrupção do crescimento industrial e, por derradeiro, discorda dos defensores da tese do capitalismo tardio como Paul Singer, os quais entendem ser a guerra positiva tanto para a exportação como para a substituição de importações. Defende mais as teses de Fishlow e Haddad de que houve crescimento entre 1915 e 1917, com retrações em 1914 e 1918.

Todos estes estudos, entretanto, esquecem-se do funding loan e suas políticas econômicas restritivas. A desvalorização da moeda nacional era muito mais uma exigência do acordo do que o fator Grande Guerra. A moeda aviltada favorece as exportações. Mesmo os dados citados da obra de Haddad ${ }^{100}$ comprovando o crescimento industrial podem ser relativizados. Vejamos três dados:

\footnotetext{
${ }^{98}$ ABREU, Marcelo de Paiva. Os funding loans brasileiros - 1898-1931. Revista de pesquisa e planejamento econômico | ppe | v. $32 \mid$ n. $3 \mid$ dez 2002. Págs. 526 e 527

${ }^{99}$ SUZIGAN, Wilson. Indústria brasileira: origem e desenvolvimento. Págs 45 a 59

${ }^{100}$ Apud: SUZIGAN, Wilson. Indústria brasileira: origem e desenvolvimento. Pág. 57
} 
I. Entre os 4 tipos de tecidos temos um acréscimo considerável nos de lã em $1916(+40 \%)$ e 1917 (+28,6\%). Porém, este acréscimo pode estar ligado a um inverno mais rigoroso. Corroborando a suposição temos queda nos mesmos anos dos tecidos de algodão, mais leves. Em 1915 e 1918 a situação se inverte. Outro tecido a crescer em 1917 (+ 39,5\%) foi a juta. Lembrando que os fios de juta eram utilizados para a sacaria do café. Então, tal acréscimo poderia estar ligado ao aumento das exportações apenas;

II. Entre 1915 e 1917 tivemos aumento considerável na produção de chapéus $(15,4 ; 15,6$ e 7,7\%). Todavia em 1914 a redução do setor foi de $35 \%$. Numa escala de 0 100, sendo este em 1913, teríamos 65 em 1914 e 93,38 em 1917. Ou seja, entre 1913 e 1917 a produção de chapéus teve um declínio de 6,62\%;

III. Vinho e aguardente cresceram $133 \%$ e $109 \%$ respectivamente em 1917, entretanto não há dados nos anos anteriores. Em compensação, a bebida mais popular, a cerveja, teve apenas um 1914 bom, com 3 anos de queda. E não podemos esquecer que o mercado de vinho era restrito as comunidades de imigrantes, bastante restrito portanto, o que relativa mais ainda os $133 \%$ de crescimento.

O que esta tese defende é que o baixo crescimento da economia brasileira nos anos da Primeira Guerra tem sua explicação nas políticas recessivas e de contenção do meio circulante, mais do que nos fatores exógenos. É certo que o mercado europeu estava estagnado no período do conflito, por outro lado a economia norte-americana não parava de crescer. Esse fato não poderia ter equilibrado o mercado de importados? A Guerra apenas potencializou, seja o retrocesso da produção industrial como querem alguns, ou a perda de possibilidades como querem outros historiadores. O grande vilão foi o $2^{\circ}$ funding loan e a extrema dependência de nossa economia para com os bancos estrangeiros. A carestia e a recessão decorrentes do funding são os motores da Greve Geral de 1917.

\subsection{O terceiro Funding Loan (1931)}

Passada a recessão de 1923, a partir de 1925 e até 1928, tivemos a recuperação da economia global, os 'anos loucos'. Uma nova bolha financeira se anunciava, o mercado internacional vivia uma crise de liquidez e superprodução ( esse assunto será aprofundado no capítulo 6). O governo brasileiro aproveitou-se dessa situação para expandir os gastos públicos ( nunca os gastos sociais, afinal essa questão era problema da polícia), para tomar novos empréstimos de proteção ao café e endividar-se mais 
ainda, dessa vez com um novo credor: "A peculiaridade da nova onda de endividamento foi a participação dos empréstimos em dólares, que corresponderam, na década, a 75\% das entradas de recursos externos relativos a empréstimos no Brasil.”101

Os primeiros sinais da recessão mundial apareceram nos finais de 1928. A exportação de capitais reduziu drasticamente. Nossa economia, então dependente excessivamente das flutuações externas, foi duramente afetada. Saldos de balança caíram, as contas internas não fechavam, os preços internacionais de nosso produto principal, o café, não paravam de cair.

No ano seguinte a situação piora: a crise da Bolsa de Nova York atinge nossas finanças em cheio. A instabilidade política também era imensa. Júlio Prestes de Albuquerque, candidato das oligarquias tradicionais, derrota o ex-ministro da Fazenda de Washington Luiz, o gaúcho Getúlio Vargas no início de 1930. Vitorioso, o $6^{\circ}$ paulista e $11^{\circ}$ advogado, dos 14 presidentes eleitos da República Velha, parte para a habitual viagem pela Europa dos eleitos, com olhos deslumbrados, costas curvadas e pires na mão. Nesse ínterim estoura a crise política que porá fim a República oligárquica e "seu Julinho" jamais tomou posse, derrubado pela Revolução de 30.

O Banco da Inglaterra indicou Otto Niemeyer, alto funcionário da instituição, para que este visitasse o Brasil. O executivo recomendou — criativamente —, políticas econômico-financeiras restritivas ao governo brasileiro, além de negociar questões que beneficiariam interesses britânicos. Marcelo de Paiva Abreu ressalta que:

... Além disso, teve importância crucial nos entendimentos que conduziram ao terceiro funding loan, bem como, em 1933, na definição da estrutura do novo acordo brasileiro relativo à dívida externa que seria conhecido como 'esquema Aranha', em referência a Osvaldo Aranha, ministro da Fazenda entre 1931 e 1934. Niemeyer, desde o início de 1931, criticou a ideia de que a saída para a crise cambial deveria incluir um terceiro funding loan: alegava que 'o homem que afunda três vezes em geral se afoga', (...) Sublinhava o tamanho da operação necessária, em contraste com a limitada operação de 1898 e insistia que o Brasil necessitava de capital estrangeiro, e que no caso de um funding loan o país estaria se afastando do mercado internacional por um período longo, talvez dez

\footnotetext{
${ }^{101}$ ABREU, Marcelo de Paiva. Os funding loans brasileiros — 1898-1931. Revista de pesquisa e planejamento econômico | ppe | v.32|n.3| dez 2002. Pág 529
} 
anos. Defendia, como alternativa, um programa de austeridade fiscal e monetária que perseguisse o equilíbrio orçamentário e o fim da emissão monetária, além da constituição de um banco central emissor. ${ }^{102}$

Porém a situação brasileira só piorava. Souza Reis ${ }^{103}$ informa que de 1928 a 1932 o índice de permutas entre exportações e importações no Brasil baixou para valores inferiores aos de 1900. As compras externas do país retrocederam aos valores de 1913. Ainda segundo o autor, o café ( então responsável por $75 \%$ de nossas exportações) teve seu valor reduzido constantemente. Para um índice de 100 em 1924 para o valor da saca de café, entre 1930 e 1933 esses valores foram de 54; 38; 44; 38, respectivamente. Uma redução média de $57 \%$ no preço da commodities nos anos iniciais da revolução de 30. Diz Souza Reis que a recessão mundial era uma:

... uma crise com taes efeitos trouxe para o Brasil um período de empobrecimento, cujas manifestações são evidentes na debilidade de seu mercado cambial, na redução das rendas publicas, na superabundancia de circulação monetaria inconversível e na relativamente pequena expansão de seus mercados internos.A depressão do commercio internacional no paiz foi relativamente grande... ${ }^{104}$

Para Júlio Prestes o acordo era inevitável. O governo "revolucionário" de Getúlio não viu outra solução melhor do que a de procurar auxílio estrangeiro. Bello é taxativo ao analisar os motivos do $3^{\circ}$ Funding Loan:

...O Govêrno emergido da revolução propunha-se, como todos os outros congêneres, a corrigir os erros, coibir os abusos, punir os delitos do que o antecedera, restaurar a ordem, a probidade e a competência, abrindo à Nação, na velha frase gongórica, as largas perspectivas de radiante futuro(...)Com o seu primeiro ministro da fazenda, o banqueiro paulista José Maria Whitacker, a direção do Govêrno Getúlio Vargas cingiu-se aos rumos clássicos, na tradição de Joaquim Murtinho; contenção de despesas e aumento de impostos. O que permitiu o equilíbrio orçamentário. Sem embargo da diminuição das rendas públicas. Para manter o serviço da dívida externa, utilizou-

\footnotetext{
${ }^{102}$ ABREU, Marcelo de Paiva. Os funding loans brasileiros - 1898-1931. Revista de pesquisa e planejamento econômico | ppe | v.32|n.3| dez 2002. Pág 530

${ }^{103}$ SOUZA REIS, F.T.. Funding loan de 1931. Rio. Typograffia do Jornal do commercio. Rodrigues \& c. de 1934. Págs. 8 e 9

${ }^{104}$ Idem. Ibidem. Pág 6
} 
se o resto de ouro existente no Banco do Brasil e na caixa de Estabilização, tal como fizera para sustentar o câmbio o Govêrno anterior; iniciara também as negociações para o terceiro empréstimo de funding no valor de $£ \$ 20$ milhões. O 'esquema Oswaldo Aranha'... ${ }^{105}$

Fechado mais um acordo de consolidação das intermináveis dívidas brasileiras, estas eram as condições:

...O funding foi lançado em duas séries, ambas com taxa de juros de $5 \%$, que previam resgate em 20 e 40 anos, dependendo da garantia de cada empréstimo cujos juros estavam sendo refinanciados. Para os empréstimos em dólares, foram lançados apenas títulos de 20 anos. O total do lançamento estava limitado a cerca de $£ 18$ milhões para refinanciar os juros dos empréstimos federais que vencessem a partir de outubro de 1931 por três anos (...). O serviço dos fundings anteriores seria mantido inalterado. O acordo incluía a provisão de recursos correspondentes a pagamentos não-realizados em moeda estrangeira relativos a juros e amortizações, convertidos à taxa de 6 pence por mil-réis, que seriam depositados no Banco do Brasil e destinados a amortizações extraordinárias da dívida externa, ou, 'enquanto não for possível adquirir as cambiais', a compras de títulos públicos.... ${ }^{106}$

A história se repete. Carmen Palazzo nos mostrou como após o primeiro funding e as políticas recessivas de Joaquim Murtinho e Campos Salles, os bancos internacionais mandavam telegramas e cartinhas elogiosas. José Maria Withaker e Getúlio também receberam seus agradecimentos dos Rothschild:

... é importante, no momento, tanto sob o ponto de vista dos portadores de titulo como do governo, que melhore o suprimento do cambio estrangeiro e a confiança, tanto externa como interna, dos que desejarem aplicar capitaes no Brasil e esta confiança só poderá ser obtida se a política sagaz, iniciada pelo Governo actual, de equilíbrio orçamentário, fôr plenamente mantida... ${ }^{107}$

\footnotetext{
${ }^{105}$ BELLO, José Maria. História da República. Pág. 301

${ }^{106}$ ABREU, Marcelo de Paiva. Os funding loans brasileiros - 1898-1931. Revista de pesquisa e planejamento econômico | ppe | v.32|n.3| dez 2002. Pág. 532

${ }^{107}$ SOUZA REIS, F.T.. Funding loan de 1931. Rio. Typograffia do Jornal do commercio. Rodrigues \& c. de 1934. Pág 43
} 
Withaker é substituído por Oswaldo Aranha, mas as condições do acordo permanecem as mesmas: submissão aos interesses do capital financeiro externo. Um novo ciclo estava caracterizado: recessão (1914-1918); retomada ( 1918-1922); expansão ( 1925 a 1928); declínio ( 1929-1931) e nova recessão. Os tempos foram quase iguais: do primeiro funding para o segundo passaram-se 16 anos e deste para o terceiro 17 anos. Entre os 3 reescalonamentos, diversas novas dívidas foram assumidas e quase sempre, pagas em parte, aumentando-se o endividamento. Os empréstimos novos eram tomados na maioria das vezes para quitar-se serviços das dívidas pretéritas. Os fundings nada mais foram do que empréstimos vultosos para pagar dívidas eternas realizadas por governos comprometidos apenas com seus negócios e sua manutenção no poder, a custa do cabresto, da política dos governadores e de uma democracia sem povo.

Alguns anos depois de Getúlio Vargas ( durante o período do Estado Novo) venceu a batalha contra Farquhar e estatizou a empresa deste último, a Itabira Iron. Além disso, decretou a moratória, alegando que só voltaria a pagar os bancos estrangeiros se recursos fossem liberados para o desenvolvimento econômico do Brasil. O calote foi justificado - corretamente, diga-se de passagem —, por Getúlio Vargas da seguinte forma:

Não podemos por mais tempo continuar a solver dívidas antigas pelo ruinoso processo de contrair outras mais vultosas, o que nos levaria, dentro de pouco tempo, à dura contingência de adotar solução mais radical...As nossas disponibilidades no estrangeiro absorvidas, na sua disponibilidade pelo serviço da dívida e não bastando, ainda assim, às suas exigências, dão em resultado nada nos sobrar para a renovação do aparelhamento econômico, do qual depende todo o progresso nacional... ${ }^{108}$

A República Velha morria pela segunda vez. Sísifo carregou a imensa pedra do estado brasileiro por três vezes. Todas as vezes ela rolou morro abaixo, destruindo os pobres mortais e preservando os interesses dos deuses no Olimpo, sorvendo suas xícaras de café, o néctar brasileiro.

${ }^{108}$ VARGAS, Getúlio. A nova política do Brasil.1938, volume V, pág. 27. Rio de Janeiro: José Olympio Editora, 1938. 


\section{CAPÍTULO 4 - IMPÉRIO DO CAFÉ (1905 a 1914)}

“Chamai-me Ismael” é o início da obra Moby Dick de Herman Melville. Nela, o narrador-personagem, um jovem marinheiro sai em busca de uma nova aventura. Após descer na ilha de Nantuck - pátria dos marinheiros valentes —, procura um barco até terminar por subir no 'Pequod', um baleeiro de propriedade de dois capitães distintos e contraditórios: Peleg e Bildad. Na história bíblica, Peleg é descendente de Noé e filho de Éber. Durante sua vida a terra teria sido dividida em 4 continentes. Bildad, por sua vez, é um dos três amigos de Jó. Defende que a causa da perdição de Jó era culpa de seus filhos, afinal todo homem é um verme.

Dentro da nau, viagem a caminho, Ismael encontra o verdadeiro capitão, Acab. O destino: a imensa cachalote branca Moby Dick. O personagem atormentado de Acab (Ahab em outras traduções) será o contraponto de Ismael no conflito com a baleia. $\mathrm{O}$ capitão é monotemático. Toda sua vida e morte foram dedicadas ao combate à imensa Moby Dick. Percival Farquhar foi monotemático. O Brasil era sua Moby Dick. Não perdeu uma perna em 1914 no Brasil, mas todos os seus negócios do império da sua Brazil Raylway. Persistiu, primeiro por 20 anos com a Itabira Iron e por mais alguns anos com a Acesita. Viveu e investiu no país do café por quase 50 anos. Farquhar era quacre como os mitos-personagens Bildad e Peleg. Os dois capitães do navio Pequod aparecem descritos assim por Melville:

...Ora, Bildad, como Peleg, e de fato muitos outros nantuckenses, era
quacre, pois a ilha foi de início povoada por adeptos dessa seita; e até
hoje seus habitantes, em geral, conservam em proporção invulgar as
características do quacre, apenas varia e anormalmente modificadas
por coisas a um só tempo alheias e heterogêneas. Pois alguns desses
quacres são os mais sanguinários dos marujos e baleeiros. São quacres
combatentes; são quacres vingativos. ${ }^{109}$

Bildad é de formação religiosa tradicional, diferentemente de Peleg. Homem prático, Bildad encontrara uma bela forma de perdoar as atrocidades cometidas em décadas de navegação, “ a religião de um homem é uma coisa, e a vida prática outra bem diferente". Peleg é intransigente como o mito bíblico. Farquhar enfrentou um país

\footnotetext{
${ }^{109}$ MELVILLE, Herman. Moby Dick. Nova Cultural/ Círculo do Livro. São Paulo. 1994. Pp. 102-104
} 
repleto de políticos, empresários e jornalistas tão mesquinhos quanto o amigo de Jó. Para eles, Farquhar era um gusano, um polvo do imperialismo estrangeiro a surrupiar nossas riquezas.

O biógrafo de Percival Farquhar, Charles Anderson Gauld, escreveu um panegírico ao empresário quacre, como os armadores nantuckenses. Sua imponente biografia, com portentosa pesquisa de fontes - a maioria delas inexistentes no Brasil, inexplicavelmente —, desnuda toda a carreira do investidor e capitalista norteamericano, captando em várias passagens as contradições inerentes do personagem histórico.

Farquhar é quase sempre visto como um empresário sério, compenetrado, seguidor da doutrina religiosa quacre. Seus negócios fracassaram diversas vezes por uma somatória de erros e alguns deles de responsabilidade de nossa elite política e econômica, de um nacionalismo rasteiro e xenófobo. Artur Bernardes, ex-presidente, depois deputado mineiro, passou toda a década de 30 destruindo as possibilidades econômicas da Itabira Iron de Farquhar, tudo em nome da "pátria" e da "independência do Brasil", entretanto era o mesmo Artur Bernardes que fora presidente do país entre 1922 e 1926 e selara um acordo nada nacionalista com a Belgo-Mineira.

As polêmicas atividades empresariais no Brasil e em outros países da América Latina, como Guatemala e Cuba, foram permeadas de desastres humanos e naturais ocorridos nas construções das ferrovias Madeira-Mamoré e do Sul e conflitos sociais como o do Contestado ( 1912-1916). O pesquisador brasilianista Charles A. Gauld (nascido em Portland em 1911 e falecido em Miami em 1977, cidade em que era professor do Miami Dude College), visualiza em seu biografado a dubiedade de Bildad, um homem avesso ao derramamento de sangue, mas que “...vertera com seu casaco justo, barris e barris do sangue de Leviatã...”.

Nossa história é especialista em esquecimentos e na repetição de mitos produzidos pelas elites. Farquhar foi um deles. Assis Chateaubriand, o proprietário dos Diários Associados considerava que, ao lado do Barão de Mauá e do Conde Matarazzo, Percival Farquhar foi um dos nossos três maiores empresários. Os dois primeiros receberam títulos de nobreza, deram nomes a ruas, praças, avenidas, cidades, universidades. Farquhar ainda é desconhecido dos brasileiros.

Neste quarto capítulo serão abordadas algumas das transformações sociais pelas quais passavam o Brasil no período em que Percival Farquhar iniciou seus 
investimentos no país. O estudo mais aprofundado dos negócios de Farquhar entre 1904 e 1952 vimos no primeiro capítulo.

\subsection{População em Movimento}

O Brasil passa por uma intensa movimentação populacional entre a $2^{\mathrm{a}}$ metade do século XIX até a década de 80 do século seguinte. O nomadismo das camadas mais pobres - por várias vezes de dezenas de milhares —, lenta e constantemente, ocupou uma terra de dimensões continentais.

Ao contrário dos Estados Unidos, onde a expansão Geopolítica num território exíguo fez com que, em poucas décadas, sua dimensão mais que decuplicasse ${ }^{110}$; aqui, a área geográfica era praticamente a mesma, seja na era do Marques de Pombal ou no período de moedas escassas de Joaquim Murtinho. Não havia necessidade de colonizar o anteriormente estabelecido.

O latifúndio era a regra e a ocupação à beira-mar, num primeiro momento, ou a partir do século XVII descendo pelos meandros dos rios, a forma. Aos poucos foram sendo traçadas as linhas demarcatórias. Arranhávamos a costa como disse Frei Vicente de Salvador em 1627:

Da largura que a terra do Brasil tem para o sertão não trato, porque até agora não houve quem a andasse, por negligência dos portugueses que, sendo grandes conquistadores de terras, não se aproveitam delas, mas contentam-se de as andar arranhando ao longo do mar como caranguejos. ${ }^{111}$

Mas, como dito, os portugueses e jesuítas também serpentearam os rios. E os setores médios, após a Independência, buscaram as terras devolutas e apossaram-se do sertão. Não como caranguejos, mas riscando suavemente o mapa do interior do país.

Desde princípio dos Setecentos, escravos fugidos ganharam as matas em busca da liberdade. Movimentaram-se pelas terras brasileiras, dinamizaram as atividades econômicas. Tome-se como exemplo o Quilombo dos Palmares. Formado nos inícios do século XVII, no atual sertão alagoano, então Capitania de Pernambuco,

\footnotetext{
${ }^{110} \mathrm{Na}$ Independência em 1776, a área territorial dos Estados Unidos era de aproximadamente $800 \mathrm{mil} \mathrm{km²}$. Pelo Tratado de Paris assinado entre a Inglaterra e o novo país, as antigas 13 colônias iniciaram sua rápida expansão. O "Destino Manifesto" genial criação dos "pais-fundadores" da Nação, era uma justificativa para a conquista Geopolítica. Por meio de anexações, compras de territórios ( como o Alasca da Rússia), guerras expansionistas ( contra o México) e extermínio das civilizações indígenas, pouco mais de um século depois, os Estados Unidos possuía uma dimensão de pouco mais de 9,3milhões de $\mathrm{km}^{2}$, um exponencial crescimento de $1200 \%$. Colonizar era uma necessidade da ocupação e conquista.

${ }^{111}$ SALVADOR, Frei Vicente de. História do Brasil ( 1500-1627). $7^{a}$ ed. Editora Itatiaia/ Editora da Universidade de São Paulo. 1982. São Paulo. Pág. 59
} 
teve sua população calculada em 35 mil habitantes entre 1624 a 1654. O primeiro censo oficial brasileiro realizado dois séculos e meio após Ganga Zumba liderar Palmares, apresenta São Paulo com 31.385 pessoas ( dados de 1872). Palmares seria uma metrópole para os padrões populacionais da segunda metade do Século XIX. Além de Palmares existiam dezenas de quilombos espalhados pelo interior do país, ao longo de 3 séculos de histórias.

O crescimento populacional foi lento, mas a expansão das fronteiras econômicas e territoriais intensa. Entre 1872 e 1920 foram realizados 4 grandes Censos Populacionais oficiais. No primeiro deles, havia 9.930.478 habitantes no país. Dezoito anos depois o Brasil crescera 44,34\% e contabilizava 14.333.915 de pessoas. O Censo de 1900 anotava 17.438.434 de habitantes. A Campanha Civilista e a luta política no Brasil cancelaram o Censo de 1910; uma década depois, o país possuía 30.635.605. Um número muito distante das grandes nações industrializadas do mundo. Em 1920, os Estados Unidos, por exemplo, contavam com mais de 102 milhões e a Rússia com 130 milhões de habitantes. Uma das justificativas encontradas para a necessidade da imigração sempre foi nossa carência de mão-de-obra. E é sempre disso que se trata a imigração: um movimento de grande contingente de mão-de-obra barata e abundante para edificar os edifícios do Capital.

Destes Censos, apenas dois deles fizeram o levantamento por cor. E mesmo o segundo deles sendo em 1890, percebemos um crescimento numérico e percentual dos brancos e um incremento considerável da população de pardos. Quanto aos negros, sua participação proporcional em relação ao total da população brasileira entre em declínio, seja por conta do fim do Tráfico Negreiro, como da Abolição.

Tabela 1 - Distribuição Étnica da População Brasileira

\begin{tabular}{|c|c|c|c|}
\hline & Brancos & Pardos & Negros \\
\hline 1872 & $3.787 .289(38,13 \%)$ & $4.188 .737(42,18 \%)$ & $1.954 .452 \quad(19,68 \%)$ \\
\hline 1890 & $6.302 .198 \quad(43,96 \%)$ & $5.934 .291 \quad(41,4 \%)$ & $2.097 .426 \quad(14.63 \%)$ \\
\hline
\end{tabular}

Existem dados oficiais também sobre a população escrava no Brasil. Eles permitem avaliar a migração interna do trabalhador forçado. 
Tabela 2 - Distribuição da População Escrava Brasileira

\begin{tabular}{|r|r|r|r|r|}
\hline Extremo Norte & \multicolumn{1}{l|}{ Nordeste } & \multicolumn{1}{l|}{ Sudeste } & \multicolumn{1}{l|}{ Centro/ Sul } & \multicolumn{1}{l|}{ Período } \\
\hline 101.000 & 734.000 & 745.000 & 95.000 & 1864 \\
\hline 107.608 & 435.687 & 856.459 & 140.803 & 1874 \\
\hline 70.394 & 301.470 & 779.174 & 89.757 & 1884 \\
\hline 43.981 & 171.747 & 482.571 & 25.070 & 1887 \\
\hline
\end{tabular}

Fonte: REIS, J. J. Presença Negra: conflitos e encontros. In: INSTITUTO BRASILEIRO DE GEOGRAFIA E ESTATÍSTICA. Brasil: 500 anos de povoamento Rio de Janeiro, 2000. p.91.

Na década de 60 do século XIX dos cerca de 1,6 milhões de escravos (quase $30 \%$ da população brasileira de então), a região Nordeste e a Sudeste concentravam quase o mesmo número de trabalhadores sem liberdade e mais de $90 \%$ dos mesmos. Uma década após, o Sudeste escravizava pouco menos do que o dobro do Nordeste e quase arregimentava perto de $60 \%$ do total do país. A região Sul e Central dobrara percentualmente o número de escravos. São dados que evidenciam o deslocamento - forçado — da população escrava. Mesmo há 4 anos da Abolição, o Sudeste ainda contava com quase o mesmo número de escravos da década anterior. Interessante notar que em 1884 eram quase 1,3 milhões de escravos, quebrando o mito de que o "13 de maio" deu liberdade a poucos negros. O sistema ainda era brutal. Adicione-se a este dado, o fato de que entre 1873-1888 entraram no Brasil, 545.054 imigrantes, a maioria deles para as fazendas de café em São Paulo ou para os cafezais do Sudeste. Pelo menos até o fim do Império, os escravos eram os pés e as mãos dos barões do café.

Mas o grande movimento populacional veio de fora. É consenso entre os historiadores a importância da Imigração no Brasil. Seja pela participação na ocupação territorial; pela oferta de mão-de-obra livre, barata e abundante nos cafezais; ou pelas influências culturais trazidas. Um país distinto e de fronteiras em movimento começava a se formar. Da Proclamação da República até o início da Grande Guerra, oficialmente, entraram pouco mais de 2,6 milhões de imigrantes no Brasil. A grande maioria deles veio para São Paulo ( os dados variam de $65 \%$ a $75 \%$ do total). Mas os imigrantes procuraram desde a região Norte até o Sul, espalhando-se pelo país. Boa parte deles subvencionada, seja pelo governo federal ou pelo governo paulista. Observe-se o movimento de entrada de imigrantes na tabela abaixo: 
Tabela 3 - Movimento de Imigração

\begin{tabular}{|l|r|}
\hline Ano & Entrada de Imigrantes \\
\hline 1889 & 65.165 \\
\hline 1890 & 106.819 \\
\hline 1891 & 215.239 \\
\hline 1892 & 85.906 \\
\hline 1893 & 132.589 \\
\hline 1894 & 60.182 \\
\hline 1895 & 164.831 \\
\hline 1896 & 157.423 \\
\hline 1897 & 144.866 \\
\hline 1898 & 76.662 \\
\hline 1899 & 53.610 \\
\hline 1900 & 83.116 \\
\hline 1901 & 50.742 \\
\hline 1902 & 32.941 \\
\hline 1903 & 44.706 \\
\hline 1904 & 68.488 \\
\hline 1905 & 72.332 \\
\hline 1906 & 57.919 \\
\hline 1907 & 84.090 \\
\hline 1908 & 80.151 \\
\hline 1909 & 133.579 \\
\hline 1910 & 86.751 \\
\hline 1911 & 133.579 \\
\hline 1912 & 177.887 \\
\hline 1913 & 190.343 \\
\hline 1914 & 75.232 \\
\hline TOTAL & 2.672 .955 \\
\hline
\end{tabular}

Fonte: INSTITUTO BRASILEIRO DE GEOGRAFIA E ESTATÍSTICA. Brasil: 500 anos de povoamento. Rio de Janeiro, 2000. Apêndice: Estatísticas de povoamento. p.225. Cálculos feito pelo autor.

Vários historiadores contestam a correção de dado em 1891, 1894 e 1896, os números teriam sido maiores. Independente disso, a presença de imigrantes foi expressiva no período. Tradicionalmente, considera-se que a atração dos imigrantes europeus deu-se unicamente por questões pragmáticas. Precisávamos de trabalhadores para a lavoura, os nacionais não seriam suficientes. Porém, estudos mais recentes tem demonstrado que a escolha pelos europeus trazia também um caráter racial. Era necessário branquear a pela brasileira. $\mathrm{O}$ atraso econômico estaria muito mais na raça inferior de negros e mestiços ( tese desenvolvida por Herbert Spencer, um dos ideólogos de Joaquim Murtinho). O darwinismo social, racista e excludente; a lei do mais forte e apto ( o branco, é claro) estavam por trás dos incentivos imigrantistas, federais e estaduais. 
As classes dominantes não precisavam mais dos negros. $\mathrm{O}$ caminho agora era desprezá-los e destruir o pouco de reputação que lhes sobrara. Na terra do café, o ouro negro deveria ser colhido por mãos brancas. Célia Marinho retrata a medo branco e a onda negra nas palavras do deputado Paula Souza. O racismo escancarado na escolha pelo imigrante:

Discute-se a questão de falta de braços, o paulista entendeu que o negro já era inoportuno, não podia mais ser tolerado na província, aos lados dos nossos foros de povo civilizado, das nossa condições de adiantamento moral e cristão, fechou sua porta e disse - não entra mais negro nenhum.

Quis se abrir algumas frestas por meio de exceções; mas a assembleia levantou-se e disse - Não, a lei é absoluta, não entra mais negro.112

Pesaram ainda os fatores econômicos na escolha pelo estrangeiro livre. Versiani considera que o desprezo pelo negro liberto nada teve a ver com a pretensa ( $\mathrm{e}$ preconceituosa) tese de que o imigrante era mais adequado ao trabalho industrial do que o negro escravo. Primeiro, porque grande parte dos trabalhadores contratados serviam aos cafezais. Segundo, por não haver evidências de que os imigrantes estariam acostumados ao trabalho industrial. Lembrando-se aqui que boa parte destes vieram das regiões pobres e atrasadas da Europa, como os italianos do Norte daquele país, em sua maioria, trabalhadores rurais como os negros e mestiços brasileiros. Por último, aduz que muitos africanos aqui trazidos conheciam a metalurgia. Sem contar que os engenhos e as usinas nordestinas possuíam um sistema razoavelmente desenvolvido (para a época) de equipamentos técnicos e mecânicos. Segundo o historiador:

Em suma, há indicações de que a comparação de custos tenha sido um fator básico na opção entre o trabalho escravo ou trabalho livre, na produção fabril do século passado. Identificar a industrialização com capitalismo, e, por esta via, concluir que a expansão da produção em bases capitalistas trouxe a difusão do trabalho livre ( e a eliminação da escravidão) constitui uma linha de raciocínio de duvidosa base empírica.113

\footnotetext{
${ }^{112}$ AZEVEDO, Célia Maria Marinho de. Onda negra, medo branco. Editora Paz e Terra. São Paulo. 1987. Pág. 167

${ }^{113}$ VERSIANI, Flávio Roberto. Escravos, homens livres e imigrantes: notas sobre a oferta de trabalho para a indústria no período até 1920. In: SILVA,Sérgio \& SZMRECSÁNYI,Tamás. História econômica da Primeira República. Fapesp. Hucitec. São Paulo. 1996. Pág.205
} 
Podemos citar ainda como exemplos dessa movimentação constante de populações e um certo desenraizamento da terra os diversos momentos de migrações internas que persistem até os anos 80 do século XX. Ou nos deslocamentos para o sertão em busca de condições de sobrevivência, longe da miséria, do mandonismo local, do latifúndio excludente ou do Estado que menosprezava a população mais pobre. Foi assim na transumância de cearenses para a região da borracha em fins do século XIX, nos movimentos sociais de Canudos e Contestado, entre outros. Mesmo os imigrantes, por aqui não ficavam muito tempo. Campos Salles estimava em $40 \%$ o número de europeus que, descontentes com as condições impostas no Brasil, retornavam aos seus países de origem.

Por último, não podemos nos esquecer do papel libertador para a Lavoura que teve a Abolição. Primeiro por incentivar essa mobilização da população negra, agora livre e recebendo salários miseráveis, sem a necessidade de que o senhor de engenho ou dos cafezais se preocupasse com a manutenção cotidiana do mesmo. O ex-escravo no Brasil possuía um custo mais reduzido. Segundo, pois o tráfico negreiro e depois o tráfico interprovincial eram dispendiosos. No início do século XIX, um escravo custava cerca de 1 milhão de réis ( 1 conto). O novo trabalhador republicano não custava nada em sua exploração. Liberaram-se os capitais fixos. Terceiro, pois durante muitos anos a exploração do imigrante foi tão acintosa quanto a do negro. A liberdade no Brasil era uma questão de finanças, como sempre.

\subsection{Cidades Novas e Mundo urbano}

Internamente, com a chegada dos Imigrantes em larga escala a partir da década de 1880 e a melhoria das condições alimentares, o país começava seu processo de crescimento demográfico. $\mathrm{O} 1^{\circ}$ Censo Oficial realizado no país contabilizava 9.930.478 habitantes em 1872. O levantamento de 1920 indicava 30.635.605 habitantes no Brasil, ou 308\% de acréscimo em meio século. Entre 1880 e 1900, desceram nos Portos brasileiros 1.684 .746 imigrantes, ou mais de $10 \%$ do total da população do país. Curioso notar que o ano que o Brasil mais recebeu estrangeiros, foi o de 1896, ano do primeiro governo civil da República. ${ }^{114}$

Tal situação foi acompanhada de uma expansão urbana acelerada. Cidades como São Paulo, Rio, Salvador, Recife, Belém e outras, rapidamente passavam das

\footnotetext{
${ }^{114}$ Todos os dados estatísticos foram retirados do órgão oficial brasileiro, o Instituto Brasileiro de Geografia e Estatística (IBGE). Disponível em: <http://brasil500anos.ibge.gov.br/> Acessado em 25/2/2013.
} 
dezenas de milhares de habitantes para as centenas de milhares. A economia era agrária, o mundo cultural ainda o era, mas a vida em cidades, às necessidades distintas do campo, as influências das culturas europeias trazidas pelos imigrantes produziam novas realidades e clamavam por investimentos distintos. Some-se a isto, às profundas transformações ocorridas nas regiões centrais do Capitalismo com a Segunda Revolução Industrial. Transportes coletivos, saneamento básico, energia elétrica, abastecimento alimentar, comércio e uma miríade de novas atividades econômicas dinamizavam o país e introduziam uma nova classe social: a dos investidores e industriais.

A proibição do tráfico negreiro na década de 1850 e a aprovação de decretos paliativos nas três décadas seguintes fez reduzir sensivelmente a população escrava no Brasil. Em 1874 eram pouco mais de 1,5 milhões de escravos no país (metade destes em Rio, São Paulo e Minas Gerais). No ano da Abolição este número girava em torno de 700mil. Três quartos de nossa população eram de pretos e pardos em 1890. A escravidão era um sistema econômico essencial aos latifundiários e a manutenção política do Império. A lenta Abolição ${ }^{115}$ e a não indenização das famílias proprietárias de escravos fez ruir o alicerce político e econômico da Monarquia brasileira.

A progressiva urbanização do Brasil foi outro fator a se destacar no período estudado. Embora a virada qualitativa só tenha ocorrido nos anos 40 ( segundo o IBGE, entre 1940 e 1950, a maioria da população brasileira passou a viver em cidades), o crescimento das cidades grandes e médias e a constante migração do campo para a cidade, bem como a mudança de características espaciais de muitas das antigas zonas rurais em aglomerados urbanos; fizeram o Brasil abandonar — econômica e culturalmente -, o campo.

Em 1872 habitavam as cidades 9,62\% dos brasileiros. Percentualmente, em 1920 a diferença não era tão grande: existiam $11,05 \%$ de cidadãos urbanos. Porém, em termos absolutos o país passou de pouco mais de 950 mil habitantes na zona urbana para quase 3,4 milhões. Um crescimento de quase quatro vezes. Analisando a evolução populacional dentro das capitais percebemos as transformações:

\footnotetext{
${ }^{115}$ A primeira estocada na escravidão foi a Lei Eusébio de Queiroz em 1851, portanto, a Abolição prolongou-se por quase 40 anos.
} 
Tabela 4 - População das Capitais Brasileiras em 1872 e 1920

\begin{tabular}{|l|r|r|c|}
\hline \multicolumn{1}{|c|}{ Capital } & População em 1872 & População em 1920 & $\begin{array}{l}\text { Incremento } \\
\text { Populacional (em X) }\end{array}$ \\
\hline Rio de Janeiro (RJ) & 274.972 & 1.157 .873 & 4,21 \\
\hline São Paulo (SP) & 31.385 & 579.033 & 18,44 \\
\hline Salvador (BA) & 129.109 & 283.422 & 2,19 \\
\hline Recife & 116.671 & 238.843 & 2,04 \\
\hline Belém & 61.997 & 236.402 & 3,81 \\
\hline Porto Alegre & 43.998 & 179.263 & 4,07 \\
\hline Curitiba & 12.651 & 78.986 & 6,32 \\
\hline Fortaleza & 42.458 & 78.536 & 1,84 \\
\hline Manaus & 29.334 & 75.704 & 2,58 \\
\hline Maceió & 27.703 & 74.168 & 2,67 \\
\hline Teresina & 21.692 & 57.500 & 2,65 \\
\hline Belo Horizonte & & 55.563 & \\
\hline João Pessoa & 24.714 & 52.990 & 2,14 \\
\hline São Luís & 31.604 & 52.929 & 1,67 \\
\hline Florianópolis & 25.709 & 41.338 & 1,6 \\
\hline Aracaju & 9.559 & 37.440 & 3,91 \\
\hline Cuiabá & 35.987 & 33.678 & $0,93 *$ \\
\hline Natal & 20.382 & 30.696 & 1,5 \\
\hline Vitória & 16.157 & 21.866 & 1,35 \\
\hline Rio Branco & - & 19.930 & - \\
\hline \multicolumn{1}{|c|}{ TOTAL } & 956.082 & 3.386 .160 & \\
\hline
\end{tabular}

Fonte: Recenseamento do Brazil 1872-1920. Rio de Janeiro: Directoria Geral de Estatística, 1872-1930; e IBGE, Censo Demográfico 1940/2010. Até 1991, tabela extraída de: IBGE, Estatísticas do Século XX. Rio de Janeiro: IBGE, 2007 no Anuário Estatístico do Brasil 1994. vol.54, 1994. Escolha e levantamento do autor.

Salta aos olhos a explosão demográfica em São Paulo. No ano de 1872, a pequena vila bandeirante era apenas a nona maior capital brasileira, com pouco mais de 30 mil pessoas em seu território. Cresceu mais de 18 vezes comparativamente em 1920, o café e a indústria alavancaram a cidade à condição de segunda maior do país.

Curitiba, centro paranaense da madeira e das primeiras fazendas de café do norte daquele Estado multiplica por seis sua população. A Capital Federal, saneada e reformada por Francisco Pereira Passos e Rodrigues Alves, quadruplica seus moradores. Porto Alegre, outro centro decisório político da República Velha tem a mesma evolução. A oligarquia do café-com-leite não estaria completa sem Minas Gerais. Não temos como levantar a variação, pois a nova capital, Belo Horizonte, só foi inaugurada em fins do século XIX ( um pouco dessa cidade planejada será visto posteriormente).

Manaus cresceu bastante entre 1872 e 1910, mantendo-se estável entre 1910 e 1920, o ciclo da borracha se dissipava. Os únicos fatos que destoam foram os casos de 
Aracaju, distante dos grandes centros econômicos ou políticos e a cidade de Cuiabá, única a reduzir seu contingente populacional, talvez pela grande distância do litoral.

Mesmo nas regiões interioranas, o incremento foi vultoso. Muitas cidades do sertão brasileiro tornaram-se maiores do que as próprias capitais de seus estados. Vejamos a tabela elaborada a partir de dados oficiais do IBGE:

Tabela 5 - População das Cidades Brasileiras em 1872 e 1920

\begin{tabular}{|l|c|c|c|}
\hline \multicolumn{1}{|c|}{ Capital } & $\begin{array}{c}\text { População } \\
(1872)\end{array}$ & $\begin{array}{c}\text { População } \\
(1920)\end{array}$ & $\begin{array}{c}\text { Incremento } \\
\text { Populacional (em X) }\end{array}$ \\
\hline Caratinga (MG) & - & 137.017 & - \\
\hline Juiz de Fora (MG) & 38.336 & 118.116 & 3,08 \\
\hline Campinas (SP) & 31.397 & 115.602 & 3,68 \\
\hline Santos (SP) & 9.191 & 102.589 & 11,16 \\
\hline Itaperuna (RJ) & & 90.807 & - \\
\hline Barbacena (MG) & 39.235 & 89.717 & 2,28 \\
\hline Niterói (RJ) & 47.548 & 86.238 & 1,81 \\
\hline Vitória da Conquista (BA) & 18.836 & 84.038 & 4,46 \\
\hline Pelotas (RS) & 21.258 & 82.294 & 3,87 \\
\hline Feira de Santana (BA) & 51.696 & 82.268 & 1,59 \\
\hline Passo Fundo (RS) & 17.444 & 74.646 & 4,27 \\
\hline Diamantina (MG) & 15.974 & 69.445 & 4,34 \\
\hline Ribeirão Preto (SP) & 5.552 & 68.838 & 12,39 \\
\hline Petrópolis (RJ) & 7.209 & 67.574 & 9,37 \\
\hline Macaé (RJ) & 25.149 & 60.280 & 2,39 \\
\hline Santa Maria (RS) & 8.258 & 57.469 & 6,95 \\
\hline Olinda (PE) & 12.419 & 52.199 & 4,2 \\
\hline Ouro Preto (MG) & 48.214 & 51.136 & 1,6 \\
\hline Taubaté (SP) & 20.847 & 45.455 & 2,03 \\
\hline Sorocaba (SP) & 13.999 & 43.323 & 3,09 \\
\hline \multicolumn{1}{|c|}{ TOTAL } & 432.562 & 1.579 .051 & 27,39 \\
\hline
\end{tabular}

Fonte: Recenseamento do Brazil 1872-1920. Rio de Janeiro: Directoria Geral de Estatística, 1872-1930; e IBGE, Censo Demográfico 1940/2010. Até 1991, tabela extraída de: IBGE, Estatísticas do Século XX. Rio de Janeiro: IBGE, 2007 no Anuário Estatístico do Brasil 1994. vol.54, 1994

A cidade mineira de Caratinga foi uma dos maiores centros cafeicultores daquele estado, bem como uma das principais estações ferroviárias por que passava a Central do Brasil. Nos anos 20 era a sétima maior cidade do país. Outras três cidades mineiras de grande importância econômica na Primeira República concentravam um considerável contingente populacional, sendo maiores do que a nova capital Belo Horizonte: Juiz de Fora, Diamantina e Barbacena. Aliás, Belo Horizonte foi o motivo do pequeno crescimento da antiga Vila Rica, a Ouro Preto, que desde 1897 deixara de ser capital mineira. 
Santos com o porto escoador do café e Ribeirão Preto, uma dos principais cidades produtores de café do país, cresceram 11 e 12 vezes, respectivamente. Pelotas e Santa Maria, cidades ligadas a uma indústria nascente em rincões gaúchos, aumentaram 4 vezes seus moradores. Foi o mesmo caso de Sorocaba em terras paulistas, a cidade triplicou nos anos analisados. Itaperuna, terra do café carioca e Niterói, vizinha da capital federal cresceram significativamente. Cidades nordestinas como Vitória da Conquista na Bahia e Olinda também.

Somando-se estas quarenta cidades, as vinte capitais e outras vinte cidades interioranas escolhidas pelo autor, a população passou de 1.388.644 para 4.965.211, num acréscimo de 357,55\%. Representavam mais de $16 \%$ do país em 1920. Novos costumes, novas necessidades, velhos governos e estruturas.

\subsection{A Reconstrução das Capitais}

\subsubsection{Rio de Janeiro: o Bota Abaixo}

Os mineiros resolveram construir uma cidade nova, os paulistas reorganizaram sua velha província, os dirigentes da antiga capital resolveram desobstruir a urbe do passado e purificar as areias do Flamengo e Botafogo.

Então maior cidade do país, o Rio de Janeiro após reformas pontuais e pequenas, adentra o século XX com uma transformação profunda. Rodrigues Alves nomeia prefeito da capital, o engenheiro e urbanista Pereira Passos (1902-1906), o plenipotenciário alcaide contou com as intervenções portuárias de Lauro Muller, a violência do "bota-abaixo" comandada pelo engenheiro Paulo Frontim e o sanitarismo invasivo de Oswaldo Cruz.

Pereira Passos estudou na França entre 1857 e 1860, período em que o Barão George-Eugène Haussmann remodelou e reurbanizou completamente a cidade de Paris. O político e advogado francês, nomeado por Napoleão III, foi prefeito daquela cidade em 1853, governando até 1870. Canalizou e enterrou a água e o esgoto da cidade, construiu parques ( para melhorar o ar e permitir condições de higiene, ele ajardinou e arborizou cerca de 80 quarteirões do centro remodelado), abriu ruas, pontes e as imensas avenidas. A partir do Arco do Triunfo, tendo como ponto de dispersão central a Champs-Élysées, abriu 12 largas avenidas trânsfugas, interligando as periferias da velha urbe à futura 'cidade-luz'. A capital parisiense buscava os ideais higienistas típicos da 
segunda metade do século XIX. O custo social e econômico foi vultoso. "A perspectiva sufocada é a pelúcia para os olhos", comenta Walter Benjamin. "Paris cheira a mofo" diz Louis Veuillot em 1914. As classes operárias foram higienicamente - empurradas ao banho de civilização. "A reconstrução da cidade(...)obrigando os operários a morar em bairros da periferia havia rompido o laço de vizinhança que o ligava ao burguês", completa Levausser em Histoire des classes ouvriéres $(1914)^{116}$. Ou nas palavras críticas a Haussmann:

Havia montanhas em Paris, até mesmo nos boulevards...Faltava-nos água, mercados, luz, nesses tempos remotos que não estão ainda há mais de trinta anos. Alguns bicos de gás mal começavam a surgir. Faltavam-nos também igrejas. Entre as mais antigas e mesmo entre as mais belas, muitas serviam de lojas, casernas ou de escritórios. As outras estavam escondidas por uma quantidade de casebres em ruínas. As estradas de ferro, no entanto, existiam; elas lançavam todos os dias, em Paris, torrentes de viajantes que não podiam nem se alojar em nossas casas, nem circular em nossas ruas tortuosas (...) Ele [Haussmann] demoliu bairros; poder-se-ia dizer, cidades inteiras. Clamava-se que ele traria a peste; ele deixava clamar e nos dava, ao contrário, com suas inteligentes escavações, o ar, a saúde, a vida. Ora era uma Rua que ele criava; ora uma Avenida ou um Boulevard. Ora uma Praça, um Square, uma via de passeio. Fundava hospitais, escolas, grupos de escolas. Trazia-nos um rio inteiro. Perfurava esgotos magníficos.117

Numa cidade endividada por quase duas décadas de gastos excessivos e empréstimos bancários que sufocavam as finanças da mesma, adicionados a uma política de exclusão social e expulsão das classes trabalhadoras, derrubando casas e vidas ( entre 1853 e 1870 Haussmann derrubou cerca de 18.000 edifícios de Paris; segundo o censo de 1851 a cidade possuía pouco mais de 30 mil edificações), provocando uma migração massiva em benefício do embelezamento e higienização. Torna-se mais fácil entender o potencial de revolta e conscientização da classe operária na Comuna de Paris, um ano após o prefeito deixar o poder executivo.

\footnotetext{
${ }^{116}$ Todas as citações são da obra de BENJAMIN, Walter. Passagens. Belo Horizonte/São Paulo: Editora UFMG/Imprensa Oficial do Estado de São Paulo, 2006. págs. 160 a 166

${ }^{117}$ Citado por BENJAMIN, Walter. Passagens. Belo Horizonte/São Paulo: Editora UFMG/Imprensa Oficial do Estado de São Paulo, 2006. Pág. 167. In: SIMON, Jules. Mémoiries du baron Haussmann. 1890.
} 
Volte-se a cidade carioca. Sevcenko afirma que o Rio antes das reformas de Pereira Passos, era "o túmulo do estrangeiro". Existiam focos permanentes de difteria, malária, tuberculose, lepra, tifo, varíola e febre amarela. Além das endemias, o Rio contava com péssimas e arcaicas instalações portuárias.

Cais de baixas profundidades impediam a passagem de grandes navios - mais comuns após o invento do aço na segunda metade do século XIX —, obrigando as embarcações a permanecerem ancoradas à distância e passarem por um complicado e custoso sistema de transbordo.

O terceiro problema eram as ruas tortuosas, de traçados coloniais, com um sistema de transporte de pessoas e mercadorias inviabilizado. Era um Rio iluminado a lampião. Uma cidade de pouco mais de 800 mil pessoas em 1900 com uma estrutura urbana e sanitária medieval.

A ‘tripla ditadura' de Pereira Passos, Oswaldo Cruz e Lauro Muller ( futuro aliado e defensor de Farquhar), segundo Sevcenko, elegeu os casarões, os cortiços e as favelas, recém levantadas pelos egressos de Canudos, como inimigos da higienização e da modernização da capital do país. Inimigos, pois estavam próximos ao porto e impediam a expansão física deste; também por evitarem as aberturas de ruas e avenidas retas, planas e que facilitassem a circulação de mercadorias e por último por — na visão dos ditadores reformistas - exalarem o odor fétido da imundície e das doenças.

O cartão postal do Brasil seria construído a partir do apartheid físico e social dos moradores mais pobres. Nas letras da poesia-música 'O estrangeiro' de Caetano Veloso: “...O antropólogo Claude Levy-Strauss detestou a baía de Guanabara, pareceu-lhe uma boca banguela...”. Tão banguela quanto a sua proposta de história. Dentro dessa proposta de reurbanização:

Iniciou-se então o processo de demolição das residências da área central, que a grande imprensa saudou denominando-o com simpatia de ' a Regeneração'. Para os atingidos pelo ato era a ditadura do 'botaabaixo', já que não estavam previstas quaisquer indenizações para os despejados e suas famílias, nem se tomou qualquer providência para realocá-los, Só lhes cabia arrebanhar suas famílias, juntar os parcos bens que possuíam e desaparecer de cena. $\mathrm{Na}$ inexistência de alternativas, essas multidões juntaram restos de madeira dos caixotes de mercadorias descartados no porto e puseram a montar com eles toscos barracões nas encostas íngremes dos morros que cercam a 
cidade, cobrindo-os com folhas-de-flandres de latões de querosene desdobrados. Era a disseminação das favelas.118

Favelas, cortiços abarrotados, 'zungas' ( locais em que famílias alugavam esteiras e deitavam-se no chão), retratos de uma cidade excludente, na qual centenas de milhares de cidadãos viviam em condições sub-humanas. Para a elite higienista e autoritária somente a invasão de lares e vidas seria indicada para a erradicação das doenças sociais e da varíola. Sevcenko explica que:

(...) foram criados os batalhões de visitadores que, acompanhados da força policial, invadiam casas a pretexto de vistoria e vacinação dos residentes. Se constatassem sinais de risco sanitário, o que naquelas condições era quase inevitável, tinham autorização para mandar evacuar a casa, cortiço, frege, zunga ou barraco, condenando-os eventualmente à demolição compulsória (...) ${ }^{119}$

Numa revolta espontânea, a população pobre, despejada e humilhada, sem saída ou defesa, amotinou-se contra as reformas higienistas, a violência do Estado e a ditadura tríplice dos governantes cariocas.

O combate sanitário da febre amarela despertara resistências, mas sua forma de profilaxia era menos agressiva. Oswaldo Cruz seguiu os modelos "bem sucedidos" da Alemanha e da Itália ${ }^{120}$ : erradicação do agente transmissor do vírus, o mosquito Aedes aegypti $^{121}$, adaptado ao ambiente urbano e isolamento dos infectados. Posteriormente, ele levará seus conhecimentos para a ferrovia Madeira-Mamoré. A revolta popular estourou quando o combate direcionou-se a outro vírus, o causador da varíola. Por ser infectocontagiosa, sua transmissão se dá pelo contato com outro doente ou pela secreção. Outro detalhe é que existia uma vacina preventiva desde o início do século XX. O ministro sanitarista não teve dúvida: invadiu casas para aplicar a vacina obrigatória. Mulheres, crianças eram obrigados a desnudar-se frente a agentes de saúde e receber a agulha compulsória de uma administração que derrubava casas e vidas. Os jornais retratavam a resistência à vacina como provinda de uma "horda de bárbaros".

\footnotetext{
${ }^{118}$ SEVCENKO, Nicolau. O prelúdio republicano, astúcias da ordem e ilusões do progresso. In: SEVCENKO, Nicolau. História da vida privada no Brasil. Volume 3. Cia das Letras. São Paulo. 1998. pág. 23

${ }^{119}$ SEVCENKO, Nicolau. O prelúdio republicano, astúcias da ordem e ilusões do progresso. In: SEVCENKO, Nicolau. História da vida privada no Brasil. Volume 3. Cia das Letras. São Paulo. 1998. pág. 23

${ }^{120}$ Em 1882 os Impérios Alemão e Austro-Húngaro selaram a Tríplice Aliança com o Reino da Itália. Uma reunião de regimes fortes, lideradas por Otto von Bismarck. O modelo sanitarista carioca possuía bons antecedentes

${ }^{121}$ Aedes aegypti literalmente significa " odiento egípcio". Trata-se do mesmo vetor que transmite a dengue, outra doença urbana que atingiu de forma epidêmica o estado de São Paulo em 2015.
} 
Para os donos do poder era apenas o movimento de uma massa ignara resistindo, por desconhecimento científico ou civilizacional, às alterações urbanísticas e sanitaristas para o bem comum. Como Canudos, era uma luta entre o atraso e o progresso. A repressão foi brutal. Primeiro foi o conflito com a polícia do Rio. Como esta fora incapaz de conter a multidão, convocou-se a Guarda Nacional. Depois vieram os bombeiros e a rebelião continuava. Rodrigues Alves convoca o exército e depois a Marinha; derrotas sucessivas. Pediu-se a colaboração da Força Pública de São Paulo e Minas. Com todo esse efetivo combatendo os insurretos e apenas depois de 10 dias de conflito, a rebelião finalmente foi derrotada. A Revolta da Vacina (1904) sofreu o benefício da Ordem positivista:

E teve início a repressão. O chefe de polícia da capital deu ordens para que toda e qualquer pessoa abordada no centro da cidade que não pudesse comprovar emprego e residência fixos, fosse detida. Como a tripla reforma criara um imenso déficit habitacional e como a maioria da população vivia de expedientes temporários, num mercado de emprego instável, esse decreto envolvia praticamente toda a população pobre. Os detidos eram levados para a Ilha das Cobras, onde eram despidos e violentamente espancados, para então ser espremidos nos porões de vapores que partiam incontinenti para a Amazônia. Lá, a pretexto de servir de mão-de-obra para a extração da borracha, os prisioneiros eram despejados no meio da selva, sem qualquer orientação nem guias, sem recursos nem ajuda médica, para desaparecer em meio à floresta. A 'Regeneração' estava completa $(\ldots)^{122}$

As novas elites do país comemoravam a aplicação dos ideais republicanos. O Rio de Janeiro tomava seu 'banho de civilização'.

\subsubsection{Belo Horizonte: Edificar o novo tempo}

Desde a Inconfidência Mineira (1789) havia um movimento por parte da elite de Minas Gerais pela transferência da capital, então na cidade de Vila Rica (posteriormente denominada de Ouro Preto). Quase um século depois, o desejo político torna-se um projeto urbanístico para enterrar o passado:

\footnotetext{
${ }^{122}$ SEVCENKO, Nicolau. O prelúdio republicano, astúcias da ordem e ilusões do progresso. In: SEVCENKO, Nicolau. História da vida privada no Brasil. Volume 3. Cia das Letras. São Paulo. 1998. pág. 24
} 
Um outro fator contribuiu para fortalecer a ideia de mudança. Ouro Preto, cidade histórica, guardava em sua arquitetura uma série de símbolos e marcas do passado colonial que os republicanos queriam enterrar. Com suas ruelas e becos, suas igrejas barrocas e suas casas, porões e senzalas, a velha capital lembrava os anos da dominação portuguesa, das conspirações e da escravidão. Uma nova cidade, planejada segundo os valores modernos, seria o símbolo de uma nova era. ${ }^{123}$

Em 1891, o presidente da província, Augusto de Lima, aprovou um decreto determinando a transferência da capital para um lugar que oferecesse condições adequadas de higiene. O lugar escolhido foi o Arraial de Curral del Rei. A Comissão de Construção, chefiada por Aarão Reis e formada por engenheiros, arquitetos, médicos, advogados e políticos republicanos, projetou e impôs Belo Horizonte. A nova capital foi inaugurada em fins de 1897 dentro dos ideais positivistas de higienização urbana e saneamento das cidades. A cidade é um organismo saudável e racional, seja ele espacial ou socialmente. Coube ao presidente de Minas Gerais, Chrispim Jacques Bias Fortes (1894-1897), político de Barbacena e jurista formado pelo Largo do São Francisco (SP), a inauguração da bela capital mineira. A prática "científica" dos republicanos passava por:

Representações mentais de longa duração, como as de "regeneração" ou de recomeço, coexistem com a tomada de consciência, própria do tempo, de que era preciso romper com o passado, fazer transformações como as que ocorriam por toda parte, adotar medidas modernas de urbanismo, próximas daquelas dos países do “mundo civilizado". ${ }^{124}$

Traçados geométricos e regulares, ruas retas, avenidas largas para facilitar a circulação de mercadorias, pessoas e 'ar saudável'. Tudo isso no centro administrativo. A exemplo da reforma no Rio de Janeiro, a construção mineira também contou com um "Bota-abaixo". Para a edificação de Belo Horizonte, ocorreu a completa destruição do

\footnotetext{
${ }^{123}$ PREFEITURA DE BELO HORIZONTE. BH 100 anos - uma lição de história. $1997 . \quad$ Disponível em:< http://portalpbh.pbh.gov.br/pbh/ecp/comunidade.do?evento=portlet\&pIdPlc=ecpTaxonomiaMenuPortal\&app=historia\&tax=11794 \&lang $=$ pt BR\&pg $=5780 \& \operatorname{taxp}=0 \&>$. Acessado em 15/3/2015

${ }^{124}$ SALGUEIRO, Heliana Angotti. O Pensamento Francês na Fundação de Belo Horizonte: Das Representações às Práticas. In.: SALGUEIRO, Heliana Angotti. (org.) Cidades Capitais do Século XIX Racionalidade, Cosmopolitismo e Transferência de Modelos. São Paulo: Editora da Universidade de São Paulo, 2001. pág.136. Citado por ALMEIDA, Marcelina das Graças de. Morte, cultura, memória — múltiplas interseções. Tese de Doutorado. UFMG. 2007. Pág. 140)
} 
Arraial e a transferência de seus antigos habitantes para outro local. Casas foram desapropriadas, residências demolidas e como os imóveis oferecidos em substituição aos desalojados possuíam preços exorbitantes, obrigou-se a população original a ter de deixar o centro e procurar as periferias do planejamento higienista. Favelas se ergueram, a primeira delas próxima à futura avenida Afonso Penna.

A edificação da primeira capital planejada do país era um ato simbólico dos novos tempos, de Minas e do Brasil. A Vila Rica colonial e a partir do Império, Ouro Preto, terra da mineração e dos ideais independentistas, uma vila provinciana e afastada da capital do país teria de dar lugar ao urbanismo de influência francesa e ao planejamento racional e cientificista dos fins do XIX. Belo Horizonte seria a cidade da higiene, da indústria, a capital das Minas Gerais republicana. ${ }^{125}$ Como sempre, o povo assistiu bestializado a construção. Segundo Alfredo Camarate, um dos engenheiros e idealizadores de Belo Horizonte, nem os mortos foram respeitados:

Há só uma coisa que me constrange e comove, no meio de toda esta lufa-lufa necessária, para fazer surgir, do nada uma capital que deve trazer, desde o nascedouro, todos os resultados benéficos das conquistas deste século - é que, de há dois meses para cá, vejo enterrarem - se, numa cova que mal daria, em tamanho, para o corpo de um recém-nascido, cadáveres, sobre cadáveres; desenterrando - se os crânios dos antigos posseiros, ainda trazendo pedaços de pele pegados ao osso, e isto acompanhado do nauseabundo cheiro de cadáveres mal curtidos, de profanações (que não são outra coisa) com os crânios rolando pela terra onde todos pisam; essa terra que dá ingresso ao Templo de Cristo, que entre todos os respeitos que pregou, também pregou o respeito pelos mortos! [...]

Sei que este tristíssimo episódio que, nestes últimos tempos se tem repetido cinco ou seis vezes, pode perfeitamente ser lançado à conta do passado de Belo Horizonte; mas eu, em todo o caso, protesto contra ele, como cristão e como homem e protesto, com a indignação sincera, de quem lhe dói a alma ou o coração de ver, na quietação e repouso da eterna vida, repetir - se essa constante luta dos humanos e que se

\footnotetext{
${ }^{125}$ Curioso notar que foi um médico e jovem prefeito de Belo Horizonte, depois governador de Minas que fez profundas mudanças urbanas na capital daquele estado. Foi o mineiro Juscelino Kubitscheck, seis décadas depois, levou a capital do país para o meio do sertão goiano e construiu a cidade planejada de Brasília. Semelhante ao caso belo-horizontino, o Plano Piloto projetado por Lúcio Costa e alicerçado pelos prédios idealizados pelo arquiteto Oscar Niemeyer, não previu a permanência dos cerca de 600mil candangos, operários da construção civil e suas famílias que levantaram a capital brasileira. A cidade futurista e pós-moderna tem de conviver com as "cidades-satélites", verdadeiros bantustões brasileiros.
} 
define singela e eloqüentemente, nesta frase popular: 'tira-te, para que me ponha!'

Parece que, em Belo Horizonte, a luta pela vida se prolonga, continua e emenda, na luta pela cova! 126

\subsubsection{São Paulo: uma reforma dentro da ordem.}

Por doze anos Antônio da Silva Prado foi prefeito de São Paulo ( 1899-1911). Dono de uma das maiores fortunas do país, empresário de setor ferroviário e de vidros (fundou a Fábrica Santa Marina), cafeicultor ( somente na fazenda São Martinho ele controlava mais de 3 milhões de pés de café) e investidor do mercado imobiliário e financeiro. Vieram dele duas políticas de reorganização da capital paulista: a irradiação monocêntrica e o zoneamento espacial.

A primeira objetivava ligar o centro da cidade aos bairros periféricos, os quais, abastecidos pelo sistema de bondes introduzidos em 1900, poderiam alocar a população imigrante que crescia vertiginosamente na capital paulista - Antonio Prado, como empresário, também subvencionava a vinda de imigrantes. Por sua vez, o zoneamento é a divisão da cidade por rendas e classes sociais. Ambos os projetos propunham profundas transformações nos traçados de ruas, avenidas e bairros. Por meio de demolições, alargamentos, calçamentos, retificações, ajardinamentos e arborização, todos necessários ao ideal de higiene pública.

Não é à toa que o bairro planejado da nova elite foi denominado de Higienópolis. Uma região dotada de todos os serviços públicos disponíveis à época e bem distante dos cortiços e habitações precárias do centro, hábil para propiciar a profilaxia das doenças, infecciosas e sociais do início do século XX. Assim:

A preocupação com a higiene pública esteve sempre presente no desenvolvimento urbano até pelo menos a Primeira Grande Guerra. Originou-se das tentativas de atender às soluções referentes à descoberta de que a limpeza, a aeração, a luz solar e o verde são tão importantes para a saúde e sobrevivência do corpo humano como o pão e a água. Assim, valorizaram-se as praças, o ajardinamento, a arborização, como formas de suprir essas necessidades, e evitarem-se os surtos epidêmicos das moléstias transmissíveis. Ao mesmo tempo,

\footnotetext{
${ }^{126}$ CAMARATE, Alfredo. (pseud. Alfredo Riancho). Por Montes e Vales (...) págs. 79,80. Revista do Arquivo Público Mineiro. Belo Horizonte, Ano XXXVI, 1985. Citado por ALMEIDA, Marcelina das Graças de. Morte, cultura, memória — múltiplas interseções. Tese de Doutorado. UFMG. 2007. Pág. 146
} 
era imprescindível a dispersão dos aglomerados urbanos, temidos como focos dessas moléstias. Os governos estaduais organizaram seus serviços sanitários e elaboraram códigos de higiene, baseados na medicina e na engenharia sanitária, que incluíam a pesquisa científica e campanhas de limpeza e de vacinação da população. Para o governo da República recém proclamada, o grande alvo seria "o emprego dos meios tendentes a impedir a importação das moléstias epidêmicas e a disseminação das já existentes" no meio tropical, com o objetivo de criar condições para atrair capitais, mão-de-obra e técnicos estrangeiros. A higiene pública implicava o "controle políticocientífico do meio". Caberiam ao Estado os serviços de saneamento de água e, às Prefeituras, o de terra, devendo estas formular suas leis dentro dos padrões exigidos pelos códigos sanitários e apresentar a cópia de todos os projetos de obras públicas e particulares ao Serviço Sanitário do Estado, submetendo-os, antes de mais nada, à aprovação deste. $^{127}$

Antonio Prado remodelou o traçado urbano de São Paulo. E como Pereira Passos no Rio, contou com um sanitarista: Emílio Ribas, o médico responsável pela implantação do Serviço de Higiene paulista entre 1898 a 1917. A capital bandeirante também era o nó das estradas de ferro, o entroncamento que levava o café do interior até Santos, isto desde a segunda metade do século XIX. A pequena província de $30 \mathrm{mil}$ habitantes em 1872 multiplica por dez sua população em 1910. O comércio intenso, as fábricas nascentes, as vilas operárias, o sistema financeiro começando a fervilhar, a eletricidade, a telefonia e os bondes davam uma nova face à cidade do café.

Fransérgio Follis ao descrever esse rápido processo paulistano afirma que: ...a modernização da estrutura sanitária da cidade de São Paulo, executada pelo prefeito Antônio Prado em consonância com a política do Serviço Sanitário do Estado, dirigido pelo Dr. Emílio Ribas, na administração de João Teodoro Xavier de Matos (1872-1875), gastouse no embelezamento da capital uma quantia aproximadamente igual à metade do orçamento anual da província. Muitas ruas novas foram abertas e antigas ruas estreitas foram alargadas por meio de

\footnotetext{
127 HOMEM, Maria Cecília Naclério. Antônio da Silva Prado, prefeito da cidade de São Paulo: 1899-1910. Laboratório de Fundamentos da Arquitetura e do Urbanismo. FAU-USP. V Seminário de História da Cidade e do Urbanismo. "Cidades: temporalidades em confronto". Uma perspectiva comparada da história da cidade, do projeto urbanístico e da forma urbana. PUCSP. 1998
} 
desapropriações e demolições de muitos prédios coloniais. Em 1873, as ruas que formam o triângulo central foram calçadas com paralelepípedos. A Várzea do Carmo foi drenada e um novo jardim público, denominado Ilha dos Amores, foi traçado numa pequena ilha do Tamanduateí. Em 1872, os lampiões a querosene das ruas foram substituídos pela iluminação a gás. Em 1888, foram instaladas as primeiras luzes elétricas nas ruas do centro da cidade. Segundo Morse(1970), no final da década de 1880, São Paulo contava com o melhor sistema de água e esgotos do Brasil. No início da década de 1930, começa a ser implantado o Plano de Avenidas de Prestes Maia que viria a dar à cidade uma nova configuração espacial. ${ }^{128}$

Os lampiões a gás da inglesa San Paulo Gaz Company Ltd. aos poucos são substituídos pela eletricidade da canadense e americana São Paulo Tramway Light \& Power Co. ( que irá pertencer a Percival Farquhar). Os carris de tração animal dos bondes $^{129}$, lentos e pequenos, deram lugar com o tempo aos trens e bondes elétricos, mais rápidos e espaçosos. As linhas de bonde ligavam o centro aos bairros e as principais redes ferroviárias do estado que se entrecruzavam na capital bandeirante. Mais de 20 milhões de passageiros foram transportados pelos bondes em 1906, permitindo liberar o centro da população trabalhadora, pois esta passou a residir nos bairros distantes, nas vilas operárias ou nos aglomerados de imigrantes da mesma nacionalidade.

$\mathrm{O}$ abastecimento de água era garantido pela Cantareira. O lazer dos parques e praças como o da Luz e da República ( antigo Campo dos Curros), era completado pelas primeiras salas de cinema. A inauguração do Teatro Municipal (1911), as corridas no hipódromo e as partidas de futebol do campeonato paulista (iniciado em 1902). Havia toda uma cidade em transformação para receber os novos moradores e a economia urbano-industrial nascente. Antonio Prado era um modernizador urbano numa mente conservadora. Em viagens à Europa costumava buscar “ um banho de civilização" e "se

\footnotetext{
${ }^{128}$ FOLLIS, Fransérgio. Modernização urbana na Belle Epóque paulista. São Paulo. Editora Unesp. 2004. Pág. 33

${ }^{129}$ A origem da palavra Bonde se deve ao fato de que a passagem do Carril de Ferro custava 200 réis, mas não existiam moedas ou cédulas deste valor em circulação. Dessa forma, a empresa teve a ideia de emitir pequenos cupons (bilhetes), em cartelas com cinco unidades, ao preço de mil réis. Os bilhetes eram impressos nos Estados Unidos e, por serem ricamente ilustrados e serem semelhantes aos papéis da Bolsa, receberam o nome popular de Bonds (Bônus, Ação). A própria empresa denominava 'bond' aos cupons, por entender que representavam o compromisso assumido com os passageiros. Aos poucos estes passaram a associar os cupons ao próprio Carril, denominando estes de Bondes.
} 
despir o jequismo"130. Era necessário reordenar a São Paulo do século XX, entretanto mantendo as tradições da elite conservadora. A cidade havia se reurbanizado dentro da ordem. Preparara-se para tornar-se uma "economia-mundo" braudeliana. Aumentou-se a fiscalização e a arrecadação da Prefeitura. Vários trechos da cidade foram arborizados e cuidava-se com esmero de jardins, mas não as pessoas.

Uma vez aparelhada, a capital atraiu gente de todos os pontos do país e do exterior. Dos 31.385 habitantes existentes em 1872, ela passou a contar com 47.697 habitantes em 1886 e com 64.934, em 1890. Entraria no novo século com 239.820 habitantes e concluiria o primeiro decanato com 375.324 habitantes. Quase a metade dessa população era constituída de imigrantes peninsulares, de onde o slogan que São Paulo recebera de "cidade de italianos.

O velho núcleo era considerado a polis, a cidade por excelência. Dizia-se vou à "cidade", e não vou ao centro. Era ali que se acumulavam as atividades comerciais e administrativas, uma série de igrejas e mosteiros, a Academia de Direito e outros estabelecimentos de ensino. No período republicano, o centro perdeu suas moradias. As casas térreas e os sobrados foram adaptados para escritórios, ou cederam espaço aos bares, cafés, armazéns, restaurantes, confeitarias, comércio de luxo, boticas, teatros, primeiros cinematógrafos, jornais, associações de fundos mútuos, etc. A cada dia, o centro recebia uma população flutuante intensa, a qual tinha o hábito de tomar as refeições em casa. Os fazendeiros de café se reuniam no Largo do Café onde se inteiravam das cotações do produto e fazia negócios. No antigo Triângulo, representado hoje, pelas ruas Direita, São Bento e $\mathrm{XV}$ de Novembro, se localizavam as lojas de moda e onde as senhoras elegantes faziam o footing, a pretexto do chá das cinco, tomados nas confeitarias ao som de música ao vivo. ${ }^{131}$

Numa cidade racionalizada, noutra delas uma capital higienizada, ainda uma última um novo campo planejado, tudo isso num país em princípio de revolução

\footnotetext{
${ }^{130}$ Ilustre morador de Higienópolis, presidente do Brasil entre 1995-2002, Fernando Henrique notabilizou-se por declarações elitistas como a de que o " brasileiro era um jeca tatu quando viajava ao exterior, encantava-se com o que via como um paspalho". Faltou-lhe o estofo da família Prado e o respeito aos cidadãos no cargo que exercia.

${ }^{131}$ HOMEM, Maria Cecília Naclério. Antônio da Silva Prado, prefeito da cidade de São Paulo: 1899-1910. Laboratório de Fundamentos da Arquitetura e do Urbanismo. FAU-USP. V Seminário de História da Cidade e do Urbanismo. "Cidades: temporalidades em confronto". Uma perspectiva comparada da história da cidade, do projeto urbanístico e da forma urbana. PUCSP. 1998
} 
urbano-industrial, era necessário controlar os negócios pelo direito, as massas pelo futebol e os setores médios e elite pelas artes. 


\section{CAPÍTULO 5 - REPÚBLICA VELHA E SEU OCASO ( 1914-1931)}

\subsection{O Direito}

Vem de longa tradição o Jusnaturalismo. Segundo tal doutrina, o Direito ( e a noção de Justiça) é algo universal e anterior a constituição das sociedades. Teve grande influência no direito brasileiro até o século XIX. Atualmente no Brasil predominam as doutrinas positivistas: Direito é norma. Trata-se da busca pelo justo formalizada na lei. Imperfeito e nem sempre correto, o Direito acompanharia a evolução da sociedade humana. Esquecem os cientistas jurídicos de que o Direito é socialmente construído. As normas representam interesses de classes. Dessa forma não são aptas a transformar a realidade social, mas sim de impor a força do Estado ( e este não é neutro) sobre todos, sejam eles súditos ou cidadãos. Se num determinado momento da História as leis bastam, o Direito se enrigece. Foi assim por todo o Império e boa parte da República Velha.

A batalha pela instituição de um Código de Direito Civil no Brasil perdurou por quase um século. O instrumento central de garantia jurídica do Direito Privado estava previsto na Constituição de 1824. Esta, em seu artigo 179, inciso XVIII, estabelecia que: "Organizar-se-á, quanto antes, um Código Civil e um Criminal, fundados nas sólidas bases da justiça e da equidade".

O principal fator dessa lentidão, mais do que os debates parlamentares insanos ou as disputas de egos entre juristas, foi de que a Lei de Terras ( Lei nº51 aprovada em 1850) respondia às necessidades da classe dominante de então: a aristocracia rural brasileira. No vácuo jurídico deixado pela Independência com o fim da validade das Ordenações Filipinas, ampliou-se rapidamente o apossamento das terras devolutas no país. Dizia a Lei de Terras em seu artigo primeiro, para vetar essa expansão que:

Art. $1^{o}$ Ficam prohibidas as acquisições de terras devolutas por outro titulo que não seja o de compra.

Além da exigência da compra e de seu devido título para a obtenção das terras, a Lei reconheceu as antigas sesmarias e as terras que possuíssem 'justo título' mesmo anteriores à Lei. Na prática regulamentou a propriedade da terra — principal instrumento e investimento no capital fixo num país agroexportador —, com os parâmetros do período colonial. 
No artigo 11, criava-se uma dificuldade e uma severa sanção que inviabilizavam qualquer tentativa de democratização no acesso á terra:

Art. 11. Os posseiros serão obrigados a tirar titulos dos terrenos que lhes ficarem pertencendo por effeito desta Lei, e sem elles não poderão hypothecar os mesmos terrenos, nem alienal-os por qualquer modo.

Esses titulos serão passados pelas Repartições provinciaes que o Governo designar, pagando-se $5 \$$ de direitos de Chancellaria pelo terreno que não exceder de um quadrado de 500 braças por lado, e outrotanto por cada igual quadrado que de mais contiver a posse; e além disso $4 \$$ de feitio, sem mais emolumentos ou sello.

Ou seja, os posseiros pobres jamais teriam dinheiro para reconhecer suas terras e dessa forma não lhes era permitido a negociação da mesma. E caso não respeitassem as novas regras do apossamento poderiam ser presos por 2 a 6 meses ( como garantia o $\operatorname{artigo} 2^{\circ}$ da Lei de Terras).

Garantido os interesses dos proprietários rurais, a regulamentação dos contratos, das obrigações, das posses e o direito à sucessão puderam esperar. Na área criminal o código entrou em vigor em 1830 por mãos do Visconde de Alcantara. A “paz social” de uma sociedade escravista e com uma burocracia estatal em formação não podiam esperar. Os tipos penais contra o Estado e administração pública tomaram 110 dos 312 artigos do Código de 1830.

Quanto ao direito civil, somente em 1855 o jurista baiano, Afonso Teixeira de Freitas, aceita a encomenda do Império. Primeiro ele faz uma compilação das leis e tratados civis em vigor e a apresenta dois anos depois. Terminada a Consolidação das Leis Civis, Teixeira de Freitas começa a redação do Código Civil encomendado. No final de 1859, influenciado pelos direitos romano e germânico, e propondo uma inovação: a unificação de todo o direito privado, com a incorporação de partes de Código Comercial aprovado em $1850,{ }^{132}$ o jurista do Império apresenta seu esboço final. Era um calhamaço de mais de 4.300 artigos, divididos em dois livros e cada um desses em 3 seções; regulamentando desde o nascimento com vida até a morte e sua sucessão. Sem a força devida para a aprovação, o contrato com Teixeira de Freitas foi encerrado anos depois. Porém, a obra jurídica não perdeu sua importância, em 1869 o jurista

\footnotetext{
${ }^{132}$ Cesare Vivante, jurista italiano entre o final do século XIX e início do XX, estabeleceu uma unificação do Direito Privado em Itália no ano de 1893. Aqui no Brasil, somente em 2003, com a entrada em vigor do Novo Código Civil, isto ocorreu. Teixeira de Freitas, em técnica jurídica, estava bem à frente de seu tempo.
} 
portenho Dalmácio Vélez Sarsfield o utilizou como base do Código Civil argentino. Este código só veio a perder sua vigência em 2015, com a aprovação do Novo Código Civil argentino.

Em 1871 surge uma nova tentativa de se estabelecer uma legislação civil, com o projeto de Visconde de Seabra, obra incompleta com pouco mais de 300 artigos, sendo que boa parte deles eram "inspirados" em Teixeira de Freitas. No ano seguinte, Nabuco de Araújo, conselheiro do Império e pai de Joaquim Nabuco, começa a redação de um novo projeto, este fica inacabado pela morte prematura do autor. O Império contratou Felício dos Santos e depois Antonio Coelho Rodrigues, mas os dois projetos encomendados foram negados.

Veio a República em 1889 e no ano seguinte, o então ministro da Justiça Campos Salles organiza uma comissão de juristas para a elaboração do Código, mas de novo não frutifica a obra. Coube a Epitácio Pessoa em 1898 ( ano do primeiro funding loan), como ministro da Justiça do agora presidente Campos Salles, convidar o jurista e ex-colega de faculdade Clóvis Beviláqua para a elaboração do Código Civil.

O projeto de Beviláqua é apresentado em 1899, apenas 8 meses após a encomenda governamental. Estava confeccionado com 1807 artigos ( com cerca de 230 inspirados em Teixeira de Freitas), entretanto só foi aprovado em 1916, depois de longos anos de discussão jurídica e parlamentar, a qual alterou alguns trechos do projeto original, com mais de 1700 emendas no Congresso ( entretanto apenas 186 foram aceitas). Finalmente o direito Privado estava codificado. A resistência ao projeto de Beviláqua foi do total desrespeito à simpatia com reservas, como vemos nesse parecer da Faculdade Livre do Rio de Janeiro:

O que vai ser analisado, porém, basta para por em alto relevo os graves defeitos desta última tentativa de codificação. Se ela não tem o estilo lapidar que caracteriza algumas das nossas leis orgânicas, não prima igualmente pela vernaculidade das expressões, nem pela elegância das construções gramaticais (....) Mas vale não ter Código algum do que um defeituoso (....) Por maiores e mais profundas que sejam as emendas formuladas durante o debate legislativo, elas não conseguirão corrigir os defeitos entranhados em todo o corpo do Projeto, e que só poderiam ser sanados com uma revisão total (....) $\mathrm{O}$ Projeto é mais uma tentativa a acrescentar às de Teixeira de Freitas, 
Nabuco, Felício dos Santos, Comissão de 1889 e Coelho Rodrigues. Não será a solução última do problema da Codificação ${ }^{133}$

Contudo, o inimigo mais feroz do Código de 1916 foi o político e eterno aspirante à presidência da República, Rui Barbosa. Em apenas 48 horas, o mestre do Encilhamento produziu um ataque frontal e desmerecedor do projeto do professor de Direito Internacional da Faculdade de Olinda. Numa das falas, diz Rui Barbosa:

Ai está por que, ao nosso ver, a sua escolha (de Beviláqua) para codificar as nossas leis civis, foi um rasgo do coração, não da cabeça. Com todas as suas prendas de jurisconsulto, lente e expositor, não reúne todos os atributos, entretanto, para essa missão, entre todas melindrosa. Falta-lhe ainda, a madureza de suas qualidades. Falta-lhe a consagração dos anos. Falta-lhe a evidência da autoridade. Falta-lhe um requisito primário, essencial, soberano para tais obras: a ciência da linguagem, a vernaculidade, a casta correção do escrever. Há nos seus livros, um desalinho, uma negligência, um desdém pela boa linguagem que lhe tira a concisão, lhes tolda a clareza, lhes entibia o vigor $^{134}$

Pontes de Miranda, talvez o maior civilista de nossa história, décadas depois afirmou que as críticas de Rui Barbosa “ (eram) são hoje trabalhos indispensáveis a quem procura estudar a língua portuguesa, mas sem nenhum interesse jurídico". Podemos afirmar que mesmo os estudiosos de nosso idioma sequer veem esse interesse atualmente. No parecer Rui Barbosa não apenas altera a linguagem, mas o sentido e a prerrogativa das garantias legais.

Ao analisar artigo por artigo do projeto da câmara, Rui critica e modifica a redação, fazendo uma espécie de novo código. No artigo $2^{\circ}$ do livro I que trata das pessoas, o projeto da câmara vinha com o seguinte texto: "Todo ser humano é capaz de direitos e obrigações na ordem civil", e Rui propunha alterá-lo para "Todo homem é capaz de direitos e obrigações na ordem civil". A alteração proposta é trocar a

\footnotetext{
${ }^{133}$ FACULDADE LIVRE DE DIREITO DO RIO DE JANEIRO. Parecer ao projeto de Código Civil. In: Código civil brasileiro: trabalhos relativos à sua elaboração. vol. 2. p, 59-61Rio de Janeiro: Imprensa nacional, 1918

${ }^{134}$ BARBOSA, Rui. A imprensa de 14 e 15 de março de 1898. Apud. MENESES E ARRUDA. Clovis Bevilaqua. p, 245, Extraído de: Discussões legislativas do Código Civil de 1916: Uma revisão historiográfica Gisele Mascarelli Salgado. Âmbito Jurídico. Disponível em:< http://www.ambito-juridico.com.br/site/index.php?n_link=revista_artigos_leitura\&artigo_id=10972\#_ftnref20> Acesso em: 31/07/2016
} 
expressão "ser humano" para a expressão "homem", e argumentava o senador que a palavra homem expressaria todo ser humano, dizendo: "Haverá ser humano, que não caiba na expressão geral da espécie homem?”. Barbosa cita para reforçar seu argumento alguns códigos civis que se utiliza da expressão homem. Essa alteração de Rui Barbosa foi acatada e o Código Civil foi impresso com a expressão "homem", para o desgosto de muitas feministas que vêem com muito mais simpatia a expressão "ser humano", pois ela não esconde a mulher, sob a expressão homem. O projeto do código tinha uma dimensão de valorização do gênero que não estava apenas no artigo 2 , mas modificava o status da mulher como inferior, trazendo alguns ganhos em especial no direito de família. Logo pode-se supor que essa expressão no art. 2, não fora colocada a toa. A alteração de Rui parecia para ele gramatical, pois não levava em conta essa necessidade de aclarar o novo status da mulher. As palavras expressam valores, idéias, pontos de vista, status social, poder, daquele que fala e sua alteração não é mera troca por sinônimos, é uma troca de valores. Assim, Rui interfere em um dispositivo e este pequeno ponto, como tantos outros, levarão a mudanças do projeto. Porém, Rui não pensa fazer uma alteração de direito, mas sim apenas gramatical sobre esse assunto, como destaca em seu Parecer Jurídico, escrito logo depois em $1905^{135}$

Em outra passagem, o original de Beviláqua diz:

“ Art. 1968. Aquelle que morre sem deixar testamento, succedem os seus descendentes."

Para Rui Barbosa e para a Lei n 3701 aprovada em 1916 o correto seria:

“ Art. 1.574. Morrendo a pessoa sem testamento, transmite-se a herança a seus herdeiros legítimos."

Juristas dirão que palavra 'herdeiros' é mais ampla do que 'descendentes'. Esta última seria espécie daquele gênero. Entre os sucessores poderíamos ter ascendentes do morto, o que inviabilizaria o artigo. Porém, o ponto essencial da norma é o denominado princípio da "saisine". Vindo do direito francês, a saisine garante que com a morte -

\footnotetext{
${ }^{135}$ Discussões legislativas do Código Civil de 1916: Uma revisão historiográfica. Gisele Mascarelli Salgado. Âmbito Jurídico. Disponível em:<http://www.ambito-juridico.com.br/site/index.php?n_link=revista_artigos_leitura\&artigo_id=10972\#_ftnref20> Acesso em: 31/07/2016
} 
seja ela testada ou intestada —, os bens serão transmitidos automaticamente ( e com custos irrisórios: 4\% de imposto) do "de cujus" para seus sucessores. Essa regra é essencial para o entendimento liberal brasileiro de que a propriedade é um direito natural do cidadão e o Estado não pode intervir. Interessante notar que no direito estadunidense, essa transmissão de bens é distinta. No caso de bens imóveis, os Estados Unidos impõe taxas de $46 \%$ para a sucessão de bens imóveis, o que na prática inviabiliza a mesma.

Se por um lado essa tarifa post mortem é suavizada a quase zero quando existe uma doação para fundações ou instituições educacionais ou de pesquisa, permitindo a sustentação do capitalismo norte-americano; por outro ela estimula o descendente a lutar sem apadrinhamento para acumular seu capital, confirmando a ideologia do self made man. Os tributaristas defendem ainda que esse modelo aproxima os laços familiares, afinal, segundo eles, os filhos só terão parte do quinhão hereditário se cuidaram devidamente dos pais. Por aqui, com a saisine e sua transmissão automática de bens e quase sem custos ( a taxa na sucessão varia de 3 a 6\%), desobriga os descendentes, pois de uma forma ou outra receberão a herança. Para o pensamento liberal ela criaria também uma ideologia da preguiça. Herdeiros que não precisarão lutar para adquirir suas riquezas.

O certo é que o Código Civil de 1916 que entrou em vigor no ano seguinte, ainda durante a Grande Guerra, tem como princípios basilares:

I) O contrato, com a proteção da suposta autonomia da vontade;

II) A família, como organização social essencial à base do sistema. Família monogâmica, heterossexual, com desconsideração inicial pelos filhos havidos fora do casamento. União apenas civil, mas com permissão para a tradição religiosa ser reconhecida com o "casamento para fins civis", mantendo a importância da Igreja Católica;

III) A posse e a propriedade, de direito natural, protegida ao extremo ( incluindo o desforço próprio e a legítima defesa na sua proteção) e não passível de perda ( a não ser em casos extremos como a usucapião). Posse e propriedade que explicam a relação jurídica entre as pessoas e as coisas.

Em resumo, segundo Judith Martins Costa, podemos dizer que o Código Civil de 1916:

...traduz, no seu conteúdo liberal no que diz respeito às manifestações de autonomia individuais, conservador no que concerne à questão 
social e às relações de família -, a antinomia verificada no tecido social entre a burguesia mercantil em ascensão e o estamento burocrático urbano, de um lado, e, por outro, o atraso o mais absolutamente rudimentar do campo, onde as relações de produção beiravam o modelo feudal.136

Antonio Carlos Wolkmer é mais radical em suas conclusões. Para ele, perdemos uma oportunidade histórica.

O Código Civil, em que pesem seus reconhecidos méritos de rigor metodológico, sistematização técnico-formal e avanços sobre a obsoleta legislação portuguesa anterior, era avesso a grandes inovações sociais que já se infiltravam na legislação dos países mais avançados do Ocidente, refletindo a mentalidade patriarcal, individualista, e machista de uma sociedade agrária preconceituosa, presa aos interesses dos grandes fazendeiros de café, dos proprietários de terra e de uma gananciosa burguesia mercantil. ${ }^{137}$

Todas as transformações políticas, sociais e econômicas pelas quais passavam o Brasil desde a segunda metade do século XIX, inviabilizavam o antigo sistema de leis. O novo direito, mesmo que em alguns momentos parecesse querer destruir os alicerces da elite rural e preparar o país para uma economia de mercado, como, por exemplo, com a ruptura do direito à propriedade proporcionada pela Abolição; em realidade, nada mais era do que uma nova regulamentação para velhos personagens e a garantia da exclusão para a grande maioria da população, seja ela recém-liberta, livre, urbana, rural, nacional ou imigrante. A sociedade da permanência garantida pela norma. Lênin observa fenômeno semelhante na formação do Capitalismo na Rússia:

Portanto, ainda sob o domínio da economia natural, com a primeira ampliação da autonomia dos camponeses dependentes, já parecerem os germes da sua desintegração. Esses germes, todavia, só podem se desenvolver com a forma seguinte de renda, a renda-dinheiro, que é uma simples modificação da forma de renda em produtos. O produtor

\footnotetext{
${ }^{136}$ MARTINS-COSTA, Judith. A boa-fé no direito privado: sistema e tópica no direito obrigacional. 2. tir. São Paulo: Revista dos Tribunais, 2000, p. 266

${ }^{137}$ WOLKMER, Antonio Carlos. História do direito no Brasil. Rio de Janeiro: Forense, 1999. In: ALABA, Felipe Camilo. Os 3 pilares do código civil de 1916
} 
imediato não entrega ao proprietário fundiário produtos, mas os preços desses produtos. A base dessa forma de renda é a mesma: o produtor imediato continua sendo o possuidor tradicional da terra, mas essa base caminha no sentido de sua decomposição. A renda-dinheiro supõe um desenvolvimento mais considerável do comércio, da indústria urbana, da produção mercantil em geral e da circulação monetária. A relação tradicional baseada no direito consuetudinário, entre o camponês dependente e o proprietário fundiário, se transforma em relação puramente monetária, fundada sobre um contrato. Isso conduz de uma parte, à expropriação do antigo campesinato e, de outra, ao resgate, pelo camponês, da sua terra e da sua liberdade. (grifo nosso) $)^{138}$

\subsection{O Futebol}

O escritor uruguaio Eduardo Galeano, autor do maior 'best seller' das esquerdas latinas com sua obra “ As veias abertas da América Latina” (1971), um belíssimo ensaio de história da Nossa América; também demonstrava sua paixão pelo futebol. Em crônica chegou a afirmar que "o gol é o orgasmo do futebol, e tanto este quanto àquele andam em falta na modernidade".

Na segunda parte desta tese vimos a formação do esporte bretão em São Paulo. Seu berço elitista e britânico. Um aparecer quase simultâneo à República — afinal Charles Muller nos apresenta o esporte em 1891. Período da industrialização do país, do fim da escravidão, bem como da atração de imigrantes para o Brasil. O ludopédio, como o quiseram denominar por aqui, se democratizou. Saiu dos clubes da elite, excludentes e racistas e foi para as ruas. As regras do bom comportamento esportivo, as etiquetas desnecessárias foram deixadas de lado pela criatividade e virtuosismo dos atletas do Cone Sul. O cadinho formado por negros, mulatos, mestiços, imigrantes ( especialmente italianos, portugueses e espanhóis) popularizou o futebol, fez nascer clubes de origem humilde, aproximou as massas da sua prática. Ou como narra Galeano:

Foi um processo incomparável. Como o tango, o futebol cresceu desde os subúrbios... Linda viagem havia feito o futebol: havia sido organizado nos colégios e universidades inglesas, na América do Sul alegrava a vida de gente que nunca havia pisado una escola. Nos

\footnotetext{
${ }^{138}$ LÊNIN. O capitalismo na Rússia. PP 114-115
} 
campos de Buenos Aires e de Montevidéu, nascia um estilo. Uma maneira própria de jogar o futebol, ia abrindo-se espaços, enquanto uma maneira própria de bailar se afirmava nos pátios de dança. Os bailarinos desenhavam contornos, floreando em um só tablado, e os futebolistas inventavam sua linguagem num minúsculo espaço onde a bola não era pisada e sim retida e possuída, como se os pés fossem mãos trançando o couro. Nos pés dos primeiros virtuosos criollos, nasceu o toque: a bola tocada como se fosse guitarra, fonte de música.

Simultaneamente, o futebol se tropicaliza no Rio de Janeiro e em São Paulo. Eram os pobres quem o enriquecia, enquanto lhes expropriavam. Este esporte estrangeiro se fazia brasileiro à medida que deixava de ser privilégio de poucos jovens acomodados, que o jogavam copiando europeus, e era fecundado pela energia criadora do povo que o descobria. Assim nascia o futebol mais bonito do mundo: um misto de jogo de cintura, ondulações do corpo e voos de pernas que vinham da capoeira, dança guerreira dos escravos negros, e dos artistas alegres das periferias das grandes cidades. ${ }^{139}$

Uruguai, Argentina e Brasil ( pela ordem de qualidade desportiva à época) assistiram nas décadas de 10 e 20 do século passado a uma explosão do número de praticantes e um crescimento vertiginoso do número de torcedores. Sevcenko ( 1992) dá conta do alvoroço que os jogos causavam na cidade de São Paulo, com um público crescente e que deixava de lado as tradições religiosas. Numa das duas partidas da final do Campeonato Paulista de 1919, entre o clube da elite Paulistano e o então clube popular, o Palestra Itália, o campo do Parque Antarctica era tomado por 40.000 pessoas ( número impressionante se imaginarmos que a capital paulista possuía pouco mais de 500.000 habitantes naquele ano, ou seja, quase $10 \%$ da cidade desceu à Barra Funda). O historiador alerta para o fato que na mesma data do 'match' era comemorado o Corpus Christi e as ruas da cidade estavam vazias de fiéis, apenas com padres e senhoras religiosas reclamando do descaso. Um novo ópio do povo talvez.

Como sempre, o grande capital rapidamente percebeu o potencial econômico dos esportes que nasciam e do poder de adestramento moral, além do respeito às autoridades e a hierarquia social que as atividades físicas permitiam:

\footnotetext{
${ }^{139}$ GALEANO, Eduardo. El futbol a sol y sombra y otros escritos. Ediciones P/L@. 2002. Tradução nossa
} 
Nem só guerra e festival - o novo surto desportivo era tido também como um fator inquestionável de incremento da produtividade econômica. (...) Não deveria escapar de fato a nenhum observador atento o quanto o adestramento físico $\mathrm{e}$ as suas necessárias implicações, em termos de hábitos de higiene, profilaxia, alimentação e regularização da vida cotidiana, acarretariam não só em aumento das aptidões físicas individuais, mas sobretudo numa consistente disciplina do comportamento e num estímulo extraordinário dos dispêndios de atividade, os quais causariam um impacto principalmente na dimensão das expressões coletivas. ${ }^{140}$

Harmonização da sociedade. Um respeito maior a hierarquia e ao comando. Hábitos saudáveis de comportamento. Em sociedades excludentes, com um batalhão de imigrantes pobres, ex-escravos e uma miríade de trabalhadores braçais sem mercado de trabalho, ou com um mercado sem estabilidade empregatícia nenhuma - e com uma organização política e sindical nascente, facilitando a exploração —; o desporto e, em especial o futebol eram um achado para a manutenção da ordem. Um circo romano mais refinado, de objetivos mais amplos e atingindo uma camada maior da população.

Desde o início das competições organizadas em ligas ( São Paulo organizou seu primeiro campeonato em 1902 e o Rio de Janeiro em 1906), o número de clubes, praticantes e torcedores foi crescendo. Outro detalhe, iniciou-se uma mística em torno dos grandes atletas. Os "craques" começam a receber prêmios em dinheiro, são reconhecidos pelas ruas, desfilam com seus carros caros e importados. O futebol permitia a inclusão e ascensão social de uns poucos.

Mas se, internamente, as décadas de 10 e 20 assistiram a popularização do futebol no Brasil e sua paulatina democratização, com o nascimento dos times de imigrantes e negros como o Corinthians em 1910 e o Palestra Itália quatro anos depois e o abandono das disputas pelos clubes da elite ${ }^{141}$; eram nossos vizinhos do Cone Sul que possuíam os times e seleções mais fortes, bem como os atletas de maior qualidade. $\mathrm{O}$ futebol na Argentina e Uruguai teve história parecida com a do Brasil. Origens na elite,

\footnotetext{
${ }^{140}$ SEVECENKO, Nicolau. Orfeu extático. Pág. 47

${ }^{141}$ O Club Atlético Paulistano, pertencente a família Prado e no qual jogavam membros da elite e imigrantes ricos ingleses, teve um rendimento impecável: entre 1903 e 1927 disputou 25 campeonatos e venceu 11. Mesmo tendo parado de disputar o Campeonato Paulista de Foot-Ball em 1928, ainda é o quinto maior vencedor. O São Paulo Atlhetic Club, time em que Charles Muller jogou e vencedor dos 3 primeiros campeonatos do Estado, também parou de participar dos torneios de futebol em 1912. Hoje destaca-se com seu time de rúgbi ( a versão inglesa do Futebol Americano).
} 
imigrantes ingleses e rápida popularização. E foi no menor dos 3 países que nasceu a maior hegemonia das duas primeiras décadas.

A Associón Uruguaya de Fútbol nasceu em 1898 e dois anos depois organizou o primeiro campeonato nacional uruguaio de futebol. Na final estavam o Central Uruguay Railway Cricket Club ( em 1914 mudou o nome para Club Atlético Peñarol) e o Club Nacional de Football. O Peñarol era o time dos ferroviários; o Nacional o time "criollo". Dividem 90\% dos títulos nacionais conquistados do início da liga uruguaia até os dias de hoje.

E coube a seleção "criolla" uruguaia assombrar a Europa nos anos 20. Convidados a disputar os Jogos Olímpicos de Paris, os uruguaios enfrentaram 40 dias de viagem e venceram o torneio com sobras. ${ }^{142}$ Quatro anos depois, em Antuérpia, os uruguaios repetem o ouro, mas dessa vez com muito mais dificuldade, afinal outra seleção sul-americana quase os derrotou, era a Argentina de Tarasconi e Ferreyra.

No bicampeonato europeu, um jogador negro uruguaio tornou-se o primeiro ídolo internacional. Era o filho de uma argentina com um ex-escravo foragido do Brasil, conhecido como Andrade. Andrade era um pai-de-santo que erradicou-se nos arredores de Salto (Uruguai) na década de 60 do século XIX. Em 1901 nasce José Leandro de Andrade, a futura "maravilha negra". Seu Andrade, o pai, estava com apenas 98 anos de idade. Desde pequeno, o rapaz alto, muito forte e habilidoso encantava pelo jogo vistoso. Em 1924, jogando pelo Nacional, Andrade foi para Paris. Estarreceu os comentaristas internacionais do esporte. Sobre José Leandro Andrade diziam ter:

...o tom exótico que deu sua cor escura e agilidade felina característica de sua raça, complementado por uma técnica rara e única de futebol que era incomparável. Surpreendeu a todos os que testemunharam o torneio, que o apelidaram de: “o maraveille noir" ( a maravilha negra). Toda uma multidão seguiu a celeste em Paris, vivendo conjuntamente o espanto do que eles mostravam em campo. Os sul-americanos de um país remoto, com uma maneira de jogar viva e eficaz, enlouqueceram os europeus. Com o "moreno" uruguaio provocando-os com malabarismos

\footnotetext{
${ }^{142} \mathrm{O}$ escrete uruguaio disputou 5 partidas em duas semanas. Foram 5 vitórias, 20 gols a favor ( com direito a uma goleada de 5 a 1 nos donos da casa) e apenas dois sofridos. Medalha de ouro e reconhecimento da FIFA como legítimo campeão mundial. Impressionados com o rendimento uruguaio, os dirigentes do órgão máximo do futebol, passaram a organizar um torneio próprio, que por uma série de entreveros só aconteceu 6 anos depois em Montevidéu.
} 
constantes e 'finesse' de uma gazela, a torcida o idolatrava como a 'vedette'sagrada. ${ }^{143}$

Andrade seguiu o roteiro usual da fama dos futebolistas. Em Paris foi tratado como lenda nos salões da cidade-luz: dançou toda uma noite com Josephine Baker e, virou amante de Sidonie Gabrielle Colette. Colette era escritora renomada na França. Anos depois receberá o Prêmio Nobel de Literatura. Um dos seus livros mais famosos era "Chéri”, a história de amor entre uma cortesã de 49 anos e um jovem alpinista social de 25 anos. A trama com interesses não tão éticos e com tal diferença de idade entre uma mulher e um homem chocara a Europa ( o contrário numa sociedade machista era natural). Curioso que Colette estava com 51 anos e Andrade 23. Nos mitos do futebol uruguaio dizem que Colette se apaixonou verdadeiramente pela Maravilha Negra, o que a fez escrever dois anos depois do 'affair' uma continuação do romance citado, denominada "Le fin du Chérie".

Andrade voltou para a Europa mais duas vezes: em 1925 numa turnê vitoriosa do Nacional e em 1928 para disputar as Olimpíadas. Ganhou um bom dinheiro jogando ( parou em 1938). Recebeu honrarias, virou ídolo. Ex-jogador, caiu no esquecimento. Abandonado por todos, viveu na miséria. Tornou-se alcoólatra e morador de rua. Faleceu miserável, dum misto de tuberculose e cirrose. Triste sina de centenas de futebolistas em nossa História. Do céu ao inferno em poucos anos.

A lógica capitalista não excluiu o futebol. Ao mesmo tempo em que cresciam o público e os adeptos da competição, o esporte deixou de ser um espetáculo de lazer para entreter as massas para se tornar uma atividade econômica lucrativa, com todas as desigualdades inerentes ao sistema. Garrincha era “ a alegria do povo”. Em verdade, todo o futebol é uma alegoria do povo. Em seu estudo publicado na Revista Econômica, João Manuel C.M. Santos ${ }^{144}$ nos demonstra a relação direta entre a expansão das ferrovias no território norte-americano e a formação das ligas de beisebol e futebol americano por lá. Os traçados que rapidamente cruzavam o país de ponta a ponta (passavam de 150mil km de malha viária em 1900), permitiram o deslocamento rápido e constante de pessoas, mercadorias, capitais e, claro, dos clubes e seus atletas. Por aqui,

\footnotetext{
${ }^{143}$ CARRIL, Juan A. Capelán. Nueve décadas de gloria. Montevideo: Estampas SRL Realizaciones, 1990. Citado por Os primórdios do futebol uruguaio: da English high school à celestial garra charrúa. Alvaro Vicente do Cabo em Anais do XXVI Simpósio Nacional de História - ANPUH • São Paulo, julho 2011.

${ }^{144}$ SANTOS, João Manuel Casquinha Malaia. O monopólio nos esportes: uma comparação da organização dos esportes comercializáveis nos estados unidos, na Inglaterra e no Brasil (1870-1920). Revista de História econômica \& História das empresas .v. 15 , n. 2 (2012)
} 
o máximo que se conseguiu organizar foram campeonatos Rio-São Paulo, estados interligados pela Central do Brasil. Farquhar talvez soubesse disso. Não do futebol em si, mas da necessidade que um país jovem e em processo de industrialização crescente, teria de interligar as regiões isoladas e mais do que isso, de fornecer toda uma gama de serviços públicos essenciais para uma população que ocupava as cidades. Ferrovias para o mercado nacional; bondes, eletricidade e água para as cidades.

O público crescia, as rendas das partidas traziam capitais. Atrair jogadores de qualidade, sem se importar com a tez da pele, ou com a origem social ou nacional era parte do negócio. Ou como diz Santos:

A necessidade por maiores arrecadações fazia com que os times deixassem de lado alguns dos pontos de seus estatutos visando à obtenção de melhores jogadores. Quanto maior a qualidade dos jogadores, maiores eram as possibilidades de se montar um bom time que fizesse bons jogos e pudesse disputar os melhores campeonatos em condições de se tornar o vencedor. Essa era a fórmula para atrair cada vez mais sócios e torcedores e aumentar as receitas do esporte que sustentava a maioria dos clubes. Os clubes passaram a aceitar sócios pelo seu potencial como bom jogador de futebol e, eram vários os convites para que um jogador trocasse um clube pelo outro. Os jornais mostravam indignação quanto a essa movimentação de jogadores pelos clubes... ${ }^{145}$

O profissionalismo chegara ao futebol coincidentemente com a industrialização e urbanização do país. Amadorismo e romantismo iam ficando no passado. Para Santos (2010):

A troca de jogadores e de empregos se dava abertamente. A situação se desenhava mais ou menos da seguinte maneira: um determinado jogador, com alta ' capacidade futebolística' e defendendo um clube pequeno da cidade, era constantemente aliciado por diretores dos grandes clubes no sentido de passar a defender esses clubes da cidade, ato conhecido como cavação. Ofereciam ao jogador trabalho em uma empresa de alguém ligado a este ou àquele clube, com salários razoáveis e condições de trabalho que dessem ao jogador

\footnotetext{
${ }^{145}$ SANTOS, João Manuel Casquinha Malaia. A revolução vascaína: a profissionalização do futebol e a inserção socioeconômica de negros e portugueses na cidade do Rio de Janeiro. FFLCH. História Econômica. Doutorado. 2010. p.135-136
} 
possibilidade de não perder treinos e jogos do novo clube. Não havia restrições às transferências dos footballers. ${ }^{146}$

A história se faz de permanências, contradições e transformações. O futebol, ao mesmo tempo em que colaborou para revolucionar as relações sociais, fez permanecer o racismo. Mário Filho em seu estudo inovador sobre o negro no futebol assim descrevia os clubes:

O Flamengo podia ter um preto no atletismo, no basquete, no waterpolo, no remo. Assistia-se a uma regata de longe, do pavilhão da praia de Botafogo, da amurada da Avenida Beira-Mar, de uma barca. Não se via direito o remador, via-se o barco, os remos. Os remadores, numa regata, viravam uns barcos, uns remos. Num match de futebol via-se o jogador em close-up. Batalha, Pena e Hélcio, Mamede, Seabra e Dino, Newton, Candiota, Nonô, Vadinho e Moderato. O Flamengo não podia ter nenhum preto em futebol. Em futebol precisava ser branco, tão branco como o Fluminense. Não era de admirar, portanto, que quando gente do Flamengo e do Fluminense se juntava para formar um escrete carioca, o escrete saísse todo branco, do quíper ao extrema-esquerda. ${ }^{147}$

Foi preciso um Vasco no Rio de Janeiro, um Corinthians em São Paulo, sem contar o time da baixada santista, o Santos Futebol Clube, para lentamente furar esse bloqueio segregacionista. Depois dos anos 20 passou a ser impossível um clube ganhar sem a presença de negros e imigrantes pobres como os italianos e espanhóis do Corinthians e Palmeiras em São Paulo e os portugueses do Vasco da Gama no Rio de Janeiro. Os clubes da elite carioca deixaram o remo para os brancos ( e o nome regatas na denominação); os de São Paulo abandonaram o futebol. Tais transformações sociais e culturais provocadas pelo futebol são descritas magistralmente por Sevcenko:

A intensidade e a pletora de estímulos, emoções, adestramentos, agilidades, impulsos, excitações, perspicácia, divertimento e gozo, além de transes profundos de expectativa, comunhão e euforia, se ofereciam como ganhos imediatos aos praticantes ou entusiastas dos esportes. Os poderes públicos podiam ou não manifestar intenções

\footnotetext{
${ }^{146}$ SANTOS, João Manuel Casquinha Malaia. A revolução vascaína: a profissionalização do futebol e a inserção socioeconômica de negros e portugueses na cidade do Rio de Janeiro. FFLCH. História Econômica. Doutorado. 2010. p.142

${ }^{147}$ FILHO, Mário. O negro no futebol brasileiro. Rio de Janeiro: Ed. Civilização Brasileira S.A., 1964.pág 29
} 
categóricas em relação aos efeitos sociais de disseminação das atividades atléticas, mas nelas os indivíduos e as comunidades encontrariam, por sua própria conta, um recurso de satisfação de muitas de suas carências e um meio de despertarem e disporem de porções negligenciadas, rejeitadas ou frustradas de suas energias. Fosse como simples exercício, como metáfora, como ritual ou celebração, o esporte tanto viria preencher o vazio da ruptura abrupta ocorrida na rotina cotidiana das comunidades, como traria o potencial de novas alternativas de adaptação e um novo repertório de atitudes congeniais a um mundo em imprevisível fermentação. ${ }^{148}$

Definida a alma do Capitalismo Industrial e da burguesia nascente com o Código Civil de 1916, estava também controlado o corpo com a profissionalização do futebol. Faltava para a identidade nacional o exercício de atingir a mente. A semana de arte moderna, inconscientemente, fez isso.

\subsection{As Artes}

"Éramos uns inconscientes" diria Mário de Andrade em referência de Alfredo Bosi $^{149}$. O pai de Macunaíma fazia a auto-crítica 20 anos depois da denominada “Semana de Arte Moderna de 1922”. Há consenso entre teóricos de que o início do movimento modernista foi 1917 com a exposição de Anita Malfatti e a crítica ácida e virulenta de Monteiro Lobato. O neto de fazendeiros do Vale do Paraíba, produtores de café, apegava-se às tradições. Em artigo escrito para o jornal Estado de São Paulo, ele assim descreveu a exposição:

Há duas espécies de artistas. Uma composta dos que vêem normalmente as coisas e em conseqüência disso fazem arte pura, guardando os eternos rirmos da vida, e adotados para a concretização das emoções estéticas, os processos clássicos dos grandes mestres. Quem trilha por esta senda, se tem gênio, é Praxíteles na Grécia, é Rafael na Itália, é Rembrandt na Holanda, é Rubens na Flandres, é Reynolds na Inglaterra, é Leubach na Alemanha, é Iorn na Suécia, é Rodin na França, é Zuloaga na Espanha. Se tem apenas talento vai engrossar a plêiade de satélites que gravitam em torno daqueles sóis

\footnotetext{
${ }^{148}$ SEVECENKO, Nicolau. Orfeu extático. Pág. 49

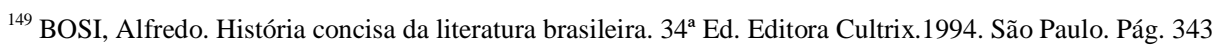


imorredouros. A outra espécie é formada pelos que vêem anormalmente a natureza, e interpretam-na à luz de teorias efêmeras, sob a sugestão estrábica de escolas rebeldes, surgidas cá e lá como furúnculos da cultura excessiva. São produtos de cansaço e do sadismo de todos os períodos de decadência: são frutos de fins de estação, bichados ao nascedouro. Estrelas cadentes, brilham um instante, as mais das vezes com a luz de escândalo, e somem-se logo nas trevas do esquecimento. ${ }^{150}$

Tempos depois, o pai do Jeca Tatu, vai usar da mesma virulência e desconhecimento técnico para tentar afastar Farquhar da exploração de siderúrgicas em Minas Gerais. Havia toda uma dificuldade em se entender a modernidade, seja ela no mundo das artes ou na economia. Porém, observa-se pontos em comum entre os alguns modernistas e seus críticos: nacionalismo exacerbado, visão autoritária da política (muitos expoentes da Semana de 22 apoiaram a ditadura getulista e outros cerraram fileiras no Partido Integralista) e uma arte produzida para as elites ( e financiada por estas, vide os patrocinadores do encontro no Teatro Municipal de São Paulo: a família Prado, os Pujol, os Armando Penteado, entre outros). Daí a "inconsciência" citada por Mário de Andrade. Uma arte que se propunha a construir novos padrões estéticos e que estivesse livre das amarras da tradição. Nas palavras de Maria Andrés Ribeiro:

O modernismo refere-se aos movimentos literários, artísticos e religiosos que ocorreram na Europa desde a segunda metade do século XIX, propondo o rompimento com a tradição passada e a construção de uma nova arte moderna e de uma moderna Igreja Católica. No campo artístico os movimentos modernistas do século XIX romantismo, impressionismo, pós-impressionismo - , considerando as suas especificidades, tiveram propostas comuns que podem ser sintetizadas nos seguintes princípios: o questionamento dos pressupostos básicos da arte acadêmica e da tradição artística oficial; a afirmação da autonomia da arte, liberdade de criação artística, originalidade da obra de arte, genialidade do artista; a busca de novas

${ }^{150}$ O Estado de S.Paulo. 20 de Dezembro de 1917. Paranoia ou mistificação? (A Propósito da Exposição Malfatti) 
soluções formais centradas na estrutura da obra de arte e nas estéticas pautadas pela teoria da arte pela arte. ${ }^{151}$

Não há dúvidas de que entre todos os artistas Modernistas, o artista que fazia a crítica política mais ácida contra a sociedade burguesa e em oposição ao Capitalismo era Oswald de Andrade. O rapaz de família rica, que estudou nas melhores escolas de São Paulo, inclusive cursando o renomado Largo do São Francisco ( uma fábrica de presidentes e políticos até o início dos anos 60); revoltou-se contra a realidade social, aderiu ao socialismo e ao partido comunista. Trajetória semelhante, mas em campos distintos, a de Caio Prado Jr. Criou revistas, elaborou o manifesto antropofágico, escreveu poemas e romances. Nos anos 30 produziu uma sólida dramaturgia. Talvez por sua filiação política é o menos elogiado pela crítica literária. Sua trilogia " A morte", "O homem e o cavalo" e "O rei da vela" só foram encenadas por José Celso Martinez nos anos 60. Peças que são um retrato da sociedade brasileira dos anos 20 e 30. Segundo os pesquisadores Santos \& Kothe:

A peça em estudo apresenta-se como um caleidoscópio temático, no qual o Autor exprime o "hic et nunc" de seu momento histórico de maneira objetiva. Dentro de um realismo critico, Oswald de Andrade apresenta-nos o decadentismo da aristocracia rural que, em desespero, alia-se à burguesia financeira e esta, por sua vez, ao capital estrangeiro, mostrando, assim, toda a engrenagem na qual se baseia $o$ esquema sócio-econômico do pais. Associado a esta problemática sócio-econômica, há todo um questionamento estético ao teatro, principalmente quanto à linguagem e aos recursos técnicos, colocando a peça (e também as duas outras da trilogia) como um marco na história da dramaturgia brasileira. ${ }^{152}$

O "Rei da Vela" é a mais panfletária das três. Apresenta ao menos três grandes temas: o panssexualismo ( presentes no segundo ato e o que menos interessa nesta análise); a expansão capitalista na economia brasileira e sua profunda dependência para com o capital estrangeiro e a aliança entre uma burguesia nascente e a aristocracia rural

\footnotetext{
${ }^{151}$ O modernismo brasileiro: arte e política Marília Andrés Ribeiro. P117. ArtCultura, Uberlândia, v. 9, n. 14, p. 115-125, jan.-jun. 2007

${ }^{152}$ Rita Santos \& Flávio Kothe. Questionamento estético e sócioeconômico em o rei da vela. Disponível em:<https://periodicos.ufsc.br/index.php/travessia/article/viewFile/18092/17009>. Acesso em 22 de agosto de 2016
} 
em decadência. Oswald de Andrade capta o espírito de época e compõe uma interessante alegoria da República Velha.

Peça em três atos, "O Rei da Vela" conta a história de dois agiotas: Abelardo e seu sócio, também denominado de Abelardo. Sua visão asquerosa e preconceituosa contra os clientes endividados é bem típica de nossas elites econômicas. Depois de muito humilhar e menosprezar seus clientes e, em certos momentos da peça, animalizálos, os Abelardos justificam a crueldade como sendo parte da lógica do capital. Mostra de forma critica também, qual o papel da polícia, o de lacaio do capital:

O CLIENTE (Desnorteado.) — Eu já paguei duas vezes...

ABELARDO I - Suma-se daqui! (Levanta-se.) Saia ou chamo a polícia. Ê só dar o sinal de crime neste aparelho. A polícia ainda existe...

O CLIENTE - Para defender os capitalistas! E os seus crimes! ABELARDO I — Para defender o meu dinheiro. Será executado hoje mesmo. (Toca a campainha.) Abelardo! Dê ordens para executá-lo! Rua! Vamos. Fuzile-o. É o sistema da casa. $^{153}$

Pouco depois, em linguagem didática e política ( antes da chegada dos textos de Brecht no Brasil), a peça diferencia o burguês proprietário do trabalhador que só possui sua mão de obra (e seus filhos):
ABELARDO II — Este está se queixando de barriga cheia. Não tem prole numerosa. Só uma filha... Família pequena! ABELARDO I - Não confunda, Seu Abelardo! Família é uma cousa distinta. Prole é de proletário. A família requer a propriedade e vice-versa. Quem não tem propriedades deve ter prole. Para trabalhar, os filhos são a fortuna do pobre... ${ }^{154}$

Como analisado anteriormente, temos o Direito para justificar e proteger o capital. Oswald aproveita para cutucar sua tão odiada faculdade, que em outro texto, este para o jornal "Hora do Povo", o qual ele era editor junto com Pagu, denominou o Largo do São Francisco de 'um cancro - a minar a sociedade paulista'. É Abelardo II

\footnotetext{
${ }^{153}$ ANDRADE, Oswald de Obras Completas VII TEATRO A morta Ato lírico em três quadros O rei da vela Peça em três atos O homem e o cavalo Espetáculo em nove quadros civilização brasileira.1973 pág. 67

${ }^{154}$ Ibid. Pág. 70
} 
quem fala: “Que importa? Dura lex, aprendi isso na Faculdade de Direito!” ( página 71 da obra citada)

Ainda no primeiro ato, Abelardo I dá conselhos para um industrial que faz as vezes de crítico. Neste trecho, Oswald ataca não só a burguesia refinada, mas a crítica literária que via com receios a obra politizada dele. Diz como combater o comunismo e defende que a Igreja católica não tem nenhum compromisso mais forte do que o dinheiro. Para Oswald de Andrade a burguesia morre sem Deus, porém nunca sem o capital:

ABELARDO I - Bem. Depois não venha fazer vales aqui, hein! Eu também sei ser fiel ao sistema da casa. Vá lá. Redija! Não, Tome nota, Olhe. É uma carta confidencial. A um tal Cristiano de Bensaúde. Industrial no Rio. Metido a escritor. Redija sem erros de português. O homem foi crítico literário e avançado, quando era pronto... Ele me escreveu propondo frente única contra os operários. Responda em tese (A secretária toma nota.), insinue que é melhor ele ser um puro policial. Manter vigilância rigorosa nas fábricas. Evitar a propaganda comunista. Denunciar e perseguir os agitadores. Prender. Esse negócio de escrever livros de sociologia com anjos é contraproducente. Ninguém mais crê. Fica ridículo para nós, industriais avançados. Diante dos americanos e dos ingleses. Olhe, diga isto. Que a burguesia morre sem Deus. Recusa a extrema-unção. Cite o exemplo do próprio Vaticano. Coisas concretas. A adesão política da igreja contra um bilhão e setecentos milhões de liras, o ensino religioso e a lei contra o divórcio. Toma lá, dá cá. Não vê que um alpinista como Pio XI põe anjos em negócios. ${ }^{155}$

O segundo ato mostra as tratativas entre Abelardo I e Heloísa de Lesbos. Oswald de Andrade faz uma interessante salada de referências nos nomes dos personagens. Pedro Abelardo e Heloísa personificam o amor impossível, primeiro carnal depois platônico. Viveram um romance proibido no início do século XII. A revelação do segredo levou a tragédia: o filósofo Abelardo é castrado, perde sua cátedra e torna-se padre. Heloísa perde sua honra, seu filho com Abelardo e entra para um convento. A troca de correspondências entre os antigos amantes é considerada um exercício de lógica, sensibilidade e de criação do "amor sob o ponto de vista feminino".

\footnotetext{
${ }^{155}$ ANDRADE, Oswald de. O rei da vela. Pág. 76
} 
O Abelardo I de Oswald é um agiota ( Vela do título refere-se a atividade de emprestar dinheiro a juros), um usurário que enxerga as pessoas como animais a lhe fornecer bens, capitais e riquezas. É a nova burguesia financeira que emerge com a expansão do capitalismo no Brasil. Heloísa é uma filha de aristocratas decadentes e endividados do café. O Lesbos do sobrenome remete ao panssexualismo da obra. Abelardo I seduz a sogra e a avó de Heloísa. Esta por sua vez tem irmã lésbica e irmão homossexual. Nada dos ideais cavalheirescos do século XII. Seguindo seu caráter didático, a peça fala abertamente da dependência econômica e financeira do Brasil e outros países pobres, em relação às potências industriais de então, especialmente os Estados Unidos e a Inglaterra. O personagem central entende a Divisão Internacional do Trabalho e não se revolta, afinal ele tem o capital, a terra e a nobreza decadente de Heloísa. Mesmo que em escala menor:

HELOÍSA - Eu li num jornal que devemos só à Inglaterra trezentos milhões de libras, mas só chegaram até aqui trinta milhões...

ABELARDO I - É provável! Mas compromisso é compromisso! Os países inferiores têm que trabalhar para os países superiores como os pobres trabalham para os ricos. Você acredita que New York teria aquelas babéis vivas de arranha-céus e as vinte mil pernas mais bonitas da terra se não se trabalhasse para Wall Street de Ribeirão Preto à Cingapura, de Manaus à Libéria? Eu sei que sou um simples feitor do capital estrangeiro. Um lacaio, se quiserem! Mas não me queixo. É por isso que possuo uma lancha, uma ilha e você... ${ }^{156}$

Abelardo I revela a Heloísa que o Capitalismo é monopolista. Não há espaços para a democratização no acesso à terra. Novos senhores formarão novos latifúndios. $\mathrm{O}$ café permanecerá como nossa grande riqueza:

HELOÍSA - Há dez anos... A saca de café a duzentos mil-réis! ABELARDO I - Estamos de fato num ponto crítico em que podem predominar, aparentemente e em número, as pequenas lavouras. Mas nunca como potência financeira. Dentro do capitalismo, a pequena propriedade seguirá o destino da ação isolada nas sociedades anônimas. O possuidor de uma é um mito econômico. Senhora minha noiva, a concentração do capital é um fenômeno que eu apalpo com as minhas mãos. Sob a lei da concorrência, os fortes comerão sempre os

\footnotetext{
${ }^{156}$ Ibid. Pág. 84
} 
fracos. Desse modo é que desde já os latifúndios paulistas se reconstituem sob novos proprietários. ${ }^{157}$

Abelardo I não se esquece da Grande Guerra nem da Revolução Russa de 1917. Era necessário oferecer empregos e divertimento ao povo ( e isso, como vimos anteriormente, o futebol fazia com muito sucesso). Profético, Oswald visualiza a Guerra Fria ao afirmar que o lucro do café deveria ser utilizado para a aquisição de armas. Para enfrentar tanto o inimigo interno, o movimento operário; quanto o externo, o socialismo:

\begin{abstract}
ABELARDO I - Contra qualquer pessoa! Qualquer guerra. Externa ou interna. É preciso dar emprego aos desocupados. Distrair o povo. E trocar café pelos armamentos que estão sobrando lá fora. As sobras da corrida armamentista. Você não vê logo? Ou então contra a Rússia! A Rússia está aporrinhando o mundo! $!^{158}$
\end{abstract}

A burguesia já foi inocente, foi até revolucionária...Nos bons tempos do romantismo, antes do cinema devassar o mundo (pág. 119). Fala contundente do protagonista que remete diretamente a Marx. A obras de Oswald de Andrade possuíam um fim. Tratavam-se de textos engajados. Traziam todo um compromisso com a transformação social da realidade injusta, desigual e excludente da sociedade brasileira. Ou como diria Sábato Magaldi:

Oswald não via diferenças entre uma linguagem de criação e uma linguagem de critica, entre uma obra esteticamente inovadora e uma obra de participação política e social que expressasse os erros de um mundo onde reina a injustiça e a dor ${ }^{159}$

O breve século XX teve um ciclo de obras literárias engajadas. O autor ou autora baseiam sua criação artística em seu credo político e ideológico. É um verdadeiro ato de fé. Uma pregação por meio da arte. A literatura engajada segundo Benoit Denis :

Recusando a validade da homologia entre inovação artística e revolução política estabelecida pela vanguarda, o escritor engajado entende participar plenamente e diretamente através de suas obras, no

\footnotetext{
${ }^{157}$ ANDRADE, Oswald de. O rei da vela. Pág. 85

${ }^{158}$ Ibid. Pág. 101

${ }^{159}$ MAGALDI, Sábato. Panorama do Teatro Brasileiro. São Paulo, Difusão Européia do Livro, 1962, p. 191.
} 
processo revolucionário (,,,) a literatura engajada não se pensa mais exatamente como um fim em si, mas como suscetível de tornar-se um meio a serviço de uma causa que ultrapassa largamente a literatura... 160

Fecha-se o ciclo da História Social da Primeira República brasileira. A alma do capitalismo estava organizada e codificada na proteção da propriedade, dos contratos e do liberalismo inseridos no Código Civil de Clóvis Beviláqua. O corpo estava domesticado com as atividades de lazer como o cinema, o teatro e, principalmente, com o espetáculo das massas que se tornou o futebol. Faltava controlar a mente. E os limites da Semana de Arte de 1922, bem como o ocaso e o ostracismo de obras de vigor e mudanças radicais como foi "O Rei da Vela" e de seu próprio autor, Oswald de Andrade; revelam as preferências de nossas elites: leituras afáveis e radionovelas. Nada de artistas purulentos e peças depravadas. Éramos um país de bons moços, senhoras casadouras, católico e de trabalhadores respeitadores da ordem e progresso.

\subsection{Breviário Político}

5.4.1.Wenceslau Braz ${ }^{161}$ (1914-1918)

No seu último pronunciamento oficial ao Congresso em maio de 1918, o presidente mineiro descreve a situação precária em que recebeu o país de Hermes da Fonseca. O marechal governara o país com mãos de ferro literalmente, afinal em boa parte do mandato instaurou-se o estado de sítio. Wenceslau prometera restabelecer a ordem, as finanças e a política do café-com-leite. O elenco de mazelas do quadriênio 1910-1914 é longo: estado de sítio de 8 meses; ressentimentos partidários profundos; o segundo funding loan; renda pública insuficiente; déficits mensais; vultosas dívidas flutuantes a pagar, seja em papel ou em ouro; tesouro sem recurso; crédito internacional abalado; desvalorização dos títulos públicos; desvalorização do câmbio; balança de

\footnotetext{
${ }^{160}$ DENIS, Benoit. Literatura e engajamento: de Pascal a Sartre. Edusc. Bauru. 2002. Pág. 25

${ }^{161}$ Pela regra que vigorou entre 1943 e dezembro de 2015, o nome do jurista brasileiro Ruy Barbosa (que sempre assinou assim, "Ruy", com "y") vinha sendo "atualizado" como "Rui Barbosa“. Da mesma forma, a grande escritora Rachel de Queiroz vinha tendo seu nome atualizado a "Raquel de Queirós", assim como Vinicius de Moraes havia sido transformado em "Vinícius de Morais", Euclydes da Cunha vinha sendo escrito "Euclides" e Oswaldo Cruz tinha quase virado "Osvaldo". Nem ex-presidentes haviam escapado da regra: Campos Salles virara Campos Sales, e Wenceslau Braz havia sido transformado num quase irreconhecível "Venceslau Brás“. A regra da atualização dos nomes próprios, porém, caducou em 31 de dezembro de 2015 , dia em que o Formulário Ortográfico de 1943 perdeu sua validade. Pelo novo Acordo Ortográfico da Língua Portuguesa, assinado em 2009 e obrigatório no Brasil e em Portugal a partir de 2016, não mais se atualizam as grafias: as grafias corretas, hoje, são, portanto, Rachel de Queiroz e Eça de Queiroz (e não *Queirós); Ruy Barbosa; Oswaldo Cruz; Vinicius de Moraes; Euclydes da Cunha; Wenceslau Braz.
} 
exportações e importações em crise; crise do comércio e da indústria; precarização do operariado.

Observadas com o distanciamento necessário, as críticas são verdadeiras. Mas como sempre há permanências históricas. No caso, é o cinismo de uma elite que parece não pertencer ao Brasil. Wenceslau Braz não só pertencia aos setores mais tradicionais da oligarquia que governava o Brasil desde 1889, como foi o vice-presidente da República dos 4 anos terríveis narrados por ele aos nobres congressistas. A conspiração em geral vem de dentro. As elites se acomodam em velhos estofados, trocando apenas o couro embrutecido pelo tempo.

O quadriênio de Braz ficou marcado pela morte de dois personagens centrais da República Velha: Pinheiro Machado e Oswaldo Cruz.

José Gomes Pinheiro Machado era natural de Cruz Alta no Rio Grande do Sul. Entrou para o exército, mas por problemas de saúde deu baixa. Formou-se em direito e passou a atuar na área e a organizar o movimento republicano em sua região. Tornou-se amigo de Julio de Castilhos e fundador do Partido Republicano Riograndense (PRR). Elegeu-se Senador pelo Rio Grande em 1890 e licenciou-se para combater ao lado de Julio de Castilhos na Revolução Federalista ( 1893-1894). Reelegeu-se senador por mais 4 vezes entre 1897 e 1915 . Nesse período foi vice-presidente do senado por quatro legislaturas. Era o cargo mais importante da República Velha, afinal o presidente da casa possuía um caráter simbólico, exercido pelo vice-presidente da República. A influência de Pinheiro Machado foi crescente. Controlava o legislativo e foi o braço direito de vários presidentes, entre eles Campos Salles e Nilo Peçanha. Se Ruy Barbosa foi a eterna oposição dentro do sistema; Pinheiro Machado era a promessa nunca cumprida. De forma trágica e ainda não totalmente esclarecida, Pinheiro Machado foi assassinado em setembro de 1915. Como seu legado temos que:

Pinheiro Machado participou decisivamente do cenário político brasileiro e, embora nunca tenha ocupado o cargo de ministro de Estado, foi o responsável pela indicação de vários ministros para diversas pastas. Além disso, dominou a máquina política de seu estado natal e projetou sua liderança pessoal sobre o Senado e a Câmara, formando um bloco majoritário muito coeso. Tinha ainda o controle da Comissão de Verificação de Poderes do Congresso Nacional, responsável pelos resultados eleitorais finais e pela diplomação dos eleitos. Através desse controle, podia negar uma cadeira no Congresso 
Nacional a um adversário, fazendo com que a comissão considerasse fraudulentos votos suficientes para dar a vitória a outro candidato. Dessa forma, alcançou um poder que talvez nenhum outro político tenha conseguido ao longo da Primeira República brasileira. E, como tal, elevou o Rio Grande do Sul a uma posição de eminência que o estado ainda não tivera na República e só durante a monarquia alcançara. ${ }^{162}$

\section{A Greve Geral de 1917}

Destaque-se também a maior greve geral de nossa história republicana: a de julho de 1917. Até os anos 80, a historiografia tradicional tratou o tema com conservadorismo e visão reacionária, ou com certa empatia, mas com um pretenso caráter "espontaneísta". Longe disso, a greve geral de 1917 foi fruto de vários anos de pregação doutrinária e de incitamento a luta pela ação direta. Experientes militantes anarquistas como Edgard Leunroth, Neno Vasco, Gigi Sorelli e Oreste Ristori e seus jornais como o Avanti, o Guerra Sociale, a Plebe e organizações de militantes como o Centro Libertário de São Paulo, o Centro Socialista de São Paulo, A Liga Feminina da Móoca, entre outros. Apesar das distinções de programa e de entendimento sobre a realidade social do país, os diversos grupos formados por jornalistas libertários, imigrantes politizados, mulheres feministas e operários uniam seus ideais e passaram a lutar por dois pontos em comum: a ação direta por meio de Greve Geral e a solidariedade entre eles:

A deflagração da Greve Geral de 1917 se tornou possível graças ao trabalho de propaganda e ação libertária desenvolvida pelos anarquistas, desde a virada do século, junto ao operariado paulistano. No primeiro semestre de 1917, militantes anarco-comunistas e anarquistas-sindicalistas, as duas correntes mais expressivas do movimento libertário de São Paulo, através de um esforço coletivo deixaram as rusgas e as diferenças de lado e uniram suas forças para despertar nos trabalhadores o sentimento de revolta contra as precárias condições de vida e de trabalho e a vontade de lutar por uma vida com dignidade. ${ }^{163}$

\footnotetext{
${ }^{162}$ SILVA, Izabel Pimentel. Pinheiro Machado. Verbete. CP DOC. FGV. Disponível em: $<$ http://cpdoc.fgv.br/sites/default/files/verbetes/primeira-republica/MACHADO,\%20Pinheiro.pdf > . Acessado em 01/09/2016. ${ }^{163}$ LOPREATO, Cristina da Silva Roquette. O espírito da revolta. Tese de Doutorado defendida no Departamento de História do IFCH. Unicamp - SP. 1996. Orientador: Edgar S.de Decca. Pág. 47
} 
Leunroth passou boa parte do primeiro semestre de 1917 fazendo comícios e incitando a conscientização da classe operária. Os jornais anarquistas circulavam pelas fábricas. Denunciavam a exploração excessiva da classe operária. Defendiam entre outras bandeiras: o fim do trabalho para menores de 14 anos; a proibição de trabalho noturno para mulheres e menores de 18 anos; a redução da jornada para 8 horas; reajustes reais de salários, corroídos pelo excessivo endividamento do estado brasileiro e pela inflação crescente. Em 9 de julho, as tropas do presidente Altino Arantes avançam sobre os trabalhadores que protestavam em frente à tecelagem Mariângela. $\mathrm{O}$ operário e imigrante espanhol José Ineguez Martinez foi atingido e não resistiu aos ferimentos, falecendo nas ruas da capital paulista.

O cortejo fúnebre no dia seguinte foi o estopim do movimento. Nos dias seguintes várias fábricas aderiam à Greve. O comércio e algumas atividades de serviços também pararam. As lideranças anarquistas instituíram o Comitê de Defesa Proletária. No dia 13 de Junho, cerca de 90 mil trabalhadores estavam de braços cruzados em São Paulo. A capital estava sem água, pão, luz e transportes. A maioria das fábricas estava de portas cerradas. O movimento se espalhara pelo Rio de Janeiro e Bahia. No interior, fábricas de Campinas, Jundiaí e Sorocaba também aderiram ao movimento. Santos enfrentava o boicote dos estivadores.

O dia 14 de julho, utilizado como a data para a negociação entre representantes do governo paulista e empresários foi uma coincidência histórica, era a mesma data da Tomada da Bastilha. Algumas das exigências das lideranças operárias anarquistas foram atendidas. Tudo caminhava para a pacificação, mas nos dias 15 e 16 veio a tradicional repressão. Navios torpedeiros em Santos, policiais aprisionando as lideranças. A questão social era sempre uma questão de polícia. Nos anos seguintes vários imigrantes politizados foram deportados. Os jornais anarquistas foram empastelados. As indústrias criaram seu sindicato, o Centro das Indústrias do Estado de São Paulo (CIESP). Listas negras com nomes dos operários militantes correram pelas fábricas. Ficou a lição da união das esquerdas e a estratégia vitoriosa de luta, descritas por Lopreato:

Apesar das diferenças, as duas correntes defendiam a mesma estratégia de luta para a emancipação dos trabalhadores, a ação direta, isto é a iniciativa de cada um reagir por si mesmo contra as mazelas da sociedade burguesa. A eficácia da ação individual, no entanto, só se revela na luta coletiva. Daí a outra estratégia, a solidariedade entre os 
trabalhadores. E tendo como estratégia exemplar dessa luta a Greve Geral. ${ }^{164}$

\section{Um país em Guerra}

Outro grande problema do governo Wenceslau Braz foi a Grande Guerra (19141918). As relações econômicas do Brasil com a Alemanha eram antigas e de valor considerável. Mas a sequência de fatos de 1917 obrigou o governo brasileiro a declarar guerra aos germanos. Guerra para um país endividado, com forças armadas despreparadas e lideradas por um governo pífio internacionalmente não poderia terminar bem.

Era 3 de Abril de 1917. O Príncipe George Lvov era o primeiro ministro da Rússia há duas semanas, após a abdicação de Nicolau II. Um submarino alemão colocou a pique o navio Paraná. A lentidão de Wenceslau Braz e da cúpula política brasileira impressionava. Só em fins daquele mês o governo anunciava sua neutralidade na Grande Guerra. Pressionado por sua ascendência germânica, o ministro chefe do Itamaraty, Lauro Müller, renuncia e assume Nilo Peçanha. No dia 20 de maio o Tijuca é torpedeado por alemães na França. Alexander Kerensky, o advogado do Partido Socialista era o novo premiê russo há um mês. Lênin já anunciara suas "Teses de Abril". Em 2 de Junho, o governo Braz anuncia medidas drásticas: o Brasil sai da neutralidade ( mas não declara guerra à Alemanha) e se arvora ao direito de confiscar navios inimigos em caso de novo ataque.

Às portas da Revolução de Outubro na Rússia, dois torpedos teutônicos atingem navios brasileiros: o Lapa e Macau. Finalmente, em 26 de Outubro de 1917, Wenceslau Braz declara guerra à Alemanha. Lênin tomava o poder na Revolução de Outubro e logo depois negociava a retirada da Rússia do conflito no Tratado de Brest-Litovsky. As autoridades brasileiras se reuniram em Paris por duas semanas, enquanto isso os alemães afundavam o Acaré e o Guaíba.

Finalmente, em início de dezembro, o governo brasileiro confisca 30 navios alemães e os entrega ao governo francês. Nosso primeiro ato de guerra ocorria paralelamente a organização do poderoso Exército Vermelho por Leon Trotsky, as voltas com a contra-revolução do exército branco. A lentidão de nossa política era tamanha que somente em junho de 1918 foi autorizada a primeira missão oficial

\footnotetext{
${ }^{164}$ LOPREATO, Cristina da Silva Roquette. O espírito da revolta. Tese de Doutorado defendida no Departamento de História do IFCH. Unicamp - SP. 1996. Orientador: Edgar S.de Decca. Pág. 48
} 
brasileira $^{165}$ : o general Napoleão Fellipe Aché detinha as ordens e o coronel-médico Nabuco de Gouveia chefiou a Missão Médico Militar Brasileira com 131 homens, entre pessoal da saúde, apoio e administrativo. Partiram em 28 de agosto, causaram comoção nacional com a morte de 5 tripulantes de gripe espanhola e aportaram em França nos fins de Setembro. Montaram inclusive um pequeno "hospital brasileiro".

Todavia os primeiros soldados mesmo foram 10 oficiais aviadores da marinha e um do exército liderados pelo capitão de corveta Protógenes Guimarães e incorporados pela Royal Air Force britânica. Além disso, em 9 de fevereiro de 1918 a Marinha decide enviar embarcações para a batalha na Europa ( 2 cruzadores, 5 contratorpedeiros, 1 tender e 1 belmont) e cerca de 1500 soldados chefiados por Pedro Max de Frontin. Era o Departamento Nacional de Operações de Guerra. Como sempre, entre a publicação do decreto presidencial e a partida da missão correu um longo prazo. Somente em $1^{\circ}$ de agosto de 1918 as embarcações saíram do Brasil. Nessa época Rodrigues Alves já era o primeiro presidente reeleito de nossa história e Lênin iniciava suas reformas econômicas e o regime de partido único. Passados oito dias de viagem, a missão militar aporta no continente africano. Os soldados realizam exercícios de guerra em terra e no dia 23 de agosto partem para Dacar, onde descem três dias depois. Nesse curto trajeto, o navio Rio Grande do Norte atinge um submarino alemão. Nossa primeira batalha.

A tropa estava em euforia. Mas as vésperas da Independência brasileira um imprevisto: cerca de 70 soldados quedavam doentes, era a terrível e quase sempre fatal gripe espanhola. As tropas ficaram em quarentena até a pronta recuperação. Tristemente, 156 soldados brasileiros perderam a vida, assolados pela gripe. Em 3 de Novembro de 1918 as embarcações deixam Dacar para finalmente enfrentar os inimigos alemães. Concluem a travessia em direção a Gibraltar em 10 de Novembro. Apresentam-se ao vice-almirante Heathcoat Grant e a partir daí passam a seguir suas ordens. Na manhã seguinte, na floresta de Compiègne na França, é assinado o armistício: terminava a Primeira Guerra Mundial.

\subsubsection{Delfim Moreira (1918-1919)}

Rodrigues Alves foi reeleito em novembro de 1918. Seria a única vez que isto aconteceria em toda a República Velha. Semi-morto, sequer assumiu. Incumbência esta que coube a seu vice, Delfim Moreira, que apesar de 20 anos mais jovem estava com

\footnotetext{
${ }^{165}$ Os dados citados aqui foram extraídos da obra de: DARÓZ, Carlos. O Brasil na primeira guerra mundial: a longa travessia. São Paulo. Editora Contexto. 2016
} 
arteriosclerose. Afora isso, seus colegas do café-com-leite já o consideravam de uma parvalhice sem tamanho. O senador gaúcho Soares dos Santos comentou a Borges de Medeiros que o vice-presidente possuía uma "inteligência abaixo do medíocre e, (era) tão incompetente quanto nulo". Gostava mesmo era de pescar no sítio em Itajubá.

Delfim convoca novas eleições em março de 1919. A oligarquia apresenta Epitácio Pessoa, a "oposição” vem do eterno candidato Rui Barbosa. Epitácio estava em Versalhes, era o chefe da delegação brasileira que negociava o Tratado de Paz celebrado após a Grande Guerra. Para o Brasil interessava o café. A recuperação de seu preço, a devolução das sacas confiscadas pela França, a manutenção da frota naval de transporte utilizada para o conflito europeu. Éramos um gigante diplomático nas negociações.

Epitácio Pessoa vence com $65 \%$ dos votos; Rui fica indignado. Alegava que o paraibano possuía um impedimento para assumir o cargo. O causo era o seguinte: Epitácio Pessoa era um "prodígio" dos coronéis. Aos 18 anos, primeiroanista de Direito, é nomeado Promotor de Justiça numa cidade do interior da Paraíba. Depois virou secretário de estado, deputado, senador, ministro e em 1902 foi indicado por Campos Salles para assumir como ministro do Supremo Tribunal Federal (STF) ${ }^{166}$. Licenciou-se para se tornar chefe dos Procuradores da República em 1907. Reassumiu a Corte Suprema 5 anos depois, para logo depois aposentar-se em 1912, aos 47 anos. Aposentadoria por invalidez permanente e com vencimentos integrais. Incapacitado, abriu uma banca de advogados especializada em processar a Fazenda Pública. E fez isso por 6 anos. Em julho de 1919 ele assume a Presidência. Na defesa contra as acusações de imoralidade e impedimento — feitas por Rui Barbosa —, alegou que a invalidez permanente era para as funções jurídicas e não executivas. Quanto ao fato de mesmo estando inválido continuar atuando como advogado e, além disso, o de receber uma gorda aposentadoria do Estado para processar com frequência o Erário Público, Epitácio dizia que não havia nenhum impedimento jurídico para tal exercício. Rui perdeu mais —uma. A República Velha preservava seus valores.

\footnotetext{
${ }^{166}$ As Ordenações Filipinas instituíram um Tribunal da Relação em Salvador. Tratava-se de um tribunal de segunda instância que recebia os recursos processuais. A Relação de Salvador começou a funcionar em 1609 e fechou em 1626. D.João IV a restaurou 26 anos depois. Foi a única do país até 1751, quando surgiu a Relação do Rio de Janeiro. Como o Rio tornou-se a capital do Brasil, em 1808 D.João VI elevou a Relação da cidade à condição de Casa de Suplicação do Brasil. Uma verdadeira Corte Suprema. Por Decreto, após a independência, a Suplicação passou a ter 17 ministros de amplo conhecimento jurídico e passou a denominar-se Supremo Tribunal de Justiça. Carregou esse nome entre 1829 e 1890 . A denominação Supremo Tribunal Federal foi adotada na Constituição Provisória publicada com o Decreto n. ${ }^{\circ}$ 510, de 22 de junho de 1890, e repetiu-se no Decreto n. ${ }^{\circ} 848$, de 11 de outubro do mesmo ano, que organizou a Justiça Federal. Desde então a forma de sua constituição é a mesma: um jurista é indicado pelo Presidente da República e o Senado o aprova ou reprova o seu nome ( o que nunca ocorreu). O cidadão escolhido torna-se ministro do STF.
} 


\subsubsection{Epitacio Pessôa ( 1919-1922)}

\section{Um apêndice do Foot-ball}

Lima Barreto dá como fonte o Correio da Manhã. Mário Filho, por sua vez, cita Lima Barreto. Eduardo Galeano referenda seus argumentos no irmão de Nelson Rodrigues. Segundo os três intelectuais, o oligarca presidente Epitácio Pessoa - exministro aposentado por invalidez permanente —, não gostava muito de povo. Teria aprovado um decreto proibindo a presença de jogadores negros na liga de futebol e na seleção brasileira. Valeu entre 1921 e 1922, com amplo apoio da Confederação Brasileira do Desporto (CBD), a antecessora da entidade privada atual que organiza o futebol no país, a Confederação Brasileira de Futebol (CBF).

Na mesma época em que Gandhi iniciava sua luta pelos excluídos párias e defendia a desobediência civil e a não violência na Índia. Dois anos depois do nascimento de Nelson Mandela na África do Sul, nosso presidente não deixava nada a dever à segregação racial existente no mundo. Há ardorosos defensores da tese de que o decreto nunca existiu, porém Noleto o confirma:

1920 - O Presidente Epitacio cria a Universidade do Estado do Rio de Janeiro. Por ordem sua, fica proibida a participação de jogadores negros no selecionado brasileiro de futebol. Monteiro Lobato publica Negrinha. ${ }^{167}$

Afora isso, o fato da Seleção de 1921 não ter levado nenhum negro em sua composição para a disputa do Campeonato Sul-americano na Argentina. Excluindo também o maior jogador do país, o mulato Artur Friedenrich. Apelidada de "seleção de marfim", o Brasil terminou o torneio com apenas uma vitória. No ano seguinte, a CBD aprova um regimento interno que "suaviza" o racismo imposto por Epitácio Pessoa: apenas jogadores alfabetizados poderiam participar, ou seja, a maioria absoluta dos negros e mulatos estavam excluídos.

Como o campeonato seria em homenagem ao centenário da Independência do Brasil, ele foi realizado no estádio das Laranjeiras no Rio (entre setembro e outubro de 1922). Preocupado com a derrota dentro de casa, afinal o futebol já era tratado por parte

\footnotetext{
167 NOLETO, Mauro Almeida. Memória jurisprudencial-ministro Epitacio Pessôa. Gráfica do STF. Brasilia. 2009. Pág. 36. Curiosidade notar que o romance de Lobato, tão criticado por seu racismo atualmente, foi publicado no mesmo ano do decreto nefasto.
} 
da imprensa como a "pátria de chuteiras"168, a CBD permitiu a presença de Neco ( o Neguinho do Corinthians), o imigrante italiano Heitor e por alguns jogos, o mulato Friedenreich. Era o segundo título brasileiro. Epitácio se despedia do poder duas semanas depois. Negro no Brasil, só o café.

\section{Tenentismo}

Nossa história é repleta de líderes políticos que tem a grandeza de um pirulito de criança. E tão infantis quanto, aqueles se dão a escrever cartinhas. Embora a maioria dos historiadores neguem a autenticidade da "carta" de Artur Bernardes em 1921, ela causou estragos. 'A carta não podia ser minha' diria o futuro presidente do Brasil, afinal ele não cruzaria o "t" na assinatura como no original mostrado pelo Correio da Manhã. Verídica ou não ela reproduzia o pensamento anti-militarista da oligarquia no poder e por isso causou tamanha celeuma no alto e baixo oficialato brasileiro. $\mathrm{O}$ candidato Bernardes teria feito críticas severas ao Exército brasileiro e humilhado o ex-presidente Hermes da Fonseca. Estouram alguns levantes populares, o maior deles é o do Forte de Copacabana em julho de 1922.Os bombardeios ao forte e os combates em rua levaram a quase 300 mortes. Na avenida Atlântica nasceu o mito dos 18 que marcharam em direção à morte. Hélio Silva contabiliza 28 pessoas mais o civil que se incorporou aos ideais dos tenentes para morrer no asfalto quente de Copacabana.

Posteriormente a História denominará o movimento de Tenentismo. Teve forte atuação na política brasileira entre 1922 e 1934. Suas características essenciais são:

I. Um descontentamento generalizado com as oligarquias rurais que comandavam o país há 34 anos;

II. O discurso moralista de combate à corrupção e as fraudes eleitorais;

III. Desafio ao poder regional dos coronéis;

IV. Nacionalismo exacerbado;

V. Apesar do nome "tenente", havia representantes desde a cúpula militar como Eduardo Gomes e Siqueira Campos, passando pelo médio oficialato como Luis Carlos Prestes, até os tenentes propriamente ditos;

\footnotetext{
${ }^{168}$ Lima Barreto refere-se em suas crônicas ao tratamento dado por parte das lideranças políticas, aos intelectuais da oficialidade e donos de jornais. Assim descreve os mesmos: “...É que para gente desse calibre, a grandeza de um paiz nao se vende pelo desenvolvimento das artes, da sciencia e das lettras. O padrão do seu progresso é o grosseiro - football - e o xadrez dos ociosos ricos e profissionais. (...) O Brazil ao acreditar em semelhante pessoal ficará celebre no mundo, desde que ganhe campeonatos internacionaes dessas futilidades todas. E, sendo assim, em breve apparecerá um Camóes ou um Homero para rimar uma epopéa em louvor desses heróes esforçados, que nada fizeram para o beneficio commum, mas que são glorias do Brasil." Revista Careta. 7 de Janeiro de 1922. Número 0707. Ano XIII. Pág. 19
} 
VI. Uma oposição entre os interesses da burguesia urbana em formação e uma rejeição aos setores agraristas e atrasados da sociedade.

Muitos estudos recentes desconsideram esse último aspecto. Acreditam ser o Tenentismo uma acomodação dos novos setores médios e da burguesia nascente com os interesses do capital agrário tradicional. Esquecem da luta de classes, dos interesses conflitantes e muitas das vezes confundem suas escolhas pessoais futuras com a interpretação do passado histórico. Talvez querendo justificar as posições tomadas.

Epitacio Pessôa teve um governo de recuperação econômica. Terminada a Grande Guerra, os preços internacionais do café tiveram acréscimo. Além disso, nas negociações de Versalhes, o Brasil garantiu a posse dos navios mercantes alemães, bem como a reabertura dos portos germânicos para nosso produto principal. No Tratado pósGuerra recuperamos também o café confiscado pela 'Entente' para reservas de Guerra. Outra vez, o governo brasileiro alimenta o mercado interno com emissão de moedas.

Na questão política, a sucessão foi complicada. Nilo Peçanha formou a Reação Republicana para enfrentar o razoavelmente rachado café-com-leite. Como sempre, as eleições foram fraudadas e a pouca participação da população (por uma série de impedimentos legais ou coronelísticos) levou a vitória do candidato oficial, Arthur Bernardes.

Os últimos 8 meses de mandato foram debaixo de estado de sítio. As greves operárias se sucederam de 1917 a 1922. A Revolução Russa começava a influenciar a luta dos trabalhadores no Brasil e no mundo. As potências capitalistas sabiam disso, pois o Tratado de Versalhes, arquitetado para reestabelecer a paz na Europa, instituiu a Organização Internacional do Trabalho (OIT) em 1919. Partia do pressuposto de que a paz mundial tem relação direta com a justiça social.

A OIT em sua fundação adotou seis convenções: a limitação da jornada de trabalho a 8 diárias e 48 semanais; à proteção à maternidade; à luta contra o desemprego; à definição da idade mínima de 14 anos para o trabalho na indústria e a proibição do trabalho noturno de mulheres e menores de 18 anos. O Brasil foi signatário da Convenção, mas só começou a cumpri-la décadas depois. No início de 1922 nascia no Rio de Janeiro o Partido Comunista Brasileiro, mas sua filiação ao Komintern se daria dois anos após. Em São Paulo acontecia a Semana de Arte Moderna. Emergia uma nova sociedade, sem o gosto forte do café. 


\subsubsection{Arthur Bernardes ( 1922-1926)}

O mais autoritário dos presidentes da República Velha não foi um militar. Bernardes governou quatro anos debaixo de uma repressão brutal. O Estado de sítio virou regra. A censura era permanente. Estimulou a formação de listas negras nas empresas. Instituiu o Departamento Estadual de Ordem Política e Social (DEOPS). A prometida anistia aos revoltosos de 1922 nunca foi concedida. Na Revolução Paulista de 1924, a cidade de São Paulo só não foi barbaramente bombardeada por causa da retirada estratégica de Isidoro Dias Lopes - mesmo assim, quase duzentos projéteis de canhão atingiram a capital paulista.

Talvez entre seus feitos ditatoriais, o maior esteja no campo de concentração de Clevelândia do Norte $(\mathrm{AP})^{169}$. A prisão foi criada em meio a uma região inóspita. Calor intenso, chuvas quase diárias, cercada por rio caudaloso, o Oiapoque ( antigo ponto extremo norte do Brasil) e uma floresta equatorial fechada. Tomada por mosquitos, insetos de todos os tipos, aranhas, escorpiões. Era o Inferno Verde, a Sibéria Brasileira. A aparência da prisão lembra a rede de campos de Auschwitz, no sul da Polônia, construída pelos nazistas alemães. Prédios retangulares e isolados um do outro, paredes quase sem janelas, com centros internos vazios. Espaços externos exíguos e protegidos por imensas cercas de arame farpado de 3,5 metros de altura.

Segundo os poucos sobreviventes do cárcere que existiu entre 1924 e 1926, a natureza e a arquitetura eram as partes mais agradáveis do ambiente. Internamente, Clevelândia era uma verdadeira masmorra. Os presos trabalhavam em período integral e sem descanso. Recebiam rações alimentares insuficientes, apanhavam com frequência dos carcereiros. Não havia lazer. Escravos sem dúvida alguma. No roteiro de terror havia até um Mengele tropical, o doutor Joaquim Paulo. Quem entrava doente na enfermaria, saía cadáver.

Os hóspedes da prisão de Clevelândia eram em sua maioria os arruaceiros e bandidos de sempre: líderes anarquistas, imigrantes que participaram das lutas sociais depois de 1917, sindicalistas e claro, uns poucos assassinos, rufiões e ladrões levados ao Oiapoque para perturbar e desagregar os criminosos políticos. Nos pouco mais de dois

\footnotetext{
${ }^{169}$ Groover Cleveland elegeu-se presidente americano em 1884. A situação econômica do país era complicada. Teve problemas também com a questão indígena. Cleveland ganhou as manchetes com o primeiro e único casamento na Casa Branca até hoje. Não só por ser na Casa Branca, mas por ter sido testamenteiro do pai de sua noiva, Frances Folsom ( 30 anos mais nova do que ele) e preceptor desta. Tentou a reeleição em 1888 e foi derrotado. Em 1892 volta à presidência, sendo o único chefe do executivo americano eleito para dois mandatos não sucessivos. Logo após o reconhecimento do Amapá como território brasileiro em início do século XX e para homenagear a participação norte-americana nas disputas diplomáticas, nasceu a vila de Clevelândia, as margens do rio Oiapoque, antigo ponto extremo norte do Brasil.
} 
anos em que funcionou o campo de concentração, cerca de um milhar de presos esteve por lá. Setenta por cento deles foram tragados pela doença, violência repressiva do Estado, ou pelas condições desumanas de vida e jazem no solo quente amapaense. Como a área pertence as Forças Armadas, os documentos oficiais estão inacessíveis. O pouco que se sabe sobre Clevelândia devemos a imprensa e aos relatos dos raríssimos sobreviventes.

Getúlio Vargas ao liderar a Aliança Liberal entre 1929 e 1930 tascou a frase na garganta de Washington Luís de que: "no Brasil a questão social era uma questão de polícia”. A República Velha seguiu à risca o vaticínio do político de São Borja.

Como um velho 'long play' a História insiste em tocar sucessivamente o mesmo lado. Nos anos 2000 foi criado o Regime Disciplinar Diferenciado (RDD) para acomodar líderes de facções criminosas, presos que reiteram crimes ou as lideranças de rebelião. Tais penitenciárias de segurança máxima, constantemente sofrem denúncias em cortes internacionais de direitos humanos. O maior de todos os presídios especiais paulistas - que trancafiou Fernandinho Beira-Mar e Marcola, respectivamente o maior traficante do país e o líder da organização Primeiro Comando da Capital (PCC) —, está localizado na cidade de Presidente Bernardes. O advogado, natural de Viçosa, sentir-seia honrado.

\subsubsection{Washington Luís ( 1926-1930)}

Coincidentemente, a última eleição para presidente da República Velha foi a mais calma. O mineiro Artur Bernardes entregava o poder ao ex-presidente de São Paulo, o "paulista de Macaé” Washington Luís. O lema de governo "governar é abrir estradas" trouxe o predomínio do transporte automobilístico e o esquecimento do setor ferroviário. As rebeliões populares foram poucas, entre elas temos o final da Coluna Miguel Costa-Prestes, ou somente Coluna Prestes.

\section{A Longa Marcha}

Isidoro Dias Lopes retira suas tropas da capital paulista em fins de julho de 1924. Por quase um mês os tenentes demonstraram sua força política e capacidade militar. Hélio Silva narra que no dia 27 de Julho de 1924 o presidente da Associação Comercial de São Paulo encontrou-se com Isidoro Dias Lopes. Deu-lhe conta que o Catete iria agir e: 
São Paulo iria ser destruída. Não apenas o grande sacrifício de vidas inocentes, mas também o parque industrial da capital paulista preocupava Macedo Soares. Seria o incêndio de fábricas e oficinas, a destruição do poder industrial e do poder econômico, seria o aniquilamento financeiro do Brasil. (...) fez um apelo aos revolucionários para que depusessem as armas, provocando, desse modo, uma possibilidade de receberem uma ampla anistia. ${ }^{170}$

Após longas reuniões com os comandantes da rebelião, Isidoro anuncia no dia seguinte a retirada das tropas da capital e a transferência do governo provisório para o interior. Tudo para poupar seus patrícios de “ uma destruição desoladora, grosseira e infame e poupar a pátria de um tremendo vexame."

Isidoro Dias Lopes parte em direção ao Paraná. Estabelece o quartel general dos tenentes em Foz do Iguaçu. No caminho enfrentam as tropas federais lideradas por Cândido Rondon. Somente em outubro de 1924 o movimento tenentista obtém vitórias no Rio Grande do Sul, sob a liderança do capital Luiz Carlos Prestes. Este lidera seus homens pelo interior do Sul do país e em abril encontra o quartel general de Isidoro Dias Lopes.

Numa reunião que contou com a presença de Isidoro Dias Lopes, Miguel Costa, Luís Carlos Prestes e do general Bernardo Padilha, foi tomada a decisão de prosseguir a marcha. O comando da força revolucionária ficou a cargo do general Miguel Costa, tendo como chefe de estado-maior o coronel Luís Carlos Prestes ( depois receberá o título de general de brigada). Nascia a Coluna Miguel Costa-Prestes ou Coluna Prestes. Seu trajeto é que se segue:

Iniciando a marcha, a coluna concluiu a travessia do rio Paraná em fins de abril de 1925 e penetrou no Paraguai rumo a Mato Grosso. Em seguida, percorreu Goiás, entrou em Minas Gerais e retornou a Goiás. Seguiu em direção ao Nordeste e em novembro atingiu o Maranhão, onde o tenente-coronel Paulo Krüger foi preso e enviado a São Luís. Em dezembro, penetrou no Piaú e travou em Teresina sério combate com as forças do governo. Rumando então para o Ceará, a coluna teve outra baixa importante: na serra de Ibiapina, Juarez Távora foi capturado.

\footnotetext{
${ }^{170}$ SILVA, Hélio. Artur Bernardes. Pág. 124
} 
Em janeiro de 1926, a coluna atravessou o Ceará, chegou ao Rio Grande do Norte e, em fevereiro, invadiu a Paraíba, enfrentando na vila de Piancó séria resistência comandada pelo padre Aristides Ferreira da Cruz, líder político local. Após ferrenhos combates, a vila acabou ocupada pelos revolucionários.

Prosseguindo a marcha rumo ao sul, a coluna atravessou Pernambuco e Bahia e dirigiu-se para o norte de Minas Gerais. Encontrando vigorosa reação legalista e precisando remuniciar-se, o comando da coluna decidiu interromper a marcha para o sul e, em manobra conhecida como "laço húngaro", retornar ao Nordeste através da Bahia. Cruzou o Piauí, alcançou Goiás e finalmente chegou de volta a Mato Grosso em outubro de 1926.

Entre fevereiro e março de 1927, afinal, após uma penosa travessia do Pantanal, parte da coluna, comandada por Siqueira Campos, chegou ao Paraguai, enquanto o restante ingressou na Bolívia. ${ }^{171}$

Quase dois anos de uma longa e extenuante Marcha. Foram mais de $25.000 \mathrm{~km}$ de percurso, ou seja, mais da metade de uma volta a terra. Enfrentaram frio, calor, áreas de florestas densas, rios caudalosos e dezenas de batalhas contra as tropas federais. Jamais foram derrotados. Muitos dos "tenentes" foram figuras proeminentes da Nova República que se iniciaria após 1930. Personagens como Miguel Costa, Juarez Távora, Siqueira Campos e a maior liderança comunista entre os anos 30 e 70, Luís Carlos Prestes.

\subsubsection{O Ocaso do Café-com Leite}

Os anos de 1928 e 1929 davam claros sinais de uma crise de super-produção nas potências capitalistas. Os mercados estavam inundados de bens-de-consumo e a produção de café continuava a ser nosso alicerce. Uma commoditie que havia demonstrado várias vezes que era muito sensível às flutuações nas economias centrais e aos ciclos de crescimento e recessão do mundo industrial. Mais uma vez o governo brasileiro se endivida para bancar o café.

As eleições presidenciais da sucessão de Washington Luiz não foram calmas. O paulista de Macaé deixa de lado a aliança São Paulo-Minas que esperava pela indicação

\footnotetext{
${ }^{171}$ Verbete “ Coluna Prestes” do projeto CPDoc-FGV. Disponível em: http://cpdoc.fgv.br/producao/dossies/AEraVargas1/anos20/CrisePolitica/ColunaPrestes. Acessado em 03/09/2016.
} 
de Antonio Carlos Ribeiro de Andrada, então presidente do estado mineiro. Andrada, entre outras coisas, era um dos maiores defensores da segunda tentativa de Farquhar no Brasil, o projeto da Itabira Iron. O empresário americano aguardava ansioso sua eleição. Porém, o escolhido foi o paulista de Itapetininga, Júlio Prestes de Albuquerque. O $13^{\circ}$ presidente paulista eleito acabou nunca assumindo. Sua escolha desagradou as elites mineira, gaúcha e paraibana. Eles lançam a Aliança Liberal. A chapa era encabeçada pelo ex-ministro da Fazenda de Washington Luiz, o gaúcho Getúlio Vargas como candidato a presidente e o paraibano João Pessoa a vice-presidência. Nas eleições em $1^{\circ}$ de Março, Julio Prestes obteve 59,6\% dos votos, mas sua eleição só ocorreu pelo resultado na terra natal, afinal em São Paulo ele conseguiu 91\% dos votos. Em maio, em plena crise mundial e política, seu Julinho faz um tour pela Europa e Estados Unidos (foi o primeiro brasileiro a estampar a capa da Time) e voltou apenas em agosto. Dois meses depois estourava a revolução popular. Em fins de Outubro, Washington Luiz é deposto. No 3 de Novembro de 1930, Getúlio Vargas amarrava seu cavalo no palácio do Catete para dali arribar somente 15 anos depois. Nascia a Nova República. O governo revolucionário de Getúlio agregava parte das elites antigas, a ascendente burguesia industrial e os tenentes. O mundo estava dividido entre fascistas, comunistas e norteamericanos. Por aqui, os três grupos irão, dependendo das circunstâncias, contra ou a favor do presidente que mais tempo nos governou.

O nacionalismo getulista contra o imperialismo, a perda de oportunidades com a Grande Guerra, a crise econômica-financeira de 1929, o $3^{\circ}$ funding loan (1931) e as lutas contra o socialismo e integralismo marcarão a face dos anos 30. Percival Farquhar encontrará em Getúlio Vargas um empecilho ao projeto da Itabira Iron. O pai dos pobres irá protelar a sentença de morte de Farquhar por 12 anos. 


\section{CAPÍTULO 6 - CONTEXTO MUNDIAL}

Um dos livros mais famosos e mais interpretados da Bíblia é o Apocalipse. Escatológico, narra de forma simbólica, poética e alegórica o fim da História. Tal mitologia permite a devaneios de todos os tipos. Tratar como verdade histórica um documento religioso é o mais comum deles.

A História do Brasil estudada nesta Tese vai de 1898 a 1931. Em meio a 3 funding loans e os investimentos de Percival Farquhar observamos quatro grandes ciclos perturbadores da ordem mundial. Todos os eventos estabeleceram mudanças na sociedade e economia brasileiras.

Começamos pelo Imperialismo e sua partilha do mundo, erigindo uma nova divisão internacional do trabalho e a consequente dependência econômico-financeira das nações não industrializadas. Seguindo na cronologia apresenta-se a Grande Guerra de 1914 a 1918. Teria ela permitindo um choque adverso na economia brasileira? O terceiro ciclo ocorre com a Revolução Russa de Outubro de 1917. Com o comunismo temos o grande inimigo do capitalismo liberal, mas a solução para a sua revitalização: o Medo. Para encerrar o estudo do contexto histórico mundial apresenta-se a Crise de 1929, a maior depressão de toda a história do sistema capitalista.

São quatro eventos que remetem a passagem bíblica do Apocalipse sobre a abertura dos sete selos e os quatro cavaleiros anunciando o fim dos tempos. Curtos 8 versículos que produziram centenas de análises e interpretações ao longo da história:

Capítulo 6. Versículos:

$1 \mathrm{E}$ vi quando o Cordeiro abriu o primeiro dos sete selos, e ouvi um dos quatro seres viventes dizer com voz de trovão: "Vem".

2 E vi um cavalo branco aparecer. Seu cavaleiro tinha um arco, ele recebeu uma coroa e saiu vitorioso, para uma nova conquista.

3 Quando o Cordeiro abriu o segundo selo, ouvi o segundo ser vivente que dizia: "Vem".

$4 \mathrm{E}$ vi outro cavalo aparecem em vermelho como fogo. O cavaleiro foi dado o poder de banir a paz da terra, de modo que os homens matam uns aos outros; e foi-lhe dada uma grande espada.

5 Quando abriu o terceiro selo, ouvi o terceiro dos seres viventes dizendo: "Vem". E eu vi um cavalo preto aparecer. Seu cavaleiro tinha uma balança na mão; 
6 E ouvi uma voz entre os quatro seres viventes, dizendo: "A ração de trigo é vendido por um centavo e três rações de cevada por um denário. E não estragar o azeite e o vinho".

7 Quando o Cordeiro abriu o quarto selo, ouvi o quarto dos seres viventes dizer: " Vem"

8 E eu vi um cavalo amarelo esverdeado. Seu cavaleiro foi chamado de "Morte" e o abismo da morte o seguia. E ele recebeu o poder sobre a quarta parte da terra para matar pela espada, fome, peste e animais ferozes. ${ }^{172}$

O Imperialismo é a fase final do Capitalismo. É o cavaleiro anunciando a Conquista, devidamente montado num cavalo branco, afinal o ideal civilizatório caminhava lado a lado com colonização de nova era e velhos hábitos.

O cavalo vermelho carrega junto com ele a espada da Guerra. Espada que irá sangrar como nunca a vida na Europa e cortará a terra ao meio nas terríveis trincheiras.

"Paz, Terra e Pão" bradava Lênin em abril de 1917. O terceiro cavaleiro tem como condutor o homem. Este carrega em suas mãos a balança. Balança da desigualdade e da fome. Os ventos frios do leste europeu trouxeram a luta contra a fome.

De uma cor pútrida é o último dos quatro cavalos. O cavaleiro é uma águia. Nada mais simbólico para a derrocada da economia americana e sua crise de 1929. A águia esfacelada e com paúra de que o capitalismo esteja perto do fim.

Conquista, Guerra, Fome e Morte personificados na História.

\section{1. Primeiro Cavaleiro: A Conquista}

O período entre os anos 70 do século XIX e o início da Primeira Guerra (1914) ficou conhecido como Imperialismo ${ }^{173}$ segundo Hobsbawm por dois motivos: por ter inaugurado uma nova forma de imperialismo ( distinto dos modelos da História Antiga, como os da Grécia e Roma escravistas, por exemplo) e também pela existência de

\footnotetext{
${ }^{172}$ A Bíblia. Sagrada Escritura. Acessado em 17/09/2016. http://www.vatican.va/archive/bible/index po.htm

173 Parte desta explanação sobre Imperialismo foi retirada da Dissertação de Mestrado que defendi na FFLCH-USP - Departamento de História Econômica em 2011, denominada “ Congo Belga: Imperialismo, a Roedura Geopolítica (1885-1908)”. Justifica-se essa utilização, primeiro porque entendo que as condições determinantes do Imperialismo, bem como as interpretações ali fornecidas não tenham sido superadas. Outro fator é a importância do Imperialismo para a entrada no Brasil do personagem central desta Tese, Percival Farquhar. Ele era um misto de Cecil Rhodes com toques de Rockfeller. Utilizou-se do sistema financeiro para obter capital para os investimentos e ampliação das empresas estrangeiras num país em crescente processo de industrialização, mas totalmente carente de uma infra-estrutura como as estradas de ferro, portos, eletricidade, bondes para transporte coletivo, entre outros serviços. Esta terra era muito perto da África neocolonial para os interesses do truste Syndicate Farquhar.
} 
dezenas de países importantes na época com esse nome de governo, entre eles o Império Brasileiro de D. Pedro II. Para Leila Hernandez o termo tem em comum o fato de:

[...] se referirem a uma expansão por parte dos Estados caracterizada por forte assimetria e violenta dominação que se manifesta de formas diversas, como nas relações de preponderância das metrópoles sobre as áreas de influência, protetorados e colônias [...] ou, ainda, nas diversas facetas da política de dominação e exploração praticada em diferentes proporções pelos Estados ricos em relação aos Estados pobres. ${ }^{174}$

Charles Conant inaugura em 1898 a explicação econômica do Imperialismo ao afirmar que o mesmo era essencial para o Capitalismo por se tratar de uma forma de se livrar dos excedentes de produção. Inerente ao sistema produtivo e um verdadeiro descongestionante para o livre mercado. Sem moralismo ele afirmava em "As bases econômicas do imperialismo" que:

Pode-se discutir se esta política [imperialista] suporta o governo direto sobre grupos de ilhas semisselvagens (sic), mas do ponto de vista econômico da questão não há senão uma opção: ou entrar por algum meio na competição para o emprego de capital e empreendimentos americanos nesses países, ou continuar com a desnecessária duplicação dos existentes meios de produção e comunicações, com a consequente superabundância de produtos não consumidos, as convulsões que se seguem da paralisia do comércio, e a constante queda dos lucros sobre os investimentos que tal política negativa trará vinculada. ${ }^{175}$

A história procurou ( e ainda procura) detectar as condições econômicas, políticas e ideológicas que levaram ao imperialismo e sua expansão colonial para a África e áreas do Pacífico em fins do século XIX. A expansão dos espaços geográficos foi outra característica do período, como explica Edgar de Decca:

A principal característica desse processo desenfreado por ampliação de espaços era a de que a ampliação dos Estados europeus tinha sido motivada por uma necessidade irrefreável da ampliação dos mercados

\footnotetext{
${ }^{174}$ HERNANDEZ, Leila Leite. A África na sala de aula. pp. 72-73

${ }^{175}$ Citado por Gomes Barbosa, Glaudionor. In: Imperialismo, Capitalismo e burguesia Revisitando as contribuições teóricas de Joseph Schumpeter e Hannah Arendt. pp.147-148
} 
das economias competitivas do capitalismo industrial. Isto significava uma mudança radical no modo de organização política dos estadosnações, uma vez que as suas fronteiras tornaram-se restritivas e constrangedoras para a expansão dos mercados capitalistas. Se as fronteiras nacionais tinham sido até então a base de sustentação do edifício político dos estados, as forças avassaladoras do capitalismo industrial pressionavam para que essas fronteiras fossem rompidas e expandidas a uma dimensão sem precedentes. ${ }^{176}$

Porém era um colonialismo de face nova sobre velhas práticas. $\mathrm{O}$ escritor Rudyard Kipling ( nascido na Índia britânica em 1865 e falecido em 1936), imortalizou as imagens da responsabilidade civilizatória do europeu em meio a barbárie. Não bastava buscar riquezas, colonizar agora era um ato de fé banhado a muito sangue. Publicado em 1899, o poema “The White man's burden” ( o fardo do homem branco) diz em seus versos iniciais:

Tomai o fardo do Homem Branco

Envia teus melhores filhos

Vão, condenem seus filhos ao exílio

Para servirem aos seus cativos;

Para esperar, com arreios

Com agitadores e selváticos

Seus cativos, servos obstinados,

Metade demônio, metade criança.

(...)

Tomai o fardo do Homem Branco

As guerras selvagens pela paz

Encha a boca dos Famintos,

E proclama, das doenças, o cessar; (...)

John Atkinson Hobson (1858-1940) em 1902 que a definição de Imperialismo ganhou 'status' de interpretação científica. O economista inglês tratou em "A evolução do capitalismo moderno" do processo de concentração e centralização do capital dos fins do século XIX. Além de descrever a formação dos cartéis, trustes e holdings, nessa

\footnotetext{
${ }^{176}$ DECCA, Edgar de. O colonialismo como a glória do império. In.: REIS FILHO, Daniel Aarão, FERREIRA, Jorge \& ZENHA, Celeste. O século XX - o tempo das certezas. Volume 1 Civilização Brasileira. 2000. São Paulo. Pág. 155
} 
obra, Hobson demonstra o crescente predomínio do capital financeiro sobre o capital industrial, pois a " estrutura do Capitalismo moderno tende a lançar um poder cada vez maior nas mãos dos homens que manejam o mecanismo monetário das comunidades industriais - a classe dos financistas". ${ }^{177}$

Para Hobson, o Imperialismo não era uma fase do Capitalismo ( como entendeu Lênin). Formou-se historicamente em meio a uma crise entre super-produção e subconsumo ( no que ele concordava com Rosa de Luxemburg). A expansão dos territórios era uma solução para a super-produção, pois dessa forma, o Capitalismo teria novos mercados. Melhorar as condições de trabalho e dos trabalhadores seria a maneira de encerrar o momento 'passageiro' do Imperialismo, pois cresceria o mercado interno, eliminando o sub-consumo e retomando o equilíbrio. Ou seja, o Imperialismo não seria nem a etapa final do Capitalismo ( muito menos uma fase) como afirma Lênin e a mais valia não seria uma necessidade sagrada da burguesia, como nos diz Luxemburgo. Bons homens esses reformadores.

Para o historiador cultural, Edward Said, em seu estudo 'geográfico da história', fala da desigualdade entre metrópoles e colônias, da avidez por comércio, mercados e trabalhadores baratos. Culturalmente afirma que os impérios são iguais no processo de colonização e exploração das riquezas:

Nunca existiu em toda a história um conjunto de colônias tão grande, sob domínio tão completo, com um poder tão desigual em relação às metrópoles ocidentais.(...) E na própria Europa, no final do século XIX, não havia praticamente nenhum aspecto da vida que não fosse tocado pelos fatos do império; as economias tinham avidez por mercados ultramarinos, matérias primas, mão-de-obra barata e terras imensamente rentáveis, e os sistemas de defesa e política exterior empenhavam-se cada vez mais na manutenção de vastas extensões de territórios distantes e grandes contingentes de povos subjugados. Quando as potências ocidentais não estavam mergulhadas em uma disputa acirrada e às vezes implacável por maior número de colônias - todos os impérios coloniais imitavam-se uns aos outros estavam se esforçando para colonizar, fazer levantamentos, estudar e, naturalmente, governar os territórios sob suas jurisdições. ${ }^{178}$

\footnotetext{
177 HOBSON, A evolução do capitalismo moderno. p.175

178 SAID, Edward. Cultura e imperialismo. pp 37-38
} 
Para a economista, filósofa e ativista política Rosa de Luxemburgo, o Imperialismo seria a expressão política do processo de expansão do capital, caracterizada por uma competição das áreas do globo ainda não conquistadas. Com o fim do livre cambismo - que só permaneceu mais tempo na Inglaterra pelas dimensões e antiguidade daquele império - , a disputa só poderia ser resolvida pela violência entre os Estados centrais. O militarismo era a moeda necessária do Imperialismo. Para garantir o capital e as conquistas, o Estado desenvolve um aparato militar, com soldados e armas. O capital necessário para essa atividade vem dos impostos recolhidos seja dos salários dos trabalhadores, seja da mais valia dos burgueses. Para o primeiro grupo significa uma expropriação desnecessária e para o segundo grupo uma possibilidade de investimento, com a conquista de novas terras (as colônias), antes não-capitalistas ou pré-capitalistas, portanto não-consumidoras das mercadorias de uma burguesia expansionista.

O capitalismo então seria intrinsecamente expansionista e universal. Um sistema econômico que se quer solitário, mas necessita de áreas distantes para a sua expansão. Uma forma histórica de crises e soluções, que dialeticamente produzem novas crises, as quais, só serão solucionadas pelo esgotamento dessas possibilidades, na visão da autora, numa sociedade socialista.

Foi na obra do líder da Revolução Russa que o Imperialismo teve sua mais profunda análise econômica. Lênin define o primeiro cavaleiro, o da conquista como:

[...] é a fase monopolista do capitalismo. Essa definição compreenderia o principal, pois, por um lado, o capital financeiro é o capital bancário de alguns grandes bancos monopolistas com o capital das associações monopolistas de industriais, e, por outro lado, a partilha do mundo é a transição da política colonial que se estende sem obstáculos às regiões ainda não apropriadas por nenhuma potência capitalista para a política colonial de posse monopolista dos territórios do globo já inteiramente repartido. ${ }^{179}$

No capítulo VII, 'Imperialismo, fase particular do capitalismo', Lênin apresenta as cinco características definidoras do período: em primeiro lugar, o processo de concentração de capital e de produção ( as empresas capitalistas tornaram-se cada vez maiores em dimensão, número de trabalhadores e produção), o que levou as mesmas a

${ }^{179}$ LÊNIN. Imperialismo, fase superior do capitalismo. Capítulo VII. Pág.39 
um processo de fusões, incorporações e constituições de monopólios ( como os trustes norte-americanos e os cartéis prussianos); essa indústria centralizada e monopolizada fundiu-se ao capital bancário, fazendo nascer a oligarquia financeira e o predomínio do capital financeiro sobre o industrial; dessa forma a exportação de capitais adquire prevalência em relação à exportação de mercadorias; e constituem-se as associações internacionais entre os capitais monopolistas, repartindo economicamente o mundo entre si; temos que, por último, a partilha territorial do mundo se dá entre as potências hegemônicas do capitalismo.

Para Marx e Lênin os bancos nada mais são do que a contabilidade geral do sistema capitalista. Aos poucos, ocorre uma união pessoal entre os bancos com as grandes indústrias e destes dois com os governos. Assim, tais instituições adquirem uma face mundial. Aos pequenos e médios bancos, além das pequenas e médias empresas, cabem as lamúrias de um mercado centralizado, monopolizado e internacional.

Começa a era do Capitalismo Financeiro. Concentrado nas mãos de poucos monopolistas, o capital financeiro obtém lucros cada vez maiores, com a emissão de valores, ações, empréstimos a empresas e Estados, fortalecendo as oligarquias bancárias e impondo pesados tributos a sociedade. Lênin vai além ao afirmar que se os lucros financeiros se avolumam em épocas de abastança, nas de crise econômica crescem as aquisições de empresas falidas, aumentando o poder e a centralização de capital.

A livre concorrência é a característica fundamental do capitalismo. O monopólio é seu adverso. Porém, contraditoriamente, com a expansão ilimitada da capital e da acumulação, o Imperialismo e a concentração tornaram-se um desenvolvimento lógico e necessário do sistema. O que caracteriza o Imperialismo é o predomínio do capital financeiro e a luta entre as nações centrais. Os monopólios não atenuam essas características, ao contrário, as acirram. A Grande Guerra era uma condição necessária do Imperialismo. A partilha do mundo produzira a falsa noção de que os países centrais dividiriam pacificamente a exploração colonial.

[...] uma aliança geral de todas as potências imperialistas, só podem ser, inevitavelmente 'tréguas' entre guerras. As alianças pacíficas preparam as guerras e por sua vez surgem das guerras, conciliando-se mutuamente, gerando uma sucessão de lutas pacíficas e não pacíficas sobre uma mesma base de vínculos imperialistas e de relações recíprocas entre a economia e a política mundiais. ${ }^{180}$

${ }^{180}$ LÊNIN. Imperialismo, fase superior do capitalismo. Capítulo IX. Pág.53 
Imperialismo é o capitalismo de monopólios, sendo que estes se formaram e ainda continuam nesse caminho concentrador a partir da centralização da produção iniciada nos fins do século XIX. Monopolizado o capital, agudizou-se a luta pelas fontes de matéria-prima barata e abundante, nas áreas coloniais, o que fez aumentar o poderio dos conglomerados e aumentar o fosso entre as empresas monopolistas e as empresas simples. Os monopólios se mundializaram. Os bancos também se cartelizaram e de sócios, tornaram-se controladores do capital industrial e financeiro.

Lênin encerra seu livro acusando os economistas burgueses de "contar as árvores, sem observar os bosques". O que se esconde por trás do 'entrelaçamento' burguês são as relações sociais de produção. O monopólio e o capital financeiro por um lado, a partilha e a exploração colonial de outro, tendo a guerra inevitável como consequência. Não estão isolados, pertencem todos ao Imperialismo, como fenômeno econômico e político, determinante das relações sociais do período.

Os historiadores costumam inserir a expansão neocolonialista do Imperialismo nos continentes africano e na região do Sudeste asiático. Porém, sabemos que a teoria e a prática do capitalismo financeiro e monopolista se estendeu por todo o Globo. E a América Latina não fugiu às garras dessa expansão. Theodore Roosevelt e sua política do Big Stick que o digam. Percival Farquhar personificou essa tentativa de conquista imperialista. Investiu em quase toda a Nossa América como diria José Martí. Por aqui, Farquhar passou quase 50 anos. Inspirando ódios, recalques, recebendo agrados e concessões; virou até personagem de romances.

Marcio Souza, escritor manauara, ambientou um de seus romances na trágica construção da ferrovia Madeira-Mamoré e a personagem de Farquhar. Num certo sentido, a imagem de um empresário sem escrúpulos morais quando se trata de obter lucro, que se utiliza das mais sórdidas artimanhas para conseguir as concessões se perpetua na obra. Vejamos alguns trechos:

Lembrou de Farquhar e aquela lembrança tinha o odor de irritação pantanosa. Farquhar era o único homem capaz de fazer de todos os horrores uma coleção de feitos grandiosos porque davam lucro. Ele e o jovem médico não pertenciam a mesma família animal à qual pertencia Farquhar, ...[ele] era como uma infecção invisível que todos observavam e não viam mais do que uma cicatriz benigna. 
Mackenzie [ sócio de Farquhar no Brasil, comentário nosso] às vezes podia ser aterrador e, se não trabalhasse no Brasil, seus métodos truculentos poderiam ser considerados por Farquhar como imprudentes. Era um facínora refinado, sem sutilezas, capaz de vencer a própria mãe se isso lhe desse poder. Esta era a diferença entre eles. Mackenzie queria poder, gostava de poder. Farquhar preferia acumular riquezas, uma forma de poder muito maior e nunca perigosamente explícita.

Farquhar quase nunca visitava Mackenzie, pois se sentia pouco à vontade naqueles jardins luxuriantes. Mackenzie tinha uns dez empregados negros, todos rapazes bem novos que ele contratava nas fazendas de café do interior. Era conhecido como 'papa crioulos' e Farquhar soubera através da amante do ministro J.J. Seabra que este se referia ao seu sócio como o 'viadão ianque'. Farquhar precisava afastar o seu representante de todas as manobras necessárias para aproximá-lo do novo governo. No Brasil, a virilidade era menos importante do que o dinheiro... ${ }^{181}$

Farquhar era uma infecção necessária, uma doença típica da necessidade de desenvolvimento. Não possuía a depravação moral do seu sócio, afinal era um 'quacre'. Aceitava as luxúrias e por meio de intrigas e amizades interesseiras conquistava seu pequeno Império sul-americano. Visava a mais absoluta forma de poder, o silencioso e invencível poder do dinheiro. Farquhar não era diferente dos Guinle, dos Matarazzo, dos Calfat em suas práticas e políticas. Mas nascera com um defeito incurável: não era brasileiro.

\section{2. Segundo Cavaleiro: A Guerra}

\subsubsection{A Guerra contra Todos}

Alfred Von Schlieffen foi chefe do Estado Maior do Império Prussiano entre 1891 a 1906. Para os germanos tratava-se de um gênio militar. Iniciada a Primeira Guerra, o plano dele foi colocado em prática: atacar a potência maior, a França e depois resolver o problema no lado leste com a desorganizada Rússia. Invadidas a Bélgica, a Holanda e Luxemburgo, as tropas alemãs penetram pelo território francês em setembro 
de 1914. Mas ao contrário do que imaginavam os alemães, o resultado da longa batalha do Marne esteve bem distante da vitória na Guerra Franco-Prussiana ( 1870-1871). Os meses e as mortes se somavam. Aos poucos, na frente ocidental, prussianos, franceses e britânicos foram construindo duas imensas crateras — uma defronte à outra - , sobre o solo frio do inverno europeu. Nascia a terrível guerra de trincheiras.

As fortificações britânicas e francesas eram divididas em três áreas. Primeiro vinha a linha de frente, em que ocorriam a maior parte dos combates e mortes. Ali as metralhadoras cuspiam fogo quase o dia todo. Logo atrás desta aparecia a linha de controle. Nela encontrava-se o sistema de comunicações, os banheiros, o depósito, o breve refúgio ao zunir de balas e bombas. Por último, construiu-se a linha de apoio. Distante de 90 a 500 metros das trincheiras de controle e de frente. Soldados de reserva, armamentos e algumas fortificações. Era o último contato dos soldados com a estrutura genocida das trincheiras. Entre a linha de frente e a trincheira inimiga havia um campo protegido por imensos cordéis de arame farpado de ponta a ponta. Com 100 a 360 metros de distância entre os dois lados da guerra, havia o que ficou conhecido como a Terra de Ninguém. Os avanços na linha de fogo se davam nesse espaço livre, observados apenas pelos mortos e feridos que apodreciam na terra.

As crateras que sangraram o território francês, da fronteira com a Bélgica até a região central do país, possuíam dezenas de quilômetros de corredores subterrâneos em forma de ziguezague. Cada trincheira possuía em média de 9 a 12 metros de extensão e estavam separadas umas das outras por parapeitos, essenciais para o descanso nas intermináveis batalhas, ou como aparas para a fumaça das armas e, posteriormente, para proteger dos intoxicantes gases.

Nesses buracos fétidos, tomados por ratos, doenças e insetos. Insanamente quentes no verão, congelantes no inverno e completamente alagados nas estações pluviais, viveram milhões de soldados por quase 4 anos. As mortes em combate eram vultosas e jamais vistas no mundo. A grande maioria dos 119 mil soldados norteamericanos mortos na Grande Guerra perdeu sua vida nas trincheiras. A primeira grande luta se deu em Marne ( em 1914, nas três primeiras semanas de setembro), na qual 65 mil franceses morreram. Na batalha de Verdun ( de fevereiro a dezembro de 1916), França e Reino Unido perderam quase 400 mil homens cada uma. Somme ( de maio a novembro de 1916) assistiu o desfalecimento de 60 mil soldados britânicos em apenas um dia. Talvez uma das mais traumáticas experiências humanas da História. Não só humanas. 
Na batalha de Verdun, Satan ( protegido com máscara de gás) carregava sua sacola com dois pombos-correios, um de cada lado. No corpo das aves, uma mensagem que mostrou-se decisiva para a vitória da 'Entente'. Satan serpenteava pela Terra de Ninguém. Corria em ziguezague conforme treinamento realizado nas divisas francesas. Perto do fim da missão, um projétil acertou-lhe a perna dianteira. Satan desfalece na terra, o sangue jorra-lhe pelas veias, os olhos adormecem. Seu superior, o sargento Duvalle, o acompanhava correndo protegido na linha de frente. Vendo o desfalecimento do amigo na Terra de Ninguém, ele grita para que Satan continue sua incumbência. Cambaleante, o pequeno heroi francês caminha até o destino, cumpre o dever e entregase de dor. Os soldados que esperavam o cachorro Satan retiram os pombos-correios, recebem a mensagem decisiva. Dias depois, a Prússia era derrotada.

Satan não foi o único cachorro, muito menos o único animal a participar ativamente da Primeira Guerra. Um genocídio pouco conhecido do passado militar foram os animais. Historiadores calculam em 8 milhões de cavalos mortos e 1 milhão de cachorros ( ninguém sabe o destino posterior de Satan). Gatos eram presença obrigatórias em navios e submarinos ( na maioria das vezes para caçar ratos). Milhares de pombos foram treinados de forma intensa e torturante ( tendo até de carregar pequenos protótipos de câmeras fotográficas). Camelos, elefantes, mulas e bois também foram utilizados. Rebanhos, vez ou outra eram incendiados. Uma arca de Noé às avessas. A utilização de animais -- domesticados ou não --, se dava por mera necessidade. Talvez apenas os britânicos criaram laços de amizades com cães e gatos. Para a maioria, Satan era apenas um cachorro que cumpriu sua missão com sua pata estraçalhada e posterior esquecimento. A História nunca pode observar o passado com os desejos do presente. Jamais poderá educar os mortos.

\subsubsection{A Guerra em Si}

As disputas imperialistas e ascensão impressionante do Império Prussiano ( em 1851 a produção industrial do país correspondia a 45\% do total realizado pela Inglaterra, duas décadas depois o país se unifica e em 1891 a produção alemã é 14\% maior que a inglesa), podem ser utilizadas para se explicar a origem da Grande Guerra. Mas em fins do século XIX, a política de alianças entre as potências europeias colocava em risco o período de quase um século de paz no continente ( com exceção das Guerras 
da Crimeia e Franco-Prussiana, curtas e de poucas baixas como atesta Hobsbawm ${ }^{182}$ ), desde o fim das guerras napoleônicas em 1814. De um lado forma-se a Tríplice Aliança entre Império Prussiano, Império Austro-húngaro e a titubiante Itália ( que após uma bela propina em 1915 vira para o outro lado). Eram os Impérios Centrais que após o início da Guerra contaram com a adesão da Turquia. No outro extremo organizou-se a Tríplice Entente entre França, Rússia e Inglaterra. Depois de 1917, contaram com a ajuda decisiva dos Estados Unidos.

As intrincadas alianças tiveram um efeito dominó. Provocada uma nação e declarada guerra a esta, um aliado precisava defendê-la contra o inimigo. Este por sua vez, ao ser atacado por duas nações recebia o auxílio de um aliado do bloco. O famoso estopim é o assassinato do arquiduque e herdeiro do trono Austro-Húngaro, Francisco Ferdinando. Em visita a ocupada e incorporada Bósnia em junho de 1914, um jovem sérvio-bósnio pertencente ao grupo radical 'Mão Negra', mata o arquiduque e sua esposa. A pressão Austro-húngara sobre a Sérvia foi brutal. A Rússia foi obrigada a socorrê-la. Imediatamente o Kaiser alemão respondeu:

Imprudência e fraqueza mergulharão o mundo numa guerra terrível cujo objetivo é destruir a Alemanha. Pois não pode mais haver qualquer dúvida: a Inglaterra, a França e a Rússia vem conspirando para travar uma guerra de aniquilação contra nós. ( Kaiser Guilherme II em memorando enviado a 30 de julho de 1914, em resposta a mobilização russa anterior). ${ }^{183}$

Pouco mais de um mês depois, quase uma dezena de países europeus estavam em Guerra. Até então o maior conflito da História. Foram quatro anos e quatro meses de batalhas sangrentas. No início estabeleceram-se as frentes oeste ( com as descritas trincheiras) e leste com o enfrentamento massivo prussiano contra a Rússia. Mas aos poucos o conflito se estendeu para os Bálcãs, para o Planalto da Anatólia e em terras africanas. Estatísticas falam em 10,5 milhões de mortos e um número semelhante de mutilados e feridos. Hobsbawm atenta para o fato de que a Grande Guerra foi mais traumática pelas inovações trazidas em combates e pelo sofrimento causado a parte da elite ( um quarto dos jovens homens de Cambridge e Oxford morreram na Guerra).

\footnotetext{
${ }^{182}$ HOBSBAWM, Eric. A era dos extremos. São Paulo. Companhia das Letras. 1997. Passim.

${ }^{183}$ WILMOTT. H.P. Primeira guerra mundial. Editora Nova fronteira. São Paulo. 2008. Pág. 11
} 
Armas de destruição que seriam aperfeiçoadas na Segunda Guerra, mas sem o impacto da inovação. Na Grande Guerra tivemos as balas em série das metralhadoras, a força brutal e aniquiladora dos tanques, os primeiros ataques aéreos, os silenciosos e terríveis combates submersos dos submarinos, os encouraçados e torpedeiros. Até o desengonçado Zeppelin metia medo. Foi a Guerra das máscaras de gás, afinal a utilização de armas químicas se deu em larga escala. Gás como o mostarda, que em contato com o corpo ia chamuscando os olhos e narinas e depois penetrava na pele e fazia com que o soldado atingido sentisse dores lancinantes ( interna e externamente), além da descamação da pele. Mas nada se igualou ao túnel do terror que eram as trincheiras. Fato que não escapou de Erich Maria Remarque e seu diário de guerra:

Para nenhum homem a terra é tão importante quanto para um soldado. Quando ele se comprime contra ela demoradamente, com violência, quando nela enterra profundamente o rosto e os membros, na angústia mortal do fogo, ela é seu único amigo, seu irmão, sua mãe. Nela ele abafa o seu pavor e grita no seu silêncio e na sua segurança; ela o acolhe e o libera para mais dez segundos de corrida e de vida, e volta a abrigá-lo: às vezes, para sempre! Terra, terra, terra! Ó terra, com teus relevos, tuas covas e tuas depressões, onde a gente pode se atirar e se agachar! Terra, nos espasmos de horror, no romper do aniquilamento, no grito mortal das explosões, tu nos deste a poderosa contracorrente que nos tira da inércia paroxística e torna a nos salvar a vida! A tormenta furiosa de uma existência quase destruída reflui de ti para nossas mãos, e nós, que escapamos, enterramo-nos em ti, e, na felicidade muda e nervosa de termos sobrevivido a esses minutos vencidos, nós te mordemos com fúria! ${ }^{184}$

Dois fatores decidiram o lado vitorioso: a retirada da Rússia em janeiro de 1918 e a entrada dos Estados Unidos em abril de 1917. Com a Paz de Brest-Litovski, a Alemanha pode centrar esforços no fronte ocidental. Porém, mesmo com a concentração de forças e armas, os quase quatro anos de guerra haviam praticamente esgotado a capacidade bélica alemã. O país estava arrasado economicamente. Os soldados não carregavam a mesma confiança dos anos iniciais dos conflitos. As atrocidades de guerra e o número excessivo de mortos assustava a todos. Junte-se a isso a presença marcante

${ }^{184}$ REMARQUE, Erich Maria. Nada de novo no front. L\&PM Editora. RS. 2005. Págs. 33, 34. 
dos Estados Unidos. O poderio econômico e militar do país era impressionante. Enquanto a Europa se trucidava numa guerra fratricida, o país de Wilson se armava com eficiência, era sustentado por uma indústria então a mais produtiva do mundo e guardava a maior parte do ouro da economia capitalista. Em 11 de Novembro de 1918 era assinado o armistício, a Primeira Guerra chegara ao fim.

\subsection{Terceiro Cavaleiro: A Fome. Anda Um Espectro pela Europa}

Lênin não se interessava por vestimentas. Andava com roupas surradas. O par de sapatos (único) estava pior do que a situação política da Rússia. Voltando do exílio suíço, em abril de 1917, um camarada bolchevique o convence a trocar os sapatos. Descendo na estação Finlândia, então parte do território russo, era a vez do terno. Krupskaia e Lênin são recebidos por Kamenev, Stálin e outros bolcheviques, além da cunhada Maria. Petrogrado seria o destino final. O camarada pressiona Vladimir: um líder revolucionário, um futuro chefe de Estado não poderia usar roupas velhas. Lênin responde incisivo:

— Vim aqui para fazer uma revolução, não para montar uma alfaiataria.

Meses depois, Lênin tomou de assalto as alfaiatarias russas. Daniel Aarão defende que foram várias as Revoluções Russas. ${ }^{185}$ A primeira em 1905 com a estrondosa derrota russa para o Japão e a organização dos Soviets. 1917 assistiu a duas grandes revoluções: uma burguesa em 16 de Fevereiro com o príncipe Lvov no poder e outra no 26 de Outubro ${ }^{186}$ com a liderança do camarada Lênin. Terminada a Guerra Civil Branca inicia-se a quarta revolução, a da Nova Política Econômica. A quinta e última é associada ao stalinismo e os planos quinquenais.

Os fatores da maior revolução socialista da História tem seis elementos: a ditadura tzarista, um império de quase 4 séculos de opressão e desigualdade; a estrutura fundiária semi-feudal do país em que milhões de russos morriam de fome, de um lado pela concentração fundiária e do outro pela exclusão do acesso à terra pela grande maioria da população russas; a existência de uma nobreza e senhores feudais

\footnotetext{
${ }^{185}$ FILHO. Daniel Aarão Reis. As revoluções russas e o socialismo soviético. Editora UNESP. São Paulo. 2003

${ }^{186}$ No ano de 46 a.C., Júlio César aprovou o Calendário Romano, conhecido como Juliano, ele perdurou sem questionamentos até 1582 d.C., momento em que o Papa Gregório XIII impôs um novo calendário (o Gregoriano). Os europeus foram deitar em 4 de Outubro de 1582, numa quinta feira de outono e acordaram na sexta dia 15. Dez dias a mais. Os matemáticos gregorianos ainda propuseram o seguinte: só seriam bissextos os anos centenários não divisíveis por 400. Dessa forma, 1600 foi bissexto e 1700 , 1800 e 1900 não. Resultado, a diferença entre o Calendário Juliano e o Gregoriano passou a ser de 13 dias a mais para este último. Portugal e Espanha ( e o Brasil) adotaram o gregoriano imediatamente. O Reino Unido no século XVIII. A Grécia apenas em 1926. Portanto, a Revolução Russa de Outubro, ocorreu em 8 de Novembro no calendário gregoriano. Por sinal, Lênin resolveu essa questão para os futuros soviéticos: a partir de 1 de janeiro de 1918 a Rússia passou a adotar o gregoriano.
} 
abarrotados de privilégios, cargos e verbas tzaristas, mas com pouco trabalho e distribuição de riquezas; o quarto elemento foi a desastrosa participação russa na Grande Guerra; a instituição dos Soviets ( conselhos administrativos de operários, camponeses e soldados, verdadeiras estruturas administrativas que comandavam algumas cidades no período que antecedeu outubro de 1917), a partir da batalha com o Japão em 1905; e por último, o atraso industrial e econômico ( no início do século XX, o Império Russo possuía apenas o décimo PIB do continente europeu; comparativamente, em 2016, mesmo após a crise do fim do socialismo e a desintegração do país em 15 repúblicas, o que restou da Rússia é a $5^{\text {a }}$ economia europeia).

Em Abril de 1917, dotado de intuição política ímpar, Lênin anuncia nas resoluções da questão agrária:

A existência da propriedade latifundiária da terra na Rússia constitui o baluarte material do poder dos latifundiários feudais e uma garantia da possível restauração da monarquia. Esta propriedade da terra condena inexoravelmente a massa imensa da população da Rússia, o campesinato, à miséria, à vassalagem e ao embrutecimento, e todo o país ao atraso em todas as esferas da vida. ${ }^{187}$

Para logo mais à frente definir em seu primeiro artigo da resolução que:

1. O partido do proletariado luta com todas as forças pela confiscação imediata e completa de todas as terras dos latifundiários da Rússia (assim como as terras de apanágio, da Igreja, da coroa, etc. ${ }^{188}$

A propriedade privada permanece. Terra dos latifundiários são as antigas terras feudais e seus privilégios de suserania e vassalagem. As terras de apanágio são as propriedades privadas da realeza e sua família e as de coroa, aquelas exclusivamente do tsar. A expropriação sem indenização seria realizada nas propriedades do antigo regime. Dessa forma, o líder da revolução de Outubro mantém a simpatia dos pequenos, médios e grandes proprietários russos, além é claro do campesinato sem terra.

\footnotetext{
${ }^{187}$ Resolução Sobre a Questão Agrária. V. I. Lénine. 13 de Maio (30 de Abril) de 1917. Fonte: Obras Escolhidas em Três Tomos, 1977, tomo 2, pág: 86 a 88. Edições Avante! - Lisboa, Edições Progresso - Moscovo. Tradução: Edições "Avante!" com base nas Obras Completas de V. I. Lénine, $5^{a}$ ed. em russo, t. 31, pp. 425-428. Transcrição e HTML: Fernando A. S. Araújo ${ }^{188}$ Resolução Sobre a Questão Agrária. V. I. Lénine. 13 de Maio (30 de Abril) de 1917. Fonte: Obras Escolhidas em Três Tomos, 1977, tomo 2, pág: 86 a 88. Edições Avante! - Lisboa, Edições Progresso - Moscovo. Tradução: Edições "Avante!" com base nas Obras Completas de V. I. Lénine, 5. ${ }^{a}$ ed. em russo, t. 31, pp. 425-428. Transcrição e HTML: Fernando A. S. Araújo
} 
Era necessário não só derrubar a revolução burguesa de fevereiro com Lvov e depois Kerenski. Primordial para a tomada do poder pelos Bolcheviques seria a adesão dos trabalhadores e proprietários rurais, afinal tratava-se da maioria da população do país.

Os quase três anos de Guerra Mundial haviam decepado a águia de duas faces (símbolo da Rússia Czarista). Quase 3 milhões de mortos. Campos incendiados. Produção econômica direcionada a abastecer soldados e suas tropas. Alimentos, matérias-primas, bens industriais, tudo levava a uma desorganização completa do país. Pelo menos uma centena de milhões de russos viviam em meio à fome e ao pavor. A grande maioria das famílias sobrevivia com o equivalente a US\$ 30 mensais.

Foram 6 meses e meio de batalhas diárias, lutas políticas, e, essencialmente um corpo-a-corpo com a população sofrida da Rússia. Na manhã de 25 de outubro de 1917 (7 de novembro no calendário gregoriano), Lênin anuncia aos cidadãos russos:

O Governo Provisório foi deposto. O poder de Estado passou para as mãos do órgão do Soviete de deputados operários e soldados de Petrogrado — o Comitê Militar Revolucionário —, que se encontra à frente do proletariado e da guarnição de Petrogrado.

A causa pela qual o povo lutou - a proposta imediata de uma paz democrática, a supressão da propriedade latifundiária da terra, o controle operário sobre a produção, a criação de um Governo Soviético - esta causa está assegurada.

Viva a revolução dos operários, soldados e camponeses!

Tomado o poder, a liderança bolchevique enfrentou 4 anos terríveis. Mais árdua do que a própria revolução foram: a sabotagem na cidade e nos campos; a permanência da Rússia na Grande Guerra; o descalabro econômico do país e a Guerra Civil Branca.

Victor Serge relata a sabotagem nas cidades. Por 4 longos meses, a tentativa de derrubar o governo bolchevique foi permanente.

Quando os vermelhos vitoriosos entraram nos edifícios da Duma municipal de Moscou, só encontraram destroços. Os processos serviam para bloquear as janelas. Os armários e as mesas estavam vazios. As máquinas de escrever não funcionavam. Os funcionários da cidade - 16 mil homens —, estavam em greve. (...) Por um lado, a greve de todos os funcionários, sem exceção, médicos, professores, engenheiros, o boicote dos empregados, a sabotagem praticada pelos 
novos funcionários e, por outro lado, a necessidade de pagar aos operários seu salário normal, a necessidade de alimentar dezenas de milhares de refugiados e de prover, a qualquer custo, a manutenção dos serviços de abastecimento de água, esgoto, de bondes, matadouros, gás, eletricidade —, esse era o problema com que se defrontaram subitamente, os trabalhadores e militantes(...) Em Petrogrado a situação era semelhante e os efeitos da sabotagem se estendiam nas grandes administrações do Estado.... ${ }^{189}$

Os bancos estavam vazios. As repartições públicas sequer possuíam açúcar para o chá. Mesmo os funcionários que compareciam aos trabalhos, estes se recusavam ao serviço. No Ministério das Relações Exteriores, Trotsky não encontrou nenhum funcionário, nem mesmo para abrir as portas. Serge avalia que talvez o grande perigo relacionado a sabotagem tenha sido a vodka. Trens carregados da bebida eram distribuídos aos bolcheviques, militantes e operários revolucionários. O álcool minava a revolução por dentro. As medidas adotadas são enérgicas: fuzilamentos, destruição da bebida e prisões. Trotsky faz um discurso tenso no início de dezembro. Ao final, o líder do Exército Vermelho proclama que "A cada dia de bebedeira mais se aproxima a vitória ( da contra-revolução) e nos leva de volta à escravidão". Uma semana depois a vodka sumira.

Em Janeiro de 1918 a revolução soviética assinava a Paz. O Tratado de BrestLitovsk. Trotsky sonhava com uma união entre os operários alemães e russos. Uma revolução mundial socialista. Fracassou nas previsões. Lênin denominou o acordo de Paz Separada e Anexionista. A “Paz Infeliz”. Infeliz pela suspensão soviética do apoio a revolução permanente e também pela imensa perda territorial. As potências centrais tiraram da Rússia soviética uma grande faixa de terra do Báltico ao mar Negro. O corredor passava por Finlândia, Polônia, Bielorússia ( país da cidade de Brest-Litovsk), Lituânia, Letônia e Estônia e se alargava ao sul, tomando toda a Ucrânia do país infeliz. Duas décadas e meia depois, Stálin anexou boa parte das terras novamente.

Outra crença equivocada dos bolcheviques se relacionava a Paz. Uma miríade de contra-revolucionários e a burguesia de dezenas de países lutaram para derrubar o socialismo soviético. Antigas tropas leais ao Tzar, soldados contrários ao socialismo, socialistas revolucionários, mencheviques e anarquistas organizaram o Exército Branco

\footnotetext{
${ }^{189}$ SERGE, Victor. O ano I da revolução russa. Editora Boitempo. São Paulo. 2007. Pág. 121
} 
ainda em finais de novembro de 1917. Depois de Brest-Litovsk, potências como os Estados Unidos, a Inglaterra, a França, o Japão e mesmo soldados alemães e do Império Austro-húngaro enviaram tropas, armas e capitais para destruir o espectro comunista. Uma longa e cruenta batalha que dizimou quase 3 milhões de pessoas e prolongou-se por quase 5 anos. Coube a Trotsky comandar o Exército Vermelho e seu efetivo de 5 milhões de soldados ( formados em sua maioria por camponeses e operários). Após a vitória sofrida dos comunistas, nascia a União das Repúblicas Socialistas Soviéticas.

No total, o antigo Império enfrentou 8 anos seguidos de guerra. A produção agropecuária retrocedeu aos níveis do século XII. A estrutura física do país estava destruída: portos, estradas, ferrovias, eletricidade e prédios em geral. Pouco menos de 6 milhões de mortos ( $4 \%$ da população). Em torno de 20 milhões de cidadãos designados como soldados. A Fome, o terceiro cavaleiro do apocalipse tomava conta dos campos russos. Cabe a revolta de Lisa Bolkonskaya em Guerra e Paz contra a inutilidade dos conflitos: ${ }^{190}$

- Sabe, o meu marido vai abandonar-me - prosseguiu ela no mesmo tom, dirigindo-se a um general. - Vai procurar a morte. Digame: para que serve esta maldita guerra? - disse ao príncipe Vassili, e, sem esperar qualquer resposta...

Terminada a longa luta comunista, agora nascia o grande desafio: organizar a primeira economia socialista da história, num país que antes da Grande Guerra era o menos viável para colocar em prática os ideais socialistas e depois da Guerra Civil Branca tratava-se do último e pior lugar para se viver no mundo. Tarefa esta que Lênin não fugirá:

(...) 'Quem não trabalha não come' — como levar isto à prática? É claro como a luz do dia que para levar isto à prática é necessário, primeiro, o monopólio estatal dos cereais, isto é, a proibição absoluta de todo o comércio privado de cereais, a entrega obrigatória ao Estado de todos os excedentes de cereais a preço fixo, a proibição absoluta a quem quer que seja de reter e ocultar os excedentes de cereais. Segundo, para isto é necessário um registro rigoroso de todos os excedentes de cereais e o envio irrepreensivelmente correto dos cereais dos lugares onde os há em excesso para os lugares onde são

\footnotetext{
${ }^{190}$ TOLSTOI, Leon. Guerra e Paz. Cosac-Naify. São Paulo. 2009. Pág. 39
} 
insuficientes, juntamente com a acumulação de reservas para o consumo, a elaboração e a sementeira. Terceiro, para isto é necessário uma distribuição dos cereais correta, justa, que não dê nenhuns privilégios nem vantagens aos ricos, entre todos os cidadãos do Estado, sob o controlo do Estado operário, proletário.

Basta refletir minimamente acerca destas condições da vitória sobre a fome para compreender a profundíssima estupidez dos desprezíveis charlatães do anarquismo, que negam a necessidade do poder de Estado (implacavelmente severo com a burguesia, implacavelmente firme em relação aos desorganizadores do poder) para a transição do capitalismo para o comunismo, para a libertação dos trabalhadores de todo o jugo e de toda a exploração. Precisamente agora, quando a nossa revolução abordou em pleno, de maneira concreta e prática - e nisto consiste o seu imenso mérito - as tarefas da realização do socialismo, precisamente agora, e exatamente na questão do que é mais importante, na questão dos cereais, vê-se com a maior clareza a necessidade de um férreo poder revolucionário, da ditadura do proletariado, da organização da recolha de produtos alimentares, do seu transporte e da sua distribuição numa escala de massas, nacional, tendo em conta as necessidades de dezenas e centenas de milhões de pessoas, calculando as condições e os resultados da produção com um e com muitos anos de antecedência (pois há anos de más colheitas, são necessários trabalhos de melhoria dos solos para que aumente a colheita de cereais, o que requer um trabalho de muitos anos, etc). ${ }^{191}$

Todos os elementos da economia soviética apareciam ali na carta aos operários de 1918. Centralização e monopólios estatais. Controle da produção e distribuição dos excedentes para combater a fome e as desigualdades. A importância do Estado e da ditadura do proletariado para a transição do capitalismo para o socialismo e deste para o comunismo. O conceito de planejamento estratégico e a longo prazo da produção. Enquanto isso, o capitalismo vivia sobre outro espectro, o da mão invisível e outra crença atávica: a de que a oferta cria sua demanda própria.

\footnotetext{
${ }^{191}$ LÊNIN. Escrito: a 22 de maio de 1918. Primeira Edição: Pravda, n 101, de 24 de Maio de 1918. Fonte: Obras Escolhidas em Três Tomos, 1978, t2, p 618-623, Edições Avante! — Lisboa, Edições Progresso - Moscovo. HTML: Fernando A. S. Araújo, março 2009.
} 
Marx se equivocou ao afirmar que o espectro rondava apenas a Europa, afinal o comunismo derramava sua insurreição sobre os corações e mentes de Kamchatka à Patagônia.

\section{4. Quarto Cavaleiro: A morte e a Crise de 1929}

Chegamos ao quarto cavaleiro do apocalipse, a Morte. Num cavalo amareloesverdeado, a cor dos defuntos, a História nos traz a maior crise econômico-financeira do capitalismo: a queda da bolsa de Nova York. Curiosamente, ela ocorreu na última terça-feira de outubro, dois dias antes do "feriado inglês" ( Halloween) ${ }^{192}$, o dia das bruxas norte-americano. Porém, não havia doces nem travessuras.

Galbraith questiona a veracidade das histórias sobre os dias que se seguiram à "terça negra", nos quais:

Dizia-se que os empregados de hotel em Nova York perguntavam aos clientes se desejavam um quarto para dormir ou para pular. Dois homens saltaram, de mãos dadas, de um andar do Ritz — tinham uma conta conjunta. ${ }^{193}$

Há um certo consenso e uma razoável simplificação em se explicar a Crise de 1929 pela superprodução. Suas raízes, entretanto, estão fincadas bem antes. A "paz punitiva" de Versalhes é uma delas. Os Impérios do centro foram obrigados a pagar vultosas dívidas. A Alemanha, por exemplo, teria de desembolsar 132 milhões de marcos ouro ( atualizados, estes valores seriam em torno de US\$ 250 bilhões) para os bancos norte-americanos até 1929 . As vésperas da crise, pouco mais de $15 \%$ desse valor havia sido pago. O esfacelado Império Austro-Húngaro e a Turquia ( também desagregada) pouco pagaram das suas indenizações de guerra. Eram dívidas de longo prazo que seriam pagas com empréstimos de curto prazo. A conta nunca fechava. Se num primeiro momento as nações endividadas procuravam quitar seus compromissos com políticas emissionistas ( daí a hiperinflação alemã do início dos anos 20), nos anos

\footnotetext{
${ }^{192}$ Em 1845, milhões de irlandeses migraram do país natal para os EUA, fugindo da grande crise da Fome. Anos depois aparecem relatos de uma festividade pagã comemorada na véspera do Dia de todos os Santos ( $1^{\circ}$ de Novembro). Seu nome original era Hallow ( forma antiga de se designar 'santo') e Eve, véspera. A aglutinação deu Halloween. Nos anos 20 começou a tradição do "doce ou travessuras" e das abóboras. No pós 'crash de 29', a violência era por vezes incontida. As fantasias tem sua história ligada a famosa transmissão de Orson Welles para a Guerra dos Mundos.

${ }^{193}$ John Kenneth GALBRAITH em seu livro La crise économique de 1929, deitou por terra essa lenda, constatando que ela não tem base estatística que a comprove. Houve suicídios, sem dúvida, em 1929, mas em média menos do que durante os anos entre 1930 e 1933. Apud: GAZIER, Bernard. A crise de 1929. L\&PM. Rio Grande do Sul. Pág. 18.
} 
loucos ( 1925-1929) a ideia genial era seu inverso: cortes substanciais de gastos públicos e redução do capital circulante. ${ }^{194}$ Economistas são muito criativos.

Outro fator foi a especulação financeira. Desde 1928 as Bolsas de Valores e, em especial, a maior de todas: a de Nova York. Elas expandiram descontroladamente empréstimos do tipo "call loans". Investidores compravam ações pagando pequena parte do preço. O valor faltante era fornecido por corretores. Estes, por sua vez, emprestavam diariamente as quantias dos bancos americanos ( prática denominada de 'on call”). Como a procura pelas ações não parava de crescer, os preços seguiam a mesma lógica. O lucro na venda das ações bastava para investidores e corretores. Para os bancos, os empréstimos sucessivos garantiam a margem de lucro. Todos ganhavam no abismo existente entre o desenvolvimento econômico e os papéis voláteis. ${ }^{195}$

Em 31 de dezembro de 1927, as "call loans" totalizavam US\$ 4 bilhões. Um ano e dez meses depois atingiam US\$ 8,5 bilhões ( $5 \%$ do PIB americano de então). No último dia de 1929 voltaram aos US\$ 4 bilhões.

Bernard Gazier nos explica outro motivo da crise:

... O problema monetário era o seguinte em 1918: depois de anos de cursos forçados, de controle de capitais e de penúrias inflacionistas, como voltar à liberdade de comércio? O mecanismo internacional que vigorava antes de 1914 era o do padrão-ouro. Este ligava as diferentes moedas entre si através de seu peso em ouro definido de forma fixa; as moedas eram portanto convertíveis em ouro, e o metal, que circulava a público, podia ser importado e exportado livremente. A Conferência Internacional de Gênova, em 1922, sanciona um sistema diferente, o do padrão de câmbio-ouro (gold exchange standard), estabelecido pouco a pouco a partir de 1918. As necessidades de reconstrução e retomada do comércio internacional levaram a uma conservação da referência em ouro; porém, devido à sua raridade e à sua distribuição desigual, a uma referência em segundo grau: a moeda de cada país não mais ficava diretamente ligada ao ouro, mas a uma moeda fundamental, definida e convertível em ouro. Os créditos em países de moeda "central", como

\footnotetext{
194 “ Diante dos desequilíbrios das trocas externas e das eventuais ofensivas monetárias, a deflação em sentido estrito consiste em restringir a multiplicação dos meios circulantes com rigorosas economias orçamentárias, reduções autoritárias de preços ou de salários e controle do crédito. Espera-se com isso pressionar o nível dos preços internos do país e assim restaurar sua competitividade: é melhor vender ao exterior, resistir aos produtos estrangeiros, atrair capitais" ( GAZIER, Bernard. A crise de 1929. L\&PM. Rio Grande do Sul. Pág.30)

${ }^{195}$ Exemplificando melhor: O investidor comprava as ações da GM pagando US\$ 100 o lote. Do capital próprio, ele pagava US\$ 10. Os outros US\$ 90 vinham de empréstimos dos corretores. Estes, emprestavam diariamente dos bancos. Suponha-se que as ações da GM subissem para US\$ 130 em poucos dias. O investidor recebia US\$13, o corretor US\$117. Os bancos? Um novo empréstimo do corretor, agora de US\$120 bancava a dívida anterior.
} 
se dizia, as reservas cambiais, substituem o ouro em quase todos os países. Houve duas moedas centrais, a libra esterlina e o dólar, que alargam a base das trocas internacionais. $\mathrm{O}$ ouro, em si, não circula mais e adquire um papel de reserva nacional ao lado das reservas cambiais. Podemos perceber a vulnerabilidade desse sistema bipolar que confirma o enfraquecimento britânico e a ascensão ainda hesitante dos Estados Unidos: a regulação internacional depende do controle e da coordenação de dois centros e da confiança dos demais países. ${ }^{196}$

Acentua-se dessa forma uma característica das vésperas da Primeira Guerra: a ascensão econômica norte-americana e o declínio europeu. A Inglaterra não só perdera a liderança industrial ( isto já no fim do século XIX); seu poderio econômico fora suplantado pelos Estados Unidos e pior, a padrão-ouro e depois a libra esterlina cada vez mais eram absorvidos pela força do dólar americano.

Podemos também citar a crise das commodities ${ }^{197}$. A Grande Guerra trouxe o choque adverso nos países periféricos como o Brasil. Primeiro com a retração da produção de bens primários nos países centrais e a crise de abastecimento num continente em guerra. Depois, pelas necessidades internas de bens de consumo não atendidas pelo redirecionamento da produção europeia para os esforços de guerra; abriu-se uma nova fronteira de crescimento econômico aos países novos: aumentar sua produção de matéria-prima para abastecer a Europa e produzir bens de consumo para abastecê-los - além, é claro, de suprir as necessidades internas com a queda brutal nas importações.

No Brasil, entre 1914 e 1926, as safras de café são ampliadas. As áreas cultivadas aumentam e os progressos técnicos ampliam a produtividade. Essa condição se repete em vários países periféricos. Porém, de 1926 a 1930, a demanda declina acentuadamente. Na República do Kaphet ( como denominava satiricamente nosso país o escritor Lima Barreto), as quedas no valor das exportações passaram dos $60 \%$. Seja pelo declínio dos preços internacionais ou pela redução da demanda.

Uma nova forma de produção surgia no campo. Mecanizada, com redução drástica do elemento humano ( em 1930, 30\% dos norte-americanos trabalhavam na zona rural; meio século depois essa porcentagem era de $3 \%$ ). O mercado financeiro

\footnotetext{
${ }^{196}$ GAZIER, Bernard. A crise de 1929. L\&PM. Rio Grande do Sul. 2010. Pág. 18-19.

${ }^{197}$ A Chicago Board and Trade (CBOT) nasceu no século XIX. Trata-se de uma Bolsa que comercializa ações de matérias-primas ou bens primários. O nome 'commodities' é originário do inglês. Em verdade, passou a ser utilizado no Brasil a partir dos anos 90 , substituindo a antiga denominação de matérias-primas, na maioria das vezes do setor agrário, pecuário e de recursos minerais.
} 
deitava suas garras sobre a produção agropecuária. A destruição do velho Estados Unidos sangrou feridas pelo país. John Steinbeck talvez tenha sido seu maior retratista:

Os estados ocidentais inquietavam-se sob os efeitos da metamorfose incipiente. Texas e Oklahoma, Kansas e Arkansas, Novo México, Arizona. Califórnia. Uma família isolada mudava-se de suas terras. $\mathrm{O}$ pai pedira dinheiro emprestado ao banco e agora o banco queria as terras. A companhia das terras - que é o banco, quando ocupa essas terras - quer tratores, em vez de pequenas famílias, nas terras. Um trator é mau? A força que produz os profundos sulcos na terra não presta? Se esse trator fosse nosso, não meu, nosso, prestaria. Se esse trator produzisse os sulcos em nossa própria terra, prestaria na certa. Não nas minhas terras, nas nossas. Então, sim, a gente gostaria do trator, gostaria dele como gostava das terras quando ainda eram nossas. Mas esse trator faz duas coisas diferentes: traça sulcos nas terras e expulsa-nos delas. Não há quase diferença entre esse trator e um tanque. Ambos expulsam os homens que lhes barram o caminho, intimidando-os, ferindo-os. Há que pensar sobre isto. Um homem, uma família, expulsos de suas terras, esse veículo enferrujado arrastando-se e rangendo pela estrada rumo ao Oeste. Perdi as minhas terras; um trator, um só, arrebatou-as. Estou sozinho e apavorado. E uma família pernoita numa vala e outra família chega e as tendas surgem... ${ }^{198}$

Some-se a estes fatores a superprodução citada inicialmente. As políticas protecionistas na década de 20 permitiram aos países centrais um acréscimo produtivo. Praticamente em todos os setores da economia capitalista as novas tecnologias redundavam em ganhos de produtividade. Por outro lado, a ciclo de investimentos em capitais fixos do final dos anos 10 e início da década seguinte estavam amortizados. O resultado foi uma produção em escala desacompanhada dos aumentos de renda ou de mercado. O Brasil produzia 30\% mais café em 1929 do que em 1919. A produção mundial de algodão não parava de crescer, seja pela ampliação das áreas plantadas ou por meio das novas técnicas de plantio e colheita. O trator e as dívidas bancárias engoliam as famílias, como narrou John Steinbeck em “As vinhas da ira”. Mais algodão com menos consumo, afinal os fios sintéticos eram substitutos ideais em alguns casos. 
$\mathrm{Na}$ indústria têxtil havia até fatores ligados às transformações culturais. Uma senhora casadoura da era vitoriana, dos fins do século XIX, precisava de metros e metros de pano para cobrir suas vergonhas; enquanto a sensualidade das dançarinas de rumba e de tango ou a alegria contagiante do charleston dos anos 20 necessitavam de poucas peças de roupa.

A indústria automobilística norte-americana e suas necessidades de matériasprimas abundantes e mercados ilimitados crescia vertiginosamente: em 1927 foram produzidos 6,8 milhões de carros no país; na média de 1929 ( até setembro) as fábricas dos senhores Ford e Chrysler - que comprara a empresa dos irmãos Dodge no ano anterior -, além da GM e outras menores, produziram em média 612 mil carros por mês. Tal número só foi batido na década de 70 novamente. No pós-crise, saíam 460 mil carros por mês das fábricas, uma redução de $25 \%$ no mercado. A oferta não criou sua própria demanda.

Arranha-céus se espalharam pelo país. Nova York, a capital financeira do mundo no fim dos anos 20, erguia torres cada vez mais altas. As tecnologias nascidas na segunda metade do século XIX como o aço, a eletricidade e o concreto, além é claro de uma engenharia de construções e uma arquitetura da opulência fizeram as disputas empresariais buscar as alturas. O Chrysler Building foi erguido em 20 meses e atingiu 319 metros. Dois meses antes de sua inauguração em Maio de 1930, iniciavam-se as obras do Empire State Building. Em apenas 13 meses os operários levantaram a maior torre novaiorquina até os anos 70, com 381 metros. Não contavam com a Depressão. No primeiro ano de seu funcionamento, o prédio conseguiu alugar cerca de $20 \%$ de suas salas. Ganhou a alcunha de Empty ( vazio) State Building.

As consequências para a economia mundial da crise de 1929 são terríveis. Nas cidades, o desemprego tomou conta das cidades. Historiadores falam de 12 milhões de desempregados nos Estados Unidos. Levando-se em conta que a população ativa do país em 1929 era de 60 milhões de habitantes e destes, cerca de 18 milhões eram trabalhadores do campo, tínhamos que 1 em cada 3 moradores das cidades estava desempregado. No mercado financeiro a concentração bancária foi favorecida. Em 1926 existiam aproximadamente 29.000 bancos na América, 5 anos depois restavam 12.000 instituições e entre os que restaram, cerca de $50 \%$ do capital estava na mão de duzentas instituições.

Por ser uma economia global e interligada, a crise se espalhou rapidamente para todo o mundo. Os socialistas mataram o capitalismo diversas vezes em suas previsões 
nos anos 30. E o comparativo da década permitia isso, afinal, se adotarmos um parâmetro de 100 para a economia norte-americana em 1930, em 1939 ela atingia 132. O Japão pulara de 100 para 168 e a Inglaterra de 100 para 117. Enquanto isso, segundo Maurice Crouzet ${ }^{199}$ a União Soviética saltava de 100 para 474. Para enfrentar a crise era necessário buscar uma nova direção keynesiana. Para derrotar o medo do fantasma comunista, o soldado era o terror nazi-fascista. Por terras brasileiras a solução tratava-se de queimar o café e amarrar o cavalo gaúcho no Catete, defenestrando a velha oligarquia do café-com-leite. E depois tanto a direita integralista, quanto os operários simpáticos ao socialismo, bem como o comunista-tenente Luis Carlos Prestes.

Ao americano médio nem o álcool consolava, afinal de janeiro de 1920 a março de 1933 vigorou a $18^{\mathrm{a}}$ Emenda Constitucional. Numa aliança entre igrejas batistas, políticos conservadores e Klu Klux Klan proibira-se a bebida. O falso moralismo norteamericano fazia vistas grossas para a falsificação, o contrabando e o tráfico comandado por Al Capone e colegas. Lamento e depressão autorizados, só o do Blues de Robert Johnson. Considerado por muitos o maior compositor do Blues da história, o "Pobre Bob" criou cerca de 40 músicas entre 1929 e 1937. Lamentos de amor e dor numa sociedade racista e em alto grau de desagregação. A lenda é que Johnson fez um pacto com o demônio para produzir a música inigualável. Buscou ajuda em Eleguá, o rei dos caminhos da felicidade na religião iorubá ( o Santo Antonio de Pádua na Santeria). Em “Crossroad Blues”, Johnson suplica ao senhor:

... Eu desci até a encruzilhada

Dobrei meus joelhos

Supliquei ao senhor,

tem misericórdia do pobre Bob

Eu acredito que minha alma

É a do pobre Bob afundando

Olhei para o oeste e leste dessa encruzilhada

E para meu desgosto não tinha ninguém...

A desolação de uma nação perdida. A alma sem misericórdia dos norteamericanos. Uma encruzilhada no Destino Manifesto.

Fecha-se o ciclo do contexto internacional. O imperialismo, constituído no final do século XIX, política típica da segunda revolução industrial, era do capitalismo

\footnotetext{
${ }^{199}$ CROUZET, Maurice. História geral das civilizações. Volume 15. A época contemporânea. O declínio da Europa. O mundo Soviético. Bertrand Brasil. Rio de Janeiro. 1996.
} 
monopolista-financeiro, partilhou-se a periferia do sistema-mundo e, nas palavras do Manifesto Comunista:

Por meio de sua exploração do mercado mundial, a burguesia deu um caráter cosmopolita à produção e ao consumo em todos os países. Para desespero dos reacionários, retirou da indústria sua base nacional. As velhas indústrias nacionais foram destruídas ou estão se destruindo dia a dia. São suplantadas por novas indústrias, cuja introdução se torna uma questão de vida e morte para todas as nações civilizadas, por indústrias que não empregam matérias-primas autóctones, mas matérias-primas vindas das zonas mais remotas; indústrias cujos produtos se consomem não somente no próprio país, mas em todas as partes do globo. Em lugar das antigas necessidades, satisfeitas pela produção nacional, encontramos novas necessidades que requerem para sua satisfação os produtos das regiões mais longínquas e dos climas mais diversos. Em lugar do antigo isolamento local e da autosuficiência das nações, desenvolvem-se, em todas as direções, um intercâmbio e uma interdependência universais. E isso tanto na produção material quanto na intelectual. As criações intelectuais de uma nação tornam-se propriedade comum de todas. A estreiteza e o exclusivismo nacionais tornam-se cada vez mais impossíveis e das numerosas literaturas nacionais e locais surge a literatura universal. ${ }^{200}$

Uma sociedade burguesa que levou à Guerra e procurou defender as bandeiras nacionais. Burguesia esta que se viu ameaçada pelo medo da expansão socialista proveniente da vitória russa de 1917. Capitalismo em estado de choque com a bolsa de valores à bancarrota em 1929. Entender um pouco mais desses ciclos políticos e econômicos e as relações dos mesmos com a economia da República Velha será o tema do capítulo a seguir.

\footnotetext{
${ }^{200}$ MARX, Karl \& ENGELS, Friederich. O manifesto comunista. São Paulo. Instituto José Luis e Rosa Sundermann. 2003. Pág. 29
} 


\section{CAPÍTULO 7 - ECONOMIA NA REPÚBLICA VELHA}

\subsection{Ciclos Olímpicos e Econômicos}

Pierre de Frédy, ou Barão de Coubertin conseguiu reunir 13 países, 241 atletas em 43 competições distintas no ano de 1896 em Atenas na Grécia. Nasciam os Jogos Olímpicos Modernos. Em verdade, desde o século XVII, diversos entusiastas das atividades físicas tentaram organizar jogos entre súditos, cidadãos, ou mesmo nações. Entre 1622 e 1642, anualmente, o advogado inglês Robert Dover, com a devida chancela do Rei James, organizou o "Costwold Olimpick Games". Corridas, lutas, competições equestres. A Revolução Inglesa acabou com a festa regional. Outra revolução, a Francesa, teve sua experiência esportiva entre 1796 e 1798, “ L'Olympiade de la République". A busca da perfeição nos critérios técnicos fez surgir o sistema métrico francês. A segunda metade do século XIX contou com vários eventos em diversos países europeus. Foi nesse período também em que surgiram boa parte dos esportes coletivos atuais como o futebol, o basquete e o voleibol. Mas coube ao sonhador e inocente Coubertin a organização de um evento esportivo internacional. Para ele, na vida e no esporte:

"O importante na vida não é o triunfo, mas a luta, o essencial não é ter vencido, mas ter lutado bem." 201

Sua mente idílica acreditava ainda que os jogos serviriam à Paz Universal ${ }^{202}$. Bastou meio século para o mundo assistir duas guerras jamais vistas. E entre elas, a cada quatriênio, atletas se congraçavam como se nada ocorresse ( com exceção de 1916, 1940 e 1944, em plenas Primeira e Segunda Guerras, quando os jogos foram suspensos). Alemanha, Áustria, Hungria e Turquia foram punidas em 1920 por desrespeitar a paz: não puderam participar dos jogos. Mas em 1935, a mesma Alemanha ( agora governada por Hitler e os nazistas) ganha dois presentes do Comitê Olímpico Internacional: a organização dos jogos de verão do ano seguinte em Berlim e na cidade

\footnotetext{
${ }^{201}$ Apud: Hill, Christopher R. Olympic Politics. Manchester University Press. Inglaterra. 1996. Pág.7. Trata-se de um jornalista homônimo do historiador do "Eleito de Deus", ambos britânicos.

${ }^{202}$ Totalmente amadorísticos e bairristas, as Olimpíadas só adquiriram caráter profissional a partir da edição de 1924. Poucos países participavam. As competições se arrastavam por meses ( a Olimpíada de Paris em 1900 foi de março até outubro). Os atletas ou eram militares, ou estudantes universitários ou curiosos amadores. Nas sete primeiras edições, 6 foram realizadas na Europa, sendo duas delas em Paris. Em quase todas as edições, os atletas norte-americanos dominaram o quadro de medalhas e a União Soviética só ganharia a primeira medalha em 1952. Saint Louis em 1904 inventou os infames "Jogos Antropológicos" com torneios de pigmeus africanos contra índios da Patagônia. O idealizador dos 'jogos' racistas e xenofóbicos era J.E. Sullivan. Seu objetivo era provar a superioridade da civilização branca ocidental. Corridas de muçulmanos, turcos, aborígenes das Filipinas, entre outros, estavam na programação.
} 
de Garmisch-Partenkirchen, localizada na Baviera, região da expansão nazista, os jogos de inverno.

A bandeira olímpica apresenta 5 círculos concêntricos e interligados. Representa os cinco continentes: Europa na cor azul, África preta e América vermelha - estas na parte alta —, além da Ásia na cor amarela e Oceania verde, nos círculos abaixo. Foi hasteada pela primeira vez na Antuérpia, menos de dois anos após o fim da Grande Guerra. São vários os símbolos circulares nesses jogos, assim como temos dezenas de interpretações econômicas e a prática comercial que encaram a produção de bens escassos para um consumo crescente de forma cíclica.

Segundo Hobsbawm:

... as operações de uma economia capitalista jamais são suaves, e flutuações variadas, muitas vezes severas, fazem parte integral dessa forma de reger os assuntos do mundo. O chamado 'ciclo do comércio, de expansão, de queda', era conhecido pelo homem de negócios do século XIX... ${ }^{203}$

Um ciclo olímpico repete-se a cada quatro anos. Entretanto, a vida de um atleta não se limita ao período citado. Há todo um período inicial em que a somatória de investimentos em preparação física, amadurecimento corporal, competições variadas, alimentação regrada, recuperação psicológica, entre outros, são investidos no atleta em potencial. Os frutos desse trabalho aparecem (em geral) quando este ultrapassa os 20 anos de idade.

Alguns destes conseguem obter medalhas e entrar para a história esportiva numa edição, como a ginasta romena Nadia Comãneci em 1976. Outros, como o imbatível boxeador cubano Teófilo Stevenson Lawrence, por 3 ciclos entre 1972 e 1980. Observe-se que o ciclo de preparação de um atleta pode superar e muito os quatro anos e mesmo durante o quatriênio entre uma Olimpíada e outra, os atletas disputam dezenas de campeonatos, torneios, sejam eles nacionais ou internacionais.

Como na economia, os ciclos esportivos se inter-relacionam, se sobrepõe, tem durações distintas. Portanto, para cada novo atleta há um longo ciclo de preparação. De forma desigual alguns atingem o ápice e conquistam glórias desportivas. Poucos prolongam o ciclo virtuoso por vários anos. Vem o declínio do rendimento e o fim do

\footnotetext{
${ }^{203}$ HOBSBAWM, Eric. A era dos extremos. Companhia das Letras. São Paulo. 1995. Pág. 91
} 
ciclo. Velhos heróis serão substituídos por novos vencedores. Os atletas repetem a mais tradicional explicação para o que seriam os ciclos econômicos, segundo a escola monetarista:

Os ciclos de negócios são um tipo de flutuação encontrada no agregado das atividades econômicas dos países que organizam o seu trabalho por meio, principalmente, de empresas privadas. Um ciclo consiste em fase de expansões que ocorrem num certo período de tempo e concomitantemente em muitas atividades econômicas, seguidas por fases, em geral semelhantes, de recessões, contrações e retomadas que se fundem em expansão na fase do ciclo seguinte; esta sequência de mudanças é recorrente, mas não periódica. Cada ciclo pode ter duração de mais de um ano, até dez ou doze anos; eles não são divisíveis em ciclos mais curtos de semelhante formação e características de amplitudes aproximadamente parecidas" ${ }^{204}$ ( tradução nossa)

A variação e alternância entre os ciclos não é uma ciência exata. As flutuações econômicas, as políticas restritivas ou expansivas adotadas pelos governos, a maior ou menor capacidade de absorção dos investimentos em capital fixo não são rígidas, nem milimetricamente marcadas.

Para as elites políticas e econômicas brasileiras os ciclos se sucediam sem que eles perdessem seu poder ou capital ( a maioria deles pelo menos, afinal as diversas intervenções no mercado durante a República Velha tiveram como objetivo central a socialização dos prejuízos, como diria Celso Furtado). Schumpeter esclarece que independente da duração e da inter-relação entre os ciclos, o certo é que eles acontecem. Os marxistas, como afirma Hobsbawm, ao observar o ciclo virtuoso soviético paralelamente a brutal recessão pós 1929, passaram a ter certeza de que aquele era o último ciclo do capitalismo:

No passado, ondas e ciclos, longos, médios e curtos, tinham sido aceitos por homens de negócios e economistas mais ou menos como os fazendeiros aceitam o clima, que também tem seus altos e baixos. Nada se podia fazer a respeito; criavam oportunidades ou problemas, podiam trazer a prosperidade ou a bancarrota a indivíduos ou indústrias, mas só os socialistas que, como Karl Marx, acreditavam que o ciclo fazia parte de um processo pelo qual o

\footnotetext{
${ }^{204}$ BURNS, Arthut Frank \& MITCHELL, Wesley Clair. Measuring Business Cycles. New York, New York: National Bureau of Economic Research, 1946. Pág. 3
} 
capitalismo gerava o que acabariam por se revelar contradições internas insuperáveis, achavam que elas punham em risco a existência do sistema econômico como tal. Esperava-se que a economia mundial continuasse crescendo e avançando, como havia claramente feito, com exceções de súbitas e breves catástrofes de depressões cíclicas, por mais de um século. O que parecia ser novo na recente situação era que, provavelmente pela primeira e até ali única vez na história do capitalismo, suas flutuações apresentavam perigo para o sistema. E mais: em importantes aspectos, a curva secular da subida parecia interromper-se... ${ }^{205}$

Portanto, há um ciclo longo, permeado de ciclos curtos, períodos a-cíclicos, freadas bruscas e retomadas. Nada é rígido, tudo é fluido como a economia. A rigidez dos ciclos e a disputa entre qual a interpretação mais correta para a análise econômica empobrecem o conhecimento do passado. Seja o ciclo Kitchin, o ciclo Juglar, o de Kuznets, o de Kondratieff ou mesmo as análises de Schumpeter. Há consenso de que todas as ondas econômicas são dotadas de 4 fases: o "boom" econômico, a recessão, a depressão e a recuperação.

Joseph Kitchin detectou os ciclos de demandas por bens duráveis nos anos 20 . Denominados de ciclos curtos, eles prolongam-se por 3 a 4 anos (ou 40 meses). Os empresários percebem a crescente demanda em setores específicos dos bens duráveis, investem maciçamente em ganhos de produtividade e aumentam consideravelmente a produção. O mercado, inundado pela superprodução de mercadorias, entre em declínio. Lembra o quatriênio olímpico. Detectado o atleta com potencial, este recebe investimentos maciços, o rendimento cresce paulatinamente e tem seu ápice na competição e, em muitos casos, esgota-se o ciclo e parte-se para um novo investimento. Coincidentemente nos anos 20, a economia brasileira expandia seu mercado interno.

Outro autor foi Clement Juglar, economista francês, que na segunda metade do século XIX, observou a existência de ciclos médios de 7 a 11 anos. Tais ciclos seriam relacionados o direcionamento dos investimentos gerais da economia para a indústria de bens de capitais. O denominado capital fixo. Podemos observar com facilidade a presença dos ciclos de Juglar na economia brasileira, desde pelo menos a República Velha.

Simon Kuznets desenvolveu nos anos 30 uma teoria de ciclos demográficos. Países que passaram por grandes alterações de população, seja pela queda da

\footnotetext{
${ }^{205}$ HOBSBAWM, Eric. A era dos extremos. Companhia das Letras. São Paulo. 1995. Pág. 92
} 
mortalidade típica das revoluções urbano-sanitárias, ou pela entrada massiva de imigrantes. O exponencial crescimento demográfico vem acompanhado de investimentos vultosos em infra-estrutura, com sua fase inicial de "boom" e a posterior recessão relacionada aos gastos públicos. A última década do século XIX e a primeira do XX no Brasil poderiam ser interpretadas por meio desse ciclo. Não só tivemos a explosão demográfica, como a entrada maciça de imigrantes.

Nicolai Kondratieff é o mais importante de todos os pensadores econômicos de ciclos. Segundo o soviético, seriam três as ondas de desenvolvimento no capitalismo: expansão, estancamento e recessão. Alguns economistas adicionam uma fase de colapso após a expansão. Duram entre 47 a 60 anos. Para Kondratieff:

(...) os ciclos longos no sistema capitalista resultam de sólidos investimentos ou de sua depreciação em infra-estrutura, como: ferrovias, portos, canais, indústria, saneamento básico, eletrificação, construção civil, etc. Nestes ciclos a fase de expansão é caracterizada por superinvestimentos em bens de capital e na fase da depressão, por um processo de depreciação. Os ciclos para ele, representam épocas do desenvolvimento do capitalismo. (...) Ele queria provar a existência dos ciclos, a partir de evidências empíricas presentes e expressas na história da economia mundial. Com esse propósito ele catalogou os dados de quase todos os países, principalmente da França, da Alemanha, dos Estados Unidos e Inglaterra, demonstrando que os mecanismos e leis que condicionam os ciclos longos são provenientes de: modificações técnicas; guerras e revoluções; assimilação de novos países dentro da economia mundial e flutuações na produção de ouro. $^{206}$

Em seu estudo original dos anos 20, Kondratieff propôs a existência de 3 longos ciclos até então no capitalismo. O último deles com início em 1896, com o fím da recessão mundial e retomada da expansão Imperialista. Coincidentemente no Brasil a oligarquia do café-com-leite passava a ter o predomínio definitivo. E na Grécia, no mesmo ano de 1896, o barão de Coubertin inaugurava os Jogos Olímpicos da era moderna.

\footnotetext{
${ }^{206}$ ABREU, Yolanda Vieira de \& SILVA, Helke Hernandes Raposo. Ignácio Rangel e os ciclos de Kondratieff. Palmas. Tocantins. 2009. Pág. 17
} 
Por último temos a tese liberal de Joseph Schumpeter elaborada nos anos 30. Para ele, os ciclos longos resultam da conjugação ou da combinação de inovações tecnológicas, permitindo a formação de um setor líder da economia. É este setor que, antes de ser hegemônico, produz e transforma o capitalismo por meio de uma avalanche de destruições criativas e revolucionárias que alavancam a economia como um todo. $\mathrm{O}$ setor líder no Brasil, infelizmente por um bom tempo, foi o café.

Segundo Fernando Cardim, o austríaco Joseph Schumpeter seria adepto da teoria da propagação para a explicação dos ciclos. Para ele:

Estas teorias propõe que a adapatação de uma economia capitalista a uma mudança exógena tem a forma de uma ou de muitas ondas. Contrariamente aos modelos precedentes [ os de moto contínuo, segundo o autor, exemplificados pela tese Kondratieff], cada ciclo é visto como um indíviduo histórico, começando quando um estado de repouso ou de 'normalidade' é rompido por um choque exógeno. A absorção do choque é marcada por avanços e defasagens que definem a margem ondular do propcesso. (...) podem apenas explicar a regularidade de estágios de um dado ciclo, mas não a periodicidade de um processo cíclico. ${ }^{207}$

E dentre esses modelos, qual seria o mais adequado para se interpretar a História econômica da República Velha? Volte-se a metáfora das Olimpíadas. São círculos concêntricos, interligados e interdependentes. Limitar a interpretação a apenas um deles é empobrecer a possibilidade de se entender o passado. Este é dinâmico, repleto de contradições e olhares distintos, nem sempre isentos, muito menos racionais.

\subsection{A Moeda e Seus Percalços}

A moeda nasceu com a expansão econômica. Nas economias de escambo, a falta de padrão, a dificuldade das trocas e a desconfiança eram aceitas, enquanto havia poucas trocas de mercadorias. À medida que avançam as trocas e as relações comerciais, o escambo tornava-se inviável. Buscou-se um produto que substituísse não só as mercadorias em si, mas que tivesse um valor intrínseco, fosse de fácil circulação e aceitação e, principalmente, estivesse dotado da fidúcia em seu valor. Esta primeira

\footnotetext{
${ }^{207}$ CARVALHO, Fernando Cardim de. Keynes, a instabilidade do capitalismo e a teoria dos ciclos econômicos. Instituto de Pesquisa e Planejamento Econômico. Rio de janeiro. 1988. 18(3). Pág. 747
} 
forma foi a moeda metálica. Tal moeda era uma mercadoria e possuía valor de troca e valor de uso. Perdurou sua força e sua resistência por dezenas de séculos.

Somente com o Renascimento Comercial e Urbano dos séculos XII a XV que aos poucos a moeda foi perdendo sua predominância no mundo das trocas. Instituíramse letras de câmbio, construíram-se bancos, emitiram-se títulos. O mercado capitalista cada vez mais volumoso e expandindo-se pelo mundo precisava de moedas mais ágeis, menos dependentes do metal em si ( predominavam o ouro, a prata possuía um quarto das cunhagens e o cobre não passava de $5 \%$ do total), menos afeitas a falsificação.

A moeda perdia sua principal característica social: a aceitação geral, o fator psicológico de que tenho algo em mãos que além de seu valor intrínseco, é dotado dum valor de troca. As rotas em expansão e a mundialização da economia adicionavam outros problemas: o peso excessivo de moedas de metal e a possibilidade de roubos. Preocupados com as fraudes e roubos, os comerciantes começavam a depositar seu ouro e prata em Casas de Custódia. Ourives, abadias, bancos, investidores em sua maioria judeus, guardavam o ouro e emitiam um certificado de depósito. Este, por sua vez, possuía capacidade de circulação, tornou-se uma moeda confiável e com $100 \%$ de garantia no resgate. Era a moeda-papel.

Nos três séculos seguintes ( XVI ao XIX), o capitalismo expandiu para todos os cantos da terra, a economia se industrializou, as trocas comerciais multiplicaram-se aos milhões. O lastro de garantia do papel excedeu seus depósitos. A quantidade de dinheiro em circulação era três, quatro e às vezes até sete vezes a quantidade de ouro depositado. A moeda-papel transmutara-se em moeda fiduciária e depois moeda bancária ( com a profusão de cheques). Em fins do século XIX, entrava-se no período do papel-moeda, sendo que este perdera seu valor de uso e agora possuía apenas a função de troca.

Segundo Lopes \& Rossetti ${ }^{208}$, a moeda tem atualmente seis funções:

1) Intermediária de Trocas

A moeda permite a superação da economia de escambo. Facilita a especialização da produção e a divisão do trabalho. Reduz o tempo dos negócios e permite a sociedade decidir quando, quanto e em que condições irá adquirir a mercadoria;

2) Medida de Valor.

Racionaliza as informações criando um sistema lógico de preços e salários. Permite a contabilidade social e o cálculo do valor agregado da mercadoria;

\footnotetext{
${ }^{208}$ LOPES, João do Carmo \& ROSSETTI, José Paschoal. Economia monetária. $9^{\text {a }}$ Ed. Revista, ampliada e atualizada. Editora Atlas. São Paulo. 2009. Págs. 18 a 24
} 
3) Reserva de Valor

A moeda é um reservatório de valor, desde o momento em que é recebida até o momento em que será gasta. Por ter maior liquidez e contar com menor grau de incerteza nas transações, é o meio primordial de valor reservado;

4) Função Liberatória

A moeda permite ao seu possuidor livrar-se de dívidas, liquidar débitos presentes e pretéritos e sair da posição passiva de quem não as tem;

5) Padrão de Pagamentos Diferidos

A moeda pode antecipar seus pagamentos ou comprometer-se a liquidar ativos financeiros. Ao pagar os salários, o empregador antecipa a renda advinda da venda da mercadoria que ainda não ocorreu. Investindo no capital fixo da empresa, o empresário dá garantias futuras ao mercado financeiro da quitação dos empréstimos;

6) Instrumento de Poder

Por ser um título de crédito, a moeda dá ao seu possuidor poder político e social. Afinal, é a detenção de mais ou menos moeda que permite a sociedade criar, perpetuar e ampliar as desigualdades sociais e o acesso aos bens.

Segundo os mesmos autores, são características essenciais da moeda: a sua indestrutibilidade ( afinal, mesmo que uma moeda seja danificada, outra será emitida com os mesmos atributos); a inalterabilidade do seu valor; sua homogeneidade no mercado; a capacidade de transferibilidade e, por último, sua facilidade de manuseio e transporte.

\subsubsection{A moeda no Brasil}

Entre 1688 e 1808 o sistema circulante brasileiro era bimetalista. Cunhadas em Portugal, as moedas tinham como medida principal a oitava de ouro ( equivalente a 3,585g de ouro, uma oitava de onça). As moedas, cunhadas em Europa, sempre contavam com valor dobrado e sem frações: 10 réis, 20, 40, 80, 160, 320, 640 e 960 réis. Em 1722, a Coroa Portuguesa fez uma reforma monetária no sistema, devido a abundância mineral. Uma oitava de ouro passou a valer 1200 réis. A moeda de prata valia 120 réis, ou seja, um décimo do ouro. A dificuldade eram os valores fracionados. A arroba de carne, por exemplo, valia de 75 a 85 réis no século XVIII. Como ficava o troco? 
Na região aurífera de Minas o ouro do fundo das bateias era vendido por 2 vinténs, o que totalizava 75 réis. A Coroa pagava com moedas de 80 réis e como não havia troco, os comerciantes/ faisqueiros embolsavam a diferença de 5 réis - como os atuais comerciantes que nos dão troco em bala. A Coroa não teve dúvida, mandou cunhar uma moeda de cobre de valor exato: 37,5 réis. Acabara-se o problema de troco, afinal 2 vinténs-ouro ( como era denominada a moeda) equivaliam a 75 réis. Vem daí o ditado popular: "não vales nem um vintém", ou seja, nem uma mísera moeda fracionada de cobre.

A falta de padrão de pesagem fez a riqueza das casas de cunhagem por quase 3 séculos. Com a vinda da família real em 1808 a situação é crítica. Quase todo o meio circulante era constituído por moedas metálicas (2/3 delas de ouro). Os constantes endividamentos e as moedas deixadas para trás na fuga da perseguição napoleônica, trouxeram uma carência nos meios de pagamento. A abertura dos portos, as obras públicas realizadas na colônia a partir de então, bem como as medidas liberalizantes para investimentos econômicos no Brasil fez nascer o 'bilhete de permuta', recibos emitidos em garantia para moedas metálicas, com endosso e capacidade de circulação, um primórdio do papel moeda. 1808 marca também a abertura do $1^{\circ}$ Banco do Brasil.

As rebeliões populares como a de Pernambuco 1817, a guerra da Cisplatina e os gastos da corte encontraram um financiador direto: o Banco do Brasil. O acordo da Independência com pagamento de indenizações a Portugal piorou o quadro. Em 1827, as moedas de cobre cunhadas desde a regência de D. Pedro eram em sua maioria falsas. O imperador baixa um decreto: todas as moedas de cobre deveriam ser trocadas por títulos do Tesouro. Nascia o papel moeda. Dois anos depois o Banco do Brasil é liquidado. A emissão passa a ser centralizada pelo tesouro nacional.

Um pouco antes da vinda de D. João VI, José da Silva Lisboa ( o futuro Visconde de Cairu) será o responsável pela introdução no Brasil da economia política. Ele introduziu uma ciência liberal influenciada por Adam Smith com alterações importantes que a adaptavam à realidade brasileira. Cairu era nacionalista, comercialista e industrialista. Lembrando que para ele, indústria era a produção engenhosa, aquela em que a mercadoria produzida não dependia apenas do trabalho braçal. Defendendo a instalação da indústria no país, com a família real por aqui, Cairu no "Observações sobre a franqueza da indústria, e estabelecimento de fábricas no Brasil” (1810), diz:

A propriedade do pobre, fundamento de todas as outras propriedades, está no seu engenho, e mãos: ele tem o incontestável direito de 
trabalhar, bem como o risco de empregar fundos, no que cada qual melhor sabe e pode, sem ofensa dos mais indivíduos, e do estado. Este é um direito claro e sagrado, e promove nas competentes épocas e circunstâncias a opulência nacional. Por isso o sistema colonial arrasou muito a possível população e grandeza do Brasil, obrigando a uma forçada divisão de trabalho os braços e capitais do país, não permitindo outros empregos senão os da agricultura, e mineração, artes ordinárias, etc. Assim se deixaram de estabelecer algumas manufaturas úteis, que teriam cabimento na ordem natural das cousas, e a indústria e riqueza do povo só correu por certos grandes canais, e com desnecessárias restrições, podendo correr por muitos outros e mais variados veículos, sem conflitos nem abarcamentos. ${ }^{209}$

Cairu adianta Friederich List, que em "Sistema Nacional de Economia Política" criticou a teoria das vantagens comparativas, segundo a qual cada país deveria se ater as suas especialidades. Cairu, como List décadas depois, entendiam que o protecionismo era importante num comércio mundial assimétrico. O livre mercado deveria ser relativizado:

$\mathrm{O}$ que verdadeiramente causa justo temor, e efetivamente afasta as mais úteis empresas de indústria, não é o receio de rivais nos estabelecimentos novos; mas o ter-se de lutar continuamente com a hidra dos exclusivos, que têm mil cabeças, e pulam e recrescem incessantemente, como as tênias e polipos, quando não se cortam pelas entranhas vitais. Tudo será perdido, se as víboras e escorpiões dos monopólios, ao princípio de um estado nascente, se acoitarem em suterrâneos esconderijos. Ainda em florido prado se andará com sustos, e a cada passo se dirá latet anguis in herba.

Onde a lei da franqueza e livre concorrência é inviolavelmente guardada, os especuladores e projetistas, verdadeiramente hábeis e industriosos, não andam esbaforidos, e desperdiçando o seu tempo em inquirir se o país tem privilegiados com exclusivos, mas se aí realmente há demanda de fábricas, e se podem bem pagar os seus produtos, e sustentar-se o estabelecimento. A concorrência só pode ter

\footnotetext{
${ }^{209}$ LISBOA, José da silva. ( Visconde de Cairu). Observações sobre a franqueza da indústria, e estabelecimento de fábricas no Brasil. Senado federal. Coleção Biblioteca Básica Brasileira. Brasília. 1999. Pág. 51
} 
o efeito favorável ao público, de diminuir os ganhos lesivos, ou desnecessários. $^{210}$

Jose Luis de Almeida Nogueira foi professor do largo do São Francisco, tendo assumido a cadeira de Economia Política entre os anos de 1896 a 1914. Foi dos mais influentes professores da elite governante da república velha. Defendia a propriedade privada e o direito de herança. Criticava a tradicional improdutividade das lavouras brasileiras. Aceitava a intervenção social do Estado. Segundo ele, o mercado tem crises de sub-consumo e superprodução, cabendo ao Estado a interferência nos momentos de crise. Porém a maior influência de Nogueira e, portanto, de boa parte de nossos políticos e economistas foi Henry Dunning MacLeod. Para Nogueira, seus ideais:

(...) eram do mais puro liberalismo. Somos sectários da escola inovadora de MacLeod. Não levamos, todavia, como o preclaro economista escocês, a extremas conseqüências o princípio individualista, quando em conflito com os interesses fundamentais da comunhão social. Tais interesses temo-los também como direitos de coletividade, oriundos da solidariedade humanas. Deve, pois, a sociologia consagrar princípios tendentes a operar a harmonia dos direitos da sociedade com a liberdade humana, e não menos os direitos de humanidade com a liberdade social. ${ }^{211}$

A própria definição de Economia Política é a mesma de MacLeod:

...a ciência que tem por objeto as leis que governam as relações das quantidade permutáveis. Adota-se a visão da economia como a ciência das trocas e não mais como a ciência da riqueza. A centralidade da circulação que já era uma característica da Economia Política no Brasil é reforçada... ${ }^{212}$

Em relação aos bancos emissores, Nogueira defendia que a intervenção governamental era necessária quando objetivasse defender o interesse público. Em relação a moeda, define-a como tendo um valor em si e conter caráter liberatório. Para o

\footnotetext{
${ }^{210}$ LISBOA, José da silva. ( Visconde de Cairu). Observações sobre a franqueza da indústria, e estabelecimento de fábricas no Brasil. Senado federal. Coleção Biblioteca Básica Brasileira. Brasília. 1999. Pág. 85

${ }^{211}$ GREMAUD, Amaury Patrick. Das controvérsias teóricas à política econômica: pensamento econômico e economia brasileira no segundo império e na primeira republica (1840-1930). Doutorado apresentado na Faculdade de Economia e Administração da USP. 1996. Página 50

${ }^{212}$ Ibid. Págs. 50 e 51
} 
economista paulista a moeda não é um instrumento de troca, mas o seu fim. Sua função é eliminar a troca e não facilitá-la. Liberta o comércio de suas dificuldades ao separar a compra da venda.

Aí reside a importância do pensamento de MacLeod, introduzido por Nogueira: as questões monetárias e as formas de se expandir o crédito. $\mathrm{O}$ antigo debate Metalista poderia ser superado pelas propostas Papelistas, estes caracterizados:

...uma corrente mais favorável à ampliação do crédito para a
promoção do desenvolvimento econômico, de uma defesa na
constituição de bancos emissores de notas para o desenvolvimento de
um sistema bancário com maior utilização do chamado multiplicador
bancário, ou da dinamização do crédito bancário... ${ }^{213}$

\subsubsection{Metalistas e Papelistas}

Os debates políticos, parlamentares e econômicos relativos ao meio circulante e ao sistema financeiro brasileiro como um todo perpassaram o Império a partir da década de 1840 e avançaram pela República Velha. O cerne do debate ocorreu entre duas linhas de pensamento: os denominados Metalistas e doutro lado, os Papelistas. Os primeiros eram representados por aqueles setores que defendiam a moeda com padrão metálico. Cabendo aos segundos a defesa de um padrão monetário metálico menos rígido e mais próximo do padrão fiduciário.

A origem das disputas entre Metalistas e Papelistas vem dos calorosos debates ocorridos após as Guerras Napoleônicas. Bulionistas ${ }^{214}$ eram os economistas que defendiam um padrão rígido da moeda metálica. Em geral, os economistas clássicos são bulionistas. Opostos a eles, apareceram os anti-bulionistas, adeptos de uma separação entre o valor da riqueza e a quantidade de metais. Pedro César Fonseca nos explica que: ...Sobre isto, parece inegável que os anti-bullionists, assim como Keynes (e os papelistas brasileiros), de uma forma geral rejeitavam a convicção ricardiana pela qual a moeda possui valor intrínseco, expresso por quantidades de trabalho incorporadas expressas em ouro, e que não afetava as variáveis reais - entendendo-se, portanto, como neutra a longo prazo. Em

\footnotetext{
${ }^{213}$ GREMAUD, Amaury Patrick. Das controvérsias teóricas à política econômica: pensamento econômico e economia brasileira no segundo império e na primeira republica (1840-1930). Página 55

${ }^{214}$ Bullion, atualmente significa lingote de ouro. No século XVI, entretanto, a palavra representava as medidas tomadas pelo ministro da Fazenda de Luís XIII, o advogado Charles Bullion. Sua crença central era de a riqueza estava na quantidade de ouro e prata acumulada
} 
contraposição, procuravam lembrar que o mercado monetário era mais complexo, onde influíam expectativas, clima de confiança e convenções, com impacto decisivo em variáveis como a velocidade de circulação monetária e, portanto, indissociáveis da execução da política monetária ${ }^{215}$

O mesmo autor logo depois compara papelistas e metalistas:

Os metalistas defendiam ferrenhamente $\mathrm{o}$ padrão ouro e a conversibilidade da moeda; para tanto, encontravam respaldo na teoria econômica convencional e na política do país hegemônico, a GrãBretanha. Já os papelistas, frente à ausência de um corpo teórico de mesma envergadura para defender o desapego ao que consideravam amarras às políticas monetárias e cambiais, recorriam à razão prática: a experiência, e não uma teoria, demonstrava qual o melhor caminho a seguir. ${ }^{216}$

Por ser uma linha de pensamento menos teórica ( pelo menos até o início do século XX), os Papelistas tiveram como expoentes, alguns poucos economistas e empresários, os quais com a sua prática de negócios pregavam no Brasil uma maior flexibilidade no mercado monetário. Entre as personalidades tivemos o Barão de Mauá e, posteriormente, nosso Percival Farquhar. O dinamismo econômico, os investimentos da livre iniciativa e o risco inerente da atividade empresarial não poderiam se limitar ao padrão rígido das moedas metálicas e do profundo intervencionismo no meio circulante perpetrado pelos Metalistas.

Para Pedro Cesar Fonseca, os Metalistas acreditavam que:

..a prioridade da política econômica era a estabilidade e a política cambial - e, portanto, a definição da taxa de câmbio tornava-se variável prioritária. Defensores do padrão ouro, estabeleciam a relação entre política monetária e balanço de pagamentos: metais preciosos ingressariam naturalmente no país se a economia fosse saudável e qualquer oferta de moeda sem lastro causaria inflação. A política monetária deveria ser subordinada à política cambial. Via de regra os

\footnotetext{
${ }^{215}$ FONSECA, Pedro Cezar Dutra. A controvérsia entre metalismo e papelismo e a gênese do desenvolvimentismo no brasil. Encontro da associação nacional de professores de economia. 2008.pág. 5. Disponível em: <http://www.anpec.org.br/encontro2008/artigos/200807210827300-.pdf $>$. Acessado em 24 de outubro de 2016

${ }^{216}$ Ibid. pág. 6
} 
metalistas apoiavam-se nos grandes mestres da Economia Clássica, como Smith, Ricardo e Say. A taxa de juros era entendida como fenômeno real, à la Ricardo, dependente da taxa de lucro. Maior oferta de moeda não alterava o nível de atividade. ${ }^{217}$

Por sua vez, para os Papelistas:

...dos mais moderados aos mais radicais, [ a preocupação] era com o nível de atividade econômica. Sua pergunta mais freqüente, qual o nível de oferta monetária mais condizente com o ânimo dos negócios, consistia verdadeira heresia para os metalistas. Mauá, um de seus primeiros defensores, defendia o que se convencionou denominar "requisito da elasticidade": a oferta de moeda deveria ser flexível ou elástica a ponto de não interferir negativamente nas atividades produtivas. Menos teóricos e mais pragmáticos, apresentavam-se como coerentes com o bom senso: simplesmente o governo deveria ajudar, e não prejudicar a economia. ${ }^{218}$

Para os metalistas falta ao meio circulante um lastro metálico. O papel-moeda em circulação tem um valor em si, não tem valor intrínseco, vale pela quantidade de notas ou moedas fiduciárias e bancárias que estão em circulação. Portanto, para os metalistas, quanto mais papel-moeda, menor seu valor de troca e uso, o que ocasiona mais inflação e câmbio desvalorizado. Ou seja, na prática, as políticas emissionistas dos papelistas eram prejudiciais ao negócio central tanto do Império, quanto da República Velha: a exportação quase monocultora do café.

Por sua vez, a moeda metálica tem um valor intrínseco: a quantidade de metal nela inserida. A moeda metálica, literalmente, valia quanto pesava. Se o valor da moeda diminuísse, bastaria derreter parte do meio circulante e, dessa forma, diminuindo a quantidade de metal em circulação, valorizando a moeda. Com uma moeda metálica forte, o câmbio seria valorizado. Caso o mercado sentisse carência na obtenção de metais para a confecção de novas moedas, buscariam-se as mesmas no mercado externo.

Câmbio valorizado e moeda forte eram do interesse da oligarquia do café-comleite. Os danos ao mercado interno eram evidentes. As importações eram brecadas pela

\footnotetext{
${ }^{217}$ FONSECA, Pedro Cezar Dutra. A controvérsia entre metalismo e papelismo e a gênese do desenvolvimentismo no brasil. Encontro da associação nacional de professores de economia. 2008.pág. 5. Disponível em: 〈http://www.anpec.org.br/encontro2008/artigos/200807210827300-.pdf> . Acessado em 24 de outubro de 2016. Pág. 8 ${ }^{218}$ Ibid. Pág. 9
} 
valorização dos réis e seus contos. Abriam-se oportunidades para a indústria nacional substituir as importações por similares nacionais, porém com a carência de moedas, a centralização dos bancos emissores e os desincentivos à livre iniciativa; as tentativas de formação de uma burguesia industrial brasileira andavam a passos de tartaruga.

Em que pesem os estudos relativos aos discursos parlamentares demonstrando que, possivelmente, muitos membros das oligarquias econômicas lucravam tanto em ciclos Papelistas quanto nos Metalistas, a regra é que tanto em tempos idos como na contemporaneidade, a distância entre o discurso dos ilustres parlamentares e as práticas políticas e econômicas adotados é quilométrica.

A estabilidade da moeda e do câmbio era o cerne para os Metalistas. O problema para eles seria a falta de ouro e prata em espécie. Para suprir a possível carência de metal, eles pregavam o aumento da produção de ouro, com buscas de novas jazidas ou novas áreas de minérios (quase nunca com melhorias nas técnicas extrativas ou com o fim da super-exploração da massa trabalhadora, seja no garimpo ou na mineração). Crescendo a produção de ouro e prata, seria retirado o papel moeda e atraíriam-se capitais externos. Pois, os investidores estrangeiros que deixaram o país nos ciclos de abundância Papelista, voltariam naturalmente com a redução do meio circulante. Até porque, segundo os Metalistas, diminuindo a oferta, o preço do metal valeria mais, atraindo capitais. Haveria uma tendência ao equilíbrio:

...do valor da moeda, automaticamente. Do mesmo modo, o papelmoeda que é apenas signo do metal - a moeda-papel segundo alguns se houver plena conversibilidade a um padrão estabelecido, quando cai o valor da moeda em função de algum excesso de oferta, existe a tendência de se corrigir este excesso, já que a elevação de preços faz com que diminua a oferta de metal e portanto reduza a emissão de papel já que este é trocado a par pelo metal. ${ }^{219}$

Como visto anteriormente, é princípio incontestável que o valor da moeda vem do uso a que ela se presta, muito mais do que a matéria de que é formada. O papelmoeda é um intermediário de trocas muito mais eficiente, pois de fácil circulação e não carente de escassez. Indestrutível, com capacidade de circulação rápida e infinita. Crescendo os negócios numa sociedade, devem crescer os papéis-moedas em

\footnotetext{
${ }^{219}$ GREMAUD, Amaury Patrick. Das controvérsias teóricas à política econômica: pensamento econômico e economia brasileira no segundo império e na primeira republica (1840-1930). Doutorado apresentado na Faculdade de Economia e Administração da USP. 1996. Página 86
} 
circulação. Isto não possui nenhuma artificialidade. E a partir da segunda metade do século XIX, a economia e a sociedade brasileira passaram por profundas transformações: no sistema de transportes, com as ferrovias que reduzem a relação tempo-espaço tanto do comércio, quanto da circulação das pessoas; nas atividades produtoras, com o desenvolvimento crescente do setor industrial; no mercado interno, afinal com a urbanização do país, as necessidades de consumo se alteravam e ampliavam suas vontades; no mercado de trabalho, seja com a Abolição, ou com as novas levas de imigrantes. O Brasil fervilhava tanto quanto os cavalos encilhados.

Assim, para os Papelistas, não se deve esperar mais ouro metálico para emitir novas moedas. O que vale mesmo e determina a expansão do meio circulante é o volume de transações. Quanto mais se apoiam as atividades industriais, mais se enriqueceria o país. A moeda nunca seria excessiva, pois viria acompanhada do aumento da produção, do mercado e do consumo. Tal condição econômica, por sua vez, só seria possível com vários bancos emissores, pois somente eles conhecem a demanda do mercado e, nesse sentido, teriam um controle maior sobre a especulação monetária. Além disso, a profusão de bancos emissores levaria a concorrência e esta, autorregularia o mercado. Gremaud cita outro ponto conflitante entre os dois grupos:

Os papelistas alegam que os metalistas confundem capital com moeda. Para estes últimos os papeis emitidos pelos bancos são apenas signos monetários, mas não capital. A definição da taxa de juros é um fenômeno basicamente real, decorrente do encontro entre poupadores e investidores intermediados pelos bancos. Já os papelistas afirmam as considerações de ordem monetária na determinação das taxas de juros, que podem ser afetadas pela emissão de notas bancárias. Estas são instrumentos de crédito, mas fazem as vezes também de meios de pagamento. $^{220}$

Não podemos esquecer a lição de Heitor Ferreira Lima de que nossos liberais econômicos eram paradoxalmente conservadores políticos. Praticávamos um laissez faire com defesa ferrenha da escravidão. ${ }^{221}$

\footnotetext{
${ }^{220}$ GREMAUD, Amaury Patrick. Idem. Pág. 88

${ }^{221}$ LIMA, Heitor Ferreira. História do pensamento econômico no Brasil. Companhia Editora Nacional. Rio de Janeiro. 1976. Coleção Brasiliana no 360. Págs. 93
} 
Após um período de emissão entre as décadas de 1830 e 1840, num sistema misto, em 1846 volta o padrão-ouro. As correntes econômicas Metalistas predominam no Brasil. Esta reforma:

...preparou as condições favoráveis à retomada do desenvolvimento econômico, que ganhou considerável impulso na segunda metade do século e inaugurou novo período na história econômica do País. A partir de 1850, a tranquilidade interna foi restabelecida, atenuadas as oposições regionais e reforçada a unidade do País. Enquanto a insegurança dos sistemas monetário e financeiro fazia da imensidão territorial do país um risco à unificação do mercado nacional, o saneamento do sistema monetário mostrou ela era fonte de abundância e de diversidade de recursos, constituindo elemento decisivo do progresso econômico. O meio, então, estava mais apto a se beneficiar do progresso técnico que a revolução industrial vinha proporcionar no mundo ocidental. O comércio exterior desenvolveu-se e a balança comercial tornou-se favorável a partir de 1854 até o final do Império, com exceção de apenas 4 anos. O Banco Comercial do Rio de Janeiro e o Banco Mauá fundiram-se, dando origem, em 1851, ao $2^{\circ}$ Banco do Brasil. Este adquiriu os direitos de emissão de outros bancos privados, reestabelecendo o monopólio das emissões de outros bancos privados. Este novo banco foi encarregado de substituir as notas do tesouro pelas suas. Seu limite de emissão foi fixado no dobro do capital disponível. Subordinado ao princípio da unidade de emissão, adotouse a fixação do teto máximo...222

Com a crise bancária de 1857 iniciam-se calorosos debates na Câmara. No gabinete do Visconde de Abaeté a responsabilidade pela recessão de 1857 passa a ser impingida ao excesso de bancos existentes no Brasil. Contra esta posição estavam o Barão de Mauá, Martinho de Campos, Paranaguá, Saraiva e a favor da tese Marcelo Coelho, Sampaio Viana e Sales Torres. Os anos de 1857 a 1860 foram prósperos economicamente. Mais de 80 empresas de pesca, ferrovias, mineração e navegação foram abertas no país. O ministro da Fazenda Sales Torres adotou a pluralidade bancária, favorecendo empresários como Mauá. A crise de 1864-65 foi ainda pior para o

\footnotetext{
${ }^{222}$ LOPES, João do Carmo \& ROSSETTI, José Paschoal. Economia monetária. $9^{\mathrm{a}}$ Ed. Revista, ampliada e atualizada. Editora Atlas. São Paulo. 2009. Pág. 39
} 
Império. Era a quebra do Souto, da qual "até os papagaios falaram”. As medidas metalistas voltaram e segundo Ferreira Lima “...em nome do combate à inflação, da estabilidade cambial, da metalização da moeda, acompanhada de tarifa baixas foi se sufocando nosso primeiro surto industrial.,223

Condição esta reafirmada pela ideia de que: “....assim, o que se conseguiu com a política monetária ortodoxa, então praticada, foi o entravamento da iniciativa industrial nascente..." 224

A relativa estabilidade econômica permanece até a Guerra do Paraguai ( 18641870), devido aos gastos excessivos, o teto de emissão ou alavancagem passou a ser de 5 vezes o ouro depositado. Novas medidas Metalistas são tomadas. A partir de 1870 voltam as políticas heterodoxas e as tarifas protecionistas. Estas eram necessárias pelas quedas dos preços do açúcar, algodão e café. Mauá tem nova e última oportunidade. Duas décadas depois, a valorização da moeda imposta por Murtinho abrem espaço para a entrada de Farquhar.

A pluralidade de emissões com regime de teto máximo voltou apenas no ano da Abolição, em virtude da abundância de ouro no mercado ( descobertas das jazidas australians e do oeste americano). Em meio a esse período, o Brasil tomou pelo menos 3 grandes empréstimos internacionais ( visto no Capítulo 2).

Nos estertores do Império renascem as disputas entre Metalistas e Papelistas. O Visconde de Ouro Preto apresenta sua reforma para salvar os dois pilares do século XIX: o Império e a Aristocracia escravista:

...era a reorganização do sistema monetário, prevendo o resgate do papel-moeda, a conversibilidade em ouro das notas em circulação e a criação de um banco central para controlar a emissão monetária e fiscalizar os bancos comerciais. Mas o sistema efetivamente implantado caminhou no sentido contrário, sob inspiração dos defensores do papel-moeda e dos bancos emissores múltiplos.... ${ }^{225}$

Proclamada a República, a crise do encilhamento se organizava. Os ciclos se alternavam, alguns de longa duração, outras de média e curta extensão. A economia, como produção de bens num mundo de recursos escassos, não era uma ciência exata

\footnotetext{
${ }^{223}$ LIMA, Heitor Ferreira. História do pensamento econômico no Brasil. Companhia Editora Nacional. Rio de Janeiro. 1976. Coleção Brasiliana no 360. Págs. 95 a 99

${ }^{224}$ Ibid. Pág. 100

${ }^{225}$ LOPES, João do Carmo \& ROSSETTI, José Paschoal. Economia monetária. 9ª Ed. Revista, ampliada e atualizada. Editora Atlas. São Paulo. 2009. Págs. 39 e 40
} 


\section{$\underline{7.2 .3 \text { Agraristas e Industrialistas }}$}

A partir da segunda metade do século XIX o Café passa a ser responsável por mais da metade do PIB do país. Em fins daquele século sua contribuição na Renda Nacional ultrapassava os dois terços. A economia brasileira, agrária, latifundiária e ainda escravista era constituída de "ilhas produtoras",226 de pouca importância em meio ao quase monopólio financeiro e político do café paulista e das elites mineira e carioca (o Rio era a terra da corte Imperial e depois a sede da República até 1960).

As tentativas de industrialização do Brasil datam da década de 1840, principalmente com Irineu Evangelista de Souza ( Barão e depois Visconde de Mauá). Começam a se formar naquele período também as primeiras instituições bancárias e casas de crédito. A Praça do Comércio no Rio é constituída em 1867. A profissão de corretor da Praça ( hoje Bolsa de Valores) foi regulamentada mais de duas décadas antes. Não contava, porém, com a simpatia de boa parte da elite agrária, muito menos com a de D.Pedro II.

O Brasil se organizava administrativamente, com códigos e regulamentos: o Código Comercial, parte dos quase 1000 artigos em vigor até hoje, é de 1850. A Lei de Terras, do mesmo ano da carta comercial, veio regulamentar a propriedade, impedindo o acesso à terra aos livres e não abastados, aumentou a concentração e regulamentou a exclusão da grande maioria da população a posse e usufruto da propriedade rural.

A República, em seu ideal positivista, aprova em 1890 o Código Penal, um projeto do abolicionista Joaquim Nabuco, que após algumas poucas emendas foi ratificado pelo ministro da Justiça Campos Salles, futuro presidente. O objetivo era alterar completamente o código imperial, em vigor havia 60 anos. Este documento previa sanções brutais como a galé (trabalho forçados que poderiam ser perpétuos), penas de degredo, a prisão perpétua e a pena de morte. Aquele código republicano procurou um tratamento mais científico, tanto ao crime quanto ao criminoso. Nabuco introduziu a Criminologia no ordenamento jurídico penal:

A introdução da Criminologia no país representa, deste modo, a possibilidade simultânea de compreender as transformações pelas quais passava a sociedade, implementar estratégias específicas de

\footnotetext{
${ }^{226}$ Milton Santos em “A natureza do espaço” define a ocupação territorial do Brasil entre o Período Colonial e o final do século XIX como um processo de 'ilhas' de povoamento em meio a um 'mar' de terras não ocupadas. Segundo o geógrafo, o território se formou a partir de núcleos populacionais como Salvador, Rio, Recife e Olinda, Ilhéus, São Vicente e Santos, São Paulo e outras mais, cidades, com caráter aglutinador e isoladas umas das outras e por outro lado espalhadas em meio ao imenso vazio que era o sertão brasileiro.
} 
controle social e estabelecer formas diferenciadas de tratamento jurídico-penal para determinados segmentos da população. Enquanto um saber normalizador, capaz de identificar, qualificar e hierarquizar os fatores naturais, sociais e individuais envolvidos na gênese do crime e na evolução da criminalidade ${ }^{227}$

Entre os criminologistas que davam sustentação teórico-científica ao Código Penal de 1890 estava Cesare Lombroso. O professor italiano procurava demonstrar a relação entre características físicas e mentais dos criminosos. Assim, por exemplo, o tamanho da mandíbula poderia ser associado à psicopatologia criminal, ou o inatismo dos sociopatas. Desacreditado atualmente, mas bastante útil numa sociedade elitista, branca, na qual os elementos perigosos eram quase sempre os mais de dois terços de negros e mestiços.

Coube ao jurista da academia recifense Clóvis Beviláqua, a elaboração do Código Civil. O projeto foi entregue em 1899, no governo Campos Salles, mas contou com o descrédito dos acadêmicos e os ciúmes de Rui Barbosa, que em dois dias apresentou um relatório desconsiderando os quase dois mil artigos. Os embates políticos para a sua aprovação perduraram por 17 anos e apenas no governo Wenceslau Brás o Código Civil entrou em vigor ( aprofundamento deste tema apareceu no capítulo 5). A República Velha terminara sua obra legislativa e impunha a nova ordem jurídica ao país: vigoravam a Constituição de 1891, o Código Penal de 1890 e o Código Civil de 1916; além destes, o Código Comercial de 1850 passara por reformas, introduzindo sutilmente as garantias empresariais num país de industrialização nascente.

A grande maioria de nossas empresas, desde a metade do século XIX, adotou o modelo societário da sociedade anônima. Basta uma leitura rápida sobre dois artigos do Código Comercial de 1850 para se entender o motivo:

Art. 298. Os socios das companhias ou sociedades anonymas não são responsaveis a mais do valor das acções, ou do interesse por que se houverem compromettido.

Art. 299. Os administradores ou directores de huma companhia respondem pessoal e solidariamente a terceiros, que tratarem com a mesma companhia, até o

\footnotetext{
${ }^{227}$ ALVAREZ, Marcos César, SALLA, Fernando \& SOUZA, Luís Antônio F. A sociedade e a lei: o código penal de 1890 e as

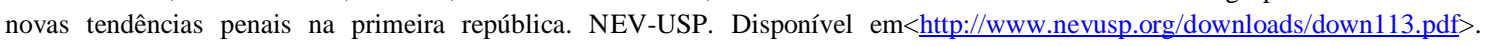
Acessado em 4/5/2015.
} 
momento em que tiver lugar a inscripção do instrumento ou titulo da sua instituição no Registro do Commercio (art. 296), effectuado o registro respondem só á companhia pela execução do mandato. ",228

Primeiro, os sócios não possuem capital diretamente investido nas empresas, mas apenas ações. Dessa forma, sua responsabilidade limita-se a quantidade de ações que terá em mãos, dificultando a cobrança dos credores em caso de quebra (como se denominava à época o processo falimentar de uma empresa). Segundo, porque ao se constituir como sociedade anônima, os bens particulares dos empresários nunca se confundiriam com os bens próprios das empresas. O sistema financeiro e a Bolsa do Rio poderiam movimentar seus papéis. A economia industrial brasileira dava seus primeiros passos.

Há quase um consenso entre historiadores sobre o papel determinante do café no início do desenvolvimento industrial brasileiro. Primeiro na Capital Federal, depois em São Paulo. Até a primeira guerra pelo menos, o Rio era o grande centro financeiro e econômico do país. Tornou-se um núcleo das atividades comerciais e dos sistemas de transportes. Em 1907 a capital do país era responsável por um terço da produção industrial nacional, São Paulo concentrava 16\%. Ao adentrarmos a década de 20 a situação rapidamente se inverte. Os paulistas passam a centralizar o maior número de indústrias, de trabalhadores do setor secundário e da produção total. Em 1938 o estado tem mais de $50 \%$ da produção total do país.

Pesaram nessa situação vários fatores: em primeiro lugar a oferta de trabalhadores livres e baratos, afinal mais de dois terços dos imigrantes procuraram São Paulo; outro aspecto foi a expansão da malha ferroviária, cortando a terra paulista e interligando as regiões produtoras de café no interior do estado ao porto de Santos que aos poucos tornava-se o maior porto de cargas do Brasil; o sistema ferroviário permitiu a formação de uma indústria mecânica, seja na reposição de peças ou na produção de pequenos reparos como vidros, couro, parafusos, o que colaborou para incentivar os investimentos de capital na indústria; outro fator, também ligado as ferrovias, foi a difusão das mercadorias nacionais e importadas por regiões distintas e distantes, os trens transportavam café, mas traziam chapéus, roupas, sapatos e outros produtos até então inacessíveis aos habitantes do sertão paulista; em quinto lugar temos as condições

\footnotetext{
${ }^{228}$ BRASIL. LEI N ${ }^{\circ} 556$, de 25 de junho de 1850. Codigo Commercial do Imperio do Brasil.
} 
naturais do solo e clima paulista, as férteis áreas de terra roxa encontrados no Planalto Arenito-basáltico ( Planalto Ocidental paulista), mais adequados ao plantio de café e um clima tropical alternadamente seco e úmido, importante ao crescimento dos cafezais. Por último, não menos importante, o capital advindo das exportações do café e o controle político do estado por décadas, fazendo com que as políticas econômicas sempre fortalecessem o produto paulista e, permanentemente, bancassem suas safras ruins ou o lucro reduzido em face das variações dos preços internacionais.

Aos poucos São Paulo adquiria as características de uma economia-mundo, definida por Braudel. Espaços geográficos, sociais, culturais e econômicos que transpõe os limites físicos e difundem um modo de vida, uma condição material de existência. Deduz o autor que:

(...) uma economia mundo é a soma dos espaços individualizados, econômicos e não econômicos, agrupados por ela: que a economiamundo representa uma enorme superfície ( em princípio é a mais vasta zona de coerência, em determinada época, em uma região específica do globo); que, habitualmente, ela transcende os limites dos outros grupos maciços da história. ${ }^{229}$

Outra análise da supremacia paulista encontramos em Heitor Ferreira Lima. Para ele, os fatores impulsionadores da atividade industrial no Brasil a partir da metade do século XIX:

I - A imigração, primeiro para as regiões temperadas do país, nos primórdios do século XIX e, a partir da década de 70 do mesmo século direcionada para os cafezais - especialmente os paulistas;

II - A superprodução de café nos inícios do século XX;

III - A Abolição e o crescimento vertiginoso do número de imigrantes, adicionados da substancial renda da cultura cafeeira, levaram à formação de um mercado de consumo, de considerável e crescente importância para os produtos industriais nacionais;

IV - O fornecimento de energia elétrica e a construção de grandes usinas geradoras em São Paulo e na Guanabara, reduzindo os custos das máquinas e permitindo o estabelecimento de indústrias médias de transformação, alicerçadas no fornecimento de energia barata naqueles dois estados;

\footnotetext{
${ }^{229}$ BRAUDEL, Fernand. O tempo do mundo. Pág. 14
} 
V - Melhorias e expansão do sistema ferroviário e rodoviário ( num segundo momento), que em conjunto com a energia abundante, os capitais excedentes do café e a mão-de-obra livre — seja de imigrantes ou de ex-escravos, estes em menor número -, transformaram o triângulo São Paulo, Rio e Minas numa área semelhante aos centros hulheiros dos Estados Unidos, Alemanha e Inglaterra;

VI - As sucessivas baixas cambiais impostas pelos governos da República Velha e a consequente redução do poder de compra dos produtos importados pelos brasileiros, levaram a uma pressão sobre a produção interna das mercadorias por parte de uma população que se urbanizava e aos poucos adquiria hábitos e necessidades de consumo característicos do Capitalismo Industrial. ${ }^{230}$

Essa expansão, segundo Lima, citando a obra de Roberto Simonsen “ A Evolução Industrial do Brasil”, tem um salto com a República:

Em 1889, ou seja, no ano da Proclamação da República, existiam em todo país 636 estabelecimentos industriais, cujo capital estava avaliado em 401.630:600\$000 ( valor de 1920), correspondendo isso a 25 milhões de libras, empregando forças de 65.000 cavalos e dando emprêgo a 54.169 operários. O valor global da produção era estimado em 507.092:587\$000. Dos capitais investidos na indústria, 60\% estavam no setor têxtil, $15 \%$ na alimentação, $10 \%$ nos produtos químicos, $4 \%$ na indústria de madeira, $3,5 \%$ no vestuário e objetos de toucador e $3 \%$ na metalurgia.

No primeiro ano da República, em 1890 foram fundados 38 bancos e 294 sociedades anônimas, somando um capital bastante elevado para a época, de 1.332 .800 contos de réis. No ano seguinte, 1891, arquivaram estatutos na Junta Comercial da Guanabara 51 bancos e 255 companhias diversas, envolvendo 1.397 .796 contos, perfazendo para os dois exercícios um total de 89 bancos e 549 companhias, num global de 2.720 .500 contos, que constituía importância respeitável, mesmo levando-se em conta a depreciação

${ }^{230}$ LIMA, Heitor Ferreira. Págs. 320 e 321. Texto com alterações e adaptações deste autor. 
monetária como consequência da inflação que principia então a tomar vulto. $^{231}$

Segundo Suzigan (1983), apesar de crescente, a participação da Indústria na formação do capital nacional bruto ainda era reduzida, comparativamente à da Agricultura na década de 1910. A renda desta última era cerca de oito vezes maior do que a produção industrial. Somente a partir dos anos 30, tanto o parque industrial brasileiro quanto a renda produzida por ele, começam a se aproximar e somente quatro décadas depois, suplantar o capital agroexportador.

Para Edgar Carone a pretensa contradição de interesses entre os agroexportadores e os industrialistas, nos primórdios do desenvolvimento desta última não eram reais:

Nos fins do Império não existe propriamente antagonismo entre a agricultura e a incipiente industrialização: a classe agrícola não vê um adversário nesta nova forma de produção; aliás, a pequena indústria é então um implemento da economia agrícola, pois lhe possibilita a mecanização do trabalho, os produtos alimentícios etc. É o comércio importador, de origem estrangeira, que clama contra os produtos caros, mostrando sua inferioridade diante do produto estrangeiro e pedindo, demagogicamente a defesa do consumidor. Como o início da República coincide com um movimento jacobino e nacionalista, estes grupos agem somente junto às autoridades, preconizando medidas favoráveis à importação etc. ${ }^{232}$

Nícia Vilela caminha no mesmo sentido ao analisar os discursos políticos do fim do Império e início da República:

A lavoura nunca fora propriamente contrária ao desenvolvimento industrial do país, preferindo, contudo, que ele se processasse lentamente para que não viesse agravar os problemas da falta de capitais e mão-de-obra que afetavam as atividades agrícolas. Era, além disso, particularmente contrária a uma política protecionista que prejudicasse o consumidor.

(...)

\footnotetext{
${ }^{231}$ LIMA, Heitor Ferreira. Pág. 321

${ }^{232}$ CARONE, Edgar. Instituições. Pág. 87
} 
De modo geral, foi essa a posição da lavoura durante o Segundo Império. À medida, porém, que, por um lado, a indústria se desenvolvia e suas reivindicações tornavam-se mais insistentes, e, por outro, cresciam as dificuldades da agricultura, começou-se a notar uma certa irritação das classes agrícolas, surgindo o argumento da incapacidade da indústria em abastecer o mercado nacional e, principalmente, o do sacrifício de muitos a favor de alguns privilegiados $^{233}$

Não há dúvidas, porém, que na República Velha, ao mesmo tempo em que há um predomínio da Oligarquia Cafeicultora e dos interesses dos agroexportadores, existe a ascensão da indústria, a urbanização do país e a constituição de um mercado interno essenciais à construção de uma economia de mercado. Joaquim Murtinho, o ministro do primeiro funding loan assim caracteriza a luta entre Agralistas ( Metalistas) e Industrialistas (Papelistas):

As grandes emissões que excitaram a febre de negócios, desenvolvendo os canais de circulação monetária, invadiram os campos destruindo a calma, a prudência e a sabedoria no espírito dos agricultores, infiltrando-lhes a ambição de grandes fortunas obtidas com grande rapidez. ${ }^{234}$

Para o homeopata do remédio amargo, o Brasil criara a indústria artificial, oposta a "verdadeira" indústria:

O que caracteriza uma indústria natural não é o fato de ter sua matéria-prima importada ou não, mas o de ter capacidade de produzir o máximo resultado possível em relação ao capital empregado com o mais baixo preço em um regime de livre concorrência. ${ }^{235}$

A pouco e pouco o país reduzia a importância da economia agrária, produtora de bens primários, excludente e periférica e desenvolvia seu potencial industrial, numa produção também concentradora de capital e renda e ainda periférica. As reformas financeiras de Joaquim Murtinho, defensor do setor agrário, permitiram,

\footnotetext{
${ }^{233}$ LUZ, Nícia Vilela. A luta pela industrialização. Págs. 61 e 62

${ }^{234}$ Citado por: GREMAUD, Amaury Patrick. Das controvérsias teóricas à política econômica: pensamento econômico e economia brasileira no segundo império e na primeira republica (1840-1930). Doutorado apresentado na Faculdade de Economia e Administração da USP. 1996. Página 105

${ }^{235}$ Ibid. pág. 106
} 
contraditoriamente à sua vontade, a expansão da produção industrial brasileira. Numa economia em ascensão, com o mercado financeiro internacional apoiando o governo e seu receituário Metalista, associados a um câmbio fixo e valorizado, Percival Farquhar poderia investir seus capitais, sua fome de especulação e seus dotes industrialistas. $\mathrm{O}$ mercado interno confiava no Brasil e nas suas elites. O imperialismo necessita destruir os antigos laços da produção provinciana para criar novos mercados e novas necessidades e introduzir o capitalismo industrial. As políticas econômicas Metalistas ao restringir a emissão de papel e manter o câmbio valorizado atraíam os empresários nacionais para a produção da "substituição de importações". Na luta contra a indústria “artificial", Joaquim Murtinho formatou as possibilidades da mesma: o capital industrial estrangeiro, representado por Farquhar e a crescente burguesia industrial nacional com sua produção para o abastecimento das necessidades de consumo de um país cada vez mais urbanizado.

\subsubsection{As idas e Vindas Econômicas da República Velha}

A República Velha marca uma separação quase definitiva entre a oligarquia rural e os setores industriais das cidades. Até o início da República esses setores se misturavam. Cafeicultores, comerciantes do café, comissários e importadores estendiam seus negócios para as indústrias nascentes, ferrovias, serviços públicos. O capital rural, industrial e financeiro se atrelava. Com o desenvolvimento do capitalismo industrial no país, o capital burguês se torna mais difuso e independente. E, aos poucos, dissocia-se de suas origens e torna-se uma classe própria, com interesses muitas vezes conflitantes aos da oligarquia do café-com-leite.

O sistema monetário e financeiro também irá acompanhar essas transformações. Era necessário que a moeda brasileira se aproximasse dos outros padrões monetários do mercado mundial e que se instituísse um Banco para centralizar as atividades financeiras e aos poucos, ditasse as regras do mercado monetário do país, desligando-o dos interesses quase que exclusivos do café.

O Brasil da República Velha era agroexportador e controlado por uma elite que acreditava que seus interesses e negócios eram os mesmos do país. A nação que emerge nos anos 1930 é distinta: cada vez mais industrializada, urbanizada ( segundo o IBGE, em 1946 o país passa a ter 51\% das pessoas morando em cidades) e com novos atores sociais que resistirão com mais vigor ao cabresto dos coronéis. 
Entre 1889 e 1930 os interesses corporativos do café foram os norteadores da política econômica. Mesmo sendo observadas algumas oscilações como as do câmbio: de 1889 a 1906 a lógica era o câmbio flexível; de 1906 a 1914, ano este do $2^{\circ}$ funding loan, vigia o câmbio fixo; entre 1914 e 1926 o câmbio volta a ser flexível e nos últimos anos da República Velha ele volta a rigidez.

Como visto no início deste capítulo, os ciclos econômicos ( como os olímpicos) não são rígidos, muito menos matematicamente calculados.

A política denominada de Encilhamento teve suas origens na expansão do meio circulante antes ainda da República. O período do ministério Ruy Barbosa ( 1890-91) acirrou os problemas. Não foi sucedido diretamente pelas políticas ortodoxas. Estas só vieram com Joaquim Murtinho no quadriênio 1898-1902. Leopoldo Bulhões deu continuidade ao Metalismo. As políticas heterodoxas voltaram com Hermes da Fonseca. Entre 1914 e 1917, em respeito aos acordos do $2^{\circ}$ funding loan, tivemos novo ciclo ortodoxo. A parte final do governo de Epitácio Pessoa e o início da administração Artur Bernardes adotaram as restrições emissionistas. A ortodoxia só voltaria por ocasião do acordo do $3^{\circ}$ funding loan em 1931.

Ou seja, assistiu-se a uma alternância entre ciclos Papelistas e Metalistas. A duração das políticas heterodoxas ou ortodoxas também variou muito. Ciclos longos de contenção foram sucedidos por fases curtas de emissionismo. A permanência ficava por conta de Sísifo e seus momentos de carregar o peso dos interesses das oligarquias rurais e da burguesia industrial ascendente nas costas, seguidos de desespero em observar toda a luta para a melhoria das condições socioeconômicas da maioria da população brasileira rolar ladeira abaixo.

Limitar os interesses das políticas Metalistas é empobrecer a análise do período. Gremaud afirma que:

Para a interpretação da política econômica da República Velha devemos levar em consideração, em primeiro lugar, a hegemonia da cafeicultura paulista, que se exprimia basicamente por meio da identificação dos problemas da cafeicultura como problemas nacionais, dada sua posição de destaque nas condições econômicas do Brasil. Porém existiam outros grupos de pressão, com força política 
variada, que também atuaram defendendo seus próprios interesses, os quais às vezes se compatibilizavam com os setores agrários... 236

E, segundo o autor, os outros grupos que defendiam as políticas ortodoxas seriam:

a) Os banqueiros internacionais e as empresas estrangeiras que operavam no Brasil, protegidos seja pela estabilidade cambial ou pelo cumprimento do receituário liberal da época, dando-lhes a segurança de que não haveria um default, como o ocorrido na Argentina;

b) Agentes econômicos internos com passivo em moeda estrangeira, entre eles os grandes importadores de mercadorias e as empresas concessionárias de serviços públicos, como as ferrovias, os serviços de energia e fornecimento de luz, a exploração de portos;

c) Parte da classe média urbana em ascensão, em especial àquela que se beneficiava da estabilidade interna dos preços;

d) O próprio Estado, pois a desvalorização cambial tem um efeito duplamente danoso ao Erário. Primeiro porque reduz drasticamente as importações, principal fonte de receitas de impostos na República Velha. Segundo pela razão de ver aumentar em moedas locais as dívidas e serviços das mesmas contraídas em mil réis e contos. ${ }^{237}$

Percival Farquhar pertencia aos agentes internos. Construiu ferrovias, portos, frigoríficos e recebeu várias concessões de serviços públicos. As políticas ortodoxas lhe interessavam. Seu inimigo não era a disputa Papelista e Metalista. Era a ascendente e oligopolista burguesia nacional. Nacionalista na exploração dos negócios; exploradora de um trabalho - muitas das vezes —, análogo à escravidão; crítica da concessão de monopólios a empresários estrangeiros, mas nunca aos seus próprios. Uma burguesia nacional moderna no discurso, provinciana nas ações e medieval nas relações sociais.

Por sua vez, as políticas heterodoxas interessavam a grupos distintos. A liberdade de emissão monetária, bem como a existência de livre concorrência entre as

\footnotetext{
${ }^{236}$ GREMAUD, Amaury Patrick. Das controvérsias teóricas à política econômica: pensamento econômico e economia brasileira no segundo império e na primeira república (1840-1930). Doutorado apresentado na Faculdade de Economia e Administração da USP. 1996. Página 182 e 183

${ }^{237}$ GREMAUD, Amaury Patrick. Das controvérsias teóricas à política econômica: pensamento econômico e economia brasileira no segundo império e na primeira república (1840-1930). Pág. 182
} 
casas bancárias colocavam os banqueiros nacionais como um dos grupos favorecidos pelas políticas econômicas mais flexíveis.

Os comissários que adiantavam o valor da safra aos cafeicultores também possuíam mais garantias e ganhos com o capital abundante do papel-moeda ( ou moedapapel num termo econômico mais exato).

Os importadores de bens de consumo, afinal em boa parte da República Velha esse mercado era controlado por produtos estrangeiros. Trazia vantagens para a grande maioria das classes médias urbanas e a população mais pobre como um todo, seja pelo barateamento dos bens de consumo, pela expansão do emprego com o crescimento do comércio, ou mesmo pelas tentativas industriais de substituição de importações.

Percival Farquhar também lucrava nos ciclos Papelistas, afinal além do crédito fácil, suas atividades dependiam da constituição de um mercado interno e a profusão de moeda-papel colaborava com isso.

E o Governo? Ganhava com o aumento da arrecadação provinda das importações. Lucrava ainda com o aquecimento dos investimentos em concessões públicas e obras públicas, seja por empresários nacionais ou estrangeiros.

Por último temos os cafeicultores. Estes, mesmo que as políticas de câmbio os desfavorecessem, eles possuíam um instrumento hábil de equilíbrio na lucratividade: a caneta da Lei. Empréstimos, Convênio de Taubaté, Caixa de Estabilização. O Estado estava a serviço de uma causa: a do café.

\subsubsection{O Café}

A literatura nos socorre novamente, nas sábias palavras de Lima Barreto:

As províncias da República da Bruzundanga, que são dezoito ou vinte, gozam, de acordo com a Carta Constitucional daquele país, da mais ampla autonomia, até ao ponto de serem, sob certos aspectos, quase como países independentes. (...)

Das províncias da Bruzundanga, aquela que é tida por modelar, por exemplar, é a província do Kaphet. Não há viajante que lá aporte, a quem logo não digam: vá ver Kaphet, aquilo sim! Aquilo é a jóia da Bruzundanga. ${ }^{238}$

\footnotetext{
${ }^{238}$ BARRETO, Lima. Os bruzundangas. Universidade da Amazônia/ Nead. Capítulo XX. 1917. Págs. 60-61
} 
O café é um exemplo do retumbante fracasso ou sucesso, dependendo da análise escolhida para representar a evolução do Capitalismo no Brasil da República Velha.

Um produto que destruiu matas, desgraçou solos, queimou oportunidades e vidas. Endividou o país e, muitas das vezes, atrasou o desenvolvimento industrial brasileiro. Uma riqueza de poucos barões e fazendeiros. E como estes detiveram o poder, oficialmente por 41 anos, transformaram o Estado num mero benfeitor de suas necessidades ( que por sinal eram insaciáveis).

$\mathrm{Na}$ época de preços altos no exterior, os cafeicultores e seus financiadores lucravam muito. Baixavam os preços internacionais, o Estado desvalorizava a moeda nacional, à custa de endividamento externo, da deflação e da carestia interna, pois prejudicava as importações num país com indústrias nascentes e dotado de um mercado interno dependente das mercadorias estrangeiras. Sendo a safra excessiva, o governo comprava os excedentes e os estocava inteligentemente ( na ótica do café), baixando os preços internacionais e garantindo a lucratividade de nosso "rei negro". Era preciso valorizar o café. Tudo era para servir ao senhor café e seus ilustres empresários. Era um capitalismo sem risco. Uma atividade econômica destituída de prejuízos.

Mas não foram os capitais do café; a ferrovia necessária para o escoamento do café e o mercado ampliado produzido pelo café que permitiram a industrialização brasileira, perguntam os incautos. Não seria o café o grande responsável pela nossa opulência e riqueza? Como queria Taunay:

Celebre phrase que o Brasil todo repetiu, tão lacônica quanto synthetica, proferiu Gaspar da Silveira Martins, no parlamento, pelas vizinhanças de 1880, procurando definir a economia nacional: o Brasil é o café e o café é o negro.

Nada mais conciso, nada mais proximo da verdade do que este conceito verdadeiramente lapidar. Realmente assim era: o grande esteio basico da economia do Brasil, o gênero de que, com enorme superioridade sobre os demais, elle dispunha para, manter o seu cambio internacional e poder figurar vantajosamente no rol das nações civilizadas pela comparticipação vultosa do commercio mundial era o café. $^{239}$

\footnotetext{
${ }^{239}$ TAUNAY, Affonso de E. Historia do café no Brasil. Volume nono: no Brasil República, 1889-1906 (Tomo I). Departamento nacional do café. Rio. 1939
} 
Os capitais provindos do café em boa parte foram engolidos pela inflação interna, pelos serviços da dívida externa e os constantes empréstimos obtidos junto aos bancos estrangeiros. Ferrovias de traçados incertos, bitolas diferentes em cada estado da nação que impediam as conexões ( a Ferrovia Sorocabana incorporada por Farquhar possuía 4 bitolas distintas em cerca de $1200 \mathrm{~km}$ de extensão). E desde quando as cervejarias, fábricas de tecidos, sapatarias e tantos outros setores industriais criados na República Velha possuíam alguma relação direta com o café. O historiador não pode observar a História apenas pelo líquido escuro e opaco do café.

Durante a segunda metade do século XIX, o café contou com condições e preços favoráveis no mercado internacional. O trabalho excessivo típico da expansão industrial das economias centrais aumentou o consumo do café, bebida revigorante e estimulante que é.

O fim da escravidão liberou capitais para investimentos na ampliação das áreas plantadas e no escoamento da safra pelos cafeicultores do Oeste Paulista. Junte-se a isso o baixo custo dos imigrantes. A desvalorização da moeda nacional no período Campos Salles/ Joaquim Murtinho, reduzindo os prejuízos advindos da queda nas cotações do café no mercado internacional, não impediram a crise de superprodução deflagrada de forma mais evidente na safra de 1906/07. Era necessário proteger nosso principal produto:

... Nesse contexto acorda-se o Convênio de Taubaté, uma tentativa bem sucedida de recuperação dos preços internacionais do café. O Convênio, embora celebrado entre 4 unidades da Federação (São Paulo, Minas Gerais, Rio de Janeiro e Espírito Santo), previa a criação da Caixa de Conversão, ou seja, a instauração da fixação da taxa nominal de câmbio. A efetiva criação da Caixa de Conversão pela União resultou das condições macroeconômicas impostas pelo Ministro Joaquim Murtinho, as quais lavaram a um processo de valorização da taxa nominal de câmbio entre 1898 e 1906, bem como da melhora do cenário internacional (Funding Loans, exportações de borracha e o próprio ingresso dos fluxos de financiamento do Convênio). A convergência entre as aspirações do Convênio (estabilizar a taxa nominal de câmbio) e os objetivos da política 
macroeconômica constituem um elemento de relevo na análise da política econômica da República Velha e da economia cafeeira. ${ }^{240}$

Na prática o Convênio de Taubaté (1906) permitia a compra do excedente de produção. Este excedente seria estocado em armazéns. Como o Brasil era responsável por $90 \%$ das exportações mundiais do café, os preços internacionais tenderiam a queda pela redução da oferta. A criação, 3 anos antes, dos títulos de crédito de warrant e conhecimento de depósito foram fundamentais para a estocagem. Observe-se a tabela abaixo dos preços médios da saca de café ( tendo como parâmetro o valor $100 \mathrm{em}$ 1995):

Tabela 6 - Estatísticas do Café. Valor Médio da Saca no Mercado Internacional

\begin{tabular}{|l|l|l|l|l|l|}
\hline Ano & Valor & Ano & Valor & Ano & Valor \\
\hline 1901 & 4,60 & 1912 & 12,93 & 1923 & 10,49 \\
\hline 1902 & 5,02 & 1913 & 10,31 & 1924 & 15,68 \\
\hline 1903 & 4,91 & 1914 & 8,19 & 1925 & 18,41 \\
\hline 1904 & 6,60 & 1915 & 6,30 & 1926 & 17,15 \\
\hline 1905 & 5,20 & 1916 & 7,46 & 1927 & 14,06 \\
\hline 1906 & 6,70 & 1917 & 7,38 & 1928 & 17,09 \\
\hline 1907 & 6,47 & 1918 & 8,42 & 1929 & 15,64 \\
\hline 1908 & 6,30 & 1919 & 17,72 & 1930 & 9,01 \\
\hline 1909 & 6,64 & 1920 & 11,51 & 1931 & 6,37 \\
\hline 1910 & 9,16 & 1921 & 7,61 & 1932 & 7,51 \\
\hline 1911 & 12,04 & 1922 & 10,97 & 1933 & 7,25 \\
\hline
\end{tabular}

Fonte: até 1939, preços médios de exportação de café do Brasil em mil-réis de IBGE (1986), convertidos em dólares através da taxa de câmbio da Tabela 10;1939-1947, IBC (1964); e a partir de 1948, IFS (2001).

Percebe-se que a valorização foi eficiente para elevar os preços. Entre 1906 e 1910 os preços de venda foram cerca de $30 \%$ maiores do que nos anos anteriores. Uma nova retração nos preços durante a Primeira Guerra obriga o governo a uma segunda valorização em 1917 ( ano da Revolução Russa e da Greve Geral no Brasil). Por 4 anos o valor da saca é valorizado.

\footnotetext{
${ }^{240}$ RIBEIRO, Fernando A política econômica e o convênio de Taubaté na economia cafeeira (1889-1906). Pesquisa \& Debate, SP, volume 22, número 1 (39) pp. 75-93, 2011 ( págs. 77-78)
} 
A recessão europeia do início dos anos 20 derruba o café novamente. A terceira valorização vem no ano de 1921. A política de valorização do café transforma-se em permanente em 1924, garantindo-se seus preços elevados até a Crise de 1929. Observese ainda que na década de 20, a saca de café atingiu seus maiores valores desde o Império e, na década seguinte os menores valores médios. Não se podia deixar de ser ufanista como Alfredo Ellis Jr:

Hoje a lavoura paulista de café é o maior centro agrícola do planeta, e o maior núcleo de trabalho agrícola organizado do mundo, é o maior repositório de energia rurais de todos os tempos, no globo, é a maior organização agrícola permanente que se tem visto. ${ }^{241}$

Segundo Almir Pita Freitas Filho ${ }^{242}$, com a manutenção dos lucros do setor cafeeiro, particularmente de São Paulo, pode este estado direcionar recursos para outras atividades. $\mathrm{O}$ surto industrial paulista daqueles anos parece estar vinculado à defesa do preço do café e à simultânea restrição de seu plantio. O plano de defesa contemplava os interesses da oligarquia cafeeira. Contraditoriamente, ao manter a lucratividade do café continuou atrativo para o mercado e, dessa forma, os investimentos em expansão da lavoura não cessaram reforçando a tendência à superprodução. As valorizações do café de 1906 a 1909 não resolveram o problema, apenas empurravam-no para o futuro. Duas novas valorizações foram necessárias, a primeira de 1917 e a segunda em 1921. A economia monocultora, a alta lucratividade garantida por lei, um Estado à serviço de uma classe econômica exigiam soluções mais drásticas: a partir de 1924 institui-se o Instituto Paulista de Defesa Permanente do Café, depois chamado de Instituto do Café. Os artigos $3^{\circ}$ e $7^{\circ}$ da Lei Estadual de São Paulo n ${ }^{\circ}$ 2004/1924, explicitam as medidas:

Artigo $3^{o}$ - Fica creada uma taxa de viação até o valor de um mil réis (ouro) ou o seu equivalente em papel, por sacca de café que tranzitar pelo territorio do Estado, a qual servirá para garantir o emprestimo que se realizar para instituir o fundo da defesa permanente do café.

(...)

Artigo 7. ${ }^{o}$ - Quando estiver organizado o fundo de que trata o artigo anterior, a defesa permanente do café consistirá ainda, em :

\footnotetext{
${ }^{241}$ ELLIS JR, Alfredo. Evolução da economia paulista e suas causas. Pág. 296

${ }^{242}$ FREITAS FILHO, Almir Pita. A política de defesa permanente do café na década de 1920 e o Instituto de Fomento e Economia Agrícola do Estado do Rio de Janeiro (1926-1931): notas para uma história institucional. Anais do XXVI Simpósio Nacional de História - ANPUH • São Paulo, julho 2011
} 
I - Emprestimos aos interessados, mediante condições de quantum, prazo e juros que forem determinados pelo Conselho, com garantia de café depositado nos armazens reguladores do Estado;

II - Compra de café no mercado de Santos e em qualquer outro mercado interno, para retirada provisoria, sempre que o Conselho julgar essa madida necessaria para a regularização da offerta ;

III - Serviço de informação, estatistica e propaganda do café para augmento de seu consumo e repressão das suas falsificações. ${ }^{243}$

Instituía-se um fundo de financiamento e empréstimo para o café. Garantia creditícia dos depósitos de café nos armazéns. Compra e retirada do mercado dos excedentes de produção. $\mathrm{O}$ “ rei negro” e seus senhores estavam à salvo.

\subsubsection{A Dívida Externa}

Segundo Levy \& Saes ${ }^{244}$ a historiografia brasileira tem repetido que os bancos estrangeiros no Brasil, antes da Primeira Guerra Mundial, não forneceram crédito às atividades produtivas, nem agrícolas nem industriais, limitando-se a financiar os investimentos de infraestrutura que facilitassem o escoamento dos produtos de exportação e a distribuição dos produtos manufaturados europeus.

Para os autores, os diversos estudos confirmam a hipótese de que os recursos provenientes da dívida externa quando foram utilizados para investimentos produtivos, destinaram-se ao financiamento de estradas de ferro, para serviços de infra-estrutura nas cidades ou nas obras públicas voltadas à logística da exportação. Dessa forma, historicamente, o endividamento externo foi um fator central nas dificuldades para o desenvolvimento do mercado interno, além de estabelecer uma profunda dependência do país com o capital financeiro internacional. Vista dessa maneira, nossa economia e nosso desenvolvimento teria sempre um caráter periférico e, quase sempre, interligado às economias centrais. Nos períodos de crise nas regiões desenvolvidas, sofriam as periféricas, econômica e financeiramente. ${ }^{245}$

Observe-se abaixo os dados da Dívida Externa:

\footnotetext{
${ }^{243}$ SÃO PAULO. Lei 2004/ 1924. Crea o instituto paulista de defesa permanente do café. ALESP.

${ }^{244}$ LEVY, Maria Barbara \& SAES, Flávio Azevedo Marques. Dívida externa brasileira, 1850-1913: empréstimos públicos e privados. Revista de História Econômica \& História de Empresas IV, I (2001 , 49-81). Pág. 51

${ }^{245}$ LEVY, Maria Barbara \& SAES, Flávio Azevedo Marques. Dívida externa brasileira, 1850-1913. Pág. 51
} 
Tabela 7 - Dívida Externa (milhares de dólares)

\begin{tabular}{|l|l|l|l|l|l|}
\hline Ano & Valor US\$1000 & Ano & Valor US\$ 1000 & Ano & Valor US\$ 1000 \\
\hline 1889 & 151,2 & 1903 & 332 & 1917 & 755 \\
\hline 1890 & 150,2 & 1904 & 340 & 1918 & 732 \\
\hline 1891 & 148,6 & 1905 & 379 & 1919 & 765 \\
\hline 1892 & 146,7 & 1906 & 426 & 1920 & 550 \\
\hline 1893 & 162,7 & 1907 & 444 & 1921 & 651 \\
\hline 1894 & 160 & 1908 & 542 & 1922 & 821 \\
\hline 1895 & 193,5 & 1909 & 553 & 1923 & 839 \\
\hline 1896 & 195,4 & 1910 & 625 & 1924 & 803 \\
\hline 1897 & 196,6 & 1911 & 643 & 1925 & 884 \\
\hline 1898 & 195,9 & 1912 & 641 & 1926 & 1022 \\
\hline 1899 & 204,2 & 1913 & 702 & 1927 & 1138 \\
\hline 1900 & 214,7 & 1914 & 786 & 1928 & 1241 \\
\hline 1901 & 292 & 1915 & 770 & 1929 & 1225 \\
\hline 1902 & 291 & 1916 & 771 & 1930 & 1294 \\
\hline
\end{tabular}

Fonte: IBGE. Estatísticas Históricas do Século XX

Muitos economistas e historiadores defendem o remédio amargo de Joaquim Murtinho e a tabela acima nos demonstra algo pouco estudado: o grau de endividamento externo do país após as medidas "saneadoras". Os valores da dívida entre 1898 e 1902 cresceram 48,54\%. Conclui-se, portanto, que os danos ao mercado interno, a recessão deflacionista não foram os únicos entraves ao desenvolvimento econômico do Brasil. Estendendo-se aos anos de 1902-1906 e depois 1909-1910, período em que tivemos o ministério da Fazenda de Leopoldo de Bulhões, adepto das políticas Metalistas, o crescimento da dívida atingiu 219,44\%. Em relação aos serviços da Dívida Externa, segundo dados do próprio IBGE passaram de US\$ 1.053 .000 anuais (1898) para US\$ 6.453.000 (1910). Ou seja, boa parte dos empréstimos tomados e dos saldos de balança comercial eram destinados ao pagamento dos serviços ou das amortizações da dívida externa, sobrando poucos capitais para os investimentos na produção interna.

Levy \& Saes, entretanto, relativizam essa condição periférica do capitalismo brasileiro e aventam a hipótese de que muitos empréstimos financeiros externos poderiam ter sido destinados aos setores privados.

...Tais empréstimos, portanto, contribuíram para promover o desenvolvimento do capitalismo, assim como da divisão internacional do trabalho, na qual cabia ao Brasil uma produção primário- 
exportadora. Cumpre indagar, no entanto, em que medida tais empréstimos foram efetivamente convertidos em investimentos produtivos, pois tais operações envolviam grandes riscos e podiam tornar-se fonte de grandes perdas. Em vários casos, o destino efetivo dos empréstimos podia ser diverso daquele apresentado no prospecto de lançamento dos títulos no mercado. Também há evidências de que, em vários casos, a colocação de um empréstimo representava mero esquema financeiro para atrair fundos disponíveis no mercado. ${ }^{246}$

$$
\text { (...) }
$$

os padrões de endividamento público e privado do Brasil entre 1850 e 1930 foram bem mais variados que a abordagem do tema sugere. Empresas privadas, inclusive industriais, obtiveram empréstimos diretamente nos bancos estrangeiros instalados no País e também tiveram a oportunidade de lançar títulos no mercado europeu. As grandes empresas ferroviárias, que, após o resgate promovido no governo Campos Sales, haviam sido arrendadas principalmente a empresas estrangeiras, obtiveram volumosos recursos no mercado europeu sob a forma de debêntures, frequentemente com o aval do Governo Federal. Governos estaduais e municipais também tiveram acesso ao mercado financeiro europeu, em grande parte com projetos pouco consistentes e com agentes financeiros nem sempre de grande responsabilidade.

Em que pesem a consistência das hipóteses levantadas, os estudos empíricos realizados ainda são insuficientes para se afirmar que os empréstimos estrangeiros serviram ao crescimento econômico brasileiro. Coincidentemente, Levy \& Saes terminam o artigo analisando o caso do empresário Percival Farquhar como paradigma dos empréstimos estrangeiros para que fossem revertidos na economia nacional. Antes de estudarmos o empresário americano, veremos os Relatórios Ministeriais produzidos entre 1898 e 1915. E tentar ouvir a voz dos ministros da Fazenda da República Velha, especialmente a do ministro Joaquim Murtinho.

\footnotetext{
${ }^{246}$ LEVY, Maria Barbara \& SAES, Flávio Azevedo Marques. Dívida externa brasileira, 1850-1913: empréstimos públicos e privados. Revista de História Econômica \& História de Empresas IV, I (2001 , 49-81). Pág. 76 a 80
} 


\section{CAPÍTULO 8 - OS RELATÓRIOS MINISTERIAIS}

Percival Farquhar viveu seu apogeu e queda no Brasil entre 1905-1914. Como veremos no capítulo seguinte. Entre 1915 e 1917, em meio à concordata da Brazil Railway e as outras empresas da holding do empresário americano, este ainda tentou sobreviver à frente dos negócios. Definitivamente afastado em 1919, Farquhar ainda retornou ao Brasil com dois projetos: o Itabira Iron entre 1921 e 1942 ( que na prática nunca foi efetivado) e seu último e menos ambicioso projeto ( entretanto o mais estratégico deles) o da Acesita ( 1944 a 1952). Sua participação no crescimento econômico e industrial do Brasil no primeiro quarto do século XX foi expressiva.

Neste último capítulo será apresentado um painel das principais discussões estabelecidas até aqui. Papelistas e metalistas; agraristas e industrialistas; nacionalistas e liberais. A fonte desse debate e dos ciclos que se interlaçaram em nossa economia são os Relatórios dos Ministros da Fazenda apresentados aos presidentes da República brasileira. Elenquei os relatórios entre os anos de 1898 e 1915.

O primeiro ano (1898) foi escolhido por trazer a visão predominante nesse período, a metalista do ministro Joaquim Murtinho, bem como as medidas decorrentes do $1^{\text {o }}$ funding loan. Desse ministro temos também a maior parte das interpretações, afinal as políticas econômicas posteriores em sua maioria procuraram seguir o remédio pouco homeopático receitado por Murtinho.

O momento derradeiro coincide com a "queda" de Farquhar ( 1915). São pronunciamentos oficiais, estatísticas econômicas e dados comparativos sobre as finanças brasileiras na República Velha. Um verdadeiro banquete de velhas ideias.

Tais relatórios encontram-se no Center for Research Libraries. Ligado a Global Resources Network, com sede em Chicago (Illinois-USA). Denominados de Brazilian Government Documents. Ministerial Reports ( 1821-1949). Ministério da Fazenda. Foram acessados por dezenas de vezes entre 2014 e $2016 .^{247}$

Cabe um adendo para pesquisadores interessados, entre outros documentos do governo brasileiro, temos na Instituição o levantamento dos seguintes ministérios: Agricultura ( anos de 1860-1960); Educação e Saúde Pública (1932); Guerra (18271939); Império(1832-1888); Indústrias, Viação e Obras Públicas (1893-1909); Instrucção Pública, Correios e Telégrafos ( 1891); Interior ( 1891-1892); Justiça (1825-

\footnotetext{
${ }^{247}$ Último acesso em 14 de novembro de 2016. Disponível em: 〈http://www-apps.crl.edu/brazil/ministerial/fazenda〉
} 
1928); Marinha (1827-1959); Relações Exteriores (1830-1960); Trabalho, Indústria e Comércio (1935-1947) e Viação e Obras Públicas (1909-1952).

\subsection{Joaquim Murtinho ${ }^{248}$ (ministro da Fazenda entre 1898 a 1902)}

Murtinho defendia que a crise econômica e financeira era causada pelo preço excessivo do café, com uma produção 'exagerada' em relação ao consumo. A crise não seria ocasionada pela decadência do trabalho ( os ex-escravos e imigrantes), como queria parte da elite produtora, mas na aplicação viciosa e constante dos capitais no café. Ao defender o eixo Metalista, o homeopata da República Velha o compara ao café:

... a crise financeira depende por sua vez, não tanto da diminuição da massa das rendas do estado, mas da reducção do valor da unidade dessa massa. Esta reducção é por seu turno a consequencia econômica, logica e forçada, da producção exaggerada do meio circulante em relação ao valor real da circulação. A crise financeira é, pois, não a expressão de uma grande decadência nas fontes de renda do estado, mas do regimen, que produzia a superabundância de papel-moeda no mercado.

(...) As duas crises são, perfeitamente semelhantes em sua expressão geral: superabundância de café em relação ao consumo, superabundância de papel-moeda em relação ao valor da circulação; abaixamento do preço do café, abaixamento do preço do papel-moeda; reducção do valor total da renda nacional, reducção do valor total das rendas do Estado

(...) As grandes emissões, que excitaram a febre de negocios, desenvolvendo os canaes da circulação monetaria, invadiram os campos, destruindo a calma, a prudência e a sabedoria no espirito dos

\footnotetext{
${ }^{248}$ Joaquim Duarte Murtinho ( * Cuiabá, 1848 e + Rio, 1911). Doutor em Medicina pela Faculdade do Rio de Janeiro e Lente do Curso de Ciências Naturais da Escola Politécnica. Engenheiro e médico homeopata com a mudança do regime ingressou na política. Entre 1896 e 1898 exerceu o cargo de Ministro da Indústria Viação e Obras Públicas. Ao assumir a pasta da Fazenda ( governo Campos Salles entre 1898 e 1902) atacou o problema do déficit: orçamentário mediante a emissão de papel-moeda ou empréstimos internos e externos. Criou uma combinação de fundos: $\mathrm{O}$ de resgate para reduzir anualmente o papel em circulação extinguindo o direito do Governo de emitir e o de garantia o direito do Governo de emitir e o de garantia constituído dos recursos obtidos com o restabelecimento da cota-ouro sobre os direitos de importação taxas arrendamentos e rendas eventuais arrecadadas em ouro. Consolidou-se a legislação sobre o Imposto de Consumo passando a quatorze os produtos sobre os quais devia incidir; restabeleceram-se as Coletorias Federais e deu-se maior eficiência à fiscalização e à arrecadação para incrementar as rendas. Foram anos de economias severas mas ao final de sua administração o País estava em condições de retomar o pagamento de seus compromissos ressurgiu o crédito a renda cresceu e o orçamento a apresentar saldos. Fonte: Galeria dos Ministros da Fazenda. Disponível em: 〈http://fazenda.gov.br/acesso-a-informacao/institucional/galeria-dos-ministros/pasta-republica/republica. $>$ Acessado em 7/11/2016.
} 
agricultores, infiltrando-lhes a ambição das grandes fortunas realizadas com grande rapidez... ${ }^{249}$

O pensamento de Murtinho desenvolve é centrado na lei da oferta e da demanda. Mais café sendo produzido, menos procura no mercado internacional, os preços tendem a cair, prejudicando a economia brasileira, pois este é responsável por quase três quartos de nossa renda. A lógica do papel-moeda seria a mesma: mais emissão, menos produtos e os preços inflacionam. Mais do que isso, por haver excesso de papel-moeda, abre-se espaço para especuladores que nada produzem, parte deles o ministro denominava de indústria artificial.

Para entender o conceito Metalista de Murtinho, é necessário saber o que era o papel-moeda para ele:

...o papel-moeda, exprime um titulo de credito, uma promessa de pagamento, uma especie de lettra descontada que se deposita na circulação monetaria do paiz (...)um valor potencial no momento de sua emissão, e esse valor potencial tende por sua vez a ser substituido por um novo valor real creado, ou ao contrario, a desapparecer. Si o papel emittido é empregado em trabalho productivo, a riqueza creada vem substituir o valor potencial do bilhete e há augmento verdadeiro da riqueza publica e particular, manisfestado por um desenvolvimento de circulação monetaria não só em sua extensão, mas tambem em seu valor real. (...) $\mathrm{Si}$, porem o emprego se faz em trabalhos improductivos, nenhum valor real será creado para substituir o valor potencial do bilhete, que assim desapparece, deixando uma circulação grande em sua extensão e pequena em seu valor real. ${ }^{250}$

Para Murtinho a emissão de papel-moeda forma negócios, alarga a circulação criando valores em potencial. Nessa condição se o trabalho criar novas riquezas, os valores monetários permanecem. Agora, caso as emissões fossem utilizadas para um trabalho improdutivo, em que nada seria criado, os papéis ficariam sem a correspondente produção. $\mathrm{O}$ valor da moeda desapareceria segundo ele, mas o papel permaneceria em circulação.

\footnotetext{
${ }^{249}$ Relatório do Ministério dos Negócios da Fazenda de 1898. República Federativa dos Estados Unidos do Brazil. Outubro de 1899. Imprensa Oficial. Rio. Ministro Joaquim Murtinho. Pág. III e IV

${ }^{250}$ Relatório do Ministério dos Negócios da Fazenda de 1898. República Federativa dos Estados Unidos do Brazil. Outubro de 1899. Imprensa Oficial. Rio. Ministro Joaquim Murtinho. Pág. VI
} 
A emissão do papel-moeda nem sempre, pois, é um mal; Ella póde ao contrario, representar um grande agente de progresso e prosperidade das nações. Tudo depende, como em todas as questões de credito, da moderação, da prudencia, do criterio com que se faz a emissão e do emprego productivo que della se faz, determinando a creação de novas riquezas, que valorizem a circulação augmentada pela emissão. ${ }^{251}$

Ou seja, apesar de crítico ao papel-moeda, ele deixa claro que não é contrário à sua necessidade numa economia capitalista. Bem aplicado, corretamente emitido, o papel pode ser um instrumento de desenvolvimento econômico.

Simpático ao papel-moeda se este resultar em atividade produtiva, Murtinho é taxativamente contrário ao mesmo em relação aos "erros" passados:

Nestas condições, a emissão de curso forçado traz em sua propria natureza os elementos de sua ruina. Os negocios inventados por Ella são em geral improductivos, e, quando os valores potenciaes dos bilhetes emittidos têm desapparecido, nenhum valor novo creado os vem substituir. ${ }^{252}$

Para ele, na República ( 1889 a 1897) as emissões foram em larga escala e a consequente redução do ouro no exterior foi constante. Denunciando o desastre da "superabundancia do papel inconversivel".

Murtinho afirma que em 1889, o papel-moeda inconversível era de 192 mil contos de réis, subindo para 297 mil réis em 1890; 513 mil réis em 1891; 561, 631, 712, 678, 711, 720 e 785 mil contos de réis, sucessivamente, até 1898. Num acréscimo de $408 \%$ em papel-moeda circulante, em apenas uma década. (página X. Relatório de $\left.1898^{253}\right)$.

$\mathrm{Na}$ monarquia, segundo ele, embora a emissão também fosse elevada e empregada em atividades improdutivas, o valor real foi mantido. Primeiro porque o ouro entrava em forma de empréstimos ou investimentos estrangeiros e segundo porque os valores potenciais desapareceram sem ser substituídos por valores reais.

\footnotetext{
${ }^{251}$ Relatório do Ministério dos Negócios da Fazenda de 1898. República Federativa dos Estados Unidos do Brazil. Outubro de 1899. Imprensa Oficial. Rio. Ministro Joaquim Murtinho. Pág.VII

${ }^{252}$ Relatório do Ministério dos Negócios da Fazenda de 1898. República Federativa dos Estados Unidos do Brazil. Outubro de 1899. Imprensa Oficial. Rio. Ministro Joaquim Murtinho. Pág. VIII

${ }^{253}$ As citações de menos de três linhas no texto, referentes aos relatórios serão indicadas apenas pela página e ano do Relatório. Quando se tratar de citações maiores, serão colocadas com o devido afastamento e a citação virá completa no rodapé.
} 
D'ahi o estabelecimento de industrias artificiaes e a organização agrícola para producção exaggerada do café, os dois factores da desvalorização da nossa produção. O emprego de capitaes e operarios em industrias artificiaes representa um verdadeiro esbanjamento da fortuna nacional. A renda dos productos dessas industrias só se faz afastando artificialmente do mercado productos similares estrangeiros... ${ }^{254}$

Para em seguir defender que os custos de produção numa economia com excesso de papel-moeda prejudica a todos:

O custo de producção nessas industrias, sendo muito alto em relação ao dos que nos vêm do exterior, eleva, por meio de taxas ultraproteccionistas nas tarifas da Alfandega, o preço dos productos estrangeiros, creando assim um mercado falso, em que os productos internos vencem na concurrencia os productos do exterior, todo consumidor é, pois, lesado, e a differença entre o que elle paga pelos objetos nesse regimen e o que pagaria em um regimen livre representa um imposto que lhe é arrancado para manutenção daquellas industrias. E, como o plantador de café e o productor de borracha, de matte, de algodão, que constituem nossa riqueza de exportação, são consumidores, não é difficil ver-se que no custo da producção de todos esses generos entra como elemento de depreciação esse imposto em favor das industrias artificiaes. ${ }^{255}$

Em resumo, para Murtinho a indústria artificial é prejudicial a todos. Primeiro, porque não produz algo de qualidade; segundo, por não ter preços competitivos; terceiro, porque ela retira capital de setores produtivos e rentáveis e último por serem todos consumidores, aqueles que produzem artificialmente ou não. Por este motivo, Murtinho estaria do lado dos agraristas, mas como vimos, ele não era totalmente contrário às atividades industriais.

Murtinho assustaria Delfim Netto ao afirmar que: “ o ideal econômico de um paiz não deve ser - importar pouco, mas importar e exportar muito" ( Relatório de

\footnotetext{
${ }^{254}$ Relatório do Ministério dos Negócios da Fazenda de 1898. República Federativa dos Estados Unidos do Brazil. Outubro de 1899. Imprensa Oficial. Rio. Ministro Joaquim Murtinho. Pág. XI

${ }^{255}$ Relatório do Ministério dos Negócios da Fazenda de 1898. República Federativa dos Estados Unidos do Brazil. Outubro de 1899. Imprensa Oficial. Rio. Ministro Joaquim Murtinho. Pág. XI
} 
1898. pág. XII). Segundo o ministro de Campos Salles, se utilizássemos o capital investido na denominada indústria natural, deixando de lado a artificial, a renda excedente conseguida pela exportação permitiria ao Brasil aumentar as suas importações.

Os capitais empregados na indústria artificial seriam então “ agentes parasitários da riqueza pública" ( Relatório de 1898. pág. XII). Por isso, segundo Murtinho, as emissões de papel-moeda ao criarem indústrias artificiais, diminuíram a riqueza nacional.

Murtinho apresenta a seguir medidas práticas para o aumento das exportações do café, denotando-se a visão elitista do ministro, separando os agricultores inteligentes dos rotineiros:

...a cultura em terrenos e climas superiores, por agricultores intelligentes e em boas condições economicas, outra representada pela cultura em terrenos e climas inferiores, por agricultores rotineiros e em más condições econômicas. (...) os capitaes e actividades empregados nesta segunda parte não são sómente estereis, são factores prejudiciaes à riqueza publica no momento actual, são agentes de destruição e não de producção de valores(...) as grandes emissões de papel-moeda foi um movimento brusco e desordenado, dando resultado numa producção de café excessiva em relação ao consumo actual. $^{256}$

Murtinho segue comparando o café ao excesso de papel-moeda. O exportador impõe um preço ao produtor de café, assim como o mercado financeiro impõe um preço ao importador. Todos perdem, menos os especuladores:

Armado do grande stock de café, o exportador não precisa comprar por algum tempo e impõe o preço ao productor, que acceita a imposição, não tendo elementos de resistência, pela necessidade em que esta de vender, sem demora, o seu producto.

Armado do stock do papel-moeda, o negociante de cambio não precisa comprar papel para pagamento da producção nacional, e póde por isso impor o preço ao vendedor do papel, isto é, ao importador, que acceita a imposição por não ter elementos de resistência, visto que

\footnotetext{
${ }^{256}$ Relatório do Ministério dos Negócios da Fazenda de 1898. República Federativa dos Estados Unidos do Brazil. Outubro de 1899. Imprensa Oficial. Rio. Ministro Joaquim Murtinho. Pág. XIV
} 
precisa vender o seu papel a troco de ouro para pagamento urgente nos mercados estrangeiros. O preço do café e do papel-moeda desceu (...) além dos effeitos naturaes da superabundancia dos gêneros, a acção, às vezes intensa e sempre funesta, da especulação. ${ }^{257}$

Explica, na visão Metalista, a origem dos déficits públicos:

A execução de serviços creados em leis especiaes e sem credito no orçamento, a pratica abusiva, em quase todas as nossas repartições, de excederem as verbas autorisadas por elle, os calculos optimistas no orçamento da receita, os abusos que se introduziram nas repartições arrecadadoras, forma outras tantas causas productoras dos déficits orçamentarios. Esses déficits soldaram-se ou por emissões de papelmoeda, produzindo todos os males que há pouco estudamos, ou por emprestimos internos e externos ${ }^{258}$

Internamente, a emissão de papel-moeda retira capitais do setor produtivo para imobilizá-los em títulos da dívida pública. E, dessa forma, aumentando a dívida externa e os juros. Murtinho critica as concessões públicas feitas pelo governo federal, tão importantes para Farquhar: " as estradas de ferro com garantia de juros que nos sugam e ainda nos hão de sugar” ( Relatório de 1898. Pág XIX). Nega a possibilidade dessas mesmas ferrovias em contribuírem para o desenvolvimento do país, seja por falta de renda para mantê-las, ou pela inexistência de um mercado interno, ou mesmo de passageiros para os vagões.

Na página XX ( Relatório de 1898) ele prossegue dizendo que o arrendamento das estradas, portos e ferrovias trouxe benefícios ao país e até são lucrativas, mas o capital destinado para a construção foi de tal monta que nunca será amortizado o seu valor. Além das ferrovias, diversas despesas desnecessárias tiraram a possibilidade de um equilíbrio orçamentário:

Juntem-se a isso as despezas militares com as guerras civis, o abuso das aposentadorias, o systema de montepios e caixas econômicas, em que as quotas e depositos são consumidos como rendas da União, augmentando dia a dia nossos compromisos, e ter-se-hão as causas principaes da situação que nos fez descer até a triste necessidade do

\footnotetext{
${ }^{257}$ Relatório do Ministério dos Negócios da Fazenda de 1898. República Federativa dos Estados Unidos do Brazil. Outubro de 1899. Imprensa Oficial. Rio. Ministro Joaquim Murtinho. Pág. XVII

${ }^{258}$ Ibid. Pág. XIX
} 
acorddo financeiro de 15 de junho do ano passado" ${ }^{259}$ [ o $1^{\circ}$ funding loan]

Murtinho prega contra o protecionismo ( Relatório 1898. pág. XXII), defendendo a lei econômica das vantagens comparativas. O protecionismo serviria ao produtor incompetente. Por exemplo, na cafeicultura: caso estivesse diante de um excesso de produtores de café em relação a um mercado limitado e o governo obrigasse aos cafeicultores uma redução da sua produção, " Seria a protecção aos inferiores à custa dos superiores, seria o socialismo aplicado à solução de um problema economico" ( Relatório 1898. pág. XXIII)

Para ele a valorização do café é tão complexa quanto a valorização do papelmoeda:

... o habito de ver o papel circular como uma moeda empresta-lhe um valor tão real para muitos, que temos visto entre nós homens eminentes por diversos titulos lamentar a destruição da fortuna publica ao receberem a noticia da incineração do papel de curso forçado. Para esses o papel-moeda nunca póde ser de mais, e a maior ou menos quantidade não influe sobre o valor da circulação ou sobre o cambio. Poderiamos assim, si semelhante opinião extravagante fosse verdadeira, emittir à vontade mais papel-moeda, que continuando com o mesmo valor que tem actualmente, nos forneceria os meios necessarios para satisfazer todos os nossos compromissos."

A visão econômica de Murtinho tem até um certo misticismo:

... o papel-moeda é um titulo de credito e, como tal, o seu valor depende da riqueza e da honestidade de quem o emitte. O numero de habitantes de um paiz não tem relacção directa, nem com a sua riqueza, nem com a sua honestidade, e não póde, por isso, determinar a capacidade emissora em relação ao papel-moeda. O numero de transacções está no mesmo caso, porque o credito não cresce com o

\footnotetext{
${ }^{259}$ Relatório do Ministério dos Negócios da Fazenda de 1898. República Federativa dos Estados Unidos do Brazil. Outubro de 1899. Imprensa Oficial. Rio. Ministro Joaquim Murtinho. Pág. XX

${ }^{260}$ Relatório do Ministério dos Negócios da Fazenda de 1898. República Federativa dos Estados Unidos do Brazil. Outubro de 1899. Imprensa Oficial. Rio. Ministro Joaquim Murtinho. Pág. XXIV
} 
numero de transacções; ao contrario, estas é que tem de subordinar-se ao credito. ${ }^{261}$

Defende suas posições Metalistas ao criticar a necessidade de papel-moeda para suprir a imigração e a libertação dos escravos, aplicada anteriormente. O resultado dessa medida, segundo ele, é que as emissões foram tão grandes que o valor atual ( de 1898) seria semelhante aos do fim da monarquia. O poder de emitir não deveria vir acompanhado do poder de dar um valor fictício às emissões. Só se corrige isso, com a política inversa, ou seja, o Metalismo (Relatório 1898. Pág. XXVII)

A especulação é o cerne do comércio (Relatório 1898. pág. XXXIV). E como tal, segundo o matogrossense, um meio parasitário. A especulação brasileira do início da República seria consequência dos excessos de produção do café e da emissão do papel-moeda. Tirando-se os excessos, acabaria a especulação:

A regulamentação do commercio de cambio nada tem produzido de positivo, a especulação é um Protheu; a cada novo regulamento elle responde tomando formas novas, e, quando se suppõe que vai extinguir-se, surge cheio de vida, demonstrando que os regulamentos nada podem contra a sua essência, que é o próprio commercio, nem contra a sua modalidade, que é a expressão de um vicio econômico. Podemos e devemos legislar para auferir desse commercio, altamente lucrativo, rendas para o Thesouro." 262

No relatório de 1899 ele afirma que a produção de café caiu por seleção natural (pág. III). E, claro, com suas medidas anteriores que diminuíram os impostos do produto na França e Itália, produzindo um aumento das exportações para aqueles países. O resultado foi decorrência da política econômica: o preço do café subiu no mercado internacional, trazendo mais riquezas para o Brasil.

Tece as primeiras observações sobre o funding loan de 1898:

A diminuição na massa de papel-moeda circulante e o augmento do valor da nossa exportação representam os elementos materiaes daquela alta [do preço do café]. O resurgimento do nosso credito, a confiança despertada pela fidelidade com que cumprimos os nossos

\footnotetext{
${ }^{261}$ Relatório do Ministério dos Negócios da Fazenda de 1898. República Federativa dos Estados Unidos do Brazil. Outubro de 1899. Imprensa Oficial. Rio. Ministro Joaquim Murtinho. Pág. XXV

${ }^{262}$ Idem, ibidem. Pág. XXXVII
} 
contractos e executamos um programma de administração honesta e economica, representam os elementos moraes. ${ }^{263}$

Prega contra a regulamentação do câmbio, pois haveria diversas formas de se especular, dificultando a separação do negócio legítimo do falso. Diz o homeopata: ...o único remédio de effeitos radicaes, duradouros e permanentes capazes de eliminar os abusos da especulação está na reducção gradual e continua do papel-moeda em circulação, até que entremos no regimen da conversibilidade ou, pelo menos, até que o papel restante, convertido ao câmbio de $24 \mathrm{~d}$, produza em ouro o valor da nossa exportação. É para este desideratum que deve convergir todos os nossos esforços. ${ }^{264}$

Os resultados apresentados são expressivos. Em 1898 ele cita 3093 novos registros comerciais, quase o dobro do ano anterior (pág, 122). Numa tentativa de negar a recessão causada pela política restritiva. Nas casas mercadoras de um só produto, por exemplo, constituíram-se: 1496 novas lojas de bebidas, 1033 de fumo, 228 de calçados, 108 de perfumarias, 94 de especialidades farmacêuticas e 4 de velas. ( pág. 123)

No Relatório de 1900, Murtinho elenca os fatores para o equilíbrio financeiro do país: o empréstimo do funding loan, o arrendamento das estradas de ferro ( o qual ele criticara em 1898, mas passou a defender a partir de 1900, abrindo espaço para a entrada de Farquhar no país) e os pagamentos de dívidas ao tesouro feito pelos bancos. As novas medidas adotadas por ele agilizaram a:

...cobrança em ouro de uma parte dos direitos aduaneiros para cobrir nossas despezas na mesma especie no exterior e no interior; resgate em ouro das dividas externa e interna; creação de uma caixa de resgate da divida interna do papel; desenvolvimento dos impostos de consumo; melhoramento da arrecadação das rendas aduaneiras pelos factores consulares, e, pelo convenio com os Estados, das rendas internas com a creação de collectores federaes; desenvolvimento do imposto do sello por medidas mais garantidoras dos direitos da União; a mais severa economia publica pela supressão de serviços inuteis ou pouco urgentes; transformação de fontes de deficit em fontes de renda

\footnotetext{
${ }^{263}$ Relatório do Ministério dos Negócios da Fazenda de 1899. República Federativa dos Estados Unidos do Brazil. Outubro de 1900. Imprensa Oficial. Rio. Ministro Joaquim Murtinho. Pág.VIII

${ }^{264}$ Relatório do Ministério dos Negócios da Fazenda de 1899. República Federativa dos Estados Unidos do Brazil. Outubro de 1900. Imprensa Oficial. Rio. Ministro Joaquim Murtinho. Pág.IX
} 
com o arrendamento das estradas de ferro; liquidação de compromissos avultados oriundos de guerras civis e de concessões feitas pelo primeiro governo da Republica; incorporação ao patrimonio nacional, sem novos ônus, antes com vantagens, das estradas de ferro estrangeiras que gosam de garantia de juros; e finalmente a creação da Estatistica Commercial que, fornecendo aos Poderes Publicos os dados necessarios, habilita-os a formular e executar os seus planos financeiros e economicos, julgando com segurança os effeitos colhidos pela nação."265

Ou seja, sua administração encontrou novas formas de arrecadação e ao mesmo tempo modernizou a contabilidade no país. Murtinho diz a seguir que a nossa única fonte de recursos é o imposto. E denomina de impostos os empréstimos estrangeiros (como os do funding), pois estes nada mais seriam do que adiantamentos de tributos: que os recursos provenientes do arrendamento de uma estrada de ferro são simplesmente os juros de capitaes oriundos de impostos que foram cobrados para a sua construção(...)os recursos fornecidos para pagamento das dividas dos institutos bancarios são valores emprestados aos bancos pelo governo, que os teve por meio de impostos."266

Murtinho defende a presença do capital estrangeiro, essenciais ao nosso desenvolvimento: “... [duas companhias inglezas] offereciam maiores garantias ao arrendamento das outras, que os nacionaes...” (Relatório 1901. página XXVI.)

Nas páginas XXXIII a XXXVI ( Relatório de 1901), Murtinho apresenta uma longa lista com preços de mercadorias entre 1899 a 1901. Seu objetivo era estancar as críticas de que o Metalismo trouxera a inflação, pois vários deles como o queijo, o tabaco, o açúcar, os químicos, o leite e o fumo, baixaram naquele período. O governo aumentou sim os impostos, reconhece ele, mas não o aplicou medidas improdutivas, como anteriormente se fazia. Afirma ainda que:

...são raros os objectos cujos preços se elevaram, e entre esses se destacam o feijão e o milho nacionaes, sobre os quaes não pesam impostos federaes e aos quaes se protegeu com tarifas especiaes. A

\footnotetext{
${ }^{265}$ Relatório do Ministério dos Negócios da Fazenda de 1900. República Federativa dos Estados Unidos do Brazil. Outubro de 1901. Imprensa Oficial. Rio. Ministro Joaquim Murtinho. Págs. XII e XIII

${ }^{266}$ Ibid. Pág XV
} 
grande maioria dos objectos tem hoje os seus preços diminuidos; e a explicação da grande carestia da vida, pela enorme elevação de preços, não passa de um recurso da opposição.É nesse terreno dos factos e dos numeros que esta questão deve ser debatida; é neste terreno que os nossos adversarios devem vir demonstrar as suas asserções; aqui as demonstrações não se fazem com declamações mais ou menos sonoras, mas com o rigor dos numeros e a eloquencia dos factos.",267

Reafirma a necessidade da construção de obras públicas como portos e ferrovias. Dá destaque para o porto de Rio, que acabará anos depois nas mãos de Farquhar. (Relatório de 1900. pág. LIV)

No ano de 1901 ( seu último relatório), Murtinho apresenta um balanço geral de receitas e despesas ${ }^{268}$ :

Tabela 8 - Receitas de 1899 a $1901^{269}$

\begin{tabular}{|c|c|c|}
\hline \multicolumn{3}{|c|}{ RECEITAS 1899 a 1901} \\
\hline \multicolumn{3}{|l|}{ Ordinarias } \\
\hline Importação & $197.807: 143 \$ 435$ & \\
\hline Entrada e sahida e estadia de navios & $453: 908 \$ 407$ & \\
\hline Addicionaes & $186: 673 \$ 810$ & \\
\hline Interior & $75.577: 705 \$ 024$ & \\
\hline Consumo & $24.593: 490 \$ 265$ & 298.620:976\$041 \\
\hline Extraordinaria & & $19.607: 458 \$ 385$ \\
\hline \multirow[t]{2}{*}{ Depositos ( saldo) } & & $15.522: 622 \$ 102$ \\
\hline & & $333.751: 051 \$ 428$ \\
\hline \multicolumn{3}{|l|}{ Operações de Credito } \\
\hline Emissão de moedas de nickel & $810: 000 \$ 000$ & \\
\hline Dita do funding loan & $25.846: 459 \$ 813$ & \\
\hline Dita do empréstimo de 1895 & $10: 656 \$ 667$ & \\
\hline $\begin{array}{l}\text { Pagamento realizado pelo Banco da Republica, nos } \\
\text { termos da Lei n. } 2565 \text { de } 29 \text { de maio de } 1875 \text { e decreto } \\
\text { legislativo n. } 183-\text { C de } 23 \text { de setembro de } 1893\end{array}$ & 1.130:000\$000 & \\
\hline \multicolumn{3}{|l|}{ Auxilios à Lavoura } \\
\hline $\begin{array}{l}\text { Pagamento feito pelo Banco da Lavoura e do } \\
\text { Commercio do Brasil }\end{array}$ & $2.022: 944 \$ 180$ & \\
\hline \multirow[t]{2}{*}{ Idem pelo Banco de Credito real de Minas Geraes } & $480: 173 \$ 343$ & $30.330: 246 \$ 003$ \\
\hline & & $364.081: 297 \$ 431$ \\
\hline Saldo do Exercicio de 1895 & & $206.654: 888 \$ 142$ \\
\hline TOTAL DA RECEITA & & $570.736: 185 \$ 572$ \\
\hline
\end{tabular}

\footnotetext{
${ }^{267}$ Relatório do Ministério dos Negócios da Fazenda de 1900. República Federativa dos Estados Unidos do Brazil. Outubro de 1901. Imprensa Oficial. Rio. Ministro Joaquim Murtinho. Pág. XXXVII

${ }^{268}$ Relatório do Ministério dos Negócios da Fazenda de 1901. República Federativa dos Estados Unidos do Brazil. Outubro de 1902. Imprensa Oficial. Rio. Ministro Joaquim Murtinho. Pág. V

${ }^{269}$ As duas tabelas a seguir ( a 7 e a 8) foram reproduzidas na íntegra e respeitando-se todas as divisões e textos.
} 
Tabela 9 - Despesas de 1899 a 1901

\begin{tabular}{|c|c|c|}
\hline \multicolumn{3}{|c|}{ DESPEZA 1899 a 1901} \\
\hline Ministerio da Justiça e Negocios Interiores & $21.417: 481 \$ 500$ & \\
\hline $\begin{array}{ll}\cdot & \text { das Relações Exteriores } \\
\end{array}$ & $1.448: 521 \$ 211$ & \\
\hline Marinha & $186: 673 \$ 810$ & \\
\hline Guerra & $21.684: 283 \$ 679$ & \\
\hline Industria, Viação e Obras Publicas & 47.483:594\$732 & \\
\hline Fazenda & $128.817: 382 \$ 732$ & 297.935:616\$293 \\
\hline \multicolumn{3}{|l|}{ Operações de Credito } \\
\hline Resgate de papel-moeda & $47.448: 625 \$ 000$ & \\
\hline Dito de bonus & $1: 000 \$ 000$ & \\
\hline $\begin{array}{l}\text { Dito de papel-moeda, nos termos da lei n. } 2565 \text {, de } 29 \text { de } \\
\text { maio de } 1875 \text { e decreto legislativo n. } 183-C \text { de } 23 \text { de } \\
\text { setembro de } 1893\end{array}$ & 1.180:000\$000 & \\
\hline TOTAL DA DESPEZA & $346.215: 242 \$ 293$ & \\
\hline Comparando-se a Receita na somma de & $570.736: 185 \$ 573$ & \\
\hline Com a Despeza na de & $346.736: 185 \$ 576$ & \\
\hline $\begin{array}{l}\text { Resulta o saldo, que passa para o exercício de } 1901 \text {, } \\
\text { sujeito ainda a pequenas alterações, na importância de }\end{array}$ & $224.520: 948 \$ 280$ & \\
\hline
\end{tabular}

Observa-se que o saldo favorável foi bastante substancial, mais de 224 mil contos de réis. As receitas advindas do funding loan totalizaram pouco mais de $5 \%$. Ao que tudo indica, as política restritivas de Murtinho surtiram o efeito ( financeiro) esperado. Interessante notar que outro "vilão" das contas públicas, nos discursos de época e análises posteriores, parece não corresponder a realidade das contas públicas, afinal as despesas dos ministérios da Marinha e da Guerra somadas custavam 7\% de nosso orçamento, o mesmo gasto do ministério da Justiça e muito menos do que o maior responsável pelas nossas despesas públicas no período: o próprio ministério da Fazenda com cerca de $43 \%$ do total. Fica claro aqui que os empréstimos e saldos em contas serviam para pagar as dívidas antigas. A Viação e Obras, com quase $14 \%$ das despesas mostrava que o país realmente investia pouco de seu orçamento em melhorias públicas.

8.2. Leopoldo de Bulhões ${ }^{270}$ ( ministro da Fazenda entre 1902-1906/ 1909-1910)

\footnotetext{
${ }^{270}$ José Leopoldo de Bulhões Jardim ( * Goiás.1856, + Petrópolis.1928). Formado em Ciências Jurídicas e Sociais pela Universidade de São Paulo. Foi Deputado em diversas legislaturas; Senador; Presidente da Associação Comercial; Presidente do Conselho de Contribuintes do Imposto de Renda. Nomeado Ministro da Fazenda por Rodrigues Alves entre 1902 e 1906 consolidou a obra de seu antecessor, Joaquim Murtinho. Encerraram-se os orçamentos com saldo e a massa de papel-moeda decresceu gradativamente. No primeiro período de sua administração destacaram-se: Regulamentação do funcionamento e fiscalização das companhias estrangeiras tendo sido criada a Inspetoria de Seguros do Tesouro Nacional; reorganização da Casa da Moeda e das Delegacias Fiscais nos Estados; liquidação do Banco da República do Brasil e aprovação dos Estatutos do Banco do Brasil; novo regulamento de loterias; elaboração do projeto do Código de Contabilidade Pública. Em 1907 assumiu a Diretoria do Banco do Brasil. Voltou a ocupar o cargo de Ministro da Fazenda entre 1909 e 1910 na Presidência de Nilo Peçanha. Nesse período promoveu grande reforma no Ministério e aprovou o regulamento dos concursos para ingresso no serviço fazendário. Fonte: Galeria dos Ministros da Fazenda. Disponível em: <http://fazenda.gov.br/acesso-a-informacao/institucional/galeria-dos-ministros/pastarepublica/republica. $>$ Acessado em 7/11/2016.
} 
À página IX ( Relatório de 1902), Bulhões descreve o avanço da dívida externa. Era de 34.310.400 libras antes do funding, atingindo 62.520.497 libras em outubro de 1902, sem contar o empréstimo de 3.388.100 libras da Companhia Estrada de Ferro de Minas. Lembrando que o funding suspendeu o pagamento dos serviços por 10 anos. Pergunta-se aqui sobre a realidade do auto-proclamado sucesso de Joaquim Murtinho nas contas públicas. Belo discurso, mas práticas não condizentes.

As retiradas de papel-moeda, a grande medida Metalista no período de $1^{\circ}$ de setembro de 1898 a 31 de maio de 1903, foram de um valor nominal de 113.018:619\$500 ( cerca de 14,39\% do meio circulante). ( Relatório de 1902. Pág. II)

Nas páginas III e IV, Bulhões apresenta o saldo de 1902 entre receitas 316.503:093\$113 para uma despesa de 251.737:709\$208. Ou seja, as alegações constantes de déficits públicos como justificativa para medidas restritivas e recessivas não se confirmam pelos próprios pares. Fato já visto na Tabela 8.

Nos dois primeiros anos de relatório, Bulhões limita-se a elogiar as medidas tomadas por Murtinho e reafirma a necessidade de se seguir as medidas Metalistas.

Bulhões defende um protecionismo moderado em nossa economia ( Relatório de 1903. Pág. VIII), pois a União depende de impostos aduaneiros ( $60 \%$ do total). Subir as taxas de importação seria reduzir as receitas, pois nosso mercado interno não cresce no mesmo ritmo. Bulhões cita uma grande fonte de despesas: as sentenças judiciais contrárias à Fazenda e defende mudanças na lei.

Refiro-me à execução de sentenças contrarias à Fazenda Nacional que, no regimen creado pelas divergências dos julgados, esta em posição subalterna a qualquer outra parte vencida em acção regular (...) Abolido o contencioso administrativo, não ha motivo para limitar os meios de defesa de que possa usar a União, quando vencida em litígio perante o Poder Judiciario, no exercicio da ampla attribuição que a este confere a Constituição Federal. ${ }^{271}$

Bulhões estava preocupado com questões burocráticas e defende em 1904:

(...) a adopção do Codigo de Contabilidade. O projeto (...) de 29 de dezembro de 1902, consolidou as disposições relativas à

\footnotetext{
${ }^{271}$ Relatório do Ministério dos Negócios da Fazenda de 1902. República Federativa dos Estados Unidos do Brazil. Outubro de 1903. Imprensa Oficial. Rio. Ministro Leopoldo de Bulhões. Pág. XXVI
} 
Contabilidade, esparsas em leis orçamentárias e especiaes, completando-as, harmonizando-as, dando-lhes unidade. ${ }^{272}$

Bulhões lutava contra uma velha conhecida da economia federativa brasileira, a "guerra fiscal":

A questão da arrecadação de impostos de importação pelos Estados é uma das mais graves que affectam o nosso organismo administrativo. $\mathrm{O}$ art $5^{\circ}$ do regulamento promulgado pelo decreto n.5402, de 23 de dezembro de 1904, determina que a arrecadação de taes impostos será feita pelas alfândegas e mesas de rendas federaes. O Governo de alguns Estados, como o de Minas Geraes e do Rio de Janeiro, os cobram, entretanto, nas suas respectivas estações fiscais... ${ }^{273}$

Compara nosso federalismo com o dos Estados Unidos:

(...) consenso geral da doutrina e com a demonstração historica nos Estados Unidos da America do Norte, de ser o livre intercambio estadoal um dos segredos de sua pujante expansão economica, entre nós a livre permuta interestadoal se haja nutrido até hoje sómente de applausos theoricos, quando se devera já ter trabalhado por tornar realidade o principio das fronteiras abertas entre os Estados. ${ }^{274}$

Bulhões ressalta a situação financeira do país em fins de 1905 de forma positiva. Segundo ele, a ação de forças orgânicas que harmoniosamente e concomitantemente agem sobre a sociedade como um todo:

Restabelecida a segurança nas relações internacionaes; arredada pela nova politica qualquer possibilidade de conflictos com as nações vizinhas; resolvido o problema do Acre pelo Tratado de Petropolis; paga à Bolivia a indemnisação de 2 milhões de libras; liquidada as questões das grandes emprezas ferroviárias Oeste de Minas e Sorocabana e da empreza de navegação do Lloyd, devedoras ao Thesouro e ao Banco da Republica; diminuídos, com as encampações de estradas de ferro, onerosos compromisso da Nação; amortizada em

\footnotetext{
${ }^{272}$ Relatório do Ministério dos Negócios da Fazenda de 1903. República Federativa dos Estados Unidos do Brazil. Outubro de 1904. Imprensa Oficial. Rio. Ministro Leopoldo de Bulhões. Pág. XVI

${ }^{273}$ Relatório do Ministério dos Negócios da Fazenda de 1904. República Federativa dos Estados Unidos do Brazil. Outubro de 1905. Imprensa Oficial. Rio. Ministro Leopoldo de Bulhões. Pág. XII

${ }^{274}$ Ibid. Pág. XIV
} 
somma apreciável a divida publica consolidada interna e externa e a divida fluctuante; reduzida a massa de papel-moeda em circulação; feitas as operações de credito necessarias às obras do porto e ao definittivo saneamento do Rio de Janeiro - surgio espontaneamente, como resultado desses factores, a confiança, o restabelecimento do credito publico. ${ }^{275}$

Leopoldo de Bulhões, como vimos na passagem acima, será fundamental para a entrada de Farquhar no Brasil. A defesa do sistema de concessões, a simpatia com o capital estrangeiro são marcas do ministro de Rodrigues Alves. Não vê contradições entre a Lavoura e a Indústria.

Bulhões volta a elogiar Murtinho (Papelismo) em seu último relatório:

Restringida assim a circulação fiduciaria, creada a receita em ouro para as despezas nessa especie, equilibrados os orçamentos, instituídos os fundos de garantia e de resgate, estabelecida no Banco da republica sob a immediata direcção do Governo, a carteira cambial, actuando de par com essas medidas o progressivo augmento da nossa exportação, o cambio que em 1898 havia cahido a 5 (5/81) elevou-se a 7 e 9 e veio fixar-se em 12 em 1903 e 1904. Prosseguimos com firmeza nesta política, imprimindo maior vigor ao funccionamento destes apparelhos... ${ }^{276}$

Bulhões afirma que apesar dos esforços impostos, os benefícios a compensaram. Mas a pergunta que fica: todos saíram ganhando? mas e a população brasileira dos setores médios e mais pobres? A política Metalista incomodava a Lavoura, por isso a oposição segundo ele. "E sera em nome de toda a lavoura que se pede o abandono das boas doutrinas, que não são novas, que estão consagradas pela autoridade dos mestres e experiencia das nações, que zelam o seu credito?" ( pág VII. Relatório de 1905). Para ele, a oposição ocorria para defender os cafeicultores que sugavam o Estado: "Um paiz não pode se submeter a uma classe."

Bulhões tem medo da volta do Papelismo e sua política emissionista, com a criação da Caixa de Conversão ( 1906):

\footnotetext{
${ }^{275}$ Relatório do Ministério dos Negócios da Fazenda de 1904. República Federativa dos Estados Unidos do Brazil. Outubro de 1905. Imprensa Oficial. Rio. Ministro Leopoldo de Bulhões. Pág. XXIV

${ }^{276}$ Relatório do Ministério dos Negócios da Fazenda de 1905. República Federativa dos Estados Unidos do Brazil. Outubro de 1906. Imprensa Oficial. Rio. Ministro Leopoldo de Bulhões. Pág. V
} 
...este projeto visa realmente o resurgimento do papelismo sob a fôrma do regimen conversivel, - a elevação da massa de papel de 600, que é actualmente, a 900 mil contos, - a volta ao regimens das emissões, cujos desastres ainda perduram na carestia da vida, na taxa de cambio, na incerteza dos negocios, desastres cujas consequências oito annos de pesados ônus e grandes sacrifícios impostos à Nação mal puderam attenuar. ${ }^{277}$

Diz ainda que a Caixa de Conversão é um risco, pois:

A caixa que se vae crear é denominada — de conversão, mas — de emissão será pela força das cousas e de emissão inconversível, porque o fraco lastro de que podera dispor não resistirá à pressão de necessidades que para logo hão de surgir, absorvendo-a por completo. Quando ainda estamos no regimen da moratoria de 1898 (...) sujeitas ao funding loan, fazer-nos voltar à politica financeira condemnada, inutilisar todo o aturado e pertinaz esforço de oito annos de duras provações... $^{278}$

Além da tentativa ( infrutífera até hoje) de criar o Código de Contabilidade, Bulhões, na tentativa de modernizar o meio circulante brasileiro, conseguiu aprovar a lei de criação do cheque. Pois este título de crédito é um "instrumento de maior efficacia para o desenvolvimento das transacções", pois o mesmo põe" ...o sacado ao abrigo das surprezas por parte do portador, e ao mesmo tempo cercando de garantias o sacador, o endossante e quantos figurarem no título." ${ }^{279}$ Bulhões foi muito mais técnico do que Murtinho, bastante preocupado com questões do bom serviço público e da burocracia administrativa.

8.3. David Campista ${ }^{280}$ ( ministro da Fazenda de 1906-1909)

\footnotetext{
${ }^{277}$ Relatório do Ministério dos Negócios da Fazenda de 1905. República Federativa dos Estados Unidos do Brazil. Outubro de 1906. Imprensa Oficial. Rio. Ministro Leopoldo de Bulhões. Pág. XIV

${ }^{278}$ Relatório do Ministério dos Negócios da Fazenda de 1905. República Federativa dos Estados Unidos do Brazil. Outubro de 1906. Imprensa Oficial. Rio. Ministro Leopoldo de Bulhões. Pág. XIV

${ }^{279}$ Ibid. Pág. XXIX

${ }^{280}$ David Morethson Campista (* Rio, 1863 e + Dinamarca, 1911). Bacharelou-se em Direito pela Universidade de São Paulo (1883). Deputado Federal. Em 1898 assumiu o cargo de Secretário das Finanças de Minas Gerais. Nomeado Ministro da Fazenda por Afonso Penna. foi um de seus primeiros atos: a criação da Caixa de Conversão para a qual foram transferidos os fundos de resgate e de garantia do papel-moeda instituídos em 1899. Nesse período cunharam-se as moedas de prata de dois mil um mil e de quinhentos réis; sancionou-se o decreto legislativo definindo a letra de câmbio e a nota promissória; regularam-se as operações cambiais; autorizou-se empréstimo para ocorrer às despesas com os serviços de água da Capital da República e construção de vias férreas bem como a emissão de apólices para a construção da Estrada de Ferro Madeira-Mamoré. Ao deixar o Ministério foi
} 
O ministério de Afonso Penna era pejorativamente denominado de "Parque de Diversões", pois os ministros eram considerados muito jovens para exercer o cargo. Campista estava com 43 anos quando assumiu a pasta da Fazenda. Sua primeira ação combatia os Metalistas predominantes entre 1898 e 1906. Criou a Caixa de Conversão em 1906 e permitiu várias concessões públicas de ferrovias e serviços públicos ( entre elas a Ferrovia Madeira-Mamoré de Farquhar).

Nada justifica semelhante affirmativa [ as críticas de Bulhões](...) Sem duvida se poderá observar que a experiência ainda curta desse mecanismo financeiro não autoriza conclusões definitivas em favor delle. Houvesse, porém, a Caixa de Conversão exhibido até hoje os seus cofres virgens de depositos e tal facto seria assignalado como consagração victoriosa de opiniões autorisadas. Que asseguravam resolutamente que jamais ouro algum procuraria a Caixa." 281

Percebe-se que Campista era mais político do que economista, pois dizia sem quase nada revelar. Segundo ele, políticas como o funding loan eram bem sucedidas não pela boa administração, mas porque " a atração de capitaes pode estar nas garantias reais humilhação do paiz ( Relatório 1906. pág. XV). Depois Campista nega que a Lavoura ( o café) necessita de uma moeda desvalorizada. “ Nem a alta nem a baixa, o mal é a constante oscilação” (Relatório 1906 pág. XVI). Um dos efeitos esperados pelo Convênio de Taubaté ( 1906) “..é justamente o augmento do valor das exportações pela valorisação do café...” ( Pág. XXII. Relatório de 1906). Resumindo:

O que a lavoura precisa, como precisam o commercio, a industria e todas as forças productoras da nação, é libertar o trabalho dessa especulação forçada em que se agita, dessa insegurança enervante que decorre, como effeito necessario, ds fluctuaçóes cambiaes. ${ }^{282}$

Nas páginas XXVI e XXVII (Relatório de 1906), Campista elenca alguns fatores em defesa da Caixa de Coversão:

\footnotetext{
nomeado representante diplomático do Brasil na Dinamarca onde faleceu. ( Fonte: Galeria dos Ministros da Fazenda. Disponível em: < http://fazenda.gov.br/acesso-a-informacao/institucional/galeria-dos-ministros/pasta-republica/republica. $>$. Acessado em $7 / 11 / 2016)$

${ }^{281}$ Relatório do Ministério dos Negócios da Fazenda de 1906. República Federativa dos Estados Unidos do Brazil. Outubro de 1907. Imprensa Oficial. Rio. Ministro Dr.David Campista. Pág. V

${ }^{282}$ Relatório do Ministério dos Negócios da Fazenda de 1906. República Federativa dos Estados Unidos do Brazil. Outubro de 1907. Imprensa Oficial. Rio. Ministro Dr.David Campista. Pág. XVI
} 
I) As oscilações do câmbio são péssimas para o balanço de pagamentos, desorganizam a economia e forçam a especulação;

II) A Caixa receberá o ouro e emitirá um novo título sem quebra do padrão monetário vigente, ao impedir as oscilações a Caixa eliminará a especulação;

III) Caso ocorra uma queda nas cotações, a Caixa não impedirá a adoção de medidas metalistas;

IV) O fim da oscilação cambial levará ao equilíbrio dos preços internos;

V) Facilitará a abertura de contas em ouro no Banco do Brasil;

VI) Para permitir uma lenta e gradual elevação das taxas de câmbio, acompanhadas de crescimento econômico, a Caixa terá um limite para a emissões;

VII) O ouro recebido só poderá ser utilizado para quitar os títulos da Caixa. Afinal, segundo Campista “ As emissões da Caixa de Conversão não produzem effeito inverso ao do resgate, porque taes emissões não tem a mesma natureza do papelmoeda". Este, o papel-moeda é conduzido por outras condições, em verdade:

A moeda obedece à lei do Maximo de utilização, o que quer dizer que ella procura mercados onde o seu emprego é mais reproductivo. Mas essa é a boa moeda que tem por campo de acção todo o mercado interncional e não o papel inconversível, cuja acção fora limitada ao território do paiz emissor. Na hypothese, como é a do projeto, de uma circulação mixta, constituída de um lado pelo papel de curso forçado e de outro pelas emissões conversiveis da caixa, - a superabundancia do meio circulante, evidentemente, só teria lugar ou por novas emissões de papel-moeda ou pela concorrencia das emissões ouro, que vamos fazer. $^{283}$

Segundo seu relatório em 1907, o valor das exportações brasileiras eram quase monopolizados pelo Café com 53\% e a borracha com 27\%. São Paulo acumulou 310 contos naquele ano (38\% do total), o Rio 110 contos (13\%), Amazonas 100 contos (12\%), Pará 100 contos (12\%), Bahia 70 contos $(8,5 \%)$, Pernambuco 22 contos $(2,5 \%)$ e outros estados 130 contos (14\%). Nossos principais destinos foram os Estados Unidos (36\% das compras), Alemanha(17\%), Inglaterra(14\%) e França (13\%). Entre os produtos importados destacavam-se os alimentos em geral 7,7\%, a farinha de trigo

\footnotetext{
${ }^{283}$ Relatório do Ministério dos Negócios da Fazenda de 1906. República Federativa dos Estados Unidos do Brazil. Outubro de 1907. Imprensa Oficial. Rio. Ministro Dr.David Campista. Pág. XXXV
} 
$5,35 \%$, o trigo em grãos 4,7\%, vinhos 4,98\% ( Importante dado para a futura abertura de indústrias no setor), as ferramentas $6,76 \%$. Ferros e minérios consumiam $6,73 \%$; outros $5,08 \%$ para o carvão e 13,04\% eram consumidos em manufaturados.

David Campista também defende o capital estrangeiro:

Sem duvida que - paizes novos como o nosso, sem capitaes proprios e sem iniciativa particular intensa, não podem impulsionar $o$ aproveitamento das riquezas, nem realizar as grandes obras de que carece para o seu progresso material, com os recursos normaes da renda ordinaria. Hão de fazer appêllo á economia extrangeira e contar frequentemente com os recursos extraordinários que ella lhes possa proporcionar. ${ }^{284}$

O doutor, como costumeiro entre as oligarquias, tece autoelogios:

Na historia financeira do Brasil, o anno de 1907 ficara assignalado como o primeiro em que a estabilidade cambial foi inflexivelmente mantida, chegando nos ultimos tempos á fixidez absoluta que ainda hoje perdura, apezar do momento que atravessamos, caracterizado normalmente pelo enfraquecimento do mercado monetario. ${ }^{285}$

Se tudo ia bem, se as medidas sempre foram corretas, porque a persistência da inflação e dos déficits? Mais do que isso, qual a justificativa do esforço eterno da população com as medidas recessivas?

Campista defende a Caixa de Conversão mais uma vez:

A esperança de lucro facil activa as transações e determina a frequencia dos depositos particulares de ouro. Não existisse a Caixa de Conversão e a necessidade de suprimento aos colonos e viajantes determinaria a importação de ouro feita por compra no mercado de cambio, isto é, augmentaria a procura de cambiaes justamente no tempo em que estas mais escassas se tornam, como é o tempo que decorre a terminação das colheitas e o principio das novas safras. ${ }^{286}$

\footnotetext{
${ }^{284}$ Relatório do Ministério dos Negócios da Fazenda de 1907. República Federativa dos Estados Unidos do Brazil. Outubro de 1908. Imprensa Oficial. Rio. Ministro Dr.David Campista. Pág. IX

${ }^{285}$ Ibid. Pág X

${ }^{286}$ Relatório do Ministério dos Negócios da Fazenda de 1907. República Federativa dos Estados Unidos do Brazil. Outubro de 1908. Imprensa Oficial. Rio. Ministro Dr.David Campista. Pág. XXVII
} 
Na página LVIII (Relatório de 1907), ele cita os lucros das ferrovias. As de Farquhar aparecem na lista: a São Paulo Railway com £ 604.100 e a Rio de Janeiro Tramway, L \& P. Co. com £ 322.000. Curioso notar que num país "nacionalista", que já iniciara as batalhas para impedir os negócios do empresário ianque no Brasil, as outras 17 empresas elencadas são todas estrangeiras, como a Leopoldina Railway, a Great Western, o Brasilianische Bank, a Dummont Coffee e a Amazon Steel Navigation Co.. Farquhar não estava sozinho nas concessões.

A página LVII ( Relatório de 1907) temos as exportações em valores totais:

Tabela 10 - Relatório das Exportações

\begin{tabular}{|l|l|l|ll|}
\hline & Mil Réis, papel & Equivalente em Libras $(\mathfrak{f})$ & Cambio official \\
\hline 1901 & $860.828: 694 \$ 000$ & 40.621 .993 & 11 & $17 / 64$ \\
\hline 1902 & $735.940: 125 \$ 000$ & 36.437 .456 & 11 & $55 / 64$ \\
\hline 1903 & $742.632: 278 \$ 000$ & 36.883 .175 & 11 & $61 / 64$ \\
\hline 1904 & $776.367 .418 \$ 000$ & 39.430 .130 & 12 & $1 / 8$ \\
\hline 1905 & $685.456: 606 \$ 000$ & 44.643 .113 & 15 & $25 / 32$ \\
\hline 1906 & $799.409: 205 \$ 000$ & 53.059 .480 & 16 & $1 / 32$ \\
\hline 1907 & $860.890: 882 \$ 000$ & 54.176 .898 & 15 & $5 / 64$ \\
\hline
\end{tabular}

Percebe-se que o câmbio permaneceu praticamente estável entre 1901 e 1905 e as exportações tiveram pequena queda tanto em mil réis quanto em libras. Com o Convênio de Taubaté e a Caixa de Conversão, além da desvalorização cambial razoável a partir de 1905, as exportações voltaram a crescer em mil réis e deram um salto de mais de 30\% em moeda forte entre 1901 e 1907.

A página LXII (Relatório de 1907) observamos a importância permanente do café e da borracha e a dificuldade para um investidor estrangeiro em perceber a crise da borracha se acaso lesse tais relatórios. Muitos criticaram em Farquhar sua " falta de visão" ao não perceber que a borracha estava em crise. Mas ninguém contemporâneo dele observou isso. Não se pode julgar os erros do passado, com a comodidade do tempo distante. Os dois produtos ( café e borracha) variaram entre 79,9\% do total em 1901 para $76,3 \%$.

No mesmo ano, o relatório do Ministro da Viação, Miguel Calmon du Pin e Almeida $^{287}$, defende a indústria, mostrando um viés mais Papelista e industrialista do governo Afonso Penna. Nosso Sísifo alterna os humores.

\footnotetext{
${ }^{287}$ Miguel Calmon Du Pin e Almeida ( * Salvador, 1879/ + Rio de Janeiro, 1935) foi um engenheiro e político brasileiro, correligionário de Rui Barbosa, ministro da Viação e Obras Públicas e, posteriormente, da Agricultura, Indústria e Comércio nas primeiras décadas da "República Velha". Foi também sobrinho homônimo do Marquês de Abrantes. De 15 de novembro de 1906 a 18 de julho de 1909 foi Ministro e Secretário de Estado dos Negócios da Indústria, Viação e Obras Públicas, do Governo Afonso
} 
O capitalismo, como tudo mais, não é mal nenhum, para quem dele, em absoluto, carece. Já se disse que é uma consequencia forçada da expansão industrial, oriunda da proteção aduaneira. Pois bem: ate sob esse aspecto, o protecionismo nos será favoravel. Affirma-se, outrossim, que a creação de industrias faz grande mal á lavoura, com lhe desfalcar os braços. Dado que isto aconteça, valera menos o estimulo, para adquirir a feição moderna a industrialização que lhe hoje impende, vindo da pratica e exemplo daquelas? ${ }^{288}$

Defende Calmon que as vias férreas concedidas fossem acompanhadas do processo de colonização, lição esta seguida por Farquhar na Ferrovia São Paulo-Rio Grande. (Relatório 1908. pág V) e depois explica a necessidade da Madeira-Mamoré:

A construção dessa obra foi, desde o tempo do Imperio, considerada como o plano mais adequado de comunicação do norte da Republica da Bolivia e do Estado do Mato Grosso com o oceano Atlantico, e assim também o entendeu o governo da Republica, quando, pelo Tratado de Petropolis, se obrigou a effectual-a, tendo em vista, além de outras vantagens favorecer uma vasta e riquíssima região... ${ }^{289}$

Mas em 1908, a crise se anuncia. Campista cita à página V, a "forte baixa dos preços da borracha na Amazonia", medida esta que teria sido contida pelos aportes concedidos pelo Banco do Brasil. No café, a ação do banco foi essencial, afinal a queda dos preços foi acentuada, devido ao excesso de 'stock'.

No relatório de 1909, já com o retorno do metalista Bulhões, este ministro apresenta dados sobre a variação da exportação.

Entre 1902 a 1907 o saldo comercial brasileiro cresceu constantemente em libras esterlinas. De 1902 para 1903, subiu 2,3\%. Depois 6,8\% (1903-1904), 13,97\% (19041905); 15,83\% (1905-1906); 9,74\% (1906-1907) e -16,39\% ( de 1907 para 1908) (Relatório 1909. pág. IV). Confirma-se a crise do último ano. A recessão que atingia os

Pena e depois de Nilo Peçanha. Retornou ao governo, agora sob a presidência de Artur Bernardes, como Ministro da Agricultura, Indústria e Comércio, de 16 de novembro de 1922 a 15 de novembro de 1926. (Fonte: Galeria dos Ministros da Fazenda. Disponível em: < http://fazenda.gov.br/acesso-a-informacao/institucional/galeria-dos-ministros/pasta-republica/republica.>. Acessado em $7 / 11 / 2016)$

${ }^{288}$ Relatório do Ministério da Industria, Obras e Viação Publicas de 1907. República Federativa dos Estados Unidos do Brazil. Outubro de 1908. Imprensa Oficial. Rio. Ministro Miguel Calmon du Pin e Almeida. Págs. V e VI

${ }^{289}$ Relatório do Ministério da Industria, Obras e Viação Publicas de 1907. República Federativa dos Estados Unidos do Brazil. Outubro de 1908. Imprensa Oficial. Rio. Ministro Miguel Calmon du Pin e Almeida. Págs. 362 
Estados Unidos e Europa deixavam marcas na economia brasileira. Uma economia dependente e interligada.

Informa que a amortização da dívida externa que havia sido suspensa por 13 anos ( e voltaria em 1911) propostas pelo funding loan, foi adiantada para 1910. Denotava-se uma piora da situação econômica do país. E defende que:

...aquelle accôrdo [ funding loan], dictado pelas circumstancias excepcionaes do paiz em 1898 e executado rigorosamente de modo a nos fazer honra, permittio, com a reconstrução das finanças nacionaes, a realização de obras publicas de real valor e a reconstituição de nosso aparelho militar. As condições de nossas finanças, porem, autorizava a antecipação da retomada daquelle serviço e o resultado do vosso acto não podia deixar de reflectir-se, como de facto se reflectio, no credito publico, para mais avigoral-o... ${ }^{290}$

Bulhões nos apresenta dados estatísticos sobre os 13 anos de funding loan. Esclarece sobre o papel-moeda em circulação e seu resgate. Uma análise do Metalismo do período Murtinho a Bulhões:

Tabela 11 - O papel-moeda em circulação ${ }^{291}$

\begin{tabular}{|l|l|l|c|}
\hline \multicolumn{4}{|c|}{ O Papel Moeda em Circulação ( columna A - total e columna B - retirado) } \\
\hline $31 / 12 / 1898$ & $785.364: 614 \$ 500$ & 1898 & $2.422: 856 \$ 500$ \\
\hline $31 / 12 / 1899$ & $733.727: 153 \$ 000$ & 1899 & $52.214: 605 \$ 000$ \\
\hline $31 / 12 / 1900$ & $699.631: 719 \$ 000$ & 1900 & $34.095: 434 \$ 000$ \\
\hline $31 / 12 / 1901$ & $680.451: 058 \$ 000$ & 1901 & $19.180: 661 \$ 000$ \\
\hline $31 / 12 / 1902$ & $675.536: 784 \$ 000$ & 1902 & $4.914: 274 \$ 000$ \\
\hline $31 / 12 / 1903$ & $674.978: 942 \$ 000$ & 1903 & $557: 842 \$ 000$ \\
\hline $31 / 12 / 1904$ & $673.739: 908 \$ 000$ & 1904 & $1.239: 034 \$ 000$ \\
\hline $31 / 12 / 1905$ & $669.492: 608 \$ 700$ & 1905 & $4.247: 300 \$ 000$ \\
\hline $31 / 12 / 1906$ & $664.792: 960 \$ 500$ & 1906 & $4.699: 648 \$ 000$ \\
\hline $31 / 12 / 1907$ & $643.531: 727 \$ 000$ & 1907 & $21.261: 233 \$ 000$ \\
\hline $31 / 12 / 1908$ & $634.682: 852 \$ 000$ & 1908 & $8.848: 875 \$ 000$ \\
\hline $31 / 12 / 1909$ & $628.452: 732 \$ 000$ & 1909 & $6.230: 620 \$ 000$ \\
\hline $30 / 09 / 1910$ & $623.078: 310 \$ 500$ & 1910 & $5.374: 421 \$ 000$ \\
\hline
\end{tabular}

Percebe-se claramente que as políticas de retirada do papel-moeda ocorreram no período todo. Entre 1898 e 1910 foram retirados do mercado mais de $20 \%$ do meio circulante e mesmo assim, como visto, os ministros e políticos da república Velha se

\footnotetext{
${ }^{290}$ Relatório do Ministério dos Negócios da Fazenda de 1909. República Federativa dos Estados Unidos do Brazil. Outubro de 1910. Imprensa Oficial. Rio. Ministro Leopoldo de Bulhões. Pág. VIII

${ }^{291}$ Relatório do Ministério dos Negócios da Fazenda de 1909. República Federativa dos Estados Unidos do Brazil. Outubro de 1910. Imprensa Oficial. Rio. Ministro Leopoldo de Bulhões. Pág. XIII
} 
sucediam em proferir que o país não parava de emitir e que eram necessários esforços suplementares. Esforços que nunca vinham do café ou dos cafeicultores.

A página XXVII, Bulhões defende a alta do moeda, pois somos um país de importação de gêneros, segundo ele. O câmbio elevado favoreceria o produtor nacional:

Quanto á lavoura são infundados os receios de prejuizos. Nem só, para se ajustarem ás condições monetarias do paiz, muitos dos elementos formadores dos preços se estipulam em relação com o valor-ouro da moeda (fretes variaveis com o cambio, taxa de 5 francos sobre o café exportado, salarios fixados em metal, divida contrahidas no estrangeiro, mercadorias de consumo adquiridas pela importação), e portanto só se alterarão beneficamente com a alta cambial, como ainda por effeito desta as parcellas pagas em papel se reestabelecerão aos poucos, de acordo com o nivel de cambio, movimento lento, mas incontestavel, que faz evoluir para cima muitas despezas firmadas em papel no periodo da depreciação progressiva do meio circulante e as fará variar em sentido inverso na quadra ascensional. ${ }^{292}$

Comenta sobre as políticas econômicas adotadas até então, defendendo os ideais Metalistas:

Nos paizes de papel-moeda, porem, o cambio è cousa diversa: indica o valor actual da cedula financeira, patenteia uma estimativa do ouro supposto, que cada cedula contem no seu nominal inscripto. Nesses paizes, a moeda de ouro deixa de ser moeda, para se tornar mercadoria só, de preço variavel; de tal sorte que, nas operações cambiaes, a medida nacional dos valores, ou a cedula circulante, é metro absurdo, que se encurta ou se alonga, e por isso mesmo não é metro. Para os productores de generos exportaveis, pagos em ouro, a conversão do metal em papel enche-lhes a bolsa com este, depreciado pelo cambio baixo; e, porque com este são pagos os salarios e solvidas as dividas ordinarias, o agio do ouro se lhes afigura appetecivel, ou, em outros termos, a desvalorização da moeda circulante se lhes afigura cobiçavel. Esquecem, porem, que o agio é quantidade negativa, que a

${ }^{292}$ Ibid. Pág. XXVII 
nenhum patrimonio se incorpora, que não traz riqueza, mas unicamente um espectro de riqueza, entontecedor e escarninho... ${ }^{293}$

Por último, Bulhões descreve as vantagens que o Brasil teve por meio da adoção do funding loan:

....a admiravel viagem pela estrada dos sacrifícios, propuzemo-nos, de um lado a demonstrar ao mundo a nossa probidade, e ao povo, de outro lado, o nosso patriotismo (...) Augmentamos os impostos e creamos tributações novas; impuzemos à Nação uma especie de dieta, com differimento da attenção que mereciam seus desejos de progresso e de goso; cortamos fundamente nas despezas; avolumamos notavelmente a renda e fomos, com impavidez, cumprindo todas as clausulas do doloroso contracto (...) O esforço foi maximo e, por isso, a emenda foi gloriosa. Temos enveredado no caminho da reconstrucção mais rápida... ${ }^{294}$

\subsection{Francisco Salles ${ }^{295}$ ( Ministro da Fazenda de 1910 e 1911)}

Um incêndio destruiu o relatório de 1910 e parte do relatório de 1911. Dessa forma, Francisco Salles apresenta o relatório apenas em fins de 1912. Começa anunciando que o país estava pronto para ficar equilibrado no que tange a receita e despesa, defendendo que o país deveria chegar finalmente ao regime de moeda conversível.

O equilibrio orçamentario continua a ser uma aspiração, que só terá effectividade quando os orçamentos deixarem de ser elaborados com déficits e na sua execução for observado o alto pensamento de não elevar os gastos além dos limites da renda ordinaria. (...) os dados deste relatorio confirmam, desde 1908 que os orçamentos se encerram com deficits e em progressão crescente... ${ }^{296}$

\footnotetext{
${ }^{293}$ Relatório do Ministério dos Negócios da Fazenda de 1909. República Federativa dos Estados Unidos do Brazil. Outubro de 1910. Imprensa Oficial. Rio. Ministro Leopoldo de Bulhões. Pág XXX

${ }^{295}$ Francisco Antônio de Salles (* Lavras 1863/ + Rio 1933). Bacharelado em Direito pela Faculdade de São Paulo. Senador; Prefeito de Belo Horizonte. Em 1902 assumiu a Presidência do Estado de Minas Gerais permanecendo até 1906. No período de sua administração no Ministério da Fazenda ( 1910-1913) reorganizaram-se a Caixa de Conversão e a Delegacia do Tesouro Nacional em Londres; regulou-se a emissão e a circulação do cheque. Realizaram-se operações crédito no exterior e autorizou-se a emissão de papel-moeda e de apólices para resgatar compromissos do Tesouro Nacional. ( Fonte: Galeria dos Ministros da Fazenda. Disponível em: 〈http://fazenda.gov.br/acesso-a-informacao/institucional/galeria-dos-ministros/pasta-republica/republica. $>$ Acessado em 7/11/2016)

${ }^{296}$ Relatório do Ministério dos Negócios da Fazenda de 1910 e 1911. República Federativa dos Estados Unidos do Brazil. Outubro de 1912. Imprensa Oficial. Rio. Ministro Francisco Antonio de Salles. Pág. III
} 
Cita o aumento dos impostos de consumo como uma das provas da melhoria geral da economia (Relatório 1912. pág VII). Pois, segundo ele, para consumir alguém produziu. Segundo Salles, o estado não pode substituir a iniciativa privada, mas pode socorrê-la "...um motor do progresso, para acudir com seu socorro sereno, meditado e consistente e resistente á medrosa iniciativa privada.” (pág VIII)

Critica a dependência brasileira para com o café e a borracha:

A producção daquelles dois gêneros apenas é um perigo permanente, a instabilidade economica, é a ameaça de abalos financeiros, dada uma crise de baixa dos preços ou de falha na producção, que, diminuindo a entrada do ouro estrangeiro, nos obrigue, para fazer face ao custo da importação, lançar mão das nossas reservas metallicas, deprimindo a taxa de cambio. Temos, além disso, que pensar na situação da borracha, ameaçada pela concurrencia indiana. É certo que, embora já grande a producção da gomma elastica de Sumatra, Ceylão e alhures, a nossa ainda tem a preponderância da quantidade e qualidade. ${ }^{297}$

Anuncia um plano de proteção da borracha, que segundo cálculos daquele governo sofreria um baque entre 1915 e 1917 ( o que se confirmou). Defende uma diversidade maior na economia brasileira:

...em vez de dois productos de grande exportação, tenhamos muitos outros distribuídos geographicamente, na sua producção, de conformidade com as indicações praticas, por todas as zonas agricolas do paiz. Supprimidas as distancias pelo vapor e electricidade, o mundo commercial transfigurou-se e está fora delle quem se isola. (...) teremos de procurar mercados para nossos outros productos. ${ }^{298}$

Salles poderia ser considerado um ministro papelista. Sísifo e seu eterno retorno.

\subsection{Rivadávia da Cunha Corrêa ${ }^{299}$ ( ministro da Fazenda de 1913-1914)}

\footnotetext{
${ }^{297}$ Ibid. IX

${ }^{298}$ Ibid. Pág. XVII

${ }^{299}$ Rivadávia da Cunha Corrêa (* Santana do Livramento,1866/ + Petrópolis, 1920) Bacharelado em Direito pela Faculdade de São Paulo (1887). Em 1910 ocupou o cargo de Ministro da Justiça e Interior (1910-1913). Nomeado em 1913 em caráter interino para a pasta da Fazenda passou a efetivo quando se exonerou do cargo de Ministro da Justiça e Interior.Em face das crescentes dificuldades do comércio interno e externo utilizaram-se emissão de papel-moeda e de notas do Tesouro Nacional para pagamento de despesas e empréstimos a bônus bem como contrato de novo empréstimo com os banqueiros N. M. Rothschild and Sons de Londres. Foi Prefeito do Distrito Federal e Senador. (Fonte: Galeria dos Ministros da Fazenda.Disponível em: < http://fazenda.gov.br/acesso-ainformacao/institucional/galeria-dos-ministros/pasta-republica/republica>. Acessado em 7/11/2016)
} 
Anuncia os tempos difíceis com o fim da liquidez mundial pré Grande Guerra:

Os bancos europeus, comprehendendo a necessidade de augmentar os seus encaixes metallicos, restringiram todas as operações e ordenaram ás filiaes e aos bancos com que mantinham relações na América do Sul que liquidassem negocios e remetessem fundos. Era uma completa reviravolta na vida financeira dos mercados desta parte do continente americano:ás facilidades de pouco antes succedia um repentino regimen de aperto, e os bancos que anteriormente buscavam e, por assim dizer, caçavam os clientes, forçando-os a abrir creditos em suas caixas, agora não só lhes negavam esse credito necessário ao prosseguimento dos negocios. ${ }^{300}$

Defende um barateamento da produção da borracha, numa região em que o trabalho era quase escravo. Aprofunda o mito do 'eldorado' ( ou 'helldorado', como dizia Farquhar depois de sua aventura na Madeira-Mamoré). Defende uma diversificação amazônica para a redução da dependência em relação aos seringais:

No dia em que a Amazonia, aproveitando a extraordinária uberdade do seu solo, conseguir resolver dentro das suas fronteiras o problema de sua propria alimentação, terá dado solução ao caso da borracha (...) os dous ricos Estados do norte, parece, já começam a comprehender, iniciando as lavouras de cereas e a creação de gados, de sorte a terem os alimentos de que carecem (..) permanecerem obrigados á importação... ${ }^{301}$

Critica o chamado "fetichismo do café e da borracha". Um país que procura vender a preços altíssimos os dois gêneros principais, sem encontrar mercados suficientes e tendo ainda de importar a preços elevados produtos de primeira necessidade, segundo ele, comete erros econômicos primários. Faltavam-nos artigos como o trigo, milho, a batata, a cebola, tudo isso num país agrário. Dessa forma, nos tornamos um país de déficits sucessivos. Mesmo durante o $1^{\circ}$ funding loan foram deficitários os anos de 1904, 1908 e 1909 e depois de 1910 a 1912. ( Relatório 1913. pág. X). Segundo Correa:

\footnotetext{
${ }^{300}$ Relatório do Ministério dos Negócios da Fazenda de 1913. República Federativa dos Estados Unidos do Brazil. Outubro de 1914. Imprensa Oficial. Rio. Ministro Rivadávia Corrêa. Pág. I

${ }^{301}$ Ibid. Pág. VIII
} 
A receita veio sempre crescente até 1913, mas em contraste, a despeza augmentou tambem de maneira extraordinaria, já por effeito das despezas novas votadas annualmente, já como consequência de contractos e concessões de grandes obras com que os governos da Republica a partir de 1903 oneraram o Thezouro, já por effeito das leis inçadas de excessivos favores aos servidores do paiz, já finalmente pelos grandes dispêndios com a reorganisação da Marinha e do Exercito. ${ }^{302}$

Corrêa faz um apanhado geral do período de Murtinho até o dele. E reconhece que vivemos num estado de ' anarquia econômica", pois passados 16 anos do remédio amargo, o país encontra-se na mesma situação do passado. ( Relatório 1913. pág. XVI). Um novo funding loan seria negociado em seu ministério:

...vieram accumular-se, não só as consequências da política de melhoramentos materiaes que tomou decisivo impulso depois de 1903, como a necessidade de dar satisfação ao serviço da divida externa que se apresentara accrescida da amortização dos emprestimos contrahidos antes do funding loan e que delle fizeram parte; da amortização dos titulos emittidos em cumprimento do mesmo funding loan e dos juros e amortizações dos emprestimos de 1903, 1908 e 19101, na somma de 22,5 milhões de libras, e mais dos emprestimos, em 1908, 1909 e 1910 na soma de 35,1 milhões de libras. ${ }^{303}$

Conclui-se então que os 16 anos de políticas predominantemente Metalistas (menos os anos David Campista de 1906 a 1909), com a adoção de medidas recessivas; e inflacionistas dos gêneros importados ( então a maioria do nosso consumo); desestimulantes ao capital industrial nacional - foram infrutíferas. Protegeram um setor específico, a grande lavoura do café e puniram a maioria da classe trabalhadora e dos setores médios do país. Os gastos públicos só cresceram, demonstrando o péssimo gerenciamento da coisa pública ( lembrando que na República Velha quase não havia despesas com Saúde, Educação e Previdência). Um estado perdulário, para poucos e que vivia de endividar-se para pagar velhas dívidas.

\footnotetext{
${ }^{302}$ Relatório do Ministério dos Negócios da Fazenda de 1913. República Federativa dos Estados Unidos do Brazil. Outubro de 1914. Imprensa Oficial. Rio. Ministro Rivadávia Corrêa. Pág. XVI

${ }^{303}$ Ibid. Pág. XVIII
} 
Corrêa acusa que boa parte dos empréstimos realizados pelo II Império nada mais eram do que formas de se quitar dívidas antigas e seus serviços. Na República:

... esse facto se foi accentuando cada vez mais, de sorte que, os ultimos emprestimos externos no regimens republicano foram quase completamente absorvidos no pagamento de juros da divida no exterior..."304

E alega que a única diferença entre essa situação e a sua negociação para o $2^{\circ}$ funding loan (1914) realizada por ele, era que:

...neste emprestimo para pagamentos de juros da divida externa e garantia de estradas de ferro durante tres annos, foi feito pelos mesmos credores. A quem era devido o pagamento desses juros, ao passo que em outras épocas os novos empréstimos foram tomados por pessoas diversas. ${ }^{305}$

\subsection{Pandiá Callógeras ${ }^{306}$ ( ministro da Fazenda de 1915-1917)}

Pandiá inicia com a velha ladainha da emissão, ou seja, mais um Metalista. Porém, como vimos na tabela 10 de Bulhões, não houve a tal emissão. "Emittir, como em nosso paiz se tem usado, não é um remédio; vale por um expediente. “ ( Relatório de 1915. Pág. VI). E o que deve então fazer o país, segundo Callógeras:

O dever do momento, portanto, é merecermos confiança do paiz e do extrangeiro. Cumpre ter em vista que egual esforço de nossos conterrâneos, foi a collaboração alienígena, pelos capitaes e pelos chefes de industria que á sorte do Brasil ligaram a sua. Delles ainda virá o auxilio, quando, em circunstancias favoraveis, tivermos de recorrer á economia mundial. E os bilhões de francos, as centenas de milhões de

\footnotetext{
${ }^{304}$ Relatório do Ministério dos Negócios da Fazenda de 1913. República Federativa dos Estados Unidos do Brazil. Outubro de 1914. Imprensa Oficial. Rio. Ministro Rivadávia Corrêa. Pág. XXX

${ }^{305}$ Ibid. Pág. XXX

306 João Pandiá Callógeras ( *Rio, 1870/ + Petrópolis, 1934) Graduado em Engenharia pela Faculdade de Ouro Preto. Deputado. Nomeado Ministro da Agricultura ocupou interinamente a pasta da Fazenda passando logo depois a titular do cargo. Em sua gestão reduziu-se a arrecadação aduaneira a um terço e paralisou-se o comércio pela situação de guerra na Europa. Promoveu uma campanha de moralização administrativa exigiu escrúpulos nos gastos compressão de despesas. Suprimiram-se cargos públicos. Consolidou toda a legislação relativa a pessoal. Em sua administração foi criado o imposto sobre os juros de créditos ou empréstimos alterado o regime de faturas consulares e aprovado o regulamento para a venda de imóveis e distribuição de prêmios mediante sorteio. (Fonte: Galeria dos Ministros da Fazenda. Disponível em:<http://fazenda.gov.br/acesso-ainformacao/institucional/galeria-dos-ministros/pasta-republica/republica>. Acessado em 7/11/2016)
} 
libras esterlinas investidos no apparelhamento industrial e commercial do Brasil... $^{307}$

As dificuldades do Brasil em 1915 seriam: a Grande Guerra que elevou fretes e seguros de viagem; os vapores que foram desviados para fins bélicos ( mesmo assim o "nacionalista" e anti-Farquhar, Callógeras, se vangloria do acordo com o Lloyd brasileiro para novas linhas e fretamento de cargueiros); tudo para escoar o café ( e só o café, ele afirma); analisa ainda que a abertura do Canal do Panamá traria problemas com o Chile. (Relatório de 1915. Pág. XVII). Mais uma vez um ministério se preocupa com a borracha e sugere " baratear o custo do seringueiro" ( provavelmente adotando a escravidão) e favorecer os transportes públicos da região.

Se de um lado a crise incomoda Callógeras, do outro a situação econômicafinanceira é a seguinte:

...o Thesouro deante de compromissos inadiáveis a solver, com receitas decrescentes, na impossiblidade practica de contrahir emprestimos no exterior e, egualmente, no interior, abalada completamente a confiança publica. Um unico caminho restava, exgottadas todas as tentativas possíveis em rumos outros: apellar para a emissão. Ainda ahi variavam as formulas quer quantitativa, quer qualitativamente. Uns preconizavam a impressão pura e simples de cedulas em importância que attingia até dous milhões de copntos de réis. Outros suggeriam letras do Thesouro. Nenhum desses alvitres podia ser seguido. Era preciso poder assegurar ás novas massas de papel, lançadas na circulação, resgate proporcionado ás exigências das permutas. $^{308}$

A página XXX, Callógeras demonstra confiança de que o pior da crise passou após o $2^{\circ}$ funding loan. Segundo ele, dos nossos nove principais produtos de exportação (responsáveis por mais de $90 \%$ das exportações brasileiras na época), entre janeiro e setembro de 1915, cresceram quantitativamente: o açúcar, a borracha, o cacau, o café, o mate e as peles. Decaíram o algodão e o fumo. O couro manteve-se estável.

\footnotetext{
${ }^{307}$ Relatório do Ministério dos Negócios da Fazenda de 1915. República Federativa dos Estados Unidos do Brazil. Outubro de 1916. Imprensa Oficial. Rio. Ministro João Pandiá Callógeras. Pág. XVI

${ }^{308}$ Relatório do Ministério dos Negócios da Fazenda de 1915. República Federativa dos Estados Unidos do Brazil. Outubro de 1916. Imprensa Oficial. Rio. Ministro João Pandiá Callógeras. Pág. XVII
} 
Relatava que os impostos sobre circulação haviam aumentado, o imposto sobre a renda também, os créditos sobre a exportação subiram da mesma forma ( Relatório de 1915. pág. XXVIII).

Na página XXXVII fala das consequências da Guerra: reduzira a produção de bens de consumo, encarecera os produtos, aumentaram os fretes e os seguros dos mesmos, criaram-se novos protecionismos e as remessas da Alemanha e da ÁustriaHungria estavam suspensas ( eram 19\% do total das importações), não havendo substituição por similares. Com a mobilização dos meios marítimos, mesmo os países aliados do Brasil reduziram os negócios ( Inglaterra, Itália e França). A renda aduaneira caiu de 348 mil contos em 1912 para 182 mil em 1914 e menos ainda em 1915.

Callogéras ataca frontalmente a política de concessões e as ferrovias, tão importantes para o Império de Farquhar. Ferrovia é patrimônio nacional.

...nada justifica que a receita federal, isto é, o produto dos impostos cobrados de Norte a Sul do Brasil, que deveram destinar-se a serviços federaes, seja desviada para preencher as insufficiencias de rendas de empreendimentos, interessando apenas trechos limitados do paiz, quando, por uma organização tarifaria mais estudada; essas mesmas zonas sustentariam o trafego correspondente sem recorrerem ao auxilio do orçamento geral. (...) se radica em meu espírito que as vias férreas devem ser planejadas pelo Estado e pertencer-lhe, sua exploração deve ser arrendada. E quanto aos transportes marítimos ou fluviais, delles se deve afastar a acção financeira da União. (...) as observações visam normalizar a vida do Thesouro, restabelecendo o equilíbrio orçamentário... ${ }^{309}$

Callógeras ressalta as imensas possibilidades econômicas advindas coma a guerra:

...como vender nossas fructas para o extrangeiro, onde nem siquer propaganda se faz precisa, pois já ali são conhecidas e apreciadas e a necessidade delas se revela nos pedidos transmittidos para aqui? Cifra-se então a questão: em organizar a compra, a conservação e o encaixotamento aqui; transportar em camaras frias; ter nos portos de destino instalações análogas; interessar no commercio os

\footnotetext{
${ }^{309}$ Relatório do Ministério dos Negócios da Fazenda de 1915. República Federativa dos Estados Unidos do Brazil. Outubro de 1916. Imprensa Oficial. Rio. Ministro João Pandiá Callógeras. Pág. XXXI
} 
revendedores extrangeiros, afim de estabelecer o incremento do negocio. $\mathrm{O}$ desenvolvimento da industria frigorifica, embora apenas no inicio, facilita a solução do primeiro ponto. Da guerra actual ficará como lição aproveitada a necessidade de aumentar a frota mercante com instalações refrigeradas(...)As madeiras estão no mesmo caso e isso em prazo de breve realização, pois si desde já precisas para fins de guerra, cessado o conflito mais necessarias se tornarão para a reconsctrução (...) perdurara esse commercio pois as operações bellicas destruíram largas reservas florestaes na Europa. ${ }^{310}$

Um último comentário de Callógeras relaciona-se a questão fiscal:

Uma grande reforma impõe-se aqui: nos methodos e no pessoal. E essa deveria abranger desde o Thesouro, onde o grupamento de serviços deve ser outro para melhor atender a receitas que já vão caminhando para a porcentagem de $25 \%$ do orçamento total (...) Não será exagero afirmar que a melhoria assim obtida na periferia do aparelho fiscal poderá aumentar de modo notável a arrecadação effectuada. $^{311}$

Depois ele critica os hábitos culturais brasileiros:

Um dos grandes óbices, porem, reside na insuficiente educação tributaria dos contribuintes. Sem intenção dolosa, muitas vezes, por mera desatenção dos principios legaes, e na falta de fiscais que os orientam devidamente, acontecem frequentemente de serem autoados e de terem de sofrer penas, quando um pouco de cuidado delas os houvera livrado. ${ }^{312}$

Curioso notar que entre as principais dragas que sangravam os rios amazônicos em direção ao Porto do Pará em 1913, construído por Percival Farquhar,estavam duas que carregavam o nome de David Campista e Miguel Calmon Du Pin e Almeida. Os ministros que defenderam a presença do empresário americano que é o primeiro capítulo desta tese.

\footnotetext{
${ }^{310}$ Ibid. Pág. 36, volume 2

${ }^{311}$ Relatório do Ministério dos Negócios da Fazenda de 1915. República Federativa dos Estados Unidos do Brazil. Outubro de 1916. Imprensa Oficial. Rio. Ministro João Pandiá Callógeras. Pág. 37. Volume 2

${ }^{312}$ Ibid.Página 37. Volume 2
} 
Encerra-se aqui o último capítulo. Os anos entre 1898 e 1915 assistiram a uma sucessão de medidas econômicas que buscavam restringir o papel-moeda. Houve dois breves hiatos: o período de David Campista e o de Francisco Salles. O mesmo se deu com a pretensa luta entre Agralistas e Industrialistas. O que se via, em verdade, era uma sucessão de medidas que ora beneficiavam mais um setor, ora outro. Em comum: a valorização do café, as políticas internas recessivas, os empréstimos externos utilizados quase sempre para pagar dívidas anteriores, os déficits orçamentários e a total exclusão das camadas médias e pobres da sociedade brasileira, seja do discurso ou mesmo das políticas econômicas. Talvez os oligarcas acreditassem na fala de Lima Barreto de que no Brasil não havia povo, mas sim público. Coube ao médico homeopata Joaquim Murtinho tecer o diagnóstico de nossas contas públicas e preconizar o remédio amargo, protegendo-se sempre os homens de boa saúde. Farquhar, apesar de boa saúde, possuía um defeito de nascença: era norte-americano. 


\section{CONCLUSÃO}

Após o longo trajeto desta tese procurarei encerrar de forma sucinta. Pretendeuse aqui realizar um estudo de história econômica, no qual a economia e a sociedade possuem pesos nem sempre díspares e em sua maioria complementares. Procurou-se amenizar as análises teóricas com aspectos da vida social, cultural e política do período estudado, pois nas palavras de Piketty:

Sejamos francos: a economia jamais abandonou sua paixão infantil pela matemática e pelas especulações puramente teóricas, quase sempre muito ideológicas, deixando de lado a pesquisa histórica e a aproximação com as outras ciências sociais. Com frequência, os economistas estão preocupados, acima de tudo, com pequenos problemas matemáticos que só interessam a eles, o que lhes permite assumir ares de cientificidade e evitar ter de responder às perguntas mais complicadas feitas pelo mundo que os cerca. ${ }^{313}$

O presente doutorado delimitou seu estudo com início em 1898, ano da introdução das medidas econômico-financeiras de Joaquim Murtinho e a renegociação da dívida externa, denominada de Funding Loan ( o primeiro de 1898). Posteriormente, com a repetição de erros na administração do país, bem como na constante política de salvação do café, mais dois empréstimos semelhantes foram necessários, em 1914 e 1931.

Nossos economistas e governantes adotaram medidas de contenção de papelmoeda, com caráter recessivo, a denominada ideologia Metalista. Em alguns breves momentos assistimos a reversão desses ideais com pensadores que defendiam a relação direta entre o meio circulante e o desenvolvimento industrial do país. Foram conhecidos como Papelistas.

Tratou-se aqui de uma análise do pensamento econômico brasileiro, suas principais vertentes, as influências externas dos economistas clássicos e neoclássicos. A luta entre metalistas e papelistas, nacionalistas e investidores estrangeiros, agralistas e industrialistas, na República Velha e os planos econômicos com destaque para o

\footnotetext{
${ }^{313}$ PIKETTY, Thomas. O capital no século XXI, Pág. 42
} 
Funding Loan de Campos Salles e Joaquim Murtinho. Boa parte delas alicerçada nos relatórios ministeriais da Fazenda entre 1898 e 1915.

Percebeu-se claramente uma sociedade em profundas transformações: um país agrário, quase monocultor, com trabalhadores negros recém-libertos e uma classe dominante totalmente desconexa de sua população mais pobre que assistia a formação de um mundo urbano, com imigrantes e homens livres pobres (quase sempre negros), uma economia em franca industrialização e políticas que cada vez mais precisavam voltar seus olhos para as classes desfavorecidas.

Em meio a esse turbilhão de mudanças sociais, econômicas e políticas. Com as elites agrárias e os novos barões da indústria pensando a realidade do país, desconsiderando-se a existência do povo, dos conflitos sociais e das desigualdades econômicas, encontramos um empresário norte-americano que buscou edificar seu império burguês num Brasil repleto de possibilidades: Percival Farquhar.

A construção de seus negócios no Brasil; a resistência do empresariado brasileiro, o qual extirpou Farquhar dos próprios negócios em defesa da nação, quando, em verdade, o ponto central dessas elites oligárquicas era repassar as atividades econômicas para os empresários brasileiros que utilizavam a mesma lógica de organização econômica da qual se valia o investidor quacre; as relações nem sempre honestas com nossos políticos são importantes para o entendimento da denominada República Velha.

O estudo desta tese estende-se até 1931. Nesse ano tivemos o terceiro e último funding loan, o esfriamento total do projeto Itabira Iron de Farquhar e, principalmente, a ascensão de uma nova classe política e empresarial no governo do país. As lutas não seriam mais as mesmas. Farquhar permanece no Brasil até 1952, entretanto como um pálido retrato do que foi. Uma imagem sendo apagada lentamente da memória, como a República Velha.

A História, segundo Rank, deve apresentar os fatos exatamente como eles foram. Porém, se mesmo para os que as vivenciaram, estes fatos nunca são interpretados consensualmente, sendo as narrativas dos antepassados repletas de incongruências e distinções, exigir do historiador uma reprodução fiel e objetiva do passado é uma obra de ficção. O historiador é uma testemunha distanciada pelo tempo e, dessa forma:

Por mais que lutemos arduamente para evitar os preconceitos associados a cor, credo, classe ou sexo, não podemos evitar olhar o passado de um ponto de vista particular. O relativismo cultural 
obviamente se aplica, tanto a própria escrita da história, quanto a seus chamados objetos. Nossas mentes não relfetem diretamente a realidade. Só percebemos o mundo através de uma estrutura de convenções, esquemas e estereótipos, um entrelaçamento que varia de uma cultura para outra. Nessa situação, nossa percepção dos conflitos é certamente mais realçada por uma apresentação de pontos de vista opostos do que por uma tentativa de articular o consenso. ${ }^{314}$

Esta tese tratou das permanências históricas das elites agrárias e da classe dominante brasileira entre 1898 a 1931 . Uma classe liberal sem praticar o liberalismo. Dona de um projeto arcaizante com traços de modernidade, ou como diria Sérgio Buarque de Holanda “ um povo desenraizado em sua própria terra”. Tudo isso em meio a uma convulsão social e econômica pela qual passava o país.

A História é aquilo que os homens de sua época nunca vivenciaram.

${ }^{314}$ BURKE, Peter. A escrita da história. Pág. 17 


\section{FONTES PRIMÁRIAS}

1. Relatório do Ministério dos Negócios da Fazenda de 1898. República Federativa dos Estados Unidos do Brazil. Outubro de 1899. Imprensa Oficial. Rio. Ministro Joaquim Murtinho.

2. Relatório do Ministério dos Negócios da Fazenda de 1899. República Federativa dos Estados Unidos do Brazil. Outubro de 1900. Imprensa Oficial. Rio. Ministro Joaquim Murtinho.

3. Relatório do Ministério dos Negócios da Fazenda de 1900. República Federativa dos Estados Unidos do Brazil. Outubro de 1901. Imprensa Oficial. Rio. Ministro Joaquim Murtinho.

4. Relatório do Ministério dos Negócios da Fazenda de 1901. República Federativa dos Estados Unidos do Brazil. Outubro de 1902. Imprensa Oficial. Rio. Ministro Joaquim Murtinho.

4. Relatório do Ministério dos Negócios da Fazenda de 1902. República Federativa dos Estados Unidos do Brazil. Outubro de 1903. Imprensa Oficial. Rio. Ministro Leopoldo de Bulhões.

5. Relatório do Ministério dos Negócios da Fazenda de 1903. República Federativa dos Estados Unidos do Brazil. Outubro de 1904. Imprensa Oficial. Rio. Ministro Leopoldo de Bulhões.

6. Relatório do Ministério dos Negócios da Fazenda de 1904. República Federativa dos Estados Unidos do Brazil. Outubro de 1905. Imprensa Oficial. Rio. Ministro Leopoldo de Bulhões.

7. Relatório do Ministério dos Negócios da Fazenda de 1905. República Federativa dos Estados Unidos do Brazil. Outubro de 1906. Imprensa Oficial. Rio. Ministro Leopoldo de Bulhões. 
8. Relatório do Ministério dos Negócios da Fazenda de 1906. República Federativa dos Estados Unidos do Brazil. Outubro de 1907. Imprensa Oficial. Rio. Ministro Dr.David Campista.

9. Relatório do Ministério dos Negócios da Fazenda de 1907. República Federativa dos Estados Unidos do Brazil. Outubro de 1908. Imprensa Oficial. Rio. Ministro Dr.David Campista.

10. Relatório do Ministério da Industria, Obras e Viação Publicas de 1907. República Federativa dos Estados Unidos do Brazil. Outubro de 1908. Imprensa Oficial. Rio. Ministro Miguel Calmon du Pin e Almeida.

11. Relatório do Ministério dos Negócios da Fazenda de 1908. República Federativa dos Estados Unidos do Brazil. Outubro de 1909. Imprensa Oficial. Rio. Ministro Dr.David Campista.

12.Relatório do Ministério dos Negócios da Fazenda de 1909. República Federativa dos Estados Unidos do Brazil. Outubro de 1910. Imprensa Oficial. Rio. Ministro Francisco Antonio de Salles

13. Relatório do Ministério dos Negócios da Fazenda de 1910 e 1911. República Federativa dos Estados Unidos do Brazil. Outubro de 1912. Imprensa Oficial. Rio. Ministro Francisco Antonio de Salles

14. Relatório do Ministério dos Negócios da Fazenda de 1913. República Federativa dos Estados Unidos do Brazil. Outubro de 1914. Imprensa Oficial. Rio. Ministro Rivadávia Corrêa.

15.Relatório do Ministério dos Negócios da Fazenda de 1914. República Federativa dos Estados Unidos do Brazil. Outubro de 1915. Imprensa Oficial. Rio. Ministro João Pandiá Callógeras

16.Relatório do Ministério dos Negócios da Fazenda de 1915. República Federativa dos Estados Unidos do Brazil. Outubro de 1916. Imprensa Oficial. Rio. Ministro João Pandiá Callógeras 


\section{BIBLIOGRAFIA}

ABREU, Marcelo de Paiva. Os funding loans brasileiros - 1898-1931. Revista de pesquisa e planejamento econômico | ppe | v.32 | n.3 | dez 2002. Págs. 515 a 541

ABREU, Yolanda Vieira de \& SILVA, Helke Hernandes Raposo. Ignácio Rangel e os ciclos de Kondratieff. Palmas. Tocantins. 2009.

ABRIL CULTURAL. Nosso Século, 1900-1910. São Paulo. 1980.

ADDE, Tiago Villac; IUDÍCIBUS, Sérgio de; RICARDINO FILHO, Álvaro Augusto \& MARTINS, Eliseu. A comissão das partidas dobradas de 1914 e a contabilidade pública brasileira. Revista de contabilidade financeira. vol.25. №.especial. São Paulo Sept./Dec. 2014.

ALMEIDA, Marcelina das Graças de. Morte, cultura, memória - múltiplas interseções: uma interpretação acerca dos cemitérios oitocentistas situados nas cidades do Porto e Belo Horizonte. Tese de Doutorado em História. Faculdade de Filosofia e Ciências Humanas da Universidade Federal de Minas Gerais. 2007

ALVAREZ, Marcos César, SALLA, Fernando \& SOUZA, Luís Antônio F. A sociedade e a lei: o código penal de 1890 e as novas tendências penais na primeira república. NEV-USP. Acessado em 4/5/2015.

Disponível em<http://www.nevusp.org/downloads/down113.pdf>

ANDRADE, Oswald de. Obras Completas. In: VII TEATRO. A morta Ato lírico em três quadros. O rei da vela Peça em três atos. O homem e o cavalo Espetáculo em nove quadros. São Paulo. Civilização Brasileira.1973

ASSIS, Machado. Obra completa de Machado de Assis. Rio de Janeiro. Nova Aguilar, Vol. III, 1994. 
AWAD, Zaira Rocha \& BRESSER PEREIRA, Luiz Carlos. Empresários, suas origens e as interpretações do Brasil. In: I Congresso Brasileiro de História Econômica e à II Conferência Internacional de História de Empresas. Unicamp, Campinas, 8-9 de setembro, 1993.

AZEVEDO, Célia Maria Marinho de. Onda negra, medo branco. São Paulo. Editora Paz e Terra. 1987.

BARRETO, Lima. Os bruzundangas. Manaus. Universidade da Amazônia/ Nead. Capítulo XX. 1917.

BASBAUM, Lêoncio. História sincera da república ( 1889 a 1930). $6^{\text {a }}$ Ed. São Paulo. Editora Alfa-Ômega. 1993

BELLO, José Maria. História da república. $6^{\mathrm{a}}$ ed. $1^{\mathrm{a}}$ reimpressão. Rio de Janeiro. Companhia Editora Nacional. 1972

BENJAMIN, Walter. Passagens. Belo Horizonte/São Paulo. Editora UFMG/ Imprensa Oficial do Estado de São Paulo, 2006.

BÍBLIA. Sagrada Escritura. Acessado em 17/09/2016.

Disponível em $<$ http://www.vatican.va/archive/bible/index_po.htm $>$

BOSI, Alfredo. História concisa da literatura brasileira. 34ª Ed. São Paulo. Editora Cultrix.1994.

BOYLE, Charles. Senhores coloniais (1850-1900). São Paulo. Abril Cultural/ Time Life. 1992

BRAUDEL, Fernand. O tempo do mundo. $1^{\text {a }}$ ed. São Paulo. In: Civilização material, economia e capitalismo séculos XV-XVIII. Martins Fontes. 1996

BULCÃO, Clovis. Os Guinle: a história de uma dinastia. Rio de Janeiro. Editora Intrínseca. 2015 
BURKE, Peter (Org). A escrita da história. São Paulo. Editora Unesp. 1992.

BURNS, Arthut Frank \& MITCHELL, Wesley Clair. Measuring Business Cycles. New York, New York: National Bureau of Economic Research, 1946.

CALÓGERAS, Pandiá. Formação histórica do Brasil. Rio de Janeiro. Companhia Editora Nacional. 1966.

CALÓGERAS, Pandiá. A política monetária no Brasil. Cia Editora Nacional. São Paulo. 1960

CAMARATE, Alfredo. (pseud. Alfredo Riancho). Por Montes e Vale. Belo Horizonte. Revista do Arquivo Público Mineiro., Ano XXXVI, 1985.

CAMPBELL, Joseph. O herói das mil faces. São Paulo. Editora Cultrix/ Pensamento. 1993

CARDOSO, Ciro Flamarion \& BRIGNOLI, Héctor Pérez. Os métodos da história. $6^{\mathrm{a}}$ ed. São Paulo. Graal. 2002

CARDOSO, Fernando Henrique. Empresário industrial e desenvolvimento econômico no Brasil. São Paulo. Difel. 1972

CARLYLE, Thomas. On History. In: Thomas Carlyle: selected writings. Harmondsworth: Penguin Books, 1986. Apud: ANDRADE, Débora El-Jaick. In: Escrita da história e política no século XIX: Thomas Carlyle e o culto aos heróis. História e Perspectivas, Uberlândia (35): 211-246, Jul.Dez.2006

CARNEIRO, Maria Cecilia Ribas \& SILVA, Hélio. Artur Bernardes. Rio de Janeiro. Editora Três. 1983

Delfim Moreira. Rio de Janeiro. Editora Três. 1983

Epitácio Pessoa. Rio de Janeiro. Editora Três. 1983 
CARNEIRO, Maria Cecilia Ribas \& SILVA, Hélio. Nilo Peçanha. Rio de Janeiro. Editora Três. 1983

Washington Luiz. Rio de Janeiro. Editora Três. 1983

CARONE, Edgar. A evolução industrial em São Paulo ( 1889-1930). São Paulo. Editora SENAC. 2001

A primeira república ( 1889-1930). São Paulo. Difel.1976.

A república nova ( 1930_1937). São Paulo. Difel. 1976.

A república velha. Volume 2. São Paulo. Difel. 1983.

A república velha: Evolução política. São Paulo. Difel. 1971.

O tenentismo. São Paulo. Difel. 1973

CARRIL, Juan A. Capelán. Nueve décadas de gloria. Montevideo: Estampas SRL Realizaciones, 1990. Apud: CABO, Alvaro Vicente do Os primórdios do futebol uruguaio: da English high school à celestial garra charrúa. In: Anais do XXVI Simpósio Nacional de História - ANPUH. São Paulo, julho 2011.

CARVALHO, Fernando Cardim de. Keynes, a instabilidade do capitalismo e a teoria dos ciclos econômicos. Rio de Janeiro. Instituto de Pesquisa e Planejamento Econômico. 1988. 18(3).

CARVALHO, José Murilo de. A formação das almas: o imaginário da República no Brasil. São Paulo. Companhia das Letras, 1990.

CARVALHO, Ney. O encilhamento: anatomia de uma bolha brasileira. Rio de Janeiro/ São Paulo. CNB/Bovespa. 2004 
CERVO, Amador \& BUENO, Clodoaldo. História da política exterior do Brasil. $2^{\mathrm{a}}$ Ed. Brasília. Editora UNB. 2002

CROUZET, Maurice. História geral das civilizações. São Paulo. Volume 15. A época contemporânea. O declínio da Europa. O mundo Soviético. Bertrand Brasil. 1996.

DALFRÉ, Liz Andréa. Outras narrativas da nacionalidade: o movimento do Contestado. Curitiba. Sociedade de amigos do museu paranaense. 2014.

DALL'ALBA, Felipe Camilo. Os três pilares do Código Civil de 1916: a família, a propriedade e o contrato. Acesso em 05/8/2016. Disponível em:

http://www.tex.pro.br/home/artigos/109-artigos-set-2004/5147-os-tres-pilares-docodigo-civil-de-1916-a-familia-a-propriedade-e-o-contrato

DARÓZ, Carlos. O Brasil na primeira guerra mundial: a longa travessia. São Paulo. Editora Contexto. 2016

DECCA, Edgar de. O colonialismo como a glória do império. In.: REIS FILHO, Daniel Aarão, FERREIRA, Jorge \& ZENHA, Celeste. O século XX - o tempo das certezas. Volume 1 Civilização Brasileira. 2000. São Paulo.

DENIS, Benoit. Literatura e engajamento: de Pascal a Sartre. Bauru. Edusc. 2002.

DEUTSCHER, Isaac. Stálin: uma biografia polític $a$. Editora Record. Rio. 2006.

DINIZ, Edinha. Chiquinha Gonzaga: uma história de vida. $8^{\mathrm{a}}$ ed. Rio de Janeiro. Rosa dos ventos.1984. Acessado em 17 de outubro de 2016

Disponível em < http://dx.doi.org/10.1590/1808-057x201412030>.

ELLIS JR，Alfredo. Evolução da economia paulista e suas causas. São Paulo.[19?]

FACULDADE LIVRE DE DIREITO DO RIO DE JANEIRO. Parecer ao projeto de Código Civil. In: Código civil brasileiro: trabalhos relativos à sua elaboração. Rio de Janeiro: Imprensa Nacional .vol. 2. Págs. 59-61. 1918 
FAUSTO, Boris. Estrutura de poder e economia ( 1889-1930). $8^{\mathrm{a}}$ ed. Rio de Janeiro. In.: História Geral da Civilização Brasileira. Tomo III. Volume 8. Bertrand Brasil. 2006 Sociedade e instituições ( 1889-1930). $8^{\mathrm{a}}$ ed. Rio de Janeiro. In.: História Geral da Civilização Brasileira. Tomo III. Volume 9. Bertrand Brasil. 2006

FERNANDES, Florestan. A revolução burguesa no Brasil. $6^{\mathrm{a}}$ ed. Rio de Janeiro. Editora Globo. 2006

FERREIRA, Jorge \& DELGADO, Lucilia de Almeida Neves. O Brasil republicano o tempo do liberalismo excludente.Rio de Janeiro. Editora Civilização Brasileira.2003

FILHO, Mário. O negro no futebol brasileiro. Rio de Janeiro: Ed. Civilização Brasileira S.A., 1964.

FILHO. Daniel Aarão Reis. As revoluções russas e o socialismo soviético. São Paulo. Editora UNESP. 2003

FILOMENO, Felipe Amin. A crise Baring e a crise do Encilhamento nos quadros da economia-mundo capitalista. Economia e Sociedade, Campinas, v. 19, n. 1 (38), p. 135-171, abr. 2010.

FLEMING, Fergus. O mundo das armas ( 1900-1925). São Paulo. Abril Cultural/ Time Life. 1992

FOLLIS, Fransérgio. Modernização urbana na Belle Epóque paulista. São Paulo. Editora Unesp. 2004

FONSECA, Hermes da. Mensagem apresentada ao Congresso Nacional na abertura da segunda sessão da oitava legislatura. Rio de Janeiro. 1913

FONSECA, Pedro Cezar Dutra. A controvérsia entre metalismo e papelismo e a gênese do desenvolvimentismo no brasil. In: Encontro da associação nacional de 
professores de economia. 2008. Acessado em 24 de outubro de 2016.Disponível em: 〈http://www.anpec.org.br/encontro2008/artigos/200807210827300-.pdf>

FREITAS FILHO, Almir Pita. A política de defesa permanente do café na década de 1920 e o Instituto de Fomento e Economia Agrícola do Estado do Rio de Janeiro (1926-1931): notas para uma história institucional. In: Anais do XXVI Simpósio Nacional de História - ANPUH. São Paulo, julho 2011

FURTADO, Celso. Formação econômica do Brasil. São Paulo. 25 a ed. Cia Editora Nacional. 1995

GALBRAITH, J.K. La crise économique de 1929. Apud: GAZIER, Bernard. A crise de 1929. L\&PM. Rio Grande do Sul.

GAULD, Charles A. Farquhar, o último titã. São Paulo. Editora da Cultura. 2006

GAZIER, Bernard. A crise de 1929. Rio Grande do Sul. L\&PM. 2010.

GOMES BARBOSA, Glaudionor. Imperialismo, Capitalismo e burguesia. Revisitando as contribuições teóricas de Joseph Schumpeter e Hannah Arendt. In: Colombia Internacional 70, julio a diciembre de 2009: 145-165. Acessado em 16 de outubro de 2016. Disponível em: < http://www.scielo.org.co/pdf/rci/n70/n70a07.pdf >

GRAHAM, Richard. Clientelismo e política no Brasil do século XIX. Rio de Janeiro. Editora UFRJ. 1997

GREMAUD, Amaury Patrick. Das controvérsias teóricas à política econômica: pensamento econômico e economia brasileira no segundo império e na primeira republica (1840-1930). Doutorado apresentado na Faculdade de Economia e Administração da USP. 1996.

GRIMAL, Pierre. Dicionário de mitologia grega e romana. $2^{\mathrm{a}}$ Ed. Rio de Janeiro. Editora Bertrand Brasil. 1993 
HARDMAN, Francisco Foot. Trem fantasma: a modernidade na selva. $1^{\text {a }}$ reimpressão. São Paulo. Companhia das Letras. 1991.

HERNANDEZ, Leila Leite. A África na sala de aula. São Paulo. Selo Negro Edições. 2005.

HILL, Christopher R. Olympic Politics. Inglaterra.Manchester University Press. 1996.

HOBSBAWM, Eric. A era dos extremos. São Paulo. Companhia das Letras. 1997

A era dos impérios (1875-1914). Rio de Janeiro. Paz e Terra.1988.

Rebeldes primitivos - estúdio sobre las formas arcaicas dos

movimentos sociales en los siglos XIX y XX . $3^{\text {a }}$ edição. Espanha. Editorial Ariel. 1983.

HOBSON, John Atkinson, A evolução do capitalismo moderno. São Paulo. Abril Cultural. 1982.

HOMEM, Maria Cecília Naclério. Antônio da Silva Prado, prefeito da cidade de São Paulo: 1899-1910. In: Laboratório de Fundamentos da Arquitetura e do Urbanismo. FAU-USP. V Seminário de História da Cidade e do Urbanismo. "Cidades: temporalidades em confronto". Uma perspectiva comparada da história da cidade, do projeto urbanístico e da forma urbana. PUC-SP. 1998. Disponível em:

〈http://www.revistas.usp.br/rfdusp/article/viewFile/67220/69830>

KOTHE, Flávio \& SANTOS, Rita. Questionamento estético e sócioeconômico em o rei da vela. Acesso em 22 de agosto de 2016. Disponível em: <https://periodicos.ufsc.br/index.php/travessia/article/viewFile/18092/17009>.

LACERDA, Antônio Corrêa et alii. Economia brasileira. $4^{\text {a }}$ Ed. São Paulo. Saraiva. 2010 
LEAL, Victor Nunes. Coronelismo, enxada e voto. São Paulo. Editora Alfa-ômega. 1976

LÊNIN, Vladimir Ilicht. O desenvolvimento do capitalismo na Rússia. São Paulo. Editora Abril. 1982

Sobre a fome. Escrito: a 22 de maio de 1918. Primeira Edição: Pravda, ${ }^{\circ} 101$, de 24 de Maio de 1918. Fonte: Obras Escolhidas em Três Tomos, 1978, t2, p 618-623, Edições Avante! - Lisboa, Edições Progresso - Moscovo. HTML: Fernando A. S. Araújo, março 2009.

Imperialismo, fase superior do capitalismo. Arquivo Marxista na Internet. Acessado em 02/07/2009 (Original extraído do Editorial Avante/Progresso de Lisboa/Moscou. 1984). Disponível em;

<www.marxists.org/portugues/lenin/1916/imperialismo/index.htm>.

Resolução Sobre a Questão Agrária. 13 de Maio (30 de Abril) de 1917. Fonte: Obras Escolhidas em Três Tomos, 1977, tomo 2, pág: 86 a 88. Edições Avante! Lisboa, Edições Progresso - Moscovo. Tradução: Edições "Avante!" com base nas Obras Completas de V. I. Lénine, 5. ${ }^{a}$ ed. em russo, t. 31, pp. 425-428. Transcrição e HTML: Fernando A. S. Araújo

LÉRIAS, Reinéro Antônio. O Governo provisório e o encilhamento : história, historiografia e o caso da cidade de São Paulo. Doutorado. USP. São Paulo, 1998.

LEVY, Maria Barbara \& SAES, Flávio Azevedo Marques. Dívida externa brasileira, 1850-1913: empréstimos públicos e privados. Revista de História Econômica \& História de Empresas IV, I (2001 , 49-81).

LIMA, Heitor Ferreira. História do pensamento econômico no Brasil. São Paulo. Brasiliana. Volume 360. 1976.

Política econômica e industrial do Brasil. Cia Editora Nacional. São Paulo. 
LISBOA, José da Silva. ( Visconde de Cairu). Observações sobre a franqueza da indústria, e estabelecimento de fábricas no Brasil. Brasília. Senado federal. Coleção Biblioteca Básica Brasileira. 1999.

LOBATO, Monteiro. Paranoia ou mistificação? O Estado de S.Paulo. 20 de Dezembro de 1917. (A Propósito da Exposição Malfatti) [pág. ?]

LOBO, Helio. Docas de Santos: Suas Origens, Lutas e Realizações. Rio de Janeiro. Typ. do Jornal do Commercio Rodrigues. 1936

LOPES, João do Carmo \& ROSSETTI, José Paschoal. Economia monetária. 9a Ed. Revista, ampliada e atualizada. Editora Atlas. São Paulo. 2009.

LOPREATO, Cristina da Silva Roquette. O espírito da revolta. Tese de Doutorado defendida no Departamento de História do IFCH. Unicamp - SP. 1996. Orientador: Edgar S.de Decca.

LOPEZ, Adriana \& MOTA,Carlos Guilherme. História do Brasil: uma interpretação. São Paulo. Editora Senac. 2008.

LUZ, Nícia Vilela. A luta pela industrialização do Brasil. $2^{\mathrm{a}}$ ed. São Paulo. Editora Alfa-Ômega. 1978

MAGALDI, Sábato. Panorama do Teatro Brasileiro. São Paulo, Difusão Européia do Livro, 1962,

MANDEL, Ernest. O capitalismo tardio. Editora Abril. São Paulo. 1982.

MANKIW, N.Gregory. Introdução à economia. $6^{\text {a }}$ Ed. São Paulo. Cengage Learning. 2014

Princípios de macroeconomia. $6^{\text {a }}$ Ed. São Paulo. Cengage Learning. 2015

Princípios de microeconomia. 6ª Ed. São Paulo. Cengage Learning. 2015 
MARANHÃO, Ricardo \& SZMRECSÁNYI. Tamás. História de empresas e desenvolvimento econômico. $2^{a}$ ed. Edusp. Hucitec. São Paulo. Associação Brasileira de Pesquisadores em História Econômica. 2002

MARCOVITCH, Jacques. Pioneiros e empreendedores: a saga do desenvolvimento no Brasil. Volume 3. São Paulo. Edusp . Editora Saraiva. 2007

MARQUES, Rosa Maria \& REGO, José Marcio. (Orgs.). História econômica do Brasil. $2^{a}$ ed. São Paulo Saraiva. 2011

MARTINS-COSTA, Judith. A boa-fé no direito privado: sistema e tópica no direito obrigacional. 2. tir. São Paulo: Revista dos Tribunais, 2000.

MARX, Karl \& ENGELS, Friederich. O manifesto comunista. São Paulo. Instituto José Luis e Rosa Sundermann. 2003.

MARX, Karl. Para a Crítica da Economia Política. São Paulo. Coleção Os Economistas. Editora Abril. 1982.

MARX, Karl. O 18 brumário de Napoleão Bonaparte. $4^{a}$ ed. São Paulo. Nova Cultural. Coleção 'Os Pensadores'. 1988

MELVILLE, Herman. Moby Dick. São Paulo. Nova Cultural/ Círculo do Livro. 1994.

MILANI, Martinho Camargo. Estado Livre do Congo: Imperialismo, a Roedura Geopolítica (1885-1908). Dissertação de Mestrado. Faculdade de Filosofia, Letras e Ciências Humanas-USP. Departamento de História. 2011. Orientador: Prof.Dr. Lincoln Secco.

MOREIRA ALVES, José Carlos. Panorama do direito civil brasileiro: das origens aos dias atuais. Revista da faculdade de direito da universidade de São Paulo n 88 (1993) PP 185-238. Acesso em 31/07/2016. Disponível em:

$<$ http://www.revistas.usp.br/rfdusp/article/view/67220> 
MURTINHO, Joaquim. Relatorio apresentado ao presidente da republica dos estados unidos do Brasil pelo ministro do estado dos negocios da industria, viação e obras. Rio de Janeiro. Imprensa Nacional. 1897.

NOLETO, Mauro Almeida. Memória jurisprudencial-ministro Epitacio Pessôa. Brasilia. Gráfica do STF. 2009.

PALAZZO, Carmen Lícia. Dívida externa: a negociação de 1898. Brasília. Casa da Anta Editora. 1998.

PEÇANHA, Nilo. Mensagem apresentada ao congresso nacional na abertura da segunda sessão da setima legislatura. Rio de Janeiro. 1910

PINHO, Diva Benevides \& VASCONCELOS, Marco Antonio. Manual de Economia.

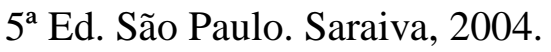

PIKETTY, Thomas. O capital no século XXI, São Paulo. Intrínseca. 2013

PRADO JR, Caio. História econômica do Brasil. 40ª ed. São Paulo. Brasiliense.1993 A revolução brasileira. $7^{\mathrm{a}}$ ed. São Paulo.Brasiliense. 1987

PRADO, Luiz Carlos Delome. A economia política das reformas econômicas da primeira década da República. Mimeo. 2001.

REMARQUE, Erich Maria. Nada de novo no front. Porto Alegre. L\&PM Editora. 2005

RIBEIRO, Darci. Os índios e a civilização. $3^{a}$ ed. Rio. Petrópolis: Vozes. 1982.

RIBEIRO, Fernando A política econômica e o convênio de Taubaté na economia cafeeira (1889-1906). Pesquisa \& Debate, SP, volume 22, número 1 (39) pp. 75-93, 2011 
RIBEIRO, Marília Andrés. O modernismo brasileiro: arte e política. Uberlândia ArtCultura, , v. 9, n. 14, p. 115-125, jan.-jun. 2007

SAID, Edward. Cultura e imperialismo. $2^{\text {a }}$ Reimpressão. São Paulo. Cia das Letras. 2005.

SAlguEIRO, Heliana Angotti. O Pensamento Francês na Fundação de Belo Horizonte: Das Representações às Práticas. In.: SALGUEIRO, Heliana Angotti. (org.) Cidades Capitais do Século XIX Racionalidade, Cosmopolitismo e Transferência de Modelos. São Paulo: Editora da Universidade de São Paulo, 2001

SALVADOR, Frei Vicente de. História do Brasil ( 1500-1627). São Paulo.7 ${ }^{\mathrm{a}}$ ed. Editora Itatiaia/ Editora da Universidade de São Paulo. 1982

SANTOS, João Manuel Casquinha Malaia. A revolução vascaína: a profissionalização do futebol e a inserção socioeconômica de negros e portugueses na cidade do Rio de Janeiro. FFLCH. História Econômica. Doutorado. 2010

O monopólio nos esportes: uma comparação da organização dos esportes comercializáveis nos Estados Unidos, na Inglaterra e no Brasil (1870-1920). Revista de História econômica \& História das empresas . v. 15, n. 2 (2012)

SCHUMPETER, Joseph A. History of economic analysis. Nova York. Oxford University Press. 1961.

Historia da Análise Econômica (volume 1). Rio de Janeiro. Editora Fundo de Cultura. Brasil/ Portugal. 1964

Historia da Análise Econômica (volume 2). Rio de Janeiro. Editora Fundo de Cultura. Brasil/ Portugal. 1964

. Historia da Análise Econômica (volume 3). Rio de Janeiro. Editora Fundo de Cultura. Brasil/ Portugal. 1964 
SCHWARCZ, Lilia M. \& STARLING, Heloisa M. Brasil: uma biografia. São Paulo. Companhia das Letras. 2015.

SCHWARZ, Robert. Um mestre na periferia do capitalismo. $2^{\text {a }}$ Ed. São Paulo. Editora Duas Cidades. 1990

SERGE, Victor. O ano I da revolução russa. Editora Boitempo. São Paulo. 2007.

SEVCENKO, Nicolau. O prelúdio republicano, astúcias da ordem e ilusões do progresso. In: SEVCENKO, Nicolau. História da vida privada no Brasil. Volume 3. Cia das Letras. São Paulo. 1998.

. Orfeu extático. São Paulo. Companhia das Letras. 1999

SILVA, Hélio. Afonso Pena. Rio. Editora Três. 1983.

. Campos Sales. Rio. Editora Três. 1983.

. Hermes da Fonseca. Rio. Editora Três. 1983.

Prudente de Moraes. Rio. Editora Três. 1983.

. Rodrigues Alves. Rio. Editora Três. 1983.

Wenceslau Brás. Rio. Editora Três. 1983.

SILVA, Izabel Pimentel. Pinheiro Machado. Verbete. CP DOC. FGV. Acessado em 01/09/2016. Disponível em: <http://cpdoc.fgv.br/sites/default/files/verbetes/primeirarepublica/MACHADO,\%20Pinheiro.pdf> .

SILVA, Sérgio \& SZMRECSÁNYI. Tamás. História econômica da primeira república. $2^{\mathrm{a}}$ ed. Edusp. Hucitec. São Paulo. Associação Brasileira de Pesquisadores em História Econômica. 2002 
SOUZA REIS, F.T.. Funding loan de 1931. Rio de Janeiro. Typograffia do Jornal do commercio. Rodrigues \& c. de 1934.

SOUZA, Márcio. Mad Maria. Círculo do Livro. São Paulo. 1980.

STEINBECK, JOHN. As vinhas da ira. 10ª Ed. Editora Record. Rio de Janeiro. 2012.

SUZIGAN, Wilson. Indústria brasileira - origem e desenvolvimento. São Paulo. Brasiliense. 1986.

SZMRECSÁNYI. Tamás \& COELHO, Francisco da Silva (org.). Ensaios de história do pensamento econômico no Brasil contemporâneo. São Paulo. Editora Atlas/ Ordem dos Economistas Brasileiros. 2007.

SZMRECSÁNYI. Tamás \& SUZIGAN, Wilson. História econômica do Brasil contemporâneo. $2^{\text {a }}$ ed. São Paulo. Edusp. Hucitec. Associação Brasileira de Pesquisadores em História Econômica. 2002

SZMRECSÁNYI, Tamás. História econômica da Primeira República. São Paulo. Fapesp.Hucitec. 1996.

TAUNAY, Affonso de E. Historia do café no Brasil. Rio de Janeiro. Volume nono: no Brasil República, 1889-1906 (Tomo I). Departamento nacional do café.1939

TAUNAY, Visconde de. O encilhamento. $4^{\text {a }}$ Ed. São Paulo. Melhoramentos.1972.

TOLSTOI, Leon. Guerra e Paz. São Paulo. Cosac-Naify. 2009.

TRINDADE, Alexandre Dias. André Rebouças: da engenharia civil à engenharia social. Campinas. Unicamp. IFCH. Doutorado em Sociologia. 2004

VARGAS, Getúlio. A nova política do Brasil. Volume V. Rio de Janeiro. José Olympio Editora, 1938. 
VERSIANI, Flávio Roberto. Escravos, homens livres e imigrantes: notas sobre a oferta de trabalho para a indústria no período até 1920. In: SILVA, Sérgio \&

VIEIRA, Dorival Teixeira. Evolução do sistema monetário brasileiro. Reimpressão da Edição de 1962. São Paulo. Instituto de Pesquisas Econômicas.1981

WILMOTT. H.P. Primeira guerra mundial. São Paulo. Editora Nova Fronteira. 2008.

WOLKMER, Antonio Carlos. História do direito no Brasil. Rio de Janeiro: Forense, 1999. In: DALL’ALBA, Felipe Camilo. Os 3 pilares do código civil de 1916 